UNIVERSIDADE DE SÃO PAULO

FACULDADE DE FILOSOFIA, LETRAS E CIÊNCIAS HUMANAS

DEPARTAMENTO DE LETRAS CLÁSSICAS E VERNÁCULAS

PROGRAMA DE PÓS-GRADUAÇÃO EM FILOLOGIA E LÍNGUA PORTUGUESA

Andréa Gomes de Alencar

\title{
O GÊNERO DEBATE NOS LIVROS DIDÁTICOS DE PORTUGUÊS DO ENSINO MÉDIO: VOZES EM DIÁLOGO
}

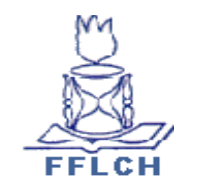

São Paulo

2017 
UNIVERSIDADE DE SÃO PAULO

FACULDADE DE FILOSOFIA, LETRAS E CIÊNCIAS HUMANAS

DEPARTAMENTO DE LETRAS CLÁSSICAS E VERNÁCULAS

PROGRAMA DE PÓS-GRADUAÇÃO EM FILOLOGIA E LÍNGUA PORTUGUESA

\section{O GÊNERO DEBATE NOS LIVROS DIDÁTICOS DE PORTUGUÊS DO ENSINO MÉDIO: VOZES EM DIÁLOGO}

Tese apresentada ao Programa de Pós-Graduação em Filologia e Língua Portuguesa, do Departamento de Letras Clássicas e Vernáculas da Faculdade de Filosofia, Letras e Ciências Humanas da Universidade de São Paulo, como requisito para obtenção do título de doutora em Letras, sob a orientação da Prof. a Dra. Maria Inês Batista Campos.

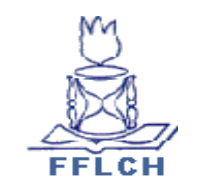

São Paulo 
Autorizo a reprodução e divulgação total ou parcial deste trabalho, por qualquer meio convencional ou eletrônico, para fins de estudo e pesquisa, desde que citada a fonte.

\section{Catalogação na Publicação \\ Serviço de Biblioteca e Documentação \\ Faculdade de Filosofia, Letras e Ciências Humanas da Universidade de São Paulo}

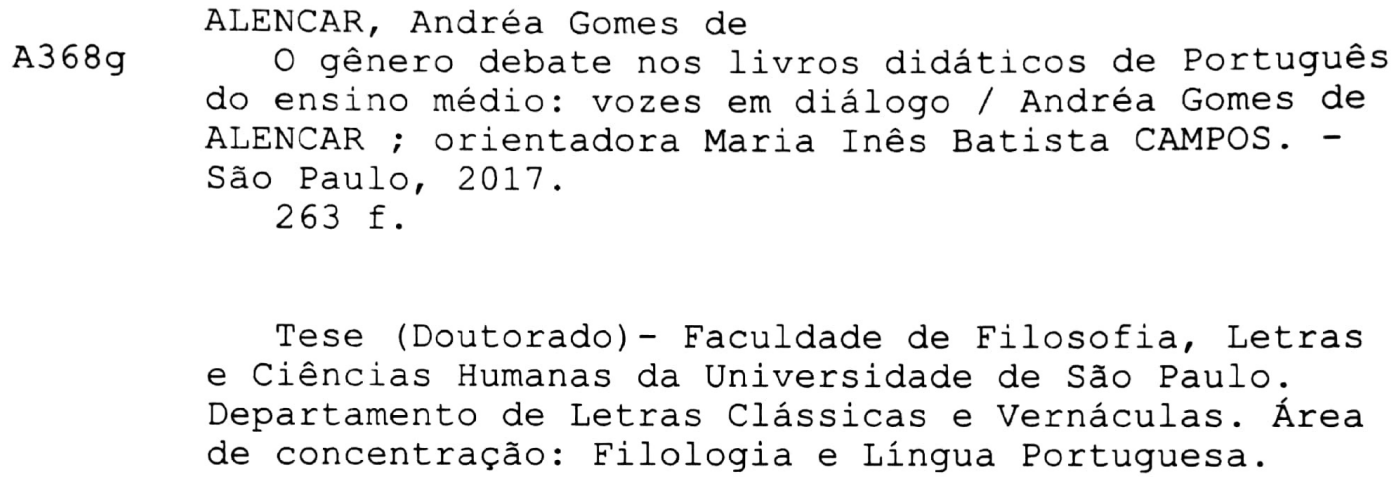


ALENCAR, Andréa Gomes de. O gênero debate nos livros didáticos de português do ensino médio: vozes em diálogo.

Tese apresentada ao Programa de Pós-Graduação em Filologia e Língua Portuguesa, do Departamento de Letras Clássicas e Vernáculas da Faculdade de Filosofia, Letras e Ciências Humanas da Universidade de São Paulo, como requisito para obtenção do título de doutora em Letras, sob a orientação da Prof. a Dra. Maria Inês Batista Campos.

Aprovada em:

BANCA EXAMINADORA

Prof. ${ }^{\text {a }}$ Dra. Maria Inês Batista Campos Instituição: Universidade de São Paulo Julgamento: Assinatura:

Prof. Instituição:

Julgamento:

Assinatura:

Prof.

Instituição:

Julgamento:

Assinatura:

Prof.

Instituição:

Julgamento:

Assinatura:

Prof.

Instituição:

Julgamento:

Assinatura: 
Aos meus pais, Edith e Moisés, eternos exemplos que me constituem.

Ao meu marido Renato, grandeapoiador de meus estudos.

À Lisandra, filha-amiga, amor iluminado que me motiva a seguir. 


\section{AGRADECIMENTOS}

O passado em mim vive. $O$ presente em mim transborda. $O$ futuro em mim reside. Agradeço a todos que contribuíram com minha caminhada!

\section{Aos meus protetores}

A Deus, por sua força extrema que habita dentro de mim, por me guiar nessa jornada e por me permitir esse momento de crescimento em mais essa existência.

Aos amigos espirituais, cuja presença amorosa foi sentida em tantos momentos da produção escrita e mesmo durante o sono de meu corpo físico.

\section{Aos familiares}

À minha mãe Edith, pelas orações, palavras fraternas e confiança em mim.

Ao meu pai Moisés, pelo estímulo e apoio constantes nessa trajetória.

Ao meu marido Renato, que compreendeu minha necessidade de diminuir minhas horas de trabalho para me dedicar à pesquisa e assumiu para si responsabilidades financeiras que me deram a tranquilidade para estudar.

À minha irmã Raquel, que assumiu um papel de "mãe" da Lili em diversos momentos - nas férias e em finais de semana - levando minha filha para passear e se distrair, fazendo com que ela sentisse um pouco menos a minha ausência.

Aos meus irmãos, André e Eurípedes, minhas cunhadas Marina e Roseli, meu ex-cunhado, Adriano, e meu atual cunhado Edilson, por toda torcida e apoio.

Aos meus sobrinhos queridos, que alegram a minha vida, dando um colorido a mais no meu viver: Letícia, Camila, Pedro, Caio, Sarah, Raíssa, Arthur e Esther.

A todos os familiares de São Paulo, pelo interesse carinhoso no decorrer desses cinco anos: Maria Helena, Débora, Paulo, Fátima, Denise e Adriano.

Aos meus queridos primos de Ribeirão Preto, que compreenderam as tantas vezes em que eu não pude estar com eles e me receberam com todo amor quando eu pude estar: Ivete, Arlete, Maria Cecília ("Tatá"), Hélio, Aline, Marcus, Saulo.

À tia Margarida e ao tio "Tunim" (in memoriam), cujas presenças sempre foram significativas na minha vida. 


\section{Aos mestres-exemplo}

À minha orientadora, Prof. a Dra. Maria Inês Batista Campos, pelos questionamentos pontuais que impulsionaram minhas descobertas e me fizeram superar meus próprios obstáculos.

Aos professores do Programa de Pós Graduação em Filologia e Língua Portuguesa (DLCV-USP) que me ajudaram, nas reflexões de nossas aulas, a construir meu perfil de pesquisadora: Prof. Dr. Manoel Luiz Gonçalves Corrêa, Prof. Dr. Luiz Antônio da Silva, Prof. ${ }^{a}$ Dra. Zilda Gaspar Oliveira de Aquino, Prof. ${ }^{\text {a }}$ Dra. Maria Inês Batista Campos.

Ao Prof. Dr. Geraldo Tadeu Souza (UFSCar), pela presença amiga e pelas trocas enriquecedoras nos nossos encontros do grupo de pesquisa e nas aulas ministradas na FFLCH.

À Prof. a Dra. Ana Zandwais (UFRGS-RS), por suas valiosas sugestões no início do desenvolvimento dessa pesquisa.

Ao Prof. Dr. João Gomes da Silva Neto, ao Prof. Dr. LuísPasseggi, à Prof.a Dra. Maria das Graças Soares Rodriguese à Prof. a Dra. Maria da Penha Casado Alves, pelas interlocuções significativas à época do intercâmbio entre universidades (USP/ PUC/UFRN) no âmbito do Programa de Colaboração Acadêmica (PROCAD), sediado na Universidade Federal do Rio Grande do Norte (UFRN) em 2013.

Aos professores que me ajudaram a repensar os caminhos dessa pesquisa por ocasião do exame de qualificação: Prof. Dr. Geraldo Tadeu Souza (UFSCar), Prof. . Dra. Zilda Gaspar Oliveira de Aquino (USP).

Às professoras que acompanharam meu início de pesquisadora, marcando presença não apenas na orientação dos trabalhos, mas especialmente no incentivo constante para meu progresso: Prof. ${ }^{a}$ Dra. Inez Sautchuk (TCC da graduação) e Prof. ․ Dra. Roxane Helena Rodrigues Rojo (dissertação de mestrado).

Aos professores que contribuíram com minha formação inicial na escola pública: no "primeiro grau" (atual Ensino Fundamental) e no "segundo grau magistério" (hoje extinto, mas equivalente ao Ensino Médio Profissionalizante).

Aos queridos professores da graduação em Letras da Universidade Presbiteriana Mackenzie: Turma Mack - Formandos de 2000! 


\section{Aos parceiros e amigos de caminhada}

À "tiaAlíria", amiga e "secretária do lar", que não só cuidou da minha casa para que eu tivesse tempo para estudar, como também cuidou de mim, trazendo lanches e suquinhos em meu escritório, quando eu me isolava para a escrita.

Aos amigos do grupo de pesquisa da USP, em especial à NatháliaPolachini, Elaine Hernandez, Débora Ribeiro, Denísia Moraes, Agildo Oliveira, Rita Bentes e CristianeBurlamaqui, com quem compartilhei momentos de alegrias e ansiedades, comuns à vida acadêmica.

Às minhas colegas do grupo de pesquisa, Denísia Moraes e Débora Ribeiro, e aos meus alunos Mara Tavares, Júlio César Araújo, Clayton Santos, Sandra Caldas e Edilian Arraes, que se empenharam em me ajudar a reunir todos os livros didáticos de português aprovados no PNLD 2015, analisados nessa pesquisa.

Ao Prof. Dr. Adail Sobral, que prontamente acolheu o meu pedido para realização do Abstract.

Aos professores do Centro Universitário Ítalo Brasileiro, na pessoa dos meus colegas Evaldo Bispo, Sueli Pitta, Cristiane Tolmar, Marcos Sagatio, Cátia Rodrigues, Edna Blumenschein, Rose Carreira e Luiz Felippe que sempre buscaram oferecer uma palavra amiga de estímulo e apoio para a continuação dessa jornada.

Ao Marcelo CizaurreGuirau, pelo encorajamento constante na minha vida acadêmica, por sempre acreditar em mim e pelo estímulo incondicional.

À Regina Braz Rocha, cujas interlocuções sempre foram significativas para minhas reflexões na pesquisa.

Ao querido Thiago Jorge Ferreira Santos, com quem convivi por ocasião dos dois cursos de extensão universitária ministrados na parceria USP-Escola, no Instituto de Física da USP, e que abracei como parceiro por toda vida.

Às minhas "irmãs eleitas" Jordana Thadei, Laura de Figueiredo, Marianka Santa Bárbara e Célia Araes, colegas de outros tempos, no mestrado, parceiras de diversos trabalhos profissionais e, acima de tudo, amigas valiosas que marcaram presença durante todo o processo de constituição da tese.

À Rosana Sanford, que sempre me enviou, de longe, suas boas vibrações e que me encorajou em vários momentos da caminhada. 
Às queridas Lucimara Vicente, Caroline Kono e Tatiana Camargo, que sempre torceram por meu sucesso e que compreenderam os muitos "nãos" quando me convidavam para um encontro fraterno.

Às amigas da turma Mack, que compartilham comigo o amor pela docência $\mathrm{e}$ estão sempre prontas a oferecer um estímulo amigo.

À família SEPEJ - Sociedade Espírita Pequeninos de Jesus - cuja presença carinhosa foi sempre um estímulo neste meu caminhar.

Aos meus alunos do curso de Letras, com quem compartilhei ideias e reflexões significativas sobre o que aprendia no doutorado e que são a razão maior por eu estar em constante busca pelo aprimoramento profissional.

\section{À Faculdade de Filosofia, Letras e Ciências Humanas (FFLCH)}

Aos chefes de departamento do PPG em Filologia e Língua Portuguesa entre 2013 e 2017 - que autorizaram a liberação de verba para viagens a congressos: Prof. Silva,Prof. ${ }^{a}$ Dra. Sheila Vieira de Camargo Grillo, Prof. ${ }^{a}$ Dra. leda Maria Alves, Prof. Dr. Paulo Roberto Gonçalves Segundo.

À Rosely e à Vera, pelo apoio na secretaria de pós-graduação do DLCV.

A todos os funcionários que realizam de forma pontual e competente seu trabalho diário - na biblioteca, na secretaria, na limpeza, na segurança e em demais setores -, dando assim o suporte para o estudo de tantos pós-graduandos, como eu.

\section{À bênção que Deus colocou na minha vida}

À Lisandra, filha querida, que sempre me ouviu, me compreendeu,me encorajou e projetou sobre mim, ainda em 2013, início de desenvolvimento dessa pesquisa, um futuro de vitória: a "formatura" do doutorado. Seu desenho, feito aos 8 anos de idade e me entregue em uma almofada como presente de dia das mães, foi, por várias vezes, um acalanto e um incentivo para eu continuar minha jornada.

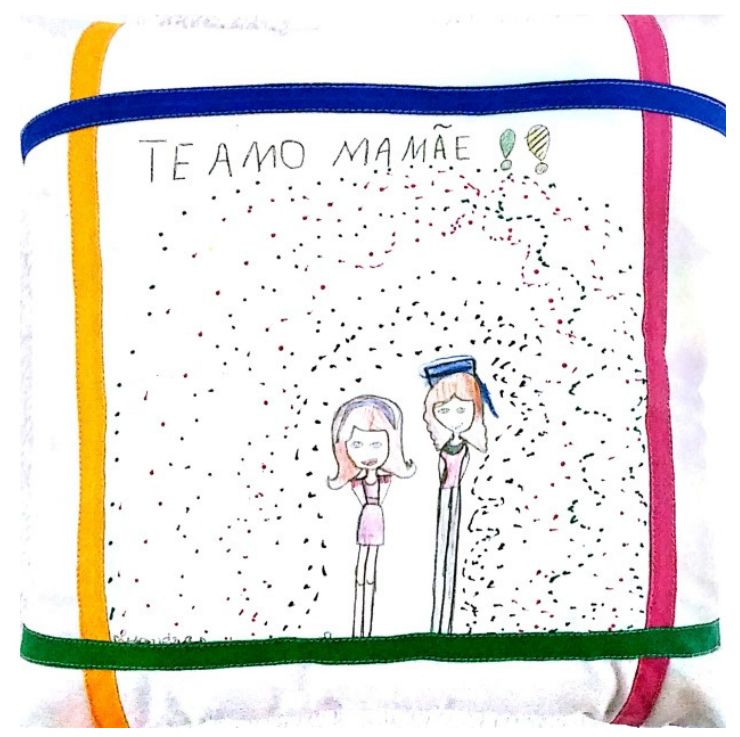


Há um tempo em que é preciso abandonar as roupas usadas que já têm a forma do nosso corpo... e esquecer os nossos caminhos que nos levam sempre aos mesmos lugares. É o tempo da travessia... e, se não ousarmos fazê-la, teremos ficado para sempre à margem de nós mesmos.

(Fernando Teixeira de Andrade Prof. de Literatura)

Sou feita de retalhos. Pedacinhos coloridos de cada vida que passa pela minha e que vou costurando na alma. Nem sempre bonitos, nem sempre felizes, mas me acrescentam e me fazem ser quem eu sou. Em cada encontro, em cada contato, vou ficando maior... Em cada retalho, uma vida, uma lição, um carinho, uma saudade... Que me tornam mais pessoa, mais humana, mais completa. 


\section{RESUMO}

ALENCAR. Andréa Gomes de. O gênero debate nos livros didáticos de Português do ensino médio: vozes em diálogo. 2017. 263p. Tese (Doutorado). Faculdade de Filosofia, Letras e Ciências Humanas, Universidade de São Paulo, USP/SP.

Nesse estudo, abordamos o livro didático de Português como um acontecimento, devido à importância de seu caráter singular como evento concreto, o que significaanalisá-lo na perspectiva do movimento dialógico. A partir da abordagem enunciativo-discursiva, este trabalho coloca em destaque o tratamento dado ao gênero debate nos livros didáticos de Português do ensino médio (LDP-EM), aprovados no Programa Nacional do Livro Didático (PNLD/2015).Com base na teoria dialógica do discurso, especialmente nos conceitos de interação verbal, enunciado concreto, gêneros do discurso e entonação expressiva, discutimos como o debate é proposto neste nível de ensino e comoasatividades práticas interferem no processo de desenvolvimento da oralidade do aluno para que ele assuma uma postura reflexiva. As perguntas de pesquisaque nortearam esta tese foram: (i) Como os documentos oficiais orientam as atividades dos livros didáticos de português do ensino médio?;(ii) Como o gênero debate foi apresentado nesses manuais?; (iii) Como se dá ou não o trabalho efetivo para tomada de posição dos sujeitos no processo da atividade argumentativa no ensino médio? A seleção do corpus deveu-se a dois critérios: (1) obras aprovadas no PNLD 2015, programa em nível nacional de avaliação de livros didáticos, cujos avaliadores são pesquisadores de instituições públicas - em sua maioria - de nível superior; (2) coleções mais distribuídas para as escolas públicas brasileiraspelo fundo nacional de desenvolvimento da educação (FNDE). A análise tomou como base quatro coleções, que perfazem $71 \%$ do total entregue em todo território nacional,paradiscutir as atividades que mobilizam o gênero debate, com os objetivos de: (i) estabelecer os diálogos que essas atividades constituem com documentos oficiais; (ii) identificar as propostas de debate apresentadas no LDP-EM, evidenciando o que é priorizado nesse ensino; (iii) investigar se os sujeitos são chamados a se posicionar criticamente, desenvolvendo seu ponto de vista e assumindo sua voz em situação de debate. Os resultados apontaram, prioritariamente, dois aspectos: (a)algumas coleções valorizama situação de ensino formal do gênero debate; (b) outras tomam esse conhecimento como pressuposto para propor situações de uso concreto do debate, apresentando, como norte a temática a ser desenvolvida. As práticas de oralidade do LDP-EM revelaram que há um diálogo tênue tanto com o Edital de Convocação do PNLD 2015, quanto com as Orientações Curriculares para o Ensino Médio- OCEM (BRASIL, 2006), corroborando as indicações apresentadas oficialmente. A maneira formal como algumas atividades são apresentadas e os temas nem sempre polêmicos propostos, no entanto, apontam para um apagamento da voz discente e indicam a necessidade de uma reflexão sobre o papel docente na condução do trabalho efetivo. Na arena de vozes entre os documentos oficiais (OCEM, Edital de Convocaçãoe Guia de livros didáticos do PNLD 2015 ensino médio português) e as quatro coleções analisadas,o livro didático de português torna-se umacontecimento singular e único. E nele o gênero debate se concretiza como um diálogo nem sempre aberto, algumas vezes pronto à reelaboração.

Palavras-chave: Livro didático de português. Ensino médio. PNLD 2015. Gêneros orais. Debate. 


\begin{abstract}
ALENCAR.Andréa Gomes de. The genre debate in High School Portuguese Language Textbooks: voices in dialogue. 2017. 263p.Thesis (Doctorate).School of Philosophy, Letters and Human Sciences, University of São Paulo, USP/SP.

In this study, we examine Portuguese language textbooks as an event, due to the importance of their singular character as concrete events, which means to analyze them from the perspective of a dialogical movement. Following the discursive-enunciative approach, this work emphasizes the way the genre debate is proposed in Portuguese language textbooks for High School (LDP-EM) approved by the National Program of Textbooks (PNLD/2015). Based on the dialogical theory of discourse, especially the concepts of verbal interaction, concrete utterance, speech genres and expressive intonation, we discuss how the genre debate is proposed in this teaching level and the way practical activities influence pupils' process of orality development so that they assume a reflexive posture. Our research questions were: (i) How do official documents direct activities for Portuguese language textbooks for High School? (ii) How is the genre debate presented in these manuals? (iii) How does effective work happens or not regarding subjects taking a position in the process of argumentative activities in High School? Data selection followed two criteria: (1) works had to be approved by PNLD 2015, a national level program for evaluation of textbooks whose evaluators are mostly Public Universities researchers; and (2) collections had to be the most used by Brazilian public schools by the National Fund for Education Development (FNDE). We analyzed four collections, which means $71 \%$ of the total distributed in the national territory, in order to discuss the activities that mobilize the genre debate, aiming at: (i) to identify the dialogues these activities may have with official documents; (ii) to identify the proposals for the genre debate presented in LDP-EM, showing up what is given priority in this teaching; (iii) to investigate whether subjects are called to assume a questioning position, developing their point of view and assuming their voice in debate situations. The results pointed essentially to two aspects: (a) some collections value the situation of formal teaching of the genre debate; (b) others take this knowledge as given for proposing situations of concrete use of the genre debate, focusing on themes to be developed. LDP-EM orality practices showed that there is a tenuous dialogue both with PNLD 2015 Call Notice and with the Curricular Guidelines for High School - OCEM (BRAZIL, 2006), corroborating the indications presented officially. The formal way some activities are presented and the themes not always controversial proposed, however, point to silencing pupil's voice and indicate the necessity of a reflection on the role of teachers in the development of the effective work. In the voices arena among official documents (OCEM, Call Noticeand Guide of Textbooks - PNLD 2015 Portuguese Language for High School) and the four collections analyzed, Portuguese language textbooks become a singular and only event. And in it the genre debate develops as a not always open dialogue, and sometimes ready to be re-elaborated.
\end{abstract}

Keywords: Portuguese language textbooks. High School.PNLD 2015.Oral genre. The genre debate 
Tabela 1 - Projeto NURC-SP - obras publicadas …………........................ 33

Tabela 2 - Gramática do Português Falado - obras publicadas …................. 37

Tabela 3 - Gramática do Português Culto Falado no Brasil - $1^{\underline{a}}$ fase ............. 39

Tabela 4 - Gramática do Português Culto Falado no Brasil - $2^{\mathrm{a}}$ fase ............. 40

Tabela 5 - Comparação das fases de publicação da coleção "Gramática do Português Culto Falado no Brasil" ............................................ 41

Tabela 6 - Aspectos a serem considerados no ensino do oral ....................... 54

Tabela 7 - Tratamento da oralidade no LDP: problemática .......................... 58

Tabela 8 - Relação área/disciplina/competência e habilidade -Ensino médio. 104

Tabela 9 - Oralidade no ensino médio - proposta das OCEM 110

Tabela 10 - Avaliação de livros didáticos de Português do ensino médio ....... 115

Tabela 11 - Prazos declarados no Edital de convocação do PNLD 2015....... 117

Tabela 12 - Relação dos avaliadores do PNLD 2015 ................................... 123

Tabela 13 - Relação da equipe responsável pelo PNLD 2015 ....................... 124

Tabela 14 - Síntese do anexo 2 do Guia do PNLD 2015 ............................. 130

Tabela 15 - Coleções que compõem o corpus da pesquisa ............................ 142

Tabela 16-Total de páginas das coleções (livro do aluno) ............................... 143

Tabela 17-Singularidades dos autores das coleções ................................... 144

Tabela 18- Organização estrutural da col.4-LPLI ......................................... 148

Tabela 19- Gêneros orais em quatro coleções do PNLD 2015 ...................... 150

Tabela 20- Orientação teórico-metodológica para análise ............................. 154

Tabela 21- Debate regrado público, no vol.1 - col.1-PL .............................. 158

Tabela 22- Organização capítulo debate regrado público - col.1-PL ............ 167

Tabela 23- Títulos da seção "E mais" - gênero "debate" - col.2-NP ............. 174

Tabela 24-Leituras para debate no capítulo 6 - col.2-NP ............................ 192

Tabela 25 - Possíveis temas para debate - col.2-NP .................................... 193

Tabela 26 -Presença do gênero "debate" em seções e boxes - col.3-PCIS . 198

Tabela 27 -Presença do gênero "debate" em seções da col.4-LPLI ............. 207 
Figura 1 - Continuum fala - escrita, sob o enfoque dos gêneros .................... 30

Figura 2 - Esquema de SD proposto pelos pesquisadores de Genebra ......... 65

Figura 3 - Relação entre enunciado e gênero do discurso ............................. 83

Figura 4 - Relação entre situação, auditório e entonação .............................. 91

Figura 5 - Ato: visão fragmentária e em sua totalidade ................................ 95

Figura 6 - Quadro esquemático de avaliação das coleções do PNLD 2015 ... 128

Figura 7 - Delimitação da pesquisa ...................................................... 135

Figura 8 - Divisão da obra por eixo de ensino: col. 2-NP ............................ 146

Figura 9 - Orientações para o planejamento do debate - col.1-PL-vol.3 ...... 170

Figura 10 - Proposta de debate (início) - col.2-NP ..................................... 175

Figura 11- Proposta de debate (continuação) - col.2-NP ............................ 176

Figura 12 -Boxe com orientação prévia ao debate - col.2-NP ..................... 182

Figura 13 -O debate e o momento de interação - col.2-NP .......................... 194

Figura 14 -Boxe "produção oral" - col.3-PCIS ........................................... 201 


\section{LISTA DE SIGLAS E ABREVIAÇÕES}

\begin{tabular}{|c|c|}
\hline cap. & Capítulo \\
\hline col. & Coleção \\
\hline DCNEM & Diretrizes Curriculares Nacionais para o Ensino Médio \\
\hline EM & Ensino Médio \\
\hline ENEM & Exame Nacional do Ensino Médio \\
\hline FNDE & Fundo Nacional de Desenvolvimento da Educação \\
\hline LD & Livro Didático \\
\hline LDBEN & Lei de Diretrizes e Bases da Educação Nacional \\
\hline LDP & Livro Didático de Português \\
\hline LDP-EM & Livro Didático de Português do Ensino Médio \\
\hline LPLI & Língua Portuguesa: Linguagem e interação \\
\hline MEC & Ministério da Educação e da Cultura \\
\hline NP & Novas Palavras \\
\hline NURC & Norma Urbana Culta \\
\hline OCEM & Orientações Curriculares para o Ensino Médio \\
\hline OED & Objetos Educacionais Digitais \\
\hline PCIS & Português, contexto, interlocução e sentido \\
\hline PCN & Parâmetros Curriculares Nacionais \\
\hline $\mathrm{PCN}+$ & Parâmetros Curriculares Nacionais Mais \\
\hline PCNEM & Parâmetros Curriculares Nacionais para o Ensino Médio \\
\hline $\mathrm{PL}$ & Português Linguagens \\
\hline PNLD & Programa Nacional do Livro Didático \\
\hline unid. & Unidade \\
\hline vol & Volume \\
\hline
\end{tabular}




\section{SUMÁRIO}

CAPÍTULO 1 - ORALIDADE: HISTÓRIA, CONSTITUIÇÃO E ENSINO ......... 25

1.1. Primeiras reflexões: teoria da grande divisa ....................................... 26

1.2. A inter-relação entre 0 oral e o escrito .............................................. 28

1.3. Oralidade sob a perspectiva interacional face a face ........................... 31

1.3.1. Projeto Nurc ....................................................................... 31

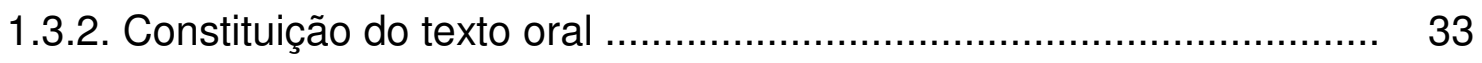

1.4. Oralidade sob a perspectiva gramatical .............................................. $\quad 37$

1.4.1.Projeto Gramática do Português culto falado no Brasil.................... $\quad 37$

1.4.2. Natureza da modalidade oral ................................................... 42

1.5. Reconhecimento oficial para o ensino da oralidade ............................. 46

1.6. Oralidade como objeto de ensino........................................................... 49

1.6.1. Recepção nas práticas de sala de aula ......................................... 51

1.6.2. Recepção nos Livros Didáticos de Português ................................... 57

CAPÍTULO 2 - ORALIDADE NA TEORIA DIALÓGICA DO DISCURSO ....... 67

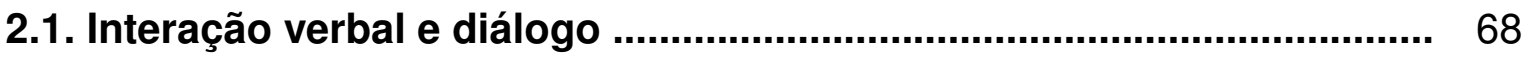

2.2. Enunciado concreto …......................................................................... 72

2.3. Constituição do sujeito no círculo bakhtiniano ................................... 77

2.4. Gêneros do discurso e esfera da comunicação social ........................ 80

2.5. Entonação expressiva e valoração da linguagem .............................. 89

2.6. Livro didático como acontecimento ................................................. 93

2.7.Unindo a ponta dos fios ...................................................................... 98 
CAPÍTULO 3 -A COMPOSIÇÃO DO LIVRO DIDÁTICO DE PORTUGUÊS DE ENSINO MÉDIO PARA O PNLD 2015 ................................................. 101

3.1. Esfera escolar: Ensino Médio em foco .............................................. 102

3.2. Caracterização do Ensino Médio: documentos oficiais reguladores 103

3.3. Programa Nacional do Livro Didático para o Ensino Médio ................ 110

3.3.1. Editalde convocação do PNLD 2015........................................... 116

3.3.2. Guia de livros didáticos: PNLD 2015 ensino médio português.......... 121

CAPÍTULO 4 -PERSPECTIVA TEÓRICO-METODOLÓGICA ....................... 133

4.1. Delimitação da pesquisa .................................................................. 134

4.2. Caracterização do gênero debate .................................................. 135

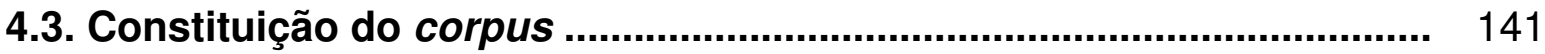

4.3.1. Descrição geral das obras....................................................... 143

4.3.2. Distribuição dos conteúdos de ensino nas coleções ....................... 145

4.3.3. Presença de gêneros orais na coletânea ...................................... 149

4.4. Percurso teórico-metodológico e categorias de análise ..................... 152

CAPÍTULO 5 - A PRESENÇA DO GÊNERO DEBATE NO LIVRO DIDÁTICO DE PORTUGUÊS DO ENSINO MÉDIO ....................................... 156

5.1. O debate como objeto de ensino em Português Linguagens .............. 157

5.2. O debate e o vínculo com a literatura em Novas palavras................... 173

5.3. O debate como prática social em Português, contexto, interlocução e sentido......................................................................................... 197

5.4. O debatecomo objeto de análise e reflexão em Língua Portuguesa: linguagem e interação.......................................................................... 205

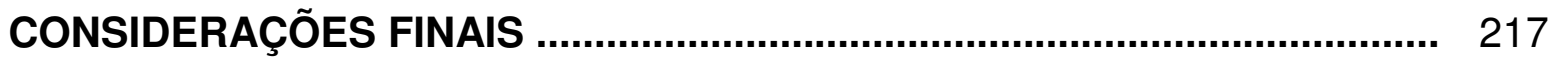

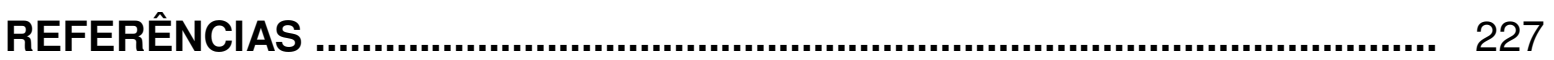


ANEXO 1 - Relação das obras aprovadas no PNLD 2015 ............................ 240

ANEXO 2 - Relação das obrasdo PNLD 2015 mais adquiridas pelo FNDE ... 241

ANEXO 3a - Gêneros orais em Português Linguagens - vol.1 ..................... 242

ANEXO 3b - Gêneros orais em Português Linguagens - vol.2 ..................... 244

ANEXO 3c - Gêneros orais em Português Linguagens - vol.3 ..................... 246

ANEXO 4a - Gêneros orais em Novas Palavras- vol.1 .............................. 248

ANEXO 4b - Gêneros orais em Novas Palavras- vol.2 .............................. 250

ANEXO 4c - Gêneros orais em Novas Palavras - vol.3 ................................ 252

ANEXO $5 a$ - Gêneros orais emPortuguês: contexto, interlocução e sentido -

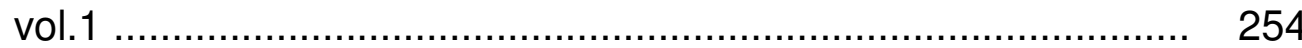

ANEXO 5b - Gêneros orais emPortuguês: contexto, interlocução e sentido vol.2

ANEXO 5c - Gêneros orais emPortuguês: contexto, interlocução e sentido vol.3.

258

ANEXO 6a - Gêneros orais em Língua Portuguesa: linguagem e interação vol.1

260

ANEXO 6b - Gêneros orais em Língua Portuguesa: linguagem e interação vol. 2

ANEXO 6c - Gêneros orais em Língua Portuguesa: linguagem e interação vol.3 


\title{
CONSIDERAÇÕES INICIAIS
}

\begin{abstract}
A palavra torna-se palavra somente no intercâmbio comunicativo social vivo, na enunciação real, que pode ser compreendida $e$ avaliada não somente pelo falante, mas também pelo seu auditório, seja este potencial ou realmente existente.
\end{abstract}

(VOLÓCHINOV, 2013c, p. 196)

A necessidade da instituição de um trabalho com gêneros orais no ensino de Língua Portuguesa não é mais um fato discutível. Observamos, especialmente a partir do final da década de 80 e no decorrer dos anos posteriores até os dias atuais ${ }^{1}$, não só a defesa do estudo da oralidade nos meios acadêmicos - a partir de pesquisas e publicações de obras ${ }^{2}$-, mas também uma posição assumida pelo Estado, através de documentos oficiais ( $\left.\mathrm{PCN}, \mathrm{PCN}+, \mathrm{OCEM}, \mathrm{PNLD}^{3}\right)$ que incluem

\footnotetext{
${ }^{1} \mathrm{O}$ ano de referência é 2017.

${ }^{2}$ Conferir, por exemplo: Fávero, Andrade e Aquino (2012, 2014); Marcuschi (2001, 2003 e 2010); Ramos (1997); Santos, Costa-Maciel e Barbosa (2012); Cavalcante e Melo (2006); Magalhães (2011).

${ }^{3}$ PCN - Parâmetros Curriculares Nacionais (BRASIL, 1997, 1998, 2000); PCN+ Ensino Médio Orientações Educacionais complementares aos Parâmetros Curriculares Nacionais (BRASIL, 2002); OCEM - Orientações Curriculares para o Ensino Médio (BRASIL, 2006); PNLD - Programa Nacional do Livro Didático (BRASIL, 2015).
} 
os gêneros orais como objeto de ensino. Tal fato, justifica-se pela necessidade de a escolaampliar o acesso do aluno às diversas formas de comunicação para seu uso efetivo nas práticas sociais e isto coloca em pé de igualdade tanto as práticas escritas, quanto às ligadas à comunicação oral.

Como decorrência dessa nova visão, em que a oralidade passa a ser consideradacomo objeto de ensino, algumas atividades ligadas ao desenvolvimento de gêneros orais passaram a integrar as propostas de algunslivros didáticos de Português ${ }^{4}$. A questão, então, passou a ser outra: o que se ensina nessas obras e como isso é feito?

Diversos estudos (COSTA, 2006; BARROS-MENDES, 2005; MAGALHÃES, 2007; TEIXEIRA, 2012; dentre outros) apontam a pouca valorização que o estudo de gêneros orais assumiu em obras didáticas dos diferentes níveis de ensino da educação básica, seja por não haver quantidade significativa de propostas no LDP se comparado aos demais eixos de ensino - seja por apresentarem atividades que funcionam ora como pretexto para outros ensinos, ora como uma prática pouco desenvolvida, que não permite ao aluno assumir sua própria voz.

Ensinar gêneros orais, no nosso entender, não é apenas expor o aluno a situações em que se faz necessário o uso do discurso oral. Mais que isso, é fundamental que ele compreenda que aspectos envolvem a interação, como são as relações entre os sujeitos, quais os jogos de poder envolvidos na situação e na esfera em que o discurso é produzido e, ainda, de que estratégias textuaisdiscursivas ele poderá lançar mão para atingir seus propósitos comunicativos, assumindo sua autoria enunciativa.

Considerando que é papel das aulas de Português contribuir para a formação cidadã do aluno, acreditamos ser necessária, no que se refere à produção oral do livro didático de Português, uma reflexão acerca de como o aluno é levado a posicionar-se frente ao dito, assumindo uma postura mais crítica e responsável no interior da prática discursiva.

\footnotetext{
${ }^{4}$ Doravante, LDP.
} 
Nessa pesquisa, focalizamos o gênero debate nos livros didáticos de Português deensino médio ${ }^{5}$, para compreender a arena de vozes nele presente e para investigar como as atividades propostas podem dar voz ao sujeito.

No decorrer de nosso estudo, procuramos responder as seguintes perguntas de pesquisa:

- Como os documentos oficiais orientam as atividades dos livros didáticos de português do ensino médio?

- Como o gênero debate foi apresentado nesses manuais?

- Como se dá ou não o trabalho efetivo para a tomada de posição dos sujeitos no processo da atividade argumentativa no ensino médio?

O objetivo geral deste estudo é compreender o ensino dos gêneros orais no LDP-EM, particularmente o debate, como texto que possibilita uma tomada de posição crítica e responsável de um sujeito, levando-o a assumir sua própria voz.

Para nortear nosso olhar, definimos os seguintesobjetivos específicos:

- Estabelecer os diálogos que essas atividades constituem com documentos oficiais.

- Identificar as propostas de debate apresentadas no LDP-EM, evidenciando o que é priorizado nesse ensino.

- Investigar se os sujeitos são chamados a se posicionar criticamente, desenvolvendo seu ponto de vista e assumindo sua voz em situação de debate.

O artigo 35 da $\operatorname{LDB}^{6}$ (Lei 9394/96) declara ser objetivo do ensino médio promover a formação ética e o desenvolvimento do pensamento crítico do discente, preparando-o para assumir sua postura cidadã nas diversas situações de participação social. Cabe à escola, portanto, não apenas explorar aspectos ligados ao conhecimento da língua e seu funcionamento, mas também propiciar reflexões sobre propostas realmente pertinentes para a formação integral do aluno, dando a este condições de se posicionar frente aos diversos enunciados a que tem acesso.

\footnotetext{
${ }^{5}$ Doravante, LDP-EM.

${ }^{6}$ Lei de Diretrizes e Bases da Educação Nacional.
} 
Art. 35. O ensino médio, etapa final da educação básica, com duração mínima de três anos, terá como finalidades:

I. a consolidação e o aprofundamento dos conhecimentos adquiridos no ensino fundamental, possibilitando o prosseguimento de estudos;

II. a preparação básica para o trabalho e a cidadania do educando, para continuar aprendendo, de modo a ser capaz de se adaptar com flexibilidade a novas condições de ocupação ou aperfeiçoamento posteriores;

III. o aprimoramento do educando como pessoa humana, incluindo a formação ética e o desenvolvimento da autonomia intelectual e do pensamento crítico;

IV. a compreensão dos fundamentos científico-tecnológicos dos processos produtivos, relacionando a teoria com a prática, no ensino de cada disciplina.

(BRASIL, 1996, p. 13-14, grifos nosso.)

Considerando que uma das habilidades necessárias para a formação do educando como cidadão autônomo é seu desenvolvimento em situações orais de comunicação social, entendemos que o recorte desta pesquisa acerca da presença dogênero debate no LDP-EM,justifica-se por três motivos:

(1) o livro didático de Português, devido ao Programa Nacional do Livro Didático ${ }^{7}$, instituído no ensino médio em âmbito nacional desde 2010, tem seu acesso garantido a milhões de estudantes das escolas brasileiras, constituindo-se, assim, um importante recurso didático;

(2) o ensino médio $^{8}$, que se tornou obrigatório apenas a partir de 2009, ainda possui um número de pesquisas menor no que se refere aos estudos da oralidade. Nossoestudo, então, pode contribuir para ampliar a discussão sobre o trabalho com gêneros orais no LDP, voltado para esse nível de ensino;

(3)a investigação sobre como o aluno é levado a se posicionar, desenvolvendo sua voz a partir das propostas de debate no LDP-EM pode contribuir para a formação de cidadãos mais conscientes de sua responsabilidade no interior das práticas discursivas, da escola e da vida.

\footnotetext{
${ }^{7}$ Doravante, PNLD.

${ }^{8}$ Doravante, EM.
} 
Tomamos como corpus de análiseas atividades do gênero debate presentes em quatro coleções de ensino médio aprovadas no PNLD-2015. A escolha das obras didáticas ocorreu por serem essas as que mais foram distribuídas pelo Fundo Nacional de Desenvolvimento da Educação - FNDE - nas escolas públicas, perfazendo um total de $71 \%$ dentre as obras entregues em todo território nacional.

Entendemos que o gênero debate no LDP-EM pode ser mais que uma tarefa dentre tantas solicitadas pela escola se for encarada como parte de um processo mais amplo em que valores são retomados / construídos a partir do embate de vozes, em um tempo socio-histórico que também precisa ser considerado. Dessa forma, nosso olhar para o corpus fundamenta-se em uma perspectiva enunciativodiscursiva, de base bakhtiniana.

Para conduzir nossa reflexão, no capítulo 1, apresentamos o percurso histórico dos estudos sobre oralidade, desde as primeiras concepções dicotômicas em relação à escrita, até uma visão menos excludente e mais imbricada dessas duas modalidades. Para tanto, retomamos pesquisas que tiveram papel importante nesse percurso, como os estudos do Projeto Nurc-SP e os que resultaram na publicação da Gramática do Português falado e a Gramática do Português culto falado no Brasil. Ainda neste capítulo, trazemos para discussão pesquisas já publicadas sobre a oralidade, mostrando como esses estudos têm sido pensados não só para a prática de ensino, mas também como objeto de estudo nos livros didáticos de português.

No capítulo 2, apontamos os principais subsídios teóricos que dão base ao nosso estudo, no interior de uma teoria dialógica do discurso, buscando evidenciar as discussões advindas das pesquisas de Bakhtin/Volóchinov/Medvedev. Trazemos, assim, conceitos relevantes do círculo bakhtiniano, como: interação verbal, diálogo, enunciado concreto, esfera de comunicação, gêneros do discurso, entonação e valoração da linguagem, que nos permitem chegar à concepção de livro didático como acontecimento.

No capítulo 3, retomamoso contexto mais amplo a que o livro didático de português de ensino médio está ligado. Para compreendê-lo, apresentamos, de um lado, as especificidades do EM, a partir dos documentos oficiais que regulam esse 
ensino, e, de outro, o que foi o PNLD 2015, o edital de convocação e o guia do livro didático de português.

No capítulo 4, delineamos os percursos metodológicos que guiaram nosso estudo, evidenciandonossa perspectiva de análise. Além disso, descrevemosas quatro coleções de Livros Didáticos de Português voltados para o ensino médio e aprovadas no PNLD-2015, para, em seguida, apresentar nosso recortee situar as atividades com o gênero debate propostas em seu interior. Por fim, evidenciamos nossas categorias de análise para posterior leitura do corpus.

No capítulo 5, nosso foco recai sobre a descrição e análise das atividades dedebate nasquatro coleções selecionadas, evidenciando tanto como esse gênero é proposto, quanto os diálogos que as atividades estabelecem com o Edital de convocação do PNLD 2015 e com as orientações curriculares para o ensino médio. Além disso, evidenciamos se/como a tomada de posição dos sujeitos se estabelece.

Para encerrar, nas considerações finais, retomamos as questões de pesquisa e apresentamos tanto os resultados desse estudo, quanto nossas reflexões acerca de possíveis caminhos que poderiam nortear o trabalho com o gênero debate no ensino médio, propiciando o desenvolvimento da voz autoral do sujeito em seu processo de formação como cidadão crítico e autônomo.

É, pois, na busca de um "intercâmbio comunicativo social vivo", em que a palavra possa ser "compreendida e avaliada", conforme apontou Volóchinov (2013c, p. 196), que situamos nossa pesquisa. 


\section{CAPÍTULO 1}

\section{ORALIDADE: HISTÓRIA, CONSTITUIÇÃO E ENSINO}

Mais do que reconstruir um tempo passado, talvez interesse salientar a influência na construção do novo que um texto do passado foi capaz de exercer.

(GERALDI, 2013, p. 18)

Qualquer estudo que se inicia não parte do zero e olhar para o passado pode ser produtivo, tanto para entender melhor o percurso que trilhamos hoje, como para reconhecer avanços e fragilidades que podem nos ajudar a refletir sobre as pesquisas desenvolvidas no presente.

Dessa forma, apresentamos nesse primeiro capítulo um percurso histórico do conceito de oralidade e sua relação com a escrita, desde a primeira metade do século $X X$ até a primeira quinzena do século $X X I$. Apontaremos, assim, as principais caracterizações deste conceito, além de como se deu suachegada nos espaços escolares e as orientações para seu ensino. 


\subsection{Primeiras reflexões: teoria da grande divisa}

Os estudos linguísticos contemporâneos - em especial, na primeira quinzena do século XXI - já reconhecem a necessidade daconstituição da oralidade enquanto objeto de estudo, seja nos meios acadêmicos, seja nas práticas desenvolvidas em escolas do ensino básico. Pode-se dizer, no entanto, que um longo caminho foi trilhado para que isso pudesse acontecer.

Na primeira metade do século $X X$, os estudos da linguagem centravam-se no sistema linguístico como tal, reforçando a valorização da escrita em detrimento da fala.Marcuschi (2008), tratando dessa época histórica, afirma que isso pode ser observado, por exemplo, a partir do desenvolvimento das pesquisas saussurianas.

O mestre genebrino concebia a língua como um fenômeno social, mas analisava-a como um código e um sistema de signos. A dar crédito aos ensinamentos contidos no Curso, interessavam-lhe apenas o sistema e a forma e não o aspecto de sua realização na fala ou no seu funcionamento em textos.

(MARCUSCHI, 2008, p. 27.)

Embora não fosse negada a existência da fala, não havia nessa época uma preocupação em estudá-la por ser considerada assistemática e individual.

Kerbrat-Orecchioni (1996/2006, p. 37), tratando da pouca importância que o oral assumiu nesse período, aponta que esse fato fica evidente quando se observa que "é em relação à escrita, admitida como norma, que foram geralmente efetuadas as descrições sintáticas; e que o oral espontâneo é ainda muito frequentemente considerado subproduto da linguagem". A autora explicita, por exemplo, como aspectos característicos do discurso oral (como gaguejos, balbucios, lapsos, frases inacabadas, repetições, reformulações, marcadores de hesitação, dentre outros) eram tratados pelos estudos formais daquela época como "falhas".

Segundo Haverlock (1995), a partir da década de 60, pesquisas que tinham como foco as relações entre a cultura oral e escrita, tratadas de forma sistemática, começaram a ser difundidas. Contribuiu para isso, conforme o autor, o fato de os meios de comunicação estarem passando por transformações naquele período.

Ong (1982/1998) também coloca os estudos de 1960 e 1970 como marco das pesquisas acerca das relações entre culturas orais e escritas. $O$ autor, no 
entanto, desenvolve uma tese que acaba por distanciar a oralidade da escrita. Para ele, a nossa capacidade de raciocínio formal estaria condicionada ao surgimento da escrita, conclusão que favoreceu o fortalecimento da crença da supremacia do escrito sobre o oral. Essa visão dicotômica pode ser observada, por exemplo, na introdução de seu trabalho, em que ele sinaliza para o objetivo central de sua obra: "o tema deste livro são as diferenças entre oralidade e cultura escrita." (ONG, 1982/1998. p. 9).

Para o autor, o pensamento oral é: (1) mais aditivo que subordinativo; (2) pouco analítico; (3) redundante e pouco original; (4) mais conversador e tradicional; (5) próximo das situações de vida; (6) mais emocional; (7) mais participativo; (8) mais equilibrado; (9) ligado ao contexto, que gera o significado; (10) mais concreto. (ONG, 1982/1998)

As ideias apresentadas pelo autor acabam por remeter para um divisor de águas, em que apenas a oralidade poderia ter as especificidades apontadas, o que sabemos não ser necessariamente verdade. Para exemplificar, tomemos o aspecto do "equilíbrio" (tópico 8). Para o autor, esta condição construir-se-ia pelo fato de o presente ser a base da organização das sociedades orais, e o passado, sem relevância efetiva, ser descartado para a manutenção desse equilíbrio. Entendemos, no entanto, que a relação presente-passado pode não apenas não prejudicar, mas até contribuir para o equilíbrio de uma dada sociedade, visto que as relações que se constroem nesse processo tendem, inclusive, a favorecer a interação do grupo.

Muitos estudos posteriores acabaram por se posicionar contra essa divisão estanque entre o oral e o escrito, uma vez que acabava por dar à escrita um lugar privilegiado, em detrimento dos aspectos da oralidade.

Marcuschi (2010, p.28), ao se referir à perspectiva dicotômica, que tem como foco a fala em oposição à escrita, afirma que "o inconveniente [dessa visão] é considerar a fala como o lugar do erro e do caos gramatical, tomando a escrita como o lugar da norma e do bom uso da língua".

Tal concepção é ainda observadaem nossa época - primeira quinzena do século XXI -, especialmente para o senso comum e mesmo para estudiosos de outras áreas científicas. 
A questão do oral como espaço do "erro" é tão evidente que Bagno (2011) dedica parte de sua obra - voltada à orientação pedagógica sobre o ensino de português - para dialogar sobre essa falsa concepção. Ou seja, em pleno século $\mathrm{XXI}$, ainda se faz necessário retomar a discussão de que a fala não é o lugar do erro.

Em sua obra, o autor apresenta as raízes históricas dessa problemática: a visão dos gramáticos alexandrinos que, ao imprimir um juízo de valor negativo sobre as mudanças linguísticas percebidas em sua época, acabaram por reforçar a ideia de que a fala era caótica e que apenas a escrita poderia ser tomada como "modelo" da linguagem "certa".

Bagno comenta ainda queHouaiss (1985, p. 133) faz referência a essa divisão estanque utilizando o termo "polarização maniqueísta", justamente pelo fato de tratar essas duas formas enunciativas com um juízo de valor dicotômico que traz a ideia de bom e mau, em que a escrita estaria associada à concepção positiva e a fala, à negativa. A consequência disso, segundo o autor, é a "alegação de que é preciso eliminar 'as interferências da fala na escrita'” (BAGNO, 2011, p. 345), visão marcada no senso comum e adotada pelos "defensores da língua pura". 9

Concepções como essa ainda reverberam nos discursos de alguns docentes, inclusive os em formação ${ }^{10}$, e talvez possam justificar porque o ensino da oralidade tem tido tão pouco espaço nas escolas, nas práticas pedagógicas do professor de português e, também, nas de outras disciplinas.

\subsection{A inter-relação entre o oral e o escrito}

A partir da segunda metade do século XX, consolidou-se nos estudos linguísticos a ideia de que não se pode entender o oral e o escrito como modalidades excludentes.

\footnotetext{
${ }^{9}$ A concepção de heterogeneidade linguística, que se opõe à essa noção de "interferência da fala na escrita", é defendida hoje por diversos pesquisadores. A esse respeito, ver Marcuschi (2010) e Côrrea (2010).

${ }^{10}$ Referimo-nos aqui às observações feitas durante aulas ministradas por nós, em um curso de licenciatura em Letras, cujo enfoque era a reflexão sobre a linguagem oral e escrita em diferentes contextos.
} 
Marcuschi (2001, 2010), por exemplo, distanciando-se dessa ideia, propõe que essas duas modalidades sejam observadas como um continuum, isto é, numa perspectiva que pressupõe uma inter-relação entre o oral e o escrito. Além disso, interessa para o autor compreender essas duas formas enunciaivas dentro de uma situação comunicativa concreta, inclusive observando os gêneros textuais/discursivos em que se dá essa comunicação. É, assim, uma visão mais dialógica e discursiva de uso dessas modalidades.

Para ele, as semelhanças entre essas duas modalidades são maiores que as diferenças, dessa forma, ele irá evidenciar que:

$\checkmark$ tanto a fala como a escrita, em todas as suas formas de
manifestação textual, são normatizadas (não se pode dizer
que a fala não segue normas por ter enunciados incompletos
ou por apresentar muitas hesitações, repetições e
marcadores não lexicados);
$\checkmark$ tanto a fala como a escrita não operam nem se constituem
numa única dimensão expressiva, mas são multissistêmicas
(por exemplo, a fala serve-se da gestualidade, mímica,
prosódia etc.; e a escrita serve-se da cor, tamanho, forma das
letras e dos símbolos, como também de elementos
logográficos, icônicos e pictóricos, entre outros, para fins
expressivos);

(MARCUSCHI, 2010, p. 46)

Levando em conta essa inter-relação, podemos entender as relações entre esses modos de produção a partir dos gêneros utilizados. Assim, se observássemos, por exemplo, uma entrevista, poderíamos perceber aspectos do modo de apresentação oral - ainda que marcados na escrita -, mas também admitiríamos traços do modo de produção escrito - mesmo que este ocorresseno âmbito de explicitação oral. Além disso, é possível observar textos escritos mais próximos da fala (como o bilhete) e textos falados que evidenciam aspectos da escrita formal (como a palestra).

Para evidenciar a gradação e interligação entre o oral e o escrito, Marcuschi propõe um esquema, tomando como ponto de observação o gênero discursivo e a situação comunicativa em que ocorre a produção do enunciado, como visto no esquema abaixo. 
Figura1 - Continuum fala-escrita, sob o enfoque dos gêneros

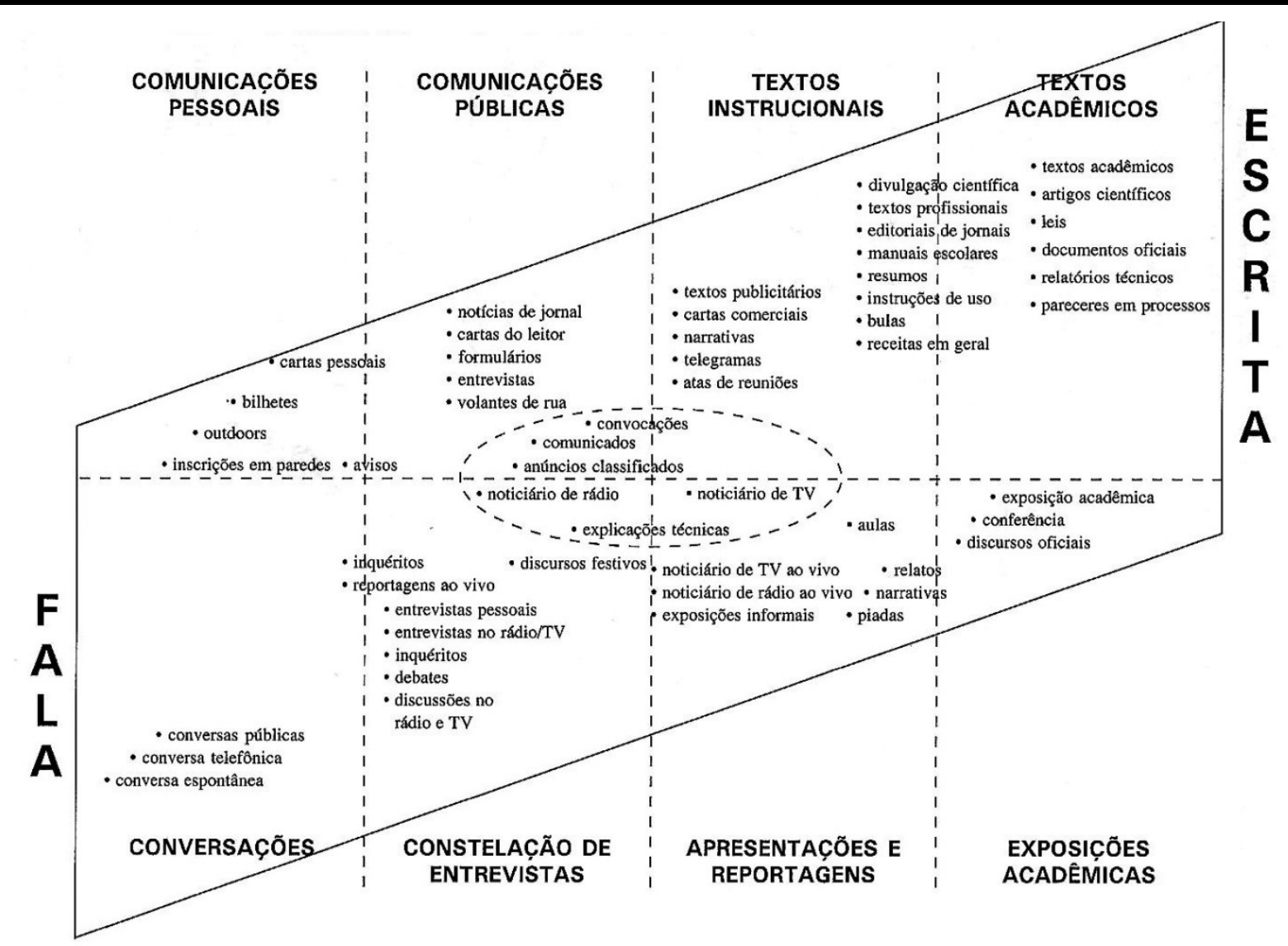

(MARCUSCHI, 2010, p. 41).

A proposta apresentada por Marcuschi representa um avanço no tocante em que fornece elementos para que os estudos da linguagem possam ter novos parâmetros para compreender o oral e o escrito em sua multiplicidade e dinamicidade e não mais apenas na simplificação de sua materialidade de realização concreta.

O cuidado que se deve ter, no entanto, ao falarmos em um "continuum" é não compreender essa expressão como dois polos que vão do simples ao complexo, o que seria cair novamente em uma bipolaridade. Além disso, não se pode admitir que um discurso seja observado unicamente em relação ao seu modo de produção oral ou escrito (o que se poderia imaginar se tomássemos esse continuum sob um enfoque unilateral).

Sentimos falta, nessa visão, de uma consideração que inclua a valoração do dito, só observável na singularidade do evento e, por esse motivo, não esquematizável. É sob esse aspecto que defendemos que para o ensino do oral não 
bastam apenas indicar o gênero em que o discurso será produzido ou indicar as relações gerais da situação de comunicação que envolve a produção, mas é fundamental que, ao observar uma prática concreta, o aluno seja estimulado a refletir sobre que valores estão em jogo na produção do enunciado.

Entendemos, então que, uma vez que a complexidade de qualquer texto não reside em sua materialidade, mas na própria relação desta com a situação comunicativa e os interlocutores envolvidos, é fundamental, em qualquer análise discursiva, observar todos esses aspectos. A teoria da "grande divisa", portanto, sede lugar a estudos que consideram as práticas comunicativas em contextos específicos, sejam eles produzidos no modo oral ou no escrito.

\subsection{Oralidade sob a perspectiva interacional face a face}

\subsubsection{Projeto Nurc}

$\mathrm{Na}$ década de 70, os avanços em relação aos estudos da língua falada tiveram como ponto de partida o desenvolvimento de uma pesquisa desenvolvida em diversas capitais brasileiras: o Projeto de Estudos da Norma Linguística Urbana Culta. O Projeto NURC, como ficou conhecido, tinha como principal objetivo descrever os falares de pessoas cultas no Brasil, evidenciando como era a norma utilizada na produção desses discursos orais.

Segundo Silva (1996), a semente desta ideia surgiu em 1964, por ocasião de um congresso realizado na Espanha em que se apresentou uma proposta para o estudo da norma culta no espanhol falado. A ideia inicial era que esse projeto também fosse ampliado para países de Língua Portuguesa, o que começou a consolidar-se no final da década de 60.

Em janeiro de 1968, por ocasião do IV Simpósio do PILEI [Programa Interamericano de Linguística e Ensino de Idioma] no México, o Prof. Nélson Rossi, da Universidade Federal da Bahia, apresentou 0 trabalho "O Projeto de Estudo da Fala Culta e sua Execução no Domínio da Língua Portuguesa". Nesse estudo, o Prof. Nelson Rossi ressaltou que, diferente dos países de língua espanhola, no Brasil, o "Proyeto" não poderia limitar-se à capital do país nem ao Rio de Janeiro. Ele sugeriu que o "Proyeto" deveria abranger as cinco principais capitais com mais de um milhão de habitantes: Recife, Salvador, Rio de Janeiro, São Paulo e Porto Alegre.

(SILVA, 1996, p. 84). 
Em 1969, foram definidos quais seriam os pesquisadores responsáveis pelos estudos em cada uma das cinco capitais brasileiras: (1) Recife, Prof. José Brasileiro Villanova; (2) Salvador, Prof. Nélson Rossi; (3) Rio de Janeiro, Prof. Celso Cunha; (4) São Paulo, Prof. Isaac Nicolau Salum - substituído pelo Prof. Dino Preti em 1981 - e Prof. Ataliba Teixeira de Castilho; (5) Porto Alegre, Prof. Albino de Bem Veiga. (SILVA, 1996).A partir dessa organização, o projeto Nurc consolidou-se como um trabalho em nível nacional sobre a língua falada.

Segundo Preti (2006), esse projeto permitiu observar vários níveis de formalidade de falantes cultos, relacionando-os com os fatores contextuais em que se dava o discurso.

Os registros do projeto Nurc-SP ${ }^{11}$ foram realizados de 1971 a 1977 em três situações distintas: (1) elocuções formais, gravações de aulas e conferências; (2) entrevistas; (3) diálogos entre dois informantes. (PRETI, 2006). Tal corpus representou um avanço nos estudos da língua falada na medida em que proporcionou o desenvolvimento de diversas pesquisas nesta área.

Como resultado desta coleta de dados, diversos artigos foram publicados, assinados, em sua maioria, por pesquisadores da Universidade de São Paulo que participaram/participamdo grupo NURC-SP. Tais artigos integram a coletânea do Projeto, publicados a partir da década de 1990 (com reedição nas décadas seguintes) até os dias atuais ${ }^{12}$. A tabela a seguir evidencia o trabalho de duas décadas realizado pelo grupo.

\footnotetext{
${ }^{11}$ Embora sejam relevantes todos os artigos publicados no projeto NURC em nível nacional, optamos, nesta pesquisa, por apresentar os estudos do polo de São Paulo.

${ }^{12}$ Observe-se, por exemplo, que o volume 12 foi publicado em 2014, período de desenvolvimento desta pesquisa, portanto.
} 
Tabela 1 - Projeto NURC-SP - obras publicadas ${ }^{13}$

\begin{tabular}{ccl}
\hline Volume & Ano & Título \\
\hline 1 & 1993 & Análise de textos orais \\
\hline 2 & 1997 & O discurso oral culto \\
\hline 3 & 1998 & Estudos de língua falada: variações e confrontos \\
\hline 4 & 2000 & Fala e escrita em questão \\
\hline 5 & 2002 & Interação na fala e na escrita \\
6 & 2003 & Léxico na língua oral e na escrita \\
\hline 7 & 2005 & Diálogos na fala e na escrita \\
\hline 8 & 2006 & Oralidade em diferentes discursos \\
\hline 10 & 2008 & Cortesia verbal \\
\hline 11 & 2009 & Oralidade em textos escritos \\
\hline 12 & 2011 & Variações na fala e na escrita \\
& 2014 & Comunicação na fala e na escrita \\
\hline
\end{tabular}

Fonte: Elaborado pela autora

Como é possível observar pelos títulos de cada volume, a coleção trata de diferentes temas, observando a língua falada sob diversos enfoques. Embora a organização seja do Prof. Dino Pretti, os artigos, no interior de cada obra, são assinados por diferentes pesquisadores.

Alguns aspectos desenvolvidos por esse grupo de estudos, no que se refere à questão da relação fala e escrita, são significativos para a compreensão de como o texto oral constitui-se. Sobre eles trataremos no tópico a seguir.

\subsubsection{Constituição do texto oral}

O que de fato caracterizaria a língua falada? Em busca de uma resposta, alguns artigos da coletânea percorrem esse estudo, evidenciando as relações entre fala e escrita.

Rodrigues (2003) aponta para o fato de que a mera transcrição do discurso oral para o plano do escrito não seria suficiente para considerá-lo como "língua escrita". De fato, esse tipo de compreensão fatalmente nos guiaria para uma concepção de língua escrita como mera reprodução da fala, ideia a muito superada.

\footnotetext{
${ }^{13}$ As referências completas de todos os volumes estão na bibliografia final deste trabalho.
} 
A autora alerta que no processo de transcrição da fala dados como expressão facial, gestos, olhares e movimentos do corpo se perdem, privando o pesquisador de uma compreensão mais global da situação comunicativa. Para suprir essa defasagem, são relevantes algumas pistas verbais sinalizadas no processo de transcrição, como "risos", ou indicação de "vozes" que se entrecruzam com o discurso analisado.

Urbano, ao tratar da questão do planejamento do texto oral, aponta que existe uma diversidade possível, a saber: (1) planejamento prévio e local, (2) planejamento temático ou de conteúdo, (3) planejamento verbal, (4) planejamento rítmico, (5) planejamento de formas e modos de utilização do discurso, (6) planejamento estilístico, (7) planejamento pragmático, dentre outros. Mas, para afastar qualquer ideia dicotômica, acrescenta que "esses níveis, considerados de modo geral sob a perspectiva do texto falado, podem, com exceção talvez dos níveis prosódico e psicológico, aplicar-se perfeitamente ao planejamento do texto escrito." (URBANO, 2006, p. 134)

Reforçando a relação entre o oral e o escrito, sob o enfoque de um continuum, Leite apresenta como uma crônica produzida pelo mesmo jornalista, mas divulgada em meios diferentes - rádio e jornal impresso - e, portanto, ligados a modos de produção oral e escrito, podem estar relacionados:

O texto escrito, pensado, preparado e articulado, foi oralizado na rádio, mas os dois [o publicado na rádio e o do jornal impresso] são tão intimamente ligados que é quase impossível separá-los, e, assim, dizer o que é próprio da oralidade e o que é da escrita. O que é da oralidade na escrita está estilizado. O que é escrito no oral nasceu estilizado. Ambos, por isso, são pertencentes ao gênero secundário $^{14}$. Esse é um caso típico em que a oralidade deve-se não somente à utilização da fala para sua veiculação como também a alguns recursos que intencionalmente o enunciador usou. Nesse caso, o enunciado é falado-escrito assim como o escrito é um escrito-falado.

(LEITE, 2006, p. 90-91)

\footnotetext{
${ }^{14}$ Ao usar esse termo, a autora retoma um conceito bakhtiniano, segundo o qual os gêneros poderiam ser divididos em primários e secundários. No primeiro caso, estariam ligados a "circunstâncias de uma comunicação verbal espontânea" - oral, na maioria das vezes - e seriam, por isso, mais simples. No segundo caso, apareceriam em "circunstâncias de uma comunicação cultural, mais complexa e relativamente mais evoluída, principalmente escrita". (BAKHTIN, 2011, p. 281). Essa concepção, no entanto, tem sofrido críticas por induzir a um pensamento que retoma a polarização entre os discursos orais e escritos, dicotomizados em relação a uma possível simplicidade ou complexidade. Trataremos no próximo capítulo sobre essa questão.
} 
A análise por ela empreendida evidencia como o planejamento foi necessário tanto na produção do discurso escrito como na sua reelaboração para a modalidade oral, não havendo, pois, uma divisão desse aspecto em cada um dos modos de representação da língua: fônico ou gráfico.

Sua tese confirma que, embora o conteúdo básico da mensagem tenha sido mantido, o meio mudou a mensagem. Baseia-se, para isso, na análise da expressividade, a qual foi construída tanto na relação com o que foi enunciado, quanto na relação do interlocutor com os enunciados dos outros (BAKHTIN, 2011). Nas palavras da autora:

A expressividade do enunciado oral é direcionadora, cria outro texto, porque dirige a imaginação do ouvinte. A expressividade do texto escrito deixa ao leitor a construção, em sua mente, das cadências, dos tons e da intensidade com que o texto vai sendo lido, e o sentido, construído.Assim, por exemplo, todo o diálogo que o enunciador travou consigo mesmo, e que foi lido de uma maneira e obrigou o ouvinte a pensar naqueles enunciados daquele modo, e não de outro, podem ter sido lidos de modos diferentes por milhares de leitores.

(LEITE, 2006, p. 103)

Essa ideia defendida por Leite (2006) já evidencia que não é possível um total distanciamento do escritor no momento de produção do texto escrito. Entendemos, então, que tal distanciamento pode ocorrer em função do gênero escolhido ou da finalidade da comunicação, mas que isso acontece tanto na língua falada quanto na escrita. Não é, pois, uma especificidade exclusiva de uma ou outra modalidade.

Outra característica importante sobre o discurso oral - e que não deixa de ter sua correspondente no texto escrito - é a possibilidade da (re)formulação linguística para adequar ou qualificar o discurso. Hilgert (2006), observando a construção linguística de diálogos constituídos na interação face a face, faz apontamentos que evidenciam a metadiscursividade - o dizer sobre o dizer - em que os próprios falantes assumem uma postura de observadores do seu dito, acrescentando comentários ou observações em seus textos. 
Para ele, essa marca no enunciado só confirma o caráter heterogêneo da linguagem, sua característica dialógica. Assim, retomandoBakhtin (2011), o autor afirma:

Para além das relações dialogais face a face, o dialogismo se revela no caráter responsivo dos discursos. Todo discurso, ao mesmo tempo em que responde a outros discursos, desencadeia novas formas de manifestação discursiva. Confluem, assim, por procedimentos mostrados ou não, diferentes vozes na constituição dos discursos, o que implica dizer que eles não são monológicos.

(HILGERT, 2006, p. 165).

Esse caráter da linguagem - 0 dizer sobre 0 dito - revela um posicionamento de quem enuncia, pois ao modalizar seu discurso ele manipula sua linguagem, negociando sentidos para instaurar um novo ponto de vista na constituição do enunciado produzido.

Outras duas características citadas pelo autor (HILGERT, 2006) apontam para o aspecto da metadiscursividade que podem ocorrer tanto no contexto oral quanto no escrito. São elas: a não-coincidência do discurso consigo mesmo e a nãocoincidência das palavras consigo mesmas. Enquanto as primeiras referem-se à menção, no texto, ao discurso de outrem ("como se diz", "tem um ditado aí", "como chamam..."), as segundas tratam da tentativa de explicar, de outra forma, uma palavra ou expressão de sentido mais aberto (como ocorre, por exemplo, ao citar "minha terra" e, em seguida, colocar "eu falo do Rio Grande do Sul do Brasil"). Em ambos os casos, o que fica evidente é o foco em uma autoria compartilhada, em que se evidencia ainda mais o discurso dito e o discurso citado, caracterizando-se ainda mais o aspecto heterogêneo da língua.

Apontamentos como os tratados neste tópico evidenciam que as discussões acerca da relação entre fala e escrita foram bastante significativas no interior dos grupos de estudos a que estavam ligados os pesquisadores do projeto Nurc, não só por ressaltar a importância de uma correlação entre as duas modalidades da língua, como também por discutir aspectos pontuais do discurso oral, especialmente os evidenciados em situação de conversação espontânea.

As gravações registradas no interior dessa pesquisa serviram igualmente de base para a elaboração de gramáticas voltadas à discussão do texto falado. Tais 
estudos transcorreram também - como as obras do projeto Nurc - na década de 90 e adentraram os anos 2000.Trataremos desses estudos no tópico a seguir.

\subsection{Oralidade sob a perspectiva gramatical}

\subsubsection{Projeto Gramática do Português culto falado no Brasil}

Em 1987, um novo projeto viria a fortalecer os estudos sobre oralidade: o Projeto de Gramática do Português Falado, apresentadono II Encontro da Associação Nacional de Pós-Graduação em Letras e Linguística - ANPOLL - pelo Prof. Ataliba Teixeira de Castilho e desenvolvido por pesquisadores de universidades públicas e privadas de todo o Brasil. Tal projeto tinha como objetivo "a preparação de uma gramática referencial da variante culta do português falado no Brasil" (SILVA, 1996, p. 89).

A proposição dessa obra apontava para um novo lugar para a língua falada, tratada não mais como o lugar do erro, como foi em outrora, mas tomando seu devido lugar dentro dos estudos linguísticos: uma modalidade com características próprias, apesar de não excludente. A coletânea advinda desse projeto figura na tabela a seguir:

\section{Tabela 2 - Gramática do Português Falado - obras publicadas ${ }^{15}$}

\begin{tabular}{ccll}
\hline Ano & Vol. & \multicolumn{1}{c}{ Subtítulo } & \multicolumn{1}{c}{ Organizador(es) } \\
\hline 1990 & I & A ordem & Ataliba Teixeira de Castilho \\
1992 & II & Níveis de análise linguística & Rodolfo llari \\
1993 & III & As abordagens & Ataliba Teixeira de Castilho \\
1996 & IV & Estudos descritivos & $\begin{array}{l}\text { Ataliba Teixeira de Castilho } \\
\text { Margarida Basílio }\end{array}$ \\
& & & Mary Kato \\
1996 & V & Convergências & IngedoreGrunfeld Villaça Koch \\
1996 & VI & Desenvolvimentos & Maria Helena de Moura Neves \\
1999 & VII & Novos estudos & Maria Bernardete Marques Abaurre \\
2003 & VIII & Novos estudos descritivos & Angela Cecília S. Rodrigues \\
& & & \\
& & & \\
& & & \\
& &
\end{tabular}

Fonte: Elaborado pela autora.

\footnotetext{
${ }^{15}$ As referências completas de todos os volumes estão na bibliografia final deste trabalho.
} 
Segundo Silva (1996), o corpus utilizado como análise para o desenvolvimento dessa gramática foi o material do NURC, o que coloca em evidência os desdobramentos do Projeto coordenado pelo Prof. Dr. Dino Preti.

Castilho (2010), ao apontar as motivações para a produção dessa gramática, afirma que no interior das discussões advindas dos estudos do Projeto Nurc observou uma lacuna no que se refere aos estudos propriamente gramaticais que envolviam a língua falada.

O Projeto NURC, como todos sabem, introduziu a pesquisa sobre a oralidade na Linguística brasileira, formulando perguntas muito instigantes sobre um objeto que parecia tão banal, a conversação, dotando ademais a comunidade de um extenso corpus, que esse projeto explorou em seus aspectos maiormente pragmáticos.

Mas a pesquisa gramatical tinha ficado de fora naquele projeto. Os instrumentos previstos pelo NURC para esse fim se mostraram insuficientes: Castilho (1990). Surgiu assim, a partir de outras perguntas, o Projeto de Gramática do Português Falado (PGPF), que atuou por vinte anos e produziu oito volumes de ensaios, muitas dissertações e teses.

(CASTILHO, 2010, p. 120)

A coletânea coordenada por Castilho surgiu, assim, com o objetivo de organizar uma gramática referencial dos falares ligados à variante de prestígio utilizada pelos falantes de Língua Portuguesa no Brasil. O intuito da obra era descrever e analisar o português falado em diversos níveis: fonológico, morfológico, sintático e textual. Pela natureza dinâmica que o estudo exigia, optou-se por não delimitar um único recorte teórico, assim, a análise pôde ser feita com a contribuição de diversas abordagens do conhecimento científico e teve como corpus uma seleção de entrevistas divulgadas pelo Projeto Nurc. (CASTILHO, 2014)

A publicação da Gramática do Português Falado - desenvolvida entre as décadas de 80 e 90 - favoreceu o surgimento de outras obras com objetivos similares: o estudo das características e especificidades da língua em sua modalidade oral.

Uma delas - uma continuação do estudo anterior - foi a Gramática do Português Culto Falado no Brasil, obra com coordenação geral do Prof. Dr. Ataliba Teixeira de Castilho e contribuição de pesquisadores de todo o país. 
Tabela 3 - Gramática do Português Culto Falado no Brasil - 1a fase ${ }^{16}$

\begin{tabular}{ccll}
\hline Ano & Vol. & \multicolumn{1}{c}{ Subtítulo } & \multicolumn{1}{c}{ Organizador(es) } \\
\hline 2006 & I & Construção do texto falado & $\begin{array}{l}\text { Clélia Cândida Abreu SpinardiJubran } \\
\text { IngedoreGrunfeld Villaça Koch }\end{array}$ \\
2009 & II & $\begin{array}{l}\text { Classes de palavras e processos de } \\
\text { construção }\end{array}$ & $\begin{array}{l}\text { Rodolfo llari } \\
\text { Maria Helena Moura Neves } \\
\text { Mary Kato }\end{array}$ \\
2008 & III & $\begin{array}{c}\text { A construção da sentença } \\
\text { Mílton do Nascimento }\end{array}$ \\
Inédito & IV & Construção morfológica da palavra & $\begin{array}{l}\text { Ângela C. Rodrigues } \\
\text { leda Maria Alves }\end{array}$ \\
Inédito & V & Construção fonológica da palavra & Maria Bernadete Marques Abaurre \\
& \multicolumn{2}{c}{ Coord. Geral: Ataliba Teixeira de Castilho - 1ª̂nedição - Editora da Unicamp } \\
\hline
\end{tabular}

Fonte: Elaborado pela autora.

SegundoJubran (2006a), a elaboração desta nova série orientou-se por uma perspectiva textual-interativa, a partir da qual a língua era entendida, em primeira instância, em seu caráter comunicativo. Assim, o aspecto verbal estudado era encarado dentro dessas condições de interação e não como sistema isolado. Como decorrência disso, o objeto de estudo passou a ser o texto, fruto da interação social.

A autora coloca ainda que o direcionamento teórico assumido na coletânea passa por três áreas: Pragmática, Linguística Textual e Análise da Conversação. Esclarece, no entanto, a que fase dessas ciências a obra se afilia.

A dimensão comunicativo-interacional, por exemplo, tem como base a Pragmática que observa o contexto da comunicação como uma marca dentro do texto e não como objeto isolado, que apenas margeia o enunciado. Afirma, assim, que "as condições comunicativas que sustentam a ação verbal inscrevem-se na superfície textual, de modo que se observam marcas do processamento formulativointeracional na materialidade linguística do texto." (JUBRAN, 2006, p. 29).

No que tange à Linguística Textual,a autora esclarece que a obra não se afilia a esta corrente em sua primeira fase, quando apenas se fazia uma aplicação da linguística frasal ao texto, mas às fases posteriores, em que o texto passa a existir apenas em situação real de comunicação, na interação social.

Para realizar uma descrição textual-interativa da língua falada, a coletânea usa os pressupostos da Análise da Conversação, não focando em aspectos

\footnotetext{
${ }^{16}$ As referências dos volumes publicados estão na bibliografia final deste trabalho.
} 
etnometodológicos - cujas bases não dariam condição para uma leitura linguísticotextual do corpus -, mas em "situações diversificadas de intercurso verbal", sem restringir o estudo a "situações altamente informais de interlocução". (op. cit., p. 30). O texto, assim, é analisado sempre considerando a situação em que foi produzido.

O que é tomado como "gramatical" no plano do texto, segundo a concepção dos pesquisadores que engendraram a obra, refere-se às regularidades na construção do texto falado dentro de um contexto dado.

O caráter sistemático de determinados procedimentos de formulação textual é dado pela recorrência desses procedimentos em contextos definidos, pelas marcas formais que os caracterizam e pelo preenchimento de funções que Ihes são específicas. Esta é a concepção do grupo sobre o que vem a ser gramatical no plano do texto.

(JUBRAN, 2006, p. 31)

Segundo Castilho (inédito), a organização da Gramática do Português Culto Falado no Brasil foi repensada, pois os pesquisadores envolvidos entenderam que cinco volumes não seriam suficientes para abarcar todos os aspectos que mereciam atenção. A obra foi, então, revista e repensada em sete volumes, todas a serem publicadas pela Editora Contexto e não mais pela Editora da Unicamp.

Tabela 4 - Gramática do Português Culto Falado no Brasil - $2^{\mathrm{a}}$ fase ${ }^{17}$

\begin{tabular}{ccll}
\hline Ano & Vol. & \multicolumn{1}{c}{ Subtítulo } & \multicolumn{1}{c}{ Organizador(es) } \\
\hline 2015 & I & Construção do texto falado & Clélia Cândida A. SpinardiJubran \\
2015 & II & A construção da sentença & Mary Kato \\
& & & Mílton do Nascimento \\
2014 & III & Palavras de classe aberta & Rodolfo llari \\
2015 & IV & Palavras de classe fechada & Rodolfo llari \\
2016 & V & A construção das orações complexas & Maria Helena Moura Neves \\
2015 & VI & Construção morfológica da palavra & Ângela C. Rodrigues \\
& leda Maria Alves \\
2013 & VII & Construção fonológica da palavra & Maria Bernadete Marques Abaurre \\
& & & \\
& & Coord. Geral: Ataliba Teixeira de Castilho $-2^{2}$ edição - Editora Contexto \\
\hline
\end{tabular}

Fonte: Elaborado pela autora.

De forma geral, nessa nova edição, o antigo vol. II, que tratava de "Classes de palavras e processos de construção", foi desmembrado e ampliado, gerando o que, na $2^{\text {a }}$ edição tornaram-se os volumes 3,4 e 5, respectivamente: "Palavras de

\footnotetext{
${ }^{17}$ As referências completas das obras estão na bibliografia final deste trabalho.
} 
classe aberta", "Palavras de classe fechada" e "Construções hipotáticas". Os demais capítulos mantêm os mesmos títulos da edição publicada pela Editora da Unicamp.

Evidenciamos, a seguir, uma comparação entre essas duas fases na elaboração da coleção Gramática do Português Culto Falado no Brasil para deixar clara a relação entre as obras publicadas pela editora da Unicamp ( $1^{\text {a }}$ fase) e editora Contexto (2 $2^{\mathrm{a}}$ fase).

\section{Tabela 5 - Comparação das fases de publicação da coleção "Gramática do Português Culto Falado no Brasil"}

\begin{tabular}{|c|c|c|c|c|c|}
\hline \multicolumn{3}{|r|}{$\begin{array}{c}1^{\text {a }} \text { fase } \\
\text { (Editora da Unicamp) }\end{array}$} & \multicolumn{3}{|c|}{$\begin{array}{c}2^{\mathrm{a}} \text { fase } \\
\text { (Editora Contexto) }\end{array}$} \\
\hline Ano & Vol. & Título / Organizador & Vol. & Título / Organizador & Ano \\
\hline 2006 & I & $\begin{array}{l}\text { Construção do texto falado } \\
\text { * Clélia C. A. SpinardiJubran } \\
\text { * IngedoreGrunfeld Villaça } \\
\text { Koch }\end{array}$ & I & $\begin{array}{l}\text { Construção do texto falado } \\
\text { * Clélia C. A SpinardiJubran }\end{array}$ & 2015 \\
\hline \multirow[t]{3}{*}{2009} & \multirow[t]{3}{*}{ II } & \multirow{3}{*}{$\begin{array}{l}\text { Classes de palavras e } \\
\text { processos de construção } \\
{ }^{\star} \text { Rodolfo llari } \\
{ }^{*} \text { Maria Helena de M.Neves }\end{array}$} & III & $\begin{array}{l}\text { Palavras de classe aberta } \\
{ }^{*} \text { Rodolfo llari }\end{array}$ & 2014 \\
\hline & & & IV & $\begin{array}{l}\text { Palavras de classe fechada } \\
{ }^{*} \text { Rodolfo llari }\end{array}$ & 2015 \\
\hline & & & V & $\begin{array}{l}\text { A construção das orações complexas } \\
{ }^{*} \text { Maria Helena de M. Neves }\end{array}$ & 2016 \\
\hline 2008 & III & $\begin{array}{l}\text { A construção da sentença } \\
\text { * Mary Kato } \\
\text { * Mílton do Nascimento }\end{array}$ & II & $\begin{array}{l}\text { A construção da sentença } \\
{ }^{*} \text { Mary Kato } \\
{ }^{*} \text { Mílton do Nascimento }\end{array}$ & 2015 \\
\hline Inédito & IV & $\begin{array}{l}\text { Construção morfológica da } \\
\text { palavra } \\
\text { * Ângela C. Rodrigues } \\
\text { * leda Maria Alves }\end{array}$ & $\mathrm{VI}$ & $\begin{array}{l}\text { Construção morfológica da palavra } \\
\text { * Ângela C. Rodrigues } \\
\text { * leda Maria Alves }\end{array}$ & 2015 \\
\hline Inédito & V & $\begin{array}{l}\text { Construção fonológica da } \\
\text { palavra } \\
{ }^{\star} \text { Maria Bernadete M. Abaurre }\end{array}$ & VII & $\begin{array}{l}\text { Construção fonológica da palavra } \\
\text { * Maria Bernadete M. Abaurre }\end{array}$ & 2013 \\
\hline
\end{tabular}

Fonte: Elaborado pela autora.

Em relação aos pesquisadores responsáveis pela organização da coleção, observamos que eles se mantiveram em quase todos os volumes, exceção apenas ao volume I, que em 2015 não teve a participação de Ingedore G. V. Koch. Outra diferença em relação a isso é que o vol. II de 2009 (1 ${ }^{a}$ fase) era organizado por llarie 
Moura Neves, mas como esse volume foi desmembrado em três outros para a edição da editora Contexto ( $2^{\underline{a}}$ fase), cada volume ficou com um deles como responsável. Assim, os volumes III e IV foram organizados por Rodolfo llari e o volume V por Maria Helena de Moura Neves.

Discutiremos, no tópico a seguir, alguns aspectos da regularidade do texto falado apontados na obra.

\subsubsection{Natureza da modalidade oral}

Os modos de produção oral e escritasão sistemas complementares de compreensão do mundo. Na perspectiva da organização textual-discursiva, no entanto, é significativo conhecer as especificidades do modo de enunciação oral uma vez que, como Koch (2006), entendemos fala e escrita como duas modalidades, com características próprias, afastando a concepção de escrita como mera transcrição da fala.

Todo texto é resultado de uma coprodução entre interlocutores: o que distingue o texto escrito do falado é a forma como tal coprodução se realiza. No texto escrito, a coprodução se resume à consideração do outro para o qual se escreve, não havendo participação direta e ativa deste na elaboração linguística do texto, em função do distanciamento entre escritor e leitor. Consequentemente, inexistem marcas explícitas de atividade verbal conjunta. A dialogicidade aqui se estabelece por meio de uma relação 'ideal', em que o escritor desempenha o papel que lhe cabe, enquanto produtor do texto, assumindo, também, a perspectiva do leitor. No texto falado, por estarem os interlocutores copresentes, ocorre uma interlocução ativa que implica um processo de coautoria, refletido, na materialidade linguística, por marcas da produção verbal conjunta.

(KOCH, 2006, p. 40).

Na visão da autora, não há como negar que existe a participação de dois interlocutores - o produtor e o leitor/ouvinte - na produção de um texto, seja oral ou escrito, mas ressalta que a questão da presença/ausência destes últimos no momento de produção real do enunciado é um fator importante para compreensão das marcas que apontam para a produção oral ou escrita. Em outras palavras, podem-se entender no mínimo duas especificidades entre esses discursos: o próprio fato de um ser falado e outro escrito, e o contexto de cada uma dessas produções. 
Essa visão permite o entendimento de aspectos da escrita, por exemplo, quando há uma relativa proximidade com o leitor - como no caso da escrita de um bilhete quando o interlocutor encontra-se muito próximo. No modo de produção oral isso também fica claro e a autora também sinaliza para isso ao afirmar que existem "diferenças de grau de manifestação da coprodução verbal conjunta." (KOCH, 2006, p. 40).

Ainda entendendo a problemática das concepções estagnantes de uma visão dicotômica entre essas modalidades - como já apontado nesse capítulo Koch procura apontar o que poderia ser considerado como características próprias da fala. Elenca, para isso, cinco aspectos.

O primeiro estaria ligado ao fato de a produção oral ser "relativamente não planejável de antemão" (KOCH, 2006, p. 45). Para nós, é significativo o uso do termo "relativamente" nesta definição, uma vez que permite a possibilidade de alguma forma de planejamento, distanciando-se da concepção apontada na época da grande divisa: escrita planejada e fala não planejada. Entender a fala como "relativamente não planejada", implica em dizer que mesmo para a fala espontânea pode haver alguma forma de planejamento: do assunto, do uso vocabular adequado à situação, de formas linguísticas mais ou menos formais, e mesmo dos limites sobre o quanto se deve/precisa dizer em determinado momento.

O segundo aspecto apontado pela autora refere-se ao fato de o texto falado ser produzido em se fazendo, ou seja, a produção ocorre simultaneamente ao planejamento do texto. E, como resultado, podem ser observadas algumas marcas textuais que evidenciam o próprio processo de produção.

O terceiro ponto tem, de certa forma, uma relação com esse segundo: como o planejamento é constante, no decorrer de toda a produção oral, é possível que ocorram descontinuidades no fluxo discursivo. A sintaxe é, pois, menos linear e pode ser até mais complexa que a produção escrita, ao contrário do que se acreditava na visão dicotômica. Importante ressaltar que a ideia antes defendida de a fala ser mais simples possibilitava um entendimento de essas descontinuidades serem um erro, um problema, o que levava a crer que a fala era pouco organizada. Nessa nova visão, compreendendo os fatores interacionais de produção do texto, as pausas 
ehesitações são vistas como naturais e possuem, muitas vezes, justificativas implicadas na própria situação discursiva.

O quarto tópico apontado pela autora $(\mathrm{KOCH}, 2006)$ diz respeito ao fato de o texto falado apresentar uma sintaxe característica, ainda que continue fazendo uso da sintaxe geral da língua. Assim, não se trata de uma nova língua, mas de uma modalidade que traz aspectos pontuais que precisam ser observados.

Por fim, para apresentar o quinto aspecto característico da fala, a autora retoma a metáfora de Halliday $(1985$, apud $\mathrm{KOCH}, 2006)$, relacionando a escrita a um quadro - portanto estático - e a fala a um filme, por sua dinamicidade. Mais uma vez o foco está relacionado ao momento da produção do enunciado: é o resultado de um processo, quando escrito, e é o próprio processo, quando falado.

Considerando esses aspectos, a autora conclui que a própria situação de interação face a face, em uma produção imediata, vai levar à construção de um discurso que muitas vezes sofre a influência de "pressões de ordem pragmática", as quais "em muitos casos, obrigam o locutor a sacrificar a sintaxe em prol das necessidades da interação" (KOCH, 2006, p. 46). Como resultado desse aspecto, o texto falado pode apresentar não apenas "falsos começos, truncamentos, correções, hesitações", como ainda "inserções, repetições e paráfrases, que têm, frequentemente, funções cognitivo-interacionais de grande relevância." $(\mathrm{KOCH}$, 2006, p. 46).

Para Marcuschi, tanto a hesitação, quanto a interrupção são fenômenos específicos da oralidade, visto que "se manifestam em todos os gêneros de textos falados e não são constatados em textos escritos prototípicos" (MARCUSCHI, 2006, p. 47). Para o autor, a hesitação pode ser entendida como uma estratégia para "ganhar mais tempo", isto é, um recurso utilizado com vistas a repensar a própria produção do texto. A interrupção, por sua vez, teria objetivos diversos, dentre os quais cita a introdução de reformulação que fosse significativa para a progressão textual, e o acréscimo de informações - linguísticas ou contextuais - que colaborem para a compreensão do discurso produzido.

Linguisticamente, a hesitação poderia ser observada por: 
a) fenômenos prosódicos: pausas, geralmente prolongadas, e alongamentos vocálicos;

b) expressões hesitativas: éh, ah, ahn, $\mathrm{mm}$;

c) itens funcionais: artigos, preposições, conjunções, pronomes, verbos de ligação;

d) itens lexicais: substantivos, advérbios, adjetivos, verbos;

e) marcadores discursivos acumulados: sei lá; quer dizer sabe; então né ah etc.;

f) fragmentos lexicais: palavras iniciadas e não concluídas.

(MARCUSCHI, 2006, p. 50)

Com relação a sua funcionalidade, o autor aponta que apesar de a hesitação não ter um papel sintático pontual - visto que sua exclusão da sentença não implicaria em perdas gramaticais - seu uso está mais ligado a interferências de ordem discursivas, servindo, pois, de índice da formulação e evidenciando o maior ou menor domínio do falante em relação à tomada de turno no processo de comunicação. Dessa maneira, os que têm pouco domínio, acabam não fazendo uso da palavra, pois têm dificuldade para manter o turno. (MARCUSCHI, 2006).

No que tange ao processo de interrupção, Souza e Silva e Crescitelli (2006) evidenciam que esses inacabamentos são fruto de dois processos: (1) a autointerrupção, ocasião em que o falante decide fazer uma pausa no que está dizendo; (2) heterointerrupção, caso em que as paradas acontecem pela troca de turno forçada, ou seja, quando o interlocutor faz um assalto ao turno do outro que tem a palavra.

Para as autoras, a interrupção só pode ser considerada como tal quando temos, de um lado, um corte do que está sendo dito e, de outro, a sua retomada. Esses dois elementos caracterizariam os critérios fundamentais para evidenciar 0 caráter constante e sistemático da interrupção na língua falada. Em outras palavras, podemos dizer que houve interrupção em dois casos: quando há um corte e uma retomada, e quando há um corte sem a retomada. Este segundo caso seria menos comum que o primeiro.

As autoras ainda justificam o fato de a interrupção ser uma estratégia de produção do texto falado apontando que tal fenômeno não ocorre apenas com 
determinados indivíduos ou situações, mas é o resultado da relação temporal simultânea entre o planejamento e a produção textual concreta da fala.

Por fim, acrescentam:

Como fenômeno sinalizador, a interrupção aponta, ainda, para o caráter reflexivo da linguagem, isto é, para a possibilidade que esta tem de poder olhar para si mesma, de se voltar sobre aquilo que acabou de ser dito ou antecipar o que ainda vai ser proferido.

(SOUZA e SILVA; CRESCITELLI, 2006, p. 86)

Compreendemos, assim, que a interrupção, como fenômeno próprio da comunicação oral, desempenha um papel interacional significativo que tem marcas linguísticas e regularidades suficientes para serem observados com mais atenção no processo de reflexão sobre a linguagem em práticas educacionais concretas, como as que são pensadas para esse fim, no livro didático de português.

\subsection{Reconhecimento oficial para o ensino da oralidade}

Em 1997 e 1998, um documento oficial veio favorecer as reflexões acerca do estudo da oralidade nos meios escolares. Esse material - os Parâmetros Curriculares Nacionais ${ }^{18}$ de Língua Portuguesa, voltados para o primeiro (BRASIL, 1997) e segundo ciclos (BRASIL, 1998) do ensino fundamental- estabeleceu a oralidade como objeto de ensino, ao lado das práticas consolidadas de estudo da leitura, produção de texto e conhecimentos linguísticos.

Marcuschi aponta a importância dos PCN no que se refere a uma maior reflexão acerca das práticas orais nas escolas. Em trabalho sobre o papel da oralidade em Livro Didático de Português, o autor declara:

Os anos 90 marcaram uma guinada extraordinária neste sentido [0 progressivo aumento de sugestões de estudos sobre a fala] e certamente nos próximos anos teremos cada vez mais observações sobre a questão. Isto permite esperar que os autores de obras didáticas já não se mostrem mais insensíveis ao que sugerem os teóricos da linguística. Creio que os PCN, malgrado não ter uma concepção de oralidade mais nítida, servirão para dar aos estudos da oralidade um lugar mais adequado e explícito.

(MARCUSCHI, 2003, p. 26)

${ }^{18}$ Doravante, PCN. 
Para o autor (MARCUSCHI, 2003), ainda que os PCN tenham sofrido algumas críticas por apresentar certa confusão epistemológica, colocando autores de perspectivas diferentes lado a lado, para uma mudança em relação às práticas escolarizadas ele teve papel significativo.

A linguagem, naquele documento, não é vista como uma estrutura autônoma, mas como uma forma de ação interpessoal, isto é, está sempre voltada para uma situação social específica, com uma finalidade marcada, dentro de um tempo socio-histórico particular e com interlocutores que integram uma comunidade real. Observa-se, assim, uma ruptura com uma visão tradicional de ensino de língua, em que memorizar conceitos e reconhecer estruturas era o foco. Passa-se, então, a valorizar o seu estudo como forma de interação e, por isso mesmo, são as situações de uso da língua, nas suas duas modalidades - oral e escrita - que passam a ser o centro do ensino.

Apesar da centralidade que a escrita sempre assumiu nas aulas de português, nos PCN a oralidade tem o seu espaço, visto ser uma prática de uso da língua igualmente relevante.

No que tange à oralidade, os PCN (BRASIL, 1998) reafirmam que entender que a fala não precisa ser tomada como objeto de ensino, apenas por que dela se faz uso nas interações familiares, é um problema, uma vez que é papel da escola ampliar o repertório do aluno em relação ao uso da língua nas diversas situações sociais e isso implica também o uso em situações mais formais de interação.

Tomando o texto como base para o ensino, tanto nas modalidades escrita e oral, o documento invoca o conceito de gêneros do discurso (advindos dos estudos bakhtinianos) como norteador desse trabalho: “(...) a unidade básica do ensino só pode ser o texto. (...) a noção de gênero, constitutiva do texto, precisa ser tomada como objeto de ensino." (BRASIL, 1998, p. 23).

Os PCN, então, propõem uma atividade didática envolvendo escuta e produção de textos orais que levem em conta as diversidades de gêneros discursivos existentes.

Este trabalho, no entanto, não deve estar limitado apenas ao acesso a "formas" de comunicação, pois é fundamental levar o aluno a compreender as situações reais e concretas de seu uso, contribuindo para que ele possa dominar um 
determinado gênero de maneira a ter uma efetiva participação social. Assim, não basta explicar, por exemplo, a estrutura de um debate, é necessário que o educando perceba seu papel social, os contextos em que este gênero é requerido e as implicações do processo de produção na organização do discurso e na significação do enunciado. Além disso, é importante levar o aluno a perceber que seu discurso marca sempre um posicionamento ${ }^{19}$.

Neste sentido, o documento orienta um trabalho que ocorra no nível discursivo, semântico e gramatical, valorizando cada um de maneira equilibrada. $E$, no caso do texto oral, acrescenta-se a observação de o aluno estar atento também à seleção dos recursos prosódicos e gestuais.

O trabalho com oralidade, segundo os PCN, poderia ser desenvolvido a partir de escuta e produção de textos de gêneros de diferentes esferas. Para a escuta são sugeridos gêneros como cordel, causos, texto dramático, canção (esfera literária); comentário radiofônico, entrevista, debate, depoimento (esfera jornalística); exposição, seminário, debate, palestra (esfera de divulgação científica); propaganda (esfera publicitária). A sugestão de gêneros para a produção de textos orais não diferem muito destes, não sendo citados apenas o cordel e causos (esfera literária), comentário radiofônico (esfera jornalística), palestra (esfera de divulgação científica) e a propaganda (esfera publicitária). Acrescenta-se ainda, para a produção oral, a sugestão do gênero notícia. (BRASIL, 1998).

Para orientar a prática efetiva desse ensino, os PCN apresentam um caminho para o professor, que deve "organizar situações que possibilitem o desenvolvimento de procedimentos de preparação prévia e monitoramento simultâneo da fala”. (BRASIL, 1998, p.74). Os primeiros - preparação prévia estariam ligados à elaboração de esquemas, cartazes, roteiros que deem suporte ao texto oral; os segundos - monitoramento simultâneo - podem ser relacionados à participação efetiva do aluno em situações reais de interação em que o aluno possa observar as especificidades do gênero oral selecionado, e também estão ligados à análise dessas produções orais, não apenas através de gravações, masa partir de observações dos participantes. O objetivo dessas propostas é levar o professor e o aluno a "avaliar as facilidades e dificuldades encontradas no processo enunciativo, a

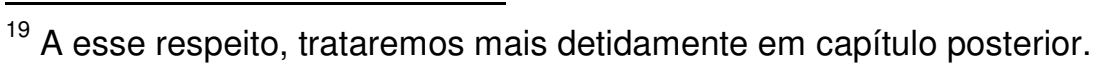


reação da audiência em função dos efeitos pretendidos, entre outros, de modo a instrumentalizar o aluno para melhorar seu desempenho". (BRASIL, 1998, p. 75).

A proposta de um ensino de língua que tome como ponto de partida o texto e os gêneros que circulam nas diversas esferas sociais, incluindo os que focam a oralidade, também está presente nos documentos oficiais posteriores à publicação dos PCN, como os Parâmetros Curriculares Nacionais para 0 Ensino Médio ${ }^{20}$ (BRASIL, 2000), os Parâmetros Curriculares Nacionais Mais ${ }^{21}$ (BRASIL, 2002) e as Orientações Curriculares para o Ensino Médio ${ }^{22}$ (BRASIL, 2006), evidenciando um encaminhamento já consolidado, ao menos no plano dos documentos oficiais, de um trabalho em que o oral tenha seu efetivo espaço na escola. Sobre esses documentos, trataremos no capítulo 3.

\subsection{Oralidade como objeto de ensino}

Para Fávero, Andrade e Aquino (2014), a publicação dos PCN de Língua Portuguesa (BRASIL, 1997/1998) oportunizou a abertura do trabalho com oralidade na escola, no entanto,a carência de estudos voltados a pensar na aplicação desse ensino também ficou evidente naquela época.

Marcuschi (2003) afirma que, de maneira geral, as pessoas acreditam que, por ser a língua oral utilizada com maior frequência que a escrita no dia-a-dia, não seria necessário estudá-la.

Tal equívoco, também apontado por outros pesquisadores (cf. CASTILHO, 1998; ANTUNES, 2003, FÁVERO, ANDRADE \& AQUINO, 2012), ainda está presente no discurso de alguns professores e também de estudantes dos cursos de licenciatura que se preparam para lecionar Língua Portuguesa, o que, provavelmente, é um reflexo do pouco espaço que se tem dado à oralidade nos cursos de formação docente, conforme demonstrou Innocêncio (2009), ao conversar com um professor recém-formado (citação 1), uma estudante do curso de Letras (citação 2) e uma professora do curso de licenciatura em Letras (citação 3):

\footnotetext{
20 Doravante, PCNEM.

${ }^{21}$ Doravante, $\mathrm{PCN}+$.

22 Doravante, OCEM.
} 
Olha, acho que toda essa discussão de gêneros, de oralidade, ainda fica um pouco a desejar na formação. Na verdade, me lembro de ter visto estas questões muito pouco. Tive uma professora, na Letras, que estuda argumentação, argumentação em sessões do PROCON, essas coisas, que tratou um pouco sobre a oralidade. Gêneros, acho que fomos estudar mesmo foi nas disciplinas pedagógicas da Faculdade de Educação. Acho que o curso de Letras, hoje, está muito focado em formar o pesquisador. Enquanto a gente está estudando, a maioria nem pensa que pode dar aula. Pensa que vai fazer pesquisa, mestrado, doutorado, essas coisas...(18-08-2009)

(Professor recém-formado pela Universidade Federal de Juiz de Fora. In: INNOCÊNCIO, 2009, p. 5)

$\mathrm{Na}$ faculdade em que estudo (uma instituição particular), fizemos uma disciplina chamada "Práticas orais e escritas". Todos nós estranhamos porque, no final do curso, não tínhamos tido uma única aula que tivesse tratado de práticas orais. Fomos comentar isso com a coordenadora. Ela nos disse que, talvez, seja o caso de se pensar uma disciplina apenas para as práticas orais (30-06-2010.)

(Aluna do curso de Letras da Universidade Federal de Juiz de Fora. In: INNOCÊNCIO, 2009, p. 5)

Segundo ela [professora que ministra aulas no curso de Letras de uma instituição particular de Juiz de Fora], também no curso em que atua, tal questão não tem o tratamento que deveria. Na formação, para ela, existe o mesmo grafocentrismo que é característico da escola. Não se preparam os futuros e futuras profissionais para estarem em situações práticas em que a dimensão da oralidade possa se expandir, tomando-a como objeto de aprendizagem.

(Professora do curso superior em Letras da cidade de Juiz de Fora. In: INNOCÊNCIO, 2009, p. 5 e 6)

O resultado dessa crença de que não seria necessário estudar a fala é uma visão que privilegia muito mais o ensino da escrita, em detrimento daquela, omitindo uma prática de exploração dos aspectos relativos ao oral.

Considerando a realidade dialógica da linguagem - concepção da qual partilhamos -, não é de se estranhar que os estudos sobre oralidade gerassem repercussões ligadas a seu ensino. Diversos pesquisadores, na tentativa de sanar uma lacuna entre a demanda presente nos PCN e a real concretização de um trabalho com oralidadena prática docente, publicaram trabalhos com propostas para esse ensino. 
Acreditamos, pois, ser relevante apresentar um pouco do universo de pesquisas que buscam sugerir/analisar ações ligadas às práticas de sala de aula, especificamente no que se refere ao nosso objeto de estudo.

Nesse esforço, retomamos, por um lado, as propostas ligadas à metodologia do trabalho com gêneros orais e, por outro, a forma como esse conteúdo é tratado no interior do livro didático de português, seja como meio para a realização de uma atividade, seja como objeto de ensino.

Nosso percurso, então, será apontar o que tem sido observado por pesquisadores sobre a apropriação dos estudos sobre oralidade para fins de uso prático em sala de aula, seja na prática docente, seja no encaminhamento apresentado no livro didático de português.

\subsubsection{Recepção nas práticas de sala de aula}

A publicação dos PCN (BRASIL, 1997, 1998, 2000) foi positiva no sentido de explicitar a oralidade como um dos eixos de ensino a que a escola deve se dedicar. Como isso deveria ser feito, no entanto, ainda não estava claro. Alguns estudiosos, então, dedicaram-se a pesquisas no intuito de apresentar algumas propostas para esse ensino nas escolas.

Castilho (2000), por exemplo, defende a ideia de que a língua falada seja tomada como ponto de partida para o ensino de gramática, não apenas por respeito a um aluno que, na maioria das vezes, não provém de um meio letrado e precisa ver na escola o seu modo de falar valorizado, mas também porque uma análise gramatical advinda da fala retiraria o aluno do lugar de mero "classificador" da língua para uma pessoa que consegue compreender os processos que levaram a uma determinada classificação.

Insisto que a gramática não é o lugar das certezas absolutas, e em classe não devemos transferir nossa capacidade de reflexão para o autor de uma gramática, por melhor que ele seja. É de todo inútil passar para os alunos o "pacote gramatical", o famoso "ponto" de gramática, cujo efeito prático será, infelizmente, afastar os educandos da reflexão. A aula de gramática deve implicar numa atuação participante de professor e alunos, movidos pelo desejo da descoberta científica. A ordenação dos achados é uma fase final no procedimento pedagógico." 
autor acrescenta ainda que este trabalho pode ser feito em contraponto com a língua escrita, reforçando a importância do estudo dessas duas modalidades. Para tanto, sugere combinar algumas formas textuais que podem ser observadas em gêneros diversos, a saber: (a) conversação simétrica / diálogos em peças de teatro; (b) conversação assimétrica / cartas, crônicas e noticiário de jornais e revistas; (c) aulas e conferências / narrativas e descrições contidas em romances e contos. (CASTILHO, 2000).

A ideia por ele apresentada visa levar o aluno analisar profundamente a língua e, a partir de sua materialidade, compreender o funcionamento efetivo da linguagem. Sua proposta metodológica de trabalho com a língua falada, por este motivo, deve iniciar em uma Análise da Conversação, passar por uma Linguística do texto, para depois chegar ao estudo da gramática, agora contextualizada e significativa para o aluno.

Ramos (1997), ao discutir o espaço da oralidade na sala de aula, assume o texto falado como ponto de partida para as produções escritas. Seu estudo mostra, por exemplo, que a apropriação da modalidade culta ${ }^{23}$ da língua poder-se-ia ocorrer a partir de uma situação cotidiana, a que o aluno e professor têm acesso, em que circula o oral culto, como no caso em que eles assistem a telejornais. Tomando a gravação de uma notícia como ponto de partida, a autora expõe os caminhos que o professor pode seguir:

(a) seleção do texto a ser gravado; (b) transcrição do texto pelo professor; (c) audição do texto original; (d) análise crítica do texto; (e) leitura da transcrição, ouvindo a fita; (f) leitura da transcrição, seguindo ou não o padrão de entoação e pronúncia da fita; $(\mathrm{g})$ redação do texto da notícia ou relatório da atividade realizada na sala naquela aula.

(RAMOS, 1997, p. 21)

A proposta da autora é iniciar pela escuta da gravação, o que facilita o processo de leitura silenciosa, pois o aluno pode ter uma base tanto de entoação,

\footnotetext{
${ }^{23}$ Bagno (2007) defende o uso do termo "variedade de prestígio" no lugar de "norma culta". Para ele, o termo "culto" é problemático, pois traz em si o seu oposto (inculto), ressaltando a ideia de que não haveria cultura na fala de grupos que não fizessem uso do modelo de língua socialmente valorizado. Concordamos com o posicionamento do autor, mas optamos por manter o termo "modalidade culta" nesse parágrafo apenas por referência ao que foi originalmente usado por Ramos (1997) no texto sobre o qual estamos tratando.
} 
quanto de compreensão de unidades de sentido. Em seguida, Ramos propõe a discussão da notícia para, só então, refazer a leitura oral num padrão diferente do original, com foco na explicitação de aspectos como qualidade de voz, entoação, expressão do rosto. A sugestão dada por ela é que este trabalho seja repetido em outras aulas, nas quais duas versões de uma mesma notícia oral possam ser apresentadas para comparação.

O objetivo de Ramos (1997) é trabalhar com a linguagem oral como meio para a reflexão de uso da língua - neste caso, com foco na discussão da variedade de prestígio. Sua intenção está ligada a uma proposta de estudo da língua que parta de algo que o aluno tem familiaridade, mas não da produção de textos orais autorais pelo discente.

Dessa forma, entendemos que, para o que se destina, a atividade cumpre o seu papel, mas numa prática didática concreta poderia ser ampliada, oportunizando não apenas a oralização do texto transcrito, mas a produção e posterior análise de um jornal falado criado, produzido e gravado pelos próprios alunos, em que, igualmente, poder-se-ia discutir a utilização das diversas variedades de uso da língua, além de oportunizar uma reflexão sobre esses usos de acordo com os interlocutores.

Também buscando uma prática que relacione a oralidade com a escrita, Fávero, Andrade e Aquino (2014) propõem um trabalho com manchetes de revistas e jornais nacionais e com as notícias a que fazem referência. O foco é mostrar não apenas as especificidades do texto, sua estrutura e efeitos de sentido obtidos pela escolha linguística realizada, mas também apontar de que forma a oralidade está presente na escrita, como quando parece haver um diálogo com o interlocutor. Além disso, sugerem a criação de um telejornal, estimulando a percepção do aluno em relação às adaptações de uma notícia do meio impresso para a apresentação oral, em rádio ou televisão.

A proposta das autoras reflete a defesa de uma tese a muito consolidada: "o ensino da oralidade não pode ser visto isoladamente, isto é, sem relação com a escrita" e o professor "precisa valorizar a linguagem presente nos textos falados pelos alunos como ponto de partida para a reflexão sobre a língua materna". (FÁVERO, ANDRADE e AQUINO, 2012. p. 15 e 120, respectivamente.). Dessa 
forma, podemos dizer que o foco no trabalho proposto por elas é que, a partir de uma situação comunicativa real, os alunos tenham a oportunidade de ouvir o dito (a partir de gravação, por exemplo), refletir sobre os usos linguísticos apresentados e realizar uma retextualização para observar diferenças e semelhanças com a escrita, bem como seu oposto (partir da escrita para o oral, por exemplo). Somente a partir daí é que os discentes entenderão as marcas da oralidade na escrita, ou as marcas da escrita na oralidade, como uma escolha do sujeito enunciador e não como fruto do acaso.

Para Melo, Marcuschi e Cavalcante (2012), o aluno só será competente na análise de textos orais quando souber relacionar aspectos linguísticos, paralinguísticos e extralinguísticos conjuntamente para a construção de significado. Sintetizamos, a seguir, os apontamentos das autoras sobre esses aspectos.

\section{Tabela 6: Aspectos a serem considerados no ensino do oral}

\begin{tabular}{l|l|l}
\hline \multicolumn{1}{c|}{ Aspectos linguísticos } & Aspectos paralinguísticos & \multicolumn{1}{|c}{ Aspectos extralinguísticos } \\
\hline - Marcadores conversacionais & - Prosódia. & - Número de participantes \\
(bom; bem; olha; então; sim, & - Ritmo. & envolvidos na interação. \\
mas...entende?; percebe?; & - Entonação. & - Grau de conhecimento e de \\
intimidade entre os sujeitos. \\
viu?; visse?) & - Intensidade & - Nível de planejamento da \\
- Repetições e paráfrases. & - Tom e volume da voz. & comunicação (preparada \\
- Correções e digressões. & - Aspectos cinésicos: relação & previamente ou não). \\
- Frases feitas, lugares-comuns. & entre palavra e corpo & - Temática abordada pelos \\
- Idiomatismos e provérbios. & (olhares, posturas, & interlocutores. \\
- Atos de fala. & expressões faciais, & \\
- Estratégias de polidez. & gestualidade corporal). & \\
\hline
\end{tabular}

(Fonte: MELO, MARCUSCHI e CAVALCANTE, 2012.)

A proposta trazida por elas evidencia a necessidade de um ensino que estimule a reflexão sobre todos os aspectos envolvidos na interação. As autoras enfatizam, no entanto, que não basta apenas apontar se há ou não cada um desses elementos no discurso, pois o foco é compreender qual o papel que estes usos desempenham no interior de uma prática comunicativa concreta. O objetivo no ensino seria, então, levar o aluno a "elaborar uma associação entre os fenômenos que se manifestam na superfície textual e as motivações sociais, culturais, situacionais, cognitivas subjacentes às práticas sociais do discurso oral." (MELO, MARCUSCHI e CAVALCANTE, 2012, p. 99). 
Para exemplificar, as autoras (MELO, MARCUSCHI e CAVALCANTE, 2012) citam um gênero também pertencente ao universo da TV: a entrevista. Para elas, embora seja importante retomar as características do gênero, evidenciando sua forma composicional, conteúdo temático e estilo, as semelhanças e diferenças dos subgêneros (entrevista jornalística, entrevista científica, entrevista médica, entrevista de emprego) e os interlocutores envolvidos, é fundamental levar o aluno a perceber o objetivo que essa entrevista desempenha dentro de um dado contexto social. Assim, analisando o papel das entrevistas dentro de uma reportagem ou noticiário de TV, as autoras mostram que elas são feitas apenas para confirmar uma tese já apresentada, portanto as opiniões dos entrevistados funcionam como mera ilustração do exposto e, assim, não evidenciam o que o entrevistado teria de singular. Em um documentário, no entanto, o papel que este sujeito desempenha assumiria outra função:

(...) em uma reportagem sobre a alta de preços, as entrevistas com os transeuntes estão ali inseridas apenas para confirmar o que a notícia já adiantou: o aumento do valor da mercadoria e, provavelmente, a queixa da população. Justamente por serem entrevistadas não em sua singularidade, mas pela categoria que representam dentro do contexto da reportagem, as falas das pessoas nas entrevistas tendem a reproduzir as mesmas informações.

Já no gênero documentário, que costuma ter um tempo de produção maior, é mais fácil se delegar ao próprio sujeito entrevistado a responsabilidade de sua mise-en-scène. Quando isso acontece, a entrevista ganha densidade e a pessoa é capaz de se mostrar em toda a sua singularidade, ambiguidade e contradição.

(MELO, MARCUSCHI e CAVALCANTE, 2012, p. 101).

Como proposta para o ensino, as autoras apresentam ainda uma sequência didática cujos objetivos seriam (1) reconhecer algumas das características e funções de uma entrevista na modalidade oral e outra na escrita; (2) discutir com os alunos sobre as relações entre o oral e o escrito nesse gênero; (3) refletir sobre aspectos ligados à retextualização e, por fim, (4) produzir uma entrevista oral e, depois, retextualizá-la para a escrita. $\mathrm{O}$ trabalho proposto seria desenvolvido em 10 aulas.

Santos, Costa-Maciel e Barbosa (2012) também apresentam uma proposta para trabalhar com um gênero da esfera jornalística: a notícia do rádio. $O$ trabalho apresentado pelas autoras, evidencia o passo-a-passo da ação didática, que inclui o levantamento do conhecimento prévio dos alunos sobre o gênero, realização de 
enquete oral para a escolha do nome do programa de rádio a ser criado pela turma, discussão sobre os papéis sociais desempenhados por cada um na rádio escolar, estudo do gênero notícia no contexto do rádio, escrita da notícia, considerando que ela será falada, produção oral gravada, análise da gravação para discutir as especificidades da oralidade e da escrita e, por fim, a inauguração do programa de rádio.

Nesta proposta, no entanto, há pouca clareza sobre como o docente conseguirá efetivar a divulgação desse trabalho na escola, visto que os recursos técnicos para isso demandam recursos nem sempre disponíveis para o professor. De qualquer forma, o encaminhamento é válido especialmente por oportunizar uma reflexão que coloca as modalidades oral e escrita lado a lado, cada uma com sua especificidade, mas também agindo de forma integrada.

Os estudos mostrados até o presente momento delineiam, em grande medida, como pode ser o trabalho com língua oral na escola. De forma geral, podemos concluir que esse ensino deve:

(a) partir de uma situação comunicativa oral real;

(b) explorar as relações entre as duas modalidades da língua (oral e escrita), evidenciando suas especificidades e seus entrelaçamentos;

(c) evidenciar questões ligadas à sua constituição linguística (gramatical, inclusive), mas sempre em relação com os aspectos interacionais (sujeitos envolvidos, condições de produção, intenções comunicativas etc).

(d) contextualizar o discurso, evitando o uso de textos artificiais e descolados da vida.

(e) partir de situações cotidianas de conversação e chegar a um estudo de gêneros orais formais públicos.

Nas reflexões propostas pelos pesquisadores citados está claro que não se trata de ensinar "o oral", suas marcas e características, como algo pronto, como uma "gramática" a ser dada. Em todos os estudos mostrados, o trabalho parte da vida, seja pela análise de conversas cotidianas, seja pela exploração mais detalhada de um gênero discursivo presente na escola (exposição, relato de experiência, seminário...) ou na vida pública (debate, entrevista, notícia televisiva...). 
Como essas reflexões foram incorporadas nas propostas didáticas do LDP é o que abordaremos no próximo tópico.

\subsubsection{Recepção nos Livros Didáticos Português}

Para Serafim, a publicação dos PCN fez crescer a demanda de pesquisas em torno dos estudos da modalidade oral da língua, favorecendo mudanças na forma como o professor encara esse ensino. Segundo ela, "não cabe mais à escola apenas ensinar o aluno a ler e escrever, é preciso instruí-lo a relacionar a língua às práticas sociais dos indivíduos". (SERAFIM, 2011, p. 28).

Para investigar esse ensino, o livro didático de português foi tomado como objeto de estudo por diversos pesquisadores.

Marcuschi (2003), ao analisar um LDP, buscou apontar, por um lado, as concepções teóricas que subjazem à sua proposta e, por outro, sugerir encaminhamentos para o trabalho com a oralidade.

Em um primeiro momento, afirma que em grande parte deles a concepção teórica subjacente às propostas reflete uma visão de língua que se caracterizaria por "(a) um conjunto de regras gramaticais (ênfase no estudo da gramática), (b) um instrumento de comunicação (visão instrumental da língua) e (c) um meio de transmissão de informação (sugerindo a língua como código)." (MARCUSCHI, 2003, p. 22)

Como resultado dessa concepção, a análise feita aponta para um ensino que tem como base atividades gramaticais isoladas, tratadas de forma pouco reflexiva, exercícios de compreensão leitora com foco na localização e cópia, além de propostas de produção textual que se fixam em estereótipos ${ }^{24}$.

Observando os LDP (...), constata-se que eles, de uma maneira geral, tomam a língua como um simples instrumento de comunicação não problemático capaz de funcionar com transparência e homogeneidade. A dar crédito aos livros didáticos, a língua é clara,

\footnotetext{
${ }^{24} \mathrm{Em}$ nossa análise preliminar de algumas obras aprovadas no PNLD 2015, verificamos a permanência de práticas semelhantes às declaradas pelo autor em 2003, o que aponta para a ainda atual necessidade de se refletir sobre as práticas propostas no LDP para o ensino de língua.Ressaltamos, no entanto, que alguns LDP's apresentam propostas pertinentes, mais ligadas a uma concepção de língua que considera seu aspecto interativo e dialógico, resultado de uma atividade particular, mas ao mesmo tempo social e histórica.
} 
uniforme, desvinculada dos usuários, descolada da realidade, semanticamente autônoma e a-histórica. Difícil, pois, achar um lugar e um papel para a oralidade num contexto teórico destes. Este é o desafio dos próximos passos a serem dados.

(MARCUSCHI, 2003, p. 23, grifo nosso)

Considerando uma formação integral do aluno, entendemos que um ensino nessas bases pode consolidar uma visão distorcida da língua, favorecendo a perpetuação de preconceitos linguísticos (BAGNO, 1999, 2000, 2007; BORTONIRICARDO, 2004; ILARI\& BASSO, 2006), bem como a limitação que o falante/escrevente pode ter de sua própria língua, em seus diferentes usos no interior de cada prática social de que faz parte.

Marcuschi (2003) evidencia suas principais críticas ao tratamento dado à oralidade nos LDP do ensino fundamental ${ }^{25}$, como mostramos a seguir:

\section{Tabela 7-Tratamento da oralidade no LDP: problemática}

Terminologia pouco definida.

$\checkmark$ Ausência de concepção de língua falada.

$\checkmark$ Tendência a dicotomizar escrita e fala, associando-a a ideia de língua padrão e nãopadrão, respectivamente.

$\checkmark$ Língua falada tratada como questão lexical apenas.

$\checkmark$ Reescrita de expressões descontextualizadas.

$\checkmark$ Atividades de oralização da escrita.

$\checkmark$ Ausência de propostas de audição de falas reais, fora do contexto escolar.

$\checkmark$ Falta de consistência no tratamento das relações entre fala e escrita.

$\checkmark$ Orientação de propostas que levam à discriminação das variedades regionais ou populares.

$\checkmark$ Reescrita de fala que não levam em conta o valor semântico da mudança.

(Fonte: MARCUSCHI, 2003. Síntese nossa.)

Antunes (2003), na mesma direção, aponta problemas semelhantes, evidenciando a quase omissão da fala como objeto de ensino e, mostrando que, quando isso é feito, há uma visão equivocada que trata a fala como o lugar do erro e uma concentração de propostas que focam apenas em registros orais coloquiais, como a "conversa", a "troca de ideias" e a "explicação para o colega". Em suma, a oralidade não é, de fato, tomada como objeto de ensino.

\footnotetext{
${ }^{25} \mathrm{O}$ autor não determina se suas reflexões estão ligadas ao Ensino Fundamental I ( $1^{\circ}$ ao $5^{\circ}$ ano) ou II (6ำ ao $9^{\circ}$ ano). Considerando nossa experiência profissional com livros didáticos, acreditamos que suas considerações sejam válidas e pertinentes aos dois segmentos de ensino.
} 
Teixeira (2012) evidencia outra questão significativa: a localização em que as propostas de oralidade são apresentadas no interior da obra didática reflete 0 pouco caso - no que se refere à importância desse eixo de ensino em comparação aos demais - que se dá para o trabalho com oralidade.

Bastaria pensar nos livros didáticos que deslocam para o final das lições os exercícios de expressão oral, a fim de que o professor se sinta mais à vontade para "pulá-los" se assim o desejar, como me explicou recentemente uma editora experiente.

(TEIXEIRA, 2012, p. 241)

Costa, investigando sobre a oralidade de livros didáticos de português, voltados para o Ensino Fundamental I ( $1^{\circ}$ ao $5^{\circ}$ ano), com vistas a identificar se as atividades orais propostas contribuíam para a apropriação, pelo aluno, de práticas discursivas efetivas de uso da oralidade, concluiu que o trabalho ainda era muito pouco consistente, evidenciando, assim, que "ainda há um percurso a ser construído no sentido de efetivar o trabalho com a oralidade em sala de aula como um eixo de ensino de Língua Portuguesa, sobretudo, no que concerne aos livros didáticos de Língua Portuguesa" (COSTA, 2006, p. 9).

Barros-Mendes (2005), em sua tese de doutoramento, também pesquisou essa questão e concluiu, a partir da análise de seis coleções (PNLD 2002 e 2005) voltadas para o Ensino Fundamental II ( $6^{\circ}$ ao $9^{\circ}$ ano), que o tratamento didático da oralidade ocorre de duas formas: ou a oralidade é vista como meio, ou é tomada como objeto de ensino. No primeiro caso, o foco recai no uso do discurso oral para intermediar as interações entre professor e aluno na exploração de atividades ligadas à leitura e compreensão textual, produção de textos escritos e discussão de aspectos gramaticais. No segundo, o objetivo é tomar os gêneros discursivos, ligados à situação formal pública - como debate, entrevista, palestra, seminário e outros -, para o ensino sistemático da oralidade.

Magalhães (2007) já aponta um problema ligado à concepção da oralidade, visto que constatou que este conceito é entendido de forma diferente, tanto em dois documentos oficiais analisados - PCN e Guia do PNLD 2005 - como em livros didáticos de português de Ensino Fundamental aprovados pelo Programa Nacional do Livro Didático (PNLD) de 2005. Como resultado disso, concluiu que ainda há uma 
supervalorização do trabalho da escrita na escola em detrimento do trabalho com a oralidade.

Após avaliar os LDP's voltados para o ciclo de alfabetização e aprovados no PNLD 2007, Rojo também conclui que:

Quanto à abordagem adotada para o desenvolvimento da linguagem oral, também se constatam convergências nas propostas. Prevalecem as atividades de uso da linguagem oral em sala de aula, para que os alunos manifestem seu ponto de vista sobre determinado texto ou assunto para toda a turma ou para pequenos grupos de trabalho, realizem entrevistas ou recontem histórias lidas. Dessa forma, nenhum dos livros se diferenciou dos demais quanto a pouca atenção dada a reflexão sobre as características e os usos que são feitos de textos orais produzidos em diferentes espaços sociais. Como lacuna comum, observa-se que mesmo as obras que possibilitam o uso da linguagem em sala de aula restringem sua exploração ao contexto escolar.

(ROJO, 2006, p.55)

O foco apenas em temas - orientação para o que dizer - e menos no trabalho sistemático de um gênero social e seu funcionamento é o que evidencia Bunzen (2013) ao tratar sobre o ensino do gênero debate em três coleções aprovadas no PNLD 2011. O autor afirma que nessas obras "há poucas tarefas que propõem reflexões que desenvolvam as capacidades linguístico-discursivas ou até mesmo os elementos prosódicos e não linguísticos”. (BUNZEN, 2013, p. 381)

São diversos os trabalhos que, analisando o LDP, no que tange às propostas de oralidade, evidenciam diversas lacunas. Para Rojo (2003), esses resultados, materializados nos enunciados que compõem os LDP's, são reflexos da falta de conhecimento de autores e editores sobre como ensinar e como aprender a linguagem oral. A autora chega a essa conclusão ao perceber que esses profissionais têm pouca clareza sobre como deve ser o trabalho com oralidade.

Na mesma direção, Cavalcante e Melo (2006, p. 182), referindo-seaos LDP do ensino médio, vão afirmar que "os autores de manuais didáticos, em sua maioria, ainda não sabem onde e como situar o estudo da fala."

Se, por um lado, considerar o maior ou menor grau de preparo do autor/editor é significativo, por outro, interessa saber a percepção do professor frente às 
propostas de oralidade presentes no LDP. Em investigação sobre o ensino da oralidade na prática docente, Costa-Maciel (2013) revela que muitas vezes o próprio professor não tem clareza do que considerar como "trabalho com oralidade" em um livro didático.

Em seu estudo, a autora (COSTA-MACIEL, 2013) traz o depoimento de docentes que confundem a interação em sala de aula - leitura em voz alta, discussão em grupos, participação oral em resposta a alguma atividade, dentre outras - com o desenvolvimento da oralidade, como prática social. Não percebem, assim, a importância de planejar o que será dito, de organizar a fala em um dado gênero discursivo, de considerar quais recursos linguísticos são mais adequados à situação e de observar as diversas condições de produção do discurso, especialmente no que se refere aos interlocutores envolvidos.

Trabalhos em nível de mestrado e doutorado que tratem a questão dos gêneros orais em obras didáticas para o ensino médio são menos recorrentes. $A$ maior parte das pesquisas voltadas para este estudo está ligada ao Ensino Fundamental, tanto do primeiro ( $1^{\circ}$ ao $5^{\circ}$ ano), quanto do segundo ciclos (6ำ ao $9^{\circ}$ ano).

É importante destacar, no entanto, que o artigo de Cavalcante e Melo (2006) tem esse nível de ensino como foco central para discutir a questão da oralidade. Nele, as autoras apontam, para o ensino médio, um cenário semelhante ao que observamos no Ensino Fundamental: o pouco espaço que a oralidade tem tido no LDP para contribuir para o desenvolvimento de práticas ligadas a essa modalidade de ensino.

Considerando a problemática apresentada, alguns autores buscam apontar caminhos para o trabalho com a oralidade no LDP.

Marcuschi (2003, p. 33-34), por exemplo, elenca sete aspectos que poderiam ser aproveitados no encaminhamento das propostas didáticas, as quais podem ser sintetizadas em:

(1) audição de fitas com falas das mais diversas regiões brasileiras; 
(2) debate sobre a diversidade linguística, no intuito de afastar o problema do preconceito e de mostrar como a fala pode contribuir para a formação de identidades;

(3) análise da polidez e sua organização na fala;

(4) reflexão sobre o papel dos interlocutores e dos gêneros para compreensão das características do discurso;

(5) discussão sobre as formas de desenvolver os temas e suas diferenças em relação à escrita;

(6) identificação de alguns aspectos típicos da produção oral (hesitações, marcadores conversacionais, repetições, modalizadores, correções, etc);

(7) análise de características mais marcantes da estrutura linguística na fala (cortes e retomadas, por exemplo).

(8) atividades de retextualização (da fala para escrita e da escrita para a fala).

(MARCUSCHI, 2003, p. 33-34. Trechos selecionados.)

O enfoque proposto pelo autor não deveria prescindir, portanto, da observação de aspectos linguísticos para análise da oralidade: diferenças dialetais, variação, polidez, especificidades da produção oral, relação entre interlocutores no interior de uma interação verbal, dentre outros. Enfim, a proposta é de um trabalho que vise não uma gramaticalização do oral, mas de uma reflexão situada sobre a língua falada.

Cavalcante e Melo (2006) também reafirmam que discutir sobre preconceito e discriminação linguística é essencial num trabalho sobre oralidade. As autoras reforçam, ainda, que não basta ao LDP dar ao aluno apenas o nome do gênero a ser produzido $^{26}$, pois é preciso levá-lo a compreender os contextos sociais de uso dos gêneros apresentados.

Pensando em auxiliar o professor do ensino médio na tarefa de refletir sobre a oralidade com seus alunos, as pesquisadoras irão propor algumas atividades com gêneros orais ligados à mídia, o que se justifica por dois motivos: por todos estarmos sujeitos à ação da mídia e pela influência que "o poder da mídia [exerce] na constituição da identidade do aluno". (CAVALCANTE e MELO, 2006, p. 183)

\footnotetext{
${ }^{26}$ A esse respeito, conferir o estudo de Silva e Mori-de-Angelis (2003) sobre como a oralidade é tratada nos LDP's aprovados pelo PNLD 2002, voltados para o Ensino Fundamental II (6음 ao 9o anos).
} 
As autoras orientam então algumas práticas possíveis: análise do "diálogo" presente em gêneros diversos (entrevista, debate, mesa-redonda e monólogo), visando observar suas especificidades, reflexão sobre o papel dos interlocutores no interior de cada um desses gêneros, discussão acerca das estratégias de polidez utilizadas por eles no momento de interação; observação de marcas de oralidade (hesitação, repetição, tom mais elevado visando a um propósito, alongamento de vogais com fim específico, sobreposição de vozes, marcadores conversacionais, truncamentos, dentre outros) no discurso, etc.

Além dessas práticas, Cavalcante e Melo (2006) ainda sugerem o trabalho com novelas, seja para estimular uma discussão sobre problemas sociolinguísticos e discursivos (por exemplo, quando há uma padronização linguística de personagens de níveis sociais e de escolarização diferentes), seja para propor uma atividade de retextualização (da escrita para a fala) ao trabalhar com roteiros de novelas, fato que propiciaria a oportunidade de discutir a relação entre fala e escrita.

Por fim, as pesquisadoras ainda reforçam que a observação da oralidade típica da TV permitiria criar situações de escuta em que os alunos pudessem refletir sobre "estratégias diferenciadas de compreensão de textos orais produzidos em contextos discursivos mais públicos". (CAVALCANTE e MELO, 2006, p. 197)

As autoras deixam claro que seu foco não está na produção do texto oral, mas em sua análise:

O mote do trabalho ora proposto se baseia em como ler os textos da televisão, não necessariamente como produzi-los, pois é mais importante para o aluno educar o olhar e identificar nos gêneros da mídia marcas de manipulação, de disseminação de ideologias, de discriminação e de preconceito, do que saber escrever uma noticia ou reportagem.

(CAVALCANTE; MELO, 2006, p. 186)

Além disso, reforçam que a escolha dos programas televisivos deve ser feito considerando o que os alunos realmente assistem, observando-se, assim, a familiaridade dos alunos com o que é veiculado na TV. Em outras palavras, o professor deve fazer uma sondagem para verificar o que é mais relevante para os discentes naquele momento singular. 
Vale ressaltar, ainda, que a proposta extrapola o espaço físico do LDP ao propor a análise da oralidade presentes em programas televisivos. Entendemos, pois, que essas proposições dadas no interior do livro didático devem se dar no sentido de apresentar um caminho possível, com algumas dicas de encaminhamento, mas devem igualmente permitir ao aluno/professor, envolvidos na situação concreta em que as atividades realizar-se-ão, definir seus próprios passos, advindos da singularidade do evento. Além disso, vemos como útil pensar também em propostas efetivas de produção oral, uma vez que as análises são, em nosso ponto de vista, apenas um meio para chegar a concretização maior de uso efetivo da língua; da produção situada em um contexto socio-histórico particular.

Por último, mas não menos importante, é fundamental citar o trabalho dos pesquisadores de genebra que divulgaram diversas pesquisas ${ }^{27}$ sobre a proposição de sequências didáticas para o ensino de gêneros orais formais públicos (como exposição oral, entrevista radiofônica, debate e seminário), as quais influenciaram a produção de LDP's em diversos níveis de ensino ${ }^{28}$.

Os autores não só defendem que a oralidade pode ser ensinada, mas também evidenciam o que priorizar e como isso deve ser feito.

O enfoque em "o que ensinar" recai sobre os gêneros orais formais públicos - como dito anteriormente - uma vez que em algum momento, na vida prática do discente, ele irá fazer uso desses gêneros. A ideia é, pois, trabalhar com gêneros de circulação social para que o ensino esteja conectado com uma prática situada de uso da língua.

Já no que se refere ao "como ensinar", a proposta dos autores é que o ensino esteja pautado em um conjunto de ações sequenciadas, a saber: (1) "apresentação da situação", para dar ciência ao aluno sobre os objetivos e principais passos que serão trilhados no ensino; (2) "produção inicial", que teria como objetivo evidenciar para o professor o que o aluno já sabe para, a partir daí, definir estratégias de ensino; (3) "módulos de ensino", ocasião em que os alunos

${ }^{27}$ A esse respeito, conferir os trabalhos: Dolz\&Schneuwly, 1998, 2004b; Dolz, Schneuwly e Noverraz, 2004; Dolz, Schneuwly e Haller (2004); Dolz, Schneuwly, De Pietro (et al), (2004); Dolz, Schneuwly, De Pietro (2004).

${ }^{28}$ Apenas para citar como exemplo, das dez coleções aprovadas no PNLD 2015, oito faz menção à obra organizada por Dolz e Schneuwly "Gêneros orais e escritos na escola" (DOLZ \& SCHNEUWLY, 2004a). 
realizariam atividades e exercícios, de forma progressiva, a fim de que fossem, aos poucos, aprofundando seus conhecimentos; e, por fim, (4) "produção final", ocasião em que o aluno poderia colocar em prática o que aprendeu e o professor teria possibilidade de observar o progresso a que o discente chegou, comparando, para isso, a sua produção inicial com a produção final.

O esquema proposto para essas Sequências Didáticas (SD) pelos autores está representado na figura a seguir:

\section{Figura 2 - Esquema de SD proposto pelos pesquisadores de Genebra}

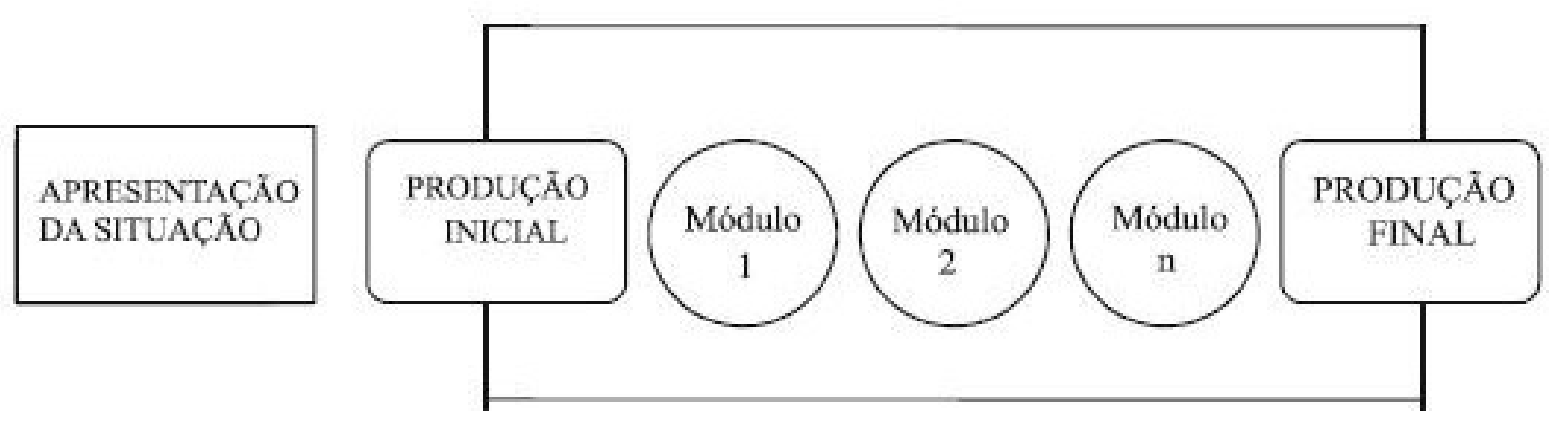

Fonte: DOLZ, SCHNEUWLY, NOVERRAZ, 2004b, p. 98.

A proposta dos autores é relevante se consideradas como base para se pensar o ensino, não como uma camisa-de-força. Dessa forma, a ideia é favorecer o trabalho com oralidade na escola de forma sistemática, a fim de garantir a produção de textos significativos e relevantes no interior de uma prática discursiva eficiente. Entendemos que, a partir dessa proposição, o professor deve, assim como quando faz uso do livro didático, observar a singularidade do evento e, a partir daí, ampliar e rever sua forma de ação pedagógica, de forma consciente e responsável.

Neste tópico, buscamos apontar as pesquisas que tiveram como objetivo evidenciar o trabalho com oralidade tanto pensando em propostas para seu ensino, quanto em reflexões sobre sua inserção no LDP.

A partir desses estudos, pudemos compreender o diálogo entre teoria e prática, ou seja, entre os conceitos e concepções para o estudo da oralidade, 
apresentado no capítulo inicial de nossa pesquisa, e sua efetiva incorporação no discurso pedagógico.

Trataremos de explicitar, no próximo capítulo, as concepções teóricas que entendemos como fundamentais para nosso estudo e que se encontram, de alguma forma, nas bases que fundamentam a pesquisa de grande parte desses estudiosos: a teoria dialógica do discurso. 


\section{CAPÍTULO 2}

\section{ORALIDADE NA TEORIA DIALÓGICA DO DISCURSO}

A língua no processo de sua realização prática não pode ser
separada do seu conteúdo ideológico ou cotidiano.

(VOLÓCHINOV, 1929/2017, p. 181)

Tratamos, anteriormente, sobre o percurso empreendido no campo dos estudos sobre oralidade, evidenciando, historicamente, a constituição desse conceito e como o gênero oral entra no ensino de língua portuguesa.

Neste capítulo, passamos a aprofundar os conceitos de interação, enunciado concreto, esfera, gêneros do discurso, entonação e valoração da linguagem na perspectiva da teoria bakhtiniana, os quais podem contribuir para a reflexão de língua enquanto signo ideológico e voltado para a vida.

Além disso, nosso objetivo é recuperar conceitos que têm sido usados como base para pesquisas sobre oralidade, como é o caso dos gêneros do discurso, bem como diferenciar alguns termos que lexicalmente podem remeter a teorias diversas, como ocorre com as palavras "diálogo" e "interação". 


\subsection{Interação verbal e diálogo}

Os estudos bakhtinianos, embora não tenham se preocupado em apresentar uma "definição" de oralidade, têm servido de base para o desenvolvimento de diversas propostas didáticas de LDP's produzidos no final do século XX e nas duas primeiras décadas do século XXI, em geral fazendo uso do conceito de gêneros orais formais públicos, sobre o qual falaremos adiante.

Considerando que nossa pesquisa tem como enfoque o estudo do gênero debate no livro didático de ensino médio, é importante frisar o que, nesta teoria, entende-se por "interação verbal" e de que forma esse conceito diferencia-se do apresentado em teorias anteriores.

Os estudos da Análise da Conversação entendem a interação como um processo do ato conversacional, ou seja, da conversa face a face. As pesquisas advindas dessa linha teórica buscam evidenciar o comportamento verbal dos locutores no momento de realização do discurso e as estratégias utilizadas por eles para a efetivação do diálogo. Portanto, tanto a situação de produção, quanto as características dos participantes são consideradas.

Para esta teoria, ao enunciar, o locutor não apenas transmite uma mensagem, mas faz isso de forma a considerar quem é seu interlocutor, quais as intenções que este tem com sua fala, que estratégias foram utilizadas para organizar seu discurso e de que forma ele próprio, como enunciador, deve encaminhar sua conversa para levar o outro a cooperar no processo interacional. Brait (2003, p. 222) afirma que "a percepção desses componentes e a maneira de lidar com eles constituem a dinâmica da interação".

Em Marxismo e Filosofia da Linguagem, Volóchinov (1929/2017) apresenta uma estratégia para o estudo da língua a partir de um "método sociológico". Para ele, a análise da interação verbal, associada às situações de produção é o ponto de partida para compreender as formas de uso da língua.

Mas o que seria interação verbal nesta perspectiva?

Apontando para uma visão mais abrangente do termo, o autorentende que ainteração é a própria essência da linguagem, é um fenômeno social que se realiza através de enunciados.Segundo ele, 
O diálogo, no sentido estrito da palavra, é somente uma das formas da interação discursiva, apesar de ser a mais importante. No entanto, o diálogo pode ser compreendido de modo mais amplo, não apenas como a comunicação direta em voz alta entre as pessoas face a face, mas como qualquer comunicação discursiva, independente do tipo.

(VOLÓCHINOV, 1929/2017, p. 219)

Como resultado dessa visão, o autor incorpora a comunicação escrita como elemento da interação verbal, evidenciando que o enunciador não apenas interage com um interlocutorempresença (no caso do texto oral) ou com seu leitor (no caso do texto escrito), mas também se relaciona com o seu tempo de produção, com outros interlocutores e com a esfera em que o discurso é produzido.

Um livro, ou seja, um discurso verbal impresso também é um elemento da comunicação discursiva. (...) [Ele] é inevitavelmente orientado para discursos anteriores tanto do próprio autor quanto de outros, realizados na mesma esfera, e esse discurso verbal parte de determinada situação de um problema científico ou de um estilo literário. Desse modo, o discurso verbal impresso participa de uma espécie de discussão ideológica em grande escala: responde, refuta ou confirma algo, antecipa as respostas e críticas possíveis, busca apoio e assim por diante.

(VOLÓCHINOV, 1929/2017, p. 219)

O diálogo, então, antes entendido apenas em sua forma composicional, que resulta da interação face a face ou, por exemplo, do registro escrito de conversa entre personagens em obras literárias, adquire um novo sentido:é entendido como a relação de valor estabelecida entre enunciados, que ocorre entre interlocutores situados em um tempo e espaço sócio-historicamente definidos.

A necessidade de se considerar não apenas a estrutura composicional para a compreensão do enunciado, já estava presente no texto de 1926, Palavra na vida e palavra na poesia ${ }^{29}$ (VOLÓCHINOV,1926/2013), cujo enfoque recai sobre a leitura de obras artísticas. Neste estudo, o autor busca mostrar que a arte não pode ser considerada como algo não sociológico, ou seja, um discurso independente da

\footnotetext{
${ }^{29}$ Apesar de no meio acadêmico, este texto circular, na tradução de 1976, com o nome de "Discurso na vida e discurso na arte", optamos por manter aqui o título que aparece na edição organizada pelo Prof. Dr. Wanderlei Geraldi (VOLÓCHINOV, 1926/2013), visto que os fragmentos citados encontramse nesta edição.
} 
sociologia. Para ele, "a arte é eminentemente social", pois o estético é apenas "uma variedade do social"(1926/2013, p. 74). Está, portanto, dentro dela e não fora.

Nesse estudo, Volóchinov(1926/2013) propõe uma análise sociológica aplicada à Teoria da Arte e, para tanto, rejeita dois pontos de vista:

$1^{\circ}$ ) Estudar somente a obra de arte - o criador e seus contempladores estão fora.

$\left.2^{\circ}\right)$ Estudar somente a mente do criador e do contemplador - observação apenas das experiências de criação e contemplação.

Esses dois olhares (foco no artefacto material e foco na psiquê individual) não são adequados, pois "pecam em um mesmo erro: tentam encontrar uma parte na totalidade" (1926/2013, p. 75). Para os estudiosos, não é possível compreender verdadeiramente uma obra artística sem levar em conta os aspectos sociais que a envolvem.

Apesar de o autor tratar, nesse texto, de aspectos ligados à arte e a literatura, é possível depreender, em outras passagens do conjunto das obras do círculo de Bakhtin - como as mencionadas a seguir -, que a questão do diálogo, ou melhor, das relações dialógicas entre enunciados, e a necessidade de se considerar o discurso em sua situação concreta de uso são aspectos que envolvem não apenas o discurso literário, mas qualquer discurso produzido na vida.

Toda a vida da linguagem, seja qual for o seu campo de emprego (a linguagem cotidiana, a prática, a científica, a artística etc), está impregnada de relações dialógicas.

(BAKHTIN, 1929/2008, p. 209)

As formas desse elo [entre a interação concreta, a situação extraverbal e situação mais ampla] são diversas e cada uma delas condiciona as diferentes significações que as situações adquirem em momentos variados (...). A comunicação discursiva nunca poderá ser compreendida nem explicada fora dessa ligação com a situação concreta.

(VOLÓCHINOV, 1929/2017, p. 220)

(...) toda expressão tem uma orientação social. Em consequência, ela é determinada pelos participantes do acontecimento constituído pela enunciação, participantes próximos e remotos. A interação entre os participantes desse acontecimento dá forma à enunciação, faz 
com que soe de uma determinada maneira e não de outra: como pedido peremptório ou como uma súplica, fazendo valer os próprios direitos ou suplicando um favor, com um estilo simples ou altissonante, com segurança ou com timidez.

Precisamente essa dependência da enunciação às circunstâncias concretas em que ocorre tem para nosso exame um significado de extrema importância.

(VOLÓCHINOV, 1930/2013a, p. 149)

Os excertos apresentados de outras três obras do círculo bakhtiniano ${ }^{30}$ Problemas da poética de Dostoievski, Marxismo e Filosofia da Linguagem e A construção da enunciação ${ }^{31}$ e outros ensaios - reforçam o caráter dialógico e social da linguagem, bem como a relevância das situações concretas para construção desse dizer único.

Os estudos do círculo de Bakhtin evidenciam, pois, uma noção de linguagem que é social, visto que só ocorre entre indivíduos situados em um tempo e um espaço singulares, atuando de forma ativa e responsiva em toda a cadeia da comunicação verbal.

Para qualquer estudo que se faça da língua - seja oral ou escrita - trabalhar a linguagem é também explorar a realidade social que a envolve. Interessa-nos saber se/como o LDP de EM faz isso.

No que tange ao conceito de diálogo, faz-se necessário retomar a reflexão proposta por Faraco ao apontar que esse termo poderia, erroneamente, ser associado à ideia de consenso, o que fugiria aos propósitos dos estudiosos do círculo bakhtiniano. Segundo o autor, como as relações dialógicas acontecem em uma situação social real, "delas pode resultar tanto a convergência, o acordo, a

\footnotetext{
${ }^{30}$ A expressão "círculo de Bakhtin/bakhtiniano" é usada para fazer referência a um grupo de intelectuais que se reunia regularmente, entre os anos de 1919 e 1929, com a intenção de discutir e debater sobre temas diversos. Como participavam desse estudo pessoas com formações diversas, constituiu-se como um grupo multidisciplinar. Integraram esse "círculo":Matvei I. Kagan (filósofo), Ivan I. Kanaev (biólogo), Maria V. Yudina (pianista), Lev. V. Pumpianski (professor e estudioso de literatura), Valentin N. Voloshinov (linguista), Pavel N. Medvedev (professor de literatura) e Mikhail M. Bakhtin (filósofo), esses três últimos, mais conhecidos no ocidente.

${ }^{31} \mathrm{O}$ uso do termo "enunciação" presente em algumastraduções das obras do Círculo (BAKHTIN, 1979/2011a; VOLÓCHINOV, 1930/2013), remete a uma distinção entre as palavras "enunciado" e "enunciação", esta se referindo ao momento de produção do discurso e àquela ao produto resultante desse ato. Por entender, como Paulo Bezerra (BAKHTIN, 1979/2011a, p. 261, nota do tradutor) que "Bakhtin não faz distinção" entre esses termos, uma vez que um está imbricado no outro, optamos por usar o termo "enunciação" apenas nas citações diretas, deixando o termo "enunciado", nesta tese, entendido como um dizer situado em um momento específico e, portanto, não apartado dele.
} 
adesão, o mútuo complemento, a fusão, quanto a divergência, o desacordo, o embate, o questionamento, a recusa."(FARACO, 2009, p. 68)

Temos, assim, construída a noção de diálogo como o espaço de luta de classes e do embate de vozes sociais, que ocorre no interior de uma interação verbal - oral ou escrita -, considerada enquanto processo verbal e social.

\subsection{Enunciado concreto}

Mas qual o papel que assume esse dizer no centro de uma interação verbal?

Para compreender essa questão é necessário retomar a crítica apresentada por Volóchinov(1929/2017) em Marxismo e Filosofia da Linguagem no que se refere aos estudos ligados tanto à vertente estruturalista, que trata a língua como abstração, quanto às relacionadas à estilística formalista, que têm o sujeito como centro da produção verbal, valorizando, portanto, a subjetividade na linguagem.

Para a primeira corrente - o objetivismo abstrato -, a língua é um sistema estável e imutável de formas linguísticas. Segundo essa linha de pensamento, estariam concentrados na estrutura da língua (fonética, lexical, morfológica, sintática) todos os recursos necessários para que a comunicação ocorresse. Como resultado disso, o sujeito não é entendido como necessário ou participante do processo de comunicação. Seu papel é o de apenas fazer uso dos signos linguísticos que fazem parte de um sistema fechado, que já vem pronto.

Volóchinov (1929/2017) critica essa abstração, argumentando que a palavra só assume seu verdadeiro sentido quando em uso, em contato com esse sujeito que produz o discurso e em relação com a situação social e histórica em que este se realiza. É nesse sentido que afirma:

Desse modo, a consciência linguística do falante e daquele que escuta e compreende não lida na prática ou na fala viva com um sistema abstrato de formas linguísticas, mas com a linguagem no sentido do conjunto de diferentes contextos possíveis em que essa forma linguística pode ser usada. Para o falante nativo, a palavra se posiciona não como um vocábulo de dicionário, mas como uma palavra presente nos enunciados mais variados de combinação linguística $A, B, C$ etc., e como palavras de seus próprios enunciados multiformes de sua comunidade e das múltiplas enunciações de sua própria prática linguística. 
Como resultado dessa nova forma de entender a linguagem, o autor vai reforçar a ideia de que existe um vínculo estreito entre o discurso produzido e sua realidade histórica, social e ideológica, na qual o sujeito está situado. É o primeiro passo na direção de se considerar a relação entre linguagem e sujeito.

Para não ser mal compreendido, no entanto, o estudioso vaiapontar que apesar da importância em se considerar o sujeito, não é nele que está todo o centro de produção de sentidos da língua. É por esse motivo que trará suas considerações acerca da problemática presente em um pensamento que idealize o indivíduo.

Conforme essa segunda corrente do pensamento linguístico da época - o subjetivismo idealista -, a língua seria resultado do mundo interior do sujeito e, por isso, reflexo de um processo criativo engendrado por ele. Coloca-se sob o indivíduo toda a responsabilidade pelo dito, mas não se consideram as relações desse dizer com a situação social e histórica em que ele foi produzido.

Volóchivov (1929/2017) vai discordar do ponto de vista trazido por essa teoria ao mostrar que toda forma de expressão do sujeito não é interior, mas exterior, uma vez que se situa no meio social em que o indivíduo vive. Além disso, vai mostrar que o conteúdo ideológico das formas linguísticas não se localiza no psiquismo individual do sujeito - como defendia o subjetivismo idealista -, mas tem natureza social.

Para o autor, nem o objetivismo abstrato, nem o subjetivismo individualista conseguem dar conta da dinamicidade e do caráter social e histórico da língua. Por isso, opõe-se a uma visão monologizada de língua trazida por essas duas teorias (que evidenciam a oposição sistema linguístico $x$ subjetividade do sujeito, ambas entendendo a fala como individual) e propõem uma compreensão de linguagem mais ampla, uma síntese dialética, em que a fala - ou a expressão concreta de realização desse dizer - seja entendida na sua dimensão social, na sua relação entre interlocutores, tempo/ espaço e ideologias dentro de um contexto histórico e social mais amplo.

A linguagem, nessa concepção, tem uma natureza sócio-histórica, isto é, constrói-se no contexto em que se realiza, refletindo e refratando as ideologias que aí circulam. Para se considerar, portanto, a verdadeira substância da língua, importa antes considerar os fenômenos sociais por meio das interações, que os das 
condições psicofisiológicas do falante/produtor, ou o estudo de sistemas linguísticos abstratos, isolados da situação concreta de realização da língua.

Essa visão enunciativa de linguagem está no cerne dos estudos bakhtinianos e, em matéria de ensino, evidencia uma nova forma de tratar a linguagem. Assim, entendida como resultado da interação com o outro, a língua passa a ser vista como mutável, flexível e dinâmica.

No que tange ao trabalho com gêneros orais na escola, essa maneira de ver, desloca um estudo centrado apenas no dizer individual (subjetivo) de cada sujeito ou apenas na delimitação temática desse dizer -, e traz uma nova concepção em que este indivíduo precisa ser colocado em relação à responsabilidade do dito dentro do contexto sócio-histórico em que está inserido, consideradas aí todas as condições de produção/recepção e circulação do discurso.

A partir desse contexto de oposição às teorias linguísticas formalistas e de uma proposição sociológica de linguagem, podemos entender a concepção de enunciado concreto, também central nos textos do círculo.Para Bakhtin (195253/2016, p. 28), o enunciado é a "real unidade da comunicação discursiva", ou seja, é a realidade material da linguagem, constituída, por um lado, de uma parte verbal a língua - e, por outro, de uma parte extraverbal, a situação comunicativa que o envolve, incluídos aí não apenas o contexto mais imediato da interação, mas também a cadeia histórica e social mais ampla de que este enunciado faz parte.

A concepção de enunciado proposta pelo autor aponta na direção de que só é possível compreendê-lo dentro de uma situação concreta da interação verbal e, por isso mesmo, ele sempre estará voltado para o outro, um interlocutor, quer este esteja fisicamente presente, quer seja apenas pressuposto no momento do dito. A constituição do enunciado é, portanto, dialógica, visto que ele não pode existir fora de uma orientação social.

Neste sentido,Volóchinov procura diferenciar o enunciado concreto da sentença, frase e oração. Estas, como unidades linguísticas abstratas, não vinculadas à realidade, integram um sistema fechado, monológico e, portanto, não podem prestar à significação. Por isso mesmo, alertam: "Enquanto o enunciado como um todo permanecer terra incógnita para o linguista, não se pode falar de uma 
compreensão real, concreta e não escolástica das formas sintáticas." (VOLÓCHINOV, 1929/2017, p. 242)

No nosso entendimento, as questões da oralidade vão no mesmo caminho: enquanto essa oportunização de fala restringir-se apenas ao reconhecimento de estruturas - como a forma composicional dos gêneros ou as tipologias textuais que neles podem ser observadas - estaremos ainda fazendo um ensino abstrato do oral.

Em Palavra na vida e palavra na poesia, Volóchinov (1926/2013) já mostrava a importância de não se observar apenas os fatores linguísticos para a compreensão do enunciado, uma vez que se perde muito da significação quando não se considera a situação extraverbal implicada no verbal.O autor mostra nesse texto que o enunciado observado apenas sob o ponto de vista linguístico não consegue evidenciar toda a significação que nele pode haver. Para comprovar sua tese, apresenta um enunciado ("bem") e o analisa por dois ângulos: o linguístico (que não se pode compreender de fato) e o que considera também o contexto extraverbal (que realmente permite a compreensão do que é dito).

Duas pessoas se encontram em uma casa. Estão caladas. Uma delas diz: "Bem". O outro não responde nada.

Para nós outros, que não nos encontramos na casa na situação da conversação, todo esse "discurso" é absolutamente incompreensível. A enunciação "Bem", tomada isoladamente, é vazia e absolutamente carece de sentido. Não obstante, essa singular conversação entre os dois, que consta de uma só palavra expressivamente entonada, é plena de sentido, de importância e está perfeitamente concluída.

$[\ldots]$

Que nos falta? Nos falta, justamente, aquele contexto extraverbal no qual a palavra "Bem" apresenta um sentido para aquele que a ouve.

(VOLÓCHINOV, 1926/2013, p. 78)

A constituição desse contexto extraverbal, que integra o próprio enunciado, é marcada por três aspectos, segundo o autor: (1) o lugar físico em que estão os interlocutores; (2) o conhecimento comum da situação em que o enunciado é produzido; e, por fim, (3) o valor atribuído pelos dois à situação.

Nessa perspectiva, o enunciado é entendido na relação direta com a situação em que se deu o processo interativo. Em outras palavras, verbal e não-verbal estão 
intrinsicamente ligados no todo do enunciado e compreender o que está nele subentendido é fundamental para gerar sua significação integral.

Sobre o exemplo apresentado, o autor esclarece:

No momento da conversação, ambos os interlocutores olharam pela janela e viram que começava a nevar [aspecto 1]; os dois sabem que é mês de maio e que faz muito tempo que devia ter iniciado a primavera [aspecto 2]; finalmente, aos dois o inverno tão prolongado é um mal; ambos esperam a primavera e a queda da neve tão fora de época entristece os dois [aspecto 3].

(VOLÓCHINOV, 1926/2013, p. 78)

Esta realidade é fundamental, no nosso ponto de vista, para os estudos sobre a oralidade com enfoque bakhtiniano. Se a proposta didática do LDP, para o ensino do oral, propõe apenas uma orientação temática para guiar o aluno sobre o que dizer, ou apresenta instruções ligadas à situação mais imediata da produção do discurso, decerto estará pecando ao não levar o aluno a perceber que esse dito, por estar situado na vida, dela não pode ser separado, daí a necessidade de se compreender também os valores implicados na situação comunicativa.

Mais que palavras sobre determinado assunto, o enunciado produzido possui uma valoração e a forma desse dizer carregado de valor axiológico - a entonação deve ser considerada para se atingir a finalidade comunicativa, tendo em vista os interlocutores envolvidos e a situação mais ampla que envolve o enunciado. Buscaremos mostrar, em nossa análise do corpus, se isto acontece e, em caso afirmativo, como é concretizado na proposta didática.

Voltando à questão proposta no início desse tópico, é preciso ter claro que a linguagem, no interior de um ato de fala, assume um outro papel que foge tanto de uma visão centrada apenas no linguístico, como de uma concepção individual, dependente exclusivamente do enunciador. Considerada como um enunciado concreto, esse dizer só pode ser compreendido no interior de uma comunicação social efetiva e, portanto, não pode deixar de considerar seus interlocutores (e as relações hierárquicas entre eles), os embates histórico-sociais que dialogam com 
otexto, constituindo-o, e as relações ligadas à situação comunicativa, seja mais imediata, seja a ligada à grande temporalidade ${ }^{32}$.

Compreendida a noção de enunciado, é importante refletir sobre quem é esse sujeito que faz uso da linguagem e mostra sua voz em uma dada situação de interação verbal.

\subsection{Constituição do sujeito no círculo bakhtiniano}

Entendendo o momento de realização da fala não mais como resultado exclusivo da consciência individual de um falante e da situação imediata que envolve o dito,o papel do sujeito que enuncia também se modifica, visto que ele passa a ser compreendido no interior das relações sociais de que participa. Assim, ele constituise como um ser social, histórico e ideológico, que se constrói na interação e na relação com o universo da cultura.

Aquilo que é normalmente chamado de "individualidade criativa" expressa a linha fundamental, firme e constante daorientação social de um homem.

O centro organizador de qualquer enunciado, de qualquer expressão, não está no interior, mas no exterior: no meio social que circunda o indivíduo.

Ao contrário do que diz a doutrina do objetivismo abstrato, o enunciado singular ("parole")de modo algum éum fato individual (...).

A estrutura do enunciado, bem como da própria vivência expressa, é uma estrutura social.

(VOLÓCHINOV, 1929/2017. p. 215-217. Ênfase nossa)

\footnotetext{
${ }^{32}$ A grande temporalidade, como compreende os estudos bakhtinianos, está diretamente ligada à "complexa unidade da cultura humana", situada, portanto, na história, ou melhor, no diálogo entre história e cultura. A discussão proposta por Bakhtin ao falar no "grande tempo" reforça a importância de não se observar apenas o momento imediato (e sua relação com o passado e futuro próximos) em que um enunciado apresenta seu acabamento, mas, pelo contrário, é fundamental considerar que "cada imagem precisa ser entendida e avaliada no nível do grande tempo", pois é na relação entre a atualidade (pequeno tempo) e o grande diálogo infinito e inacabável da história (grande tempo) que ocorre a "renovação interminável dos sentidos em todos os contextos". (BAKHTIN, 1979/2011c, p. 406, 407, 409, respectivamente)
} 
A ênfase dada à constituição social do sujeito evidencia que este, no diálogo constante com a sociedade que o cerca, assimila as diversas vozes que nela circulam. Assim, seu interior não é formado por apenas uma voz, mas inúmeras vozes sociais que, no embate e no encontro, vão se reelaborando, evidenciando que o próprio indivíduo é dialógico.

Essas vozes são interiorizadas ora como voz de autoridade - verdade incontestável, sobre a qual não se pode argumentar - ora como uma palavra internamente persuasiva - esta sim mais flexível e aberta à mudança. É na relação dialógica dessas duas formas de vozes que está pautada a consciência ideológica do sujeito. Uma consciência evidentemente heterogênea, visto que este está mergulhado em uma sociedade em cujos valores não são unos.

Dada a dinâmica dialógica que envolve nosso mundo interior, os enunciados produzidos por esse sujeito vão aparecer como resposta a essas vozes sociais interiorizadas. Por esse motivo é que Volóchinov (1929/2017) assume a tese de que todo enunciado é de certa forma um discurso citado, seja pelo fato de termos a consciência da bivocalidade, conseguindo delimitar o discurso do outro - o que em geral é feito, no texto escrito, com o uso de aspas -, seja pela não percepção dessa alteridade, dada a já incorporação dessas vozes à sua consciência interior - o que resultaria no texto escrito, por exemplo, na não utilização de aspas.

A compreensão de um indivíduo cuja consciência interior está repleta de vozes sociais e cujos enunciados são entendidos como discurso citado poderia fazer crer na existência de um sujeito passivo, que simplesmente "recebe" do meio em que vive todo o conteúdo ideológico do grupo social. O Círculo distancia-se desse pensamento e mostra que o sujeito assume uma postura ativa, tanto no papel de ouvinte:

(...) o ouvinte, ao perceber e compreender o significado (linguístico) do discurso, ocupa simultaneamente em relação a ele uma ativa posição responsiva: concorda, ou discorda dele (total ou parcialmente), completa-o, aplica-o, prepara-se para usá-lo, etc.; essa posição responsiva do ouvinte se forma ao longo de todo o processo de audição e compreensão desde o seu início, às vezes literalmente a partir da primeira palavra do falante. Toda compreensão da fala viva, do enunciado vivo é de natureza ativamente responsiva (...). 
quanto no de falante:

O próprio falante está determinado precisamente a essa compreensão ativamente responsiva: ele não espera uma compreensão passiva, por assim dizer, que apenas duble o seu pensamento em voz alheia, mas uma resposta, uma concordância, uma participação, uma objeção, uma execução, etc.

(BAKHTIN, 1952-53/2016, p. 25-26)

Neste processo, os papeis de falante e ouvinte estão intrinsicamente ligados visto que "todo falante é por si mesmo um respondente" e no processo de compreensão "o ouvinte se torna falante". (BAKHTIN, 1952-53/2016, p. 26 e 25, respectivamente)

O sujeito evidencia, com isso, sua não passividade, o seu não assujeitamento, uma vez que, ao apropriar-se do discurso alheio, ele o analisa, reelabora, rejeita, enfim, faz escolhas e, com isso, também contribui, a partir de sua interação no mundo, com o processo social da linguagem.

Realiza-se, portanto, um caminho de mão dupla: tanto a atividade social é relevante para a formação da consciência individual do sujeito, quanto este, contribui para reelaborar o discurso social.

No interior da teoria bakhtiniana, o sujeito será ao mesmo tempo social e singular, pois que responde de maneira específica e única às diversas vozes que circulam na vida, constituindo-se ideologicamente em relação a elas.

Faraco (2009, p. 86-87) sintetiza essa questão mostrando que "o sujeito é social de ponta a ponta", pois tanto a origem quanto a lógica da consciência são exteriores a ela, mas também "singular de ponta a ponta", visto que cada consciência é um reflexo de condições específicas e singulares, assim como cada Ser é um evento único.

A responsividade que caracteriza esse sujeito, sempre em constante diálogo no interior de uma dada situação concreta, portanto sempre respondendo a algo, é apenas um dos aspectos a serem considerados quando compreendemos a constituição de sujeito na teoria bakhtiniana. Outraimportante questão a ser observada é a responsabilidade desse ser que enuncia, ou seja, o seu comprometimento frente ao dito. 
Para unir esses dois termos, Sobral propõem o uso da palavra "responsibilidade", um neologismo formado a partir dos conceitos do que é "responsível" (que admite resposta) e "responsável" (que assume responsabilidade). Assim, é possível observar que "um responder responsável (...) envolve necessariamente um compromisso ético do agente."(SOBRAL, 2005, p. 20)

Nessa perspectiva, o sujeito é um ser ético, responsável pelo seu dizer e situado em uma dada realidade concreta, com a qual está em constante diálogo, respondendo ao todo e, ainda, integrando de forma participativa essa realidade.

Essa concepção de sujeito vem ao encontro do que entendemos como central no trabalho com a oralidade ao final do ensino médio. Mais que apenas ensinar as formas da língua - ou do gênero discursivo - de que os alunos poderão fazer uso para se expressar em uma dada situação. É fundamental também formar cidadãos que, assumindo uma consciência crítica,sejam capazes de apropriarem-se de diversas vozes para, então, interferiremde forma responsável na realidade da qual fazem parte.

\subsection{Gêneros do discurso e esfera da comunicação social}

Como se organiza esse dizer? Como o enunciado se constitui para garantir a apropriação de uma formação crítica pelo sujeito?

Bakhtin e o Círculo vão refletir sobre isso e mostrar que o falante, para produzir seu discurso, molda seu dizer a formas linguísticas mais ou menos comuns, com a qual poderá ser compreendido por seu ouvinte no interior de uma dada situação. A essas formas típicas que apresentam uma estabilidade relativa de construção do todo do enunciado é que nomeiam por "gêneros do discurso".

O conceito aparece pela primeira vez em $O$ método formal nos estudos literários (MEDVIÉDEV, 1928/2012) com o intuito de apontar uma problemática proposta pelos formalistas, que consideravam o gênero como uma forma préestabelecida, mecanicamente articulado e desvinculado do todo da obra. A crítica recaía especialmente sobre uma visão analítica que considerava apenas a estrutura do texto, desvinculando-a da realidade e do domínio temático que a envolve. 
Medviédev procura demonstrar que esta maneira de raciocínio é estreita, visto que a forma, sozinha, não dá conta de evidenciar a complexidade maior do gênero, uma vez que este está orientado tanto para a vida - do qual não pode se desprender - como para os interlocutores e a situação mais imediata, situados no interior de uma dada esfera ideológica.

Para o autor (MEDVIÉDEV, 1928/2012, p. 201), "o gênero lança uma luz sobre a realidade, enquanto a realidade ilumina o gênero". São, portanto, interdependentes, visto que um está em constante ligação com o outro.

Assim, mais que apenas observar uma estrutura isolada de dizer, o autor vai apontar que embora a forma composicional faça parte do todo do gênero, é fundamental também considerar seu acabamento temático e este está diretamente vinculado ao todo da situação discursiva e, portanto, só pode ser apreendido no movimento da vida.

Evidenciando a dinamicidade do gênero, Bakhtin, em 1929, também tratando do discurso literário, aponta, em Problemas da poética de Dostoievski, que:

O gênerosempre é e não é o mesmo, sempre é novo e velho ao mesmo tempo. O gênero renasce e se renova em cada nova etapa do desenvolvimento da literatura e em cada obra individual de dado gênero. Nisto consiste a vida do gênero. (...). O gênero vive no presente, mas sempre recorda o seu passado, o seu começo. É o representante da memória criativa no processo de desenvolvimento literário. É precisamente por isto que tem a capacidade de assegurar a unidade e a continuidade desse desenvolvimento.

(BAKHTIN, 1929/2008, p. 121. Ênfase do autor)

O autor reforça, então, a ideia de que não se pode compreender um gênero apenas considerando sua estrutura como algo estático, nem olhar somente para o momento presente de sua produção. Sua compreensão está na relação entre o ontem e o hoje, entre o social e o individual, e é esta característica que o constitui, não como algo fixo, mas como algo flexível, aberto a mudanças.

Em Marxismo e filosofia da linguagem (1929/2017), Volóchinovvai sinalizar para a questão do gênero, mostrando a relação deste com a vida, com o interlocutor e com toda a situação extraverbal que envolve o dito: 
O gênero cotidiano é uma parte do ambiente social: da festa, do lazer, da conversa na sala de visitas, na oficina etc. Ele entra em contato com esse ambiente, que o limita e define em todos os seus aspectos interiores. ${ }^{33}$

(VOLÓCHINOV, 1929/2017, p. 222)

O autor também reforça a importância dos gêneros para orientar a comunicação social, visto que eles refletem "formas" mais ou menos estáveis que foram internalizadas durante o processo de formação sócio-histórica, facilitando a interação entre os indivíduos.

Cada situação cotidiana recorrente possui uma determinada organização do auditório e portanto um determinado lugar, o gênero cotidiano se insere em uma determinada via da comunicação social, sendo um reflexo ideológico do seu tipo, estrutura, objetivo e composição social.

(VOLÓCHINOV, 1929/2017, p. 222)

Embora as sementes desse conceito apareçam em obras anteriores, uma discussão sobre essa problemática é desenvolvida em um longo ensaio intitulado Os gêneros do discurso, escrito em 1952/1953, em que se localiza uma definição do termobastante conhecida: "cada enunciado particular é individual, mas cada campo de utilização da língua elabora seus tipos relativamente estáveis de enunciado, os quais denominamosgêneros do discurso." (BAKHTIN, 1952-53/2016, p. 12)

A partir dessa definição é possível organizar o seguinte esquema:

\footnotetext{
${ }^{33}$ Vemos nesta passagem uma marca que evidencia a relação entre o gênero e a esfera, que será mais tarde desenvolvido no ensaio Os gêneros do discurso, de 1952-53.
} 
Figura 3 - Relação entre enunciado e gênero do discurso

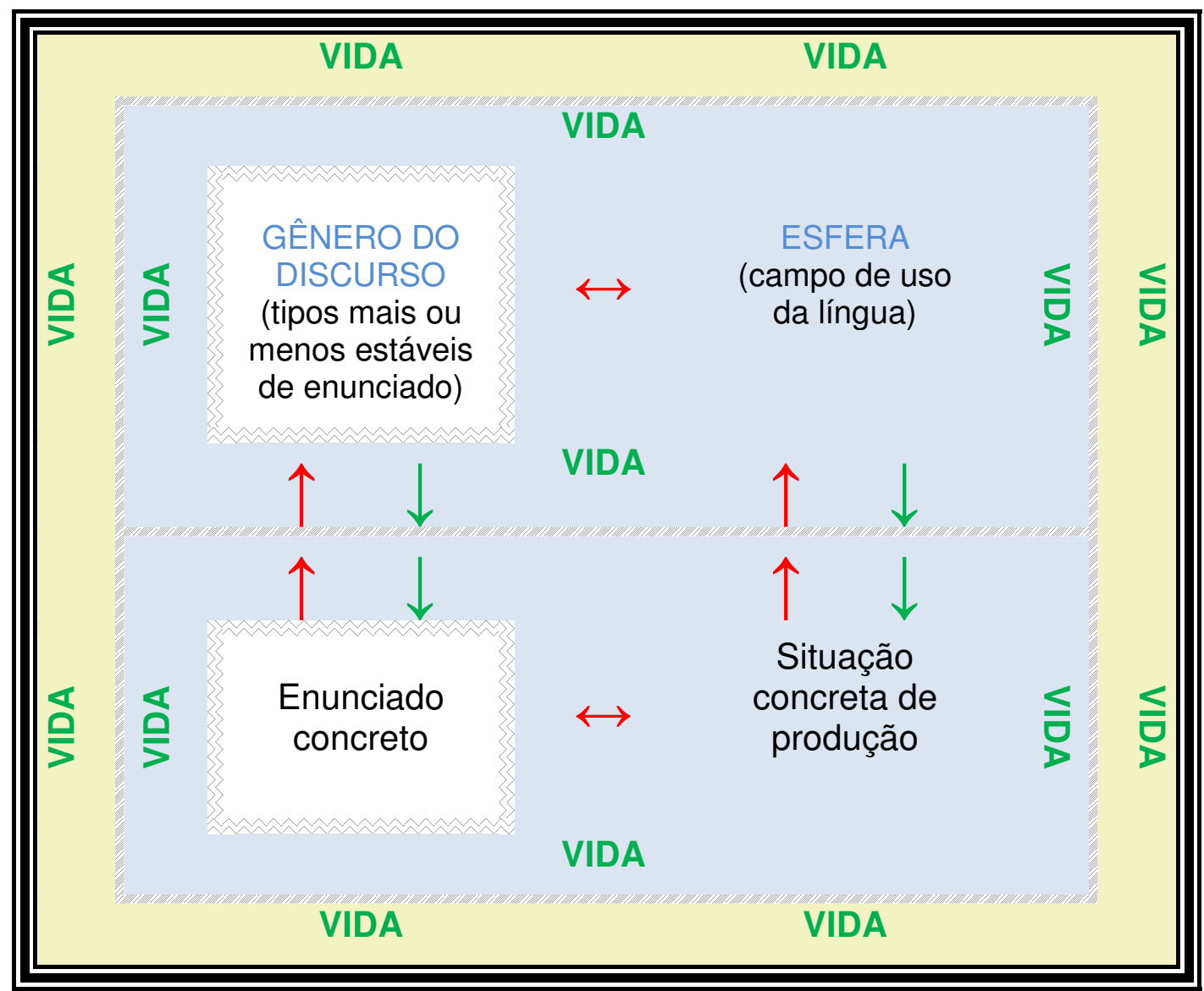

Fonte: Elaboração nossa.

$\mathrm{Na}$ vida, produzimos enunciados diversos que atendem aos nossos propósitos comunicativos mais imediatos. Nesta instância, tanto o enunciado atende à situação concreta de produção (relação entre interlocutores e finalidade do dizer, por exemplo), como essa situação influencia as escolhas do sujeito ao produzir enunciados. É nesse sentido que Bakhtin afirma que estes sãoirrepetíveis, visto que cada situação é única e gera, portanto, uma "realidade material da linguagem" - um enunciado - particular e individual.

Ao mesmo tempo, o autor reforça a tese já presente nos estudos anteriores, conforme vimos demonstrando até aqui, de que esse dizer está carregado do social, visto que atende às necessidades das esferas de comunicação, ou seja, aos campos de uso da língua mais amplos, relacionando-se às ideologias e forças de poder presentes nelas. Vemos aí, portanto, a relação entre a situação concreta de produção e as esferas mais amplas de comunicação social, cada uma exercendo 
influência sobre a outra: a primeira reflete e refrata as características da esfera e esta se constitui também a partir das diversas situações reais de interação.

No que tange à relação entre enunciado concreto e gêneros do discurso, Bakhtin vai definir o caráter genérico do enunciado evidenciando que este, se observado no interior de uma dada esfera de comunicação, pode apresentar características mais ou menos comuns, o que facilitaria a organização social da linguagem. Reforça, no entanto, que apesar de serem "tipos de enunciado", não devem ser entendidos como esquemas ou formas fixas, daí o uso do termo "relativamente", para mostrar que esta estabilidade é flexível.

Essa maleabilidade do gênero só é compreensível no interior de uma dada esfera, ou seja, no campo de uso efetivo da língua. Em outras palavras, a esfera exerce influência na criação/transformação de um gênero e este, como enunciado típico, também responde aos interesses dessa esfera.

\begin{abstract}
A vontade discursiva do falante se realiza antes de tudo na escolha de certo gênero do discurso. Essa escolha é determinada pela especificidade de um dado campo da comunicação discursiva, por considerações semântico-objetais (temáticas), pela situação concreta da comunicação discursiva, pela composição pessoal dos seus participantes, etc. Em seguida, a intenção discursiva do falante, com toda a sua individualidade e subjetividade é aplicada e adaptada ao gênero escolhido, constitui-se e desenvolve-se em determinada forma de gênero.
\end{abstract}

(BAKHTIN, 1952-53/2016, p. 37-38. Ênfase do autor)

Essa afirmação reforça o que buscamos evidenciar em nosso esquema: a relação intrínseca entre os enunciados produzidos no interior de uma situação concreta de produção e os gêneros discursivos, integrantes de uma dada esfera social, que são utilizados pelos sujeitos para se comunicar na vida.

Segundo Bakhtin (1952-53/2016), atuam nos gêneros duas forças: de concentração e de dispersão. A primeira - força centrípeta - está relacionada à estabilidade que eles apresentam, observável, por exemplo, pelas manifestações semelhantes da língua em uma determinada situação. Ela tem papel importante na manutenção da compreensão entre os interlocutores e na própria economia da comunicação. A segunda - força centrífuga -atua na direção oposta e é a responsável pela flexibilidade do gênero, pois permite a este variar de acordo com o 
estilo do indivíduo, as mudanças sociais mais amplas e a própria influência ideológica da esfera em que circula.

A heterogeneidade dos gêneros do discurso poderia ser um problema para a compreensão de sua natureza. Por esse motivo, o autor vai afirmar que "é de especial importância atentar para a diferença essencial entre os gêneros discursivos primários (simples) e secundários (complexos)" (BAKHTIN, 1952-53/2016, p. 15). Os primeiros seriam aqueles que circulam na vida cotidiana e estariam mais ligados aos contextos de comunicação oral - embora não exclusivamente -, visto que se desenvolvem em circunstâncias mais espontâneas e imediatas de comunicação, como o diálogo familiar. Os segundos seriam os gêneros ligadosà vida da cultura e, ainda que não apenas escrito,estariam relacionados,em grande medida, a essa forma de comunicação.Servem de exemplo, o romance, pesquisas científicas, anúncio publicitário etc.

Esses conceitos, entendidos de forma estanques, poderiam fazer crer na existência de uma oposição radical entre eles, ou seja, o primário ou o secundário ser mais ou menos importante que o outro. Talvez por isso o autor vá mostrar que existe uma "relação mútua dos gêneros primários e secundários": estes incorporam aqueles e aqueles, ao serem incorporados, transformam-se. (BAKHTIN, 195253/2016, p. 16).

Outro cuidado necessário para compreensão desses dois conceitos é a associação do uso do discurso oral exclusivamente ao gênero primário e o do uso da língua escrita ao gênero secundário. Se fossem entendidos dessa forma, teríamos aí uma separação radical da noção de oralidade e escrita, conforme ocorreu na época da "grande divisa", vista no capítulo anterior.

Essa leitura da obra de Bakhtin não se justifica, porque o autor, ao tratar do gênero secundário, afirma que este pode ser "predominantemente o escrito" (BAKHTIN, 1952-53/2016, p. 15, grifo nosso) e, neste sentido, o uso do advérbio que antecede o substantivo nesta sentença indica a não exclusividade. Além disso, se os gêneros primários e secundários são interligados, então se pode concluir que há gêneros mais espontâneos realizados na modalidade escrita (como os bilhetes) e mais elaborados ligados à oralidade (como é o caso de uma palestra ou discurso político). 
O que parece diferenciá-los, portanto, não é o fato de os discursos serem orais ou escritos, mas a situação de realização desses enunciados: se mais próximos da vida cotidiana e mais distantes da cultural (primários) ou se o inverso (secundários).

Para fins práticos do ensino, considerando nosso particular interesse de reflexão nessa pesquisa, essas noções servem apenas de balizadores para levar os jovens a perceberem essas diferenças na produção do discurso. É fundamental levar o aluno a perceber que ao dizer algo não é necessário apenas dominar os recursos linguísticos, mas necessário perceber que, atendendo a diferentes propósitos, no interior de uma dada formação social, esses dizeres poderão ser transformados. Por este motivo, uma conversa familiar será diferente de uma entrevista de emprego, ainda que a cena enunciativa possa ter algo em comum (como a interação face a face dos interlocutores).

Questionamos apenas a associação da palavra "simples" aos gêneros primários, visto que, considerando que em todas as esferas atuam forças de poder e que nestas há também formações ideológicas sociais, um diálogo familiar pode ser, em determinadas situações, tão complexo quanto um gênero que circula nas demais esferas. Mais uma vez entendemos que mais que oposições ("simples x complexo", "oralidade x escrita"), o enfoque do ensino deve se dar por meio da compreensão das esferas de comunicação em que estes gêneros circulam, observandoo uso de uma dada linguagem em relação às forças que sobre elas atuam.

No que tange à composição do gênero, Bakhtin vai apontar que três elementos estão nele indissoluvelmente ligados: forma composicional, conteúdo temático e estilo.

O emprego da língua efetua-se em forma de enunciados (orais e escritos) concretos e únicos, proferidos pelos integrantes desse ou daquele campo da atividade humana. Esses enunciados refletem as condições específicas e as finalidades de cada referido campo não só por seu conteúdo (temático) e pelo estilo de linguagem, ou seja, pela seleção dos recursos lexicais, fraseológicos e gramaticais da língua mas, acima de tudo, por sua construção composicional.

(BAKHTIN, 1952-53/2016, p. 11-12)

A forma composicional relaciona-se à construção estrutural do texto, isto é, sua organização; está, portanto, ligada ao plano da expressão. É claro, no entanto, 
que quem se expressa precisa fazer uso de recursos da língua - o estilo - que, diferentemente do que situava a Estilística tradicional, para Bakhtin não é resultado exclusivo de uma escolha meramente individual, mas também de um reflexo do social, em que este indivíduo está imerso.E como quem diz, diz algo, o tema seria o objeto do discurso, isto é, aquilo de que se fala em uma determinada situação comunicativa. Reforça-se, no entanto, que este dizer está carregado de valoração, então o estudo do "tema" bakhtiniano envolve não só o conteúdo do dito, mas também a valoração desse dizer.

Nenhum desses três elementos atua sozinho, o que evidencia o constante diálogo sempre presente nos estudos do Círculo. As escolhas linguísticas realizadas pelo locutor, por exemplo, nunca são aleatórias, uma vez que são feitas considerando o horizonte extraverbal da situação de comunicação. O tema - que abarca todo um centro de valores de uma determinada época - direciona essas escolhas, bem como a própria opção por usar esta ou aquela estrutura de organização textual.

É importante destacar, ainda, que embora Bakhtin evidencie a composição do gênero, elencando seus três elementos, o autor não deixa de observar que estes estão "ligados noconjunto do enunciado e são igualmente determinados pela especificidade de um determinado campo da comunicação." (BAKHTIN, 195253/2016, p. 12, ênfase do autor).

Entendemos, assim, que conhecer a forma de organização do gênero é importante, mas apenas se este for considerado no interior da esfera de que ele participa, ocasião em que de fato ele ganha seu acabamento. Nada mais distante do pensamento bakhtiniano que propostas que visem apenas o reconhecimento de estruturas dos textos ou de suas formas de linguagem características, sem relacionar essas escolhas com o campo efetivo de sua produção, recepção e circulação.

Um trabalho que evidencia o que viemos demonstrando até aqui é o apresentado por Campos (2011), ao analisar as crônicas publicadas na Revista do Brasil, periódico que circulou de 1918 a 1925, na cidade de São Paulo. Ao fazer a análise das crônicas, a autora não focou seu estudo em uma descrição da organização estrutural do texto, mas, primeiro situou o contexto cultural mais amplo 
que envolvia a publicação do periódico, estimulando uma reflexão sobre a esfera de circulação da revista e trazendo à tona, com isso, as diversas forças de poder constante à época; depois reconstruiu a história do próprio gênero, mostrando com isso os diálogos possíveis para a construção de sentidos de seu corpus; e, por fim, na análise das dezessete crônicas selecionadas, optou pelo estudo da inserção do discurso do outro, da paráfrase, da réplica, dentre outros - recursos ligados ao estilo, às marcas linguísticas usadas pelo enunciador - para chegar ao tema, isto é, ao sentido do todo do enunciado, carregado de valores e posicionamentos e da parte extraverbal que constitui um texto em seu acabamento.Por esse estudo, então, mais que apenas conhecer a organização composicional de crônicas de uma época de nossa história literária, é possível compreender a pluralidade de perspectivas culturais que constituíram a identidade do Brasil no período.

Tratemos agora da inserção do conceito de gêneros do discurso na esfera escolar.

O ensaio Os gêneros do discurso, escrito em 1952-53 e publicado na Rússia em 1979, embora integre uma coletânea ${ }^{34}$ de textos inacabados do autor, serviu de referência para dar sustentação ao discurso pedagógico que passou a defender o ensino por meio dos gêneros discursivos.

A apropriação deste conceito, no entanto, ingressou na escola com uma lacuna significativa, uma vez que, mais uma vez - como ocorreu com os estudos formais da literatura -, o foco deste estudo recaiu sobre um ensino mecânico de sua forma composicional ou dos componentes linguísticos que davam suporte à sua produção, deixando de lado a questão da valoração do discurso e a relação deste com a vida real.

A esse respeito, Faraco evidencia:

Poderíamos nos perguntar, neste ponto, sobre o que diferencia a teoria dos gêneros do Círculo de Bakhtin das teorias tradicionais, inclusive para entendermos criticamente a apropriação pedagógicaepidêmica de seu conceitual nos últimos anos.

Uma característica daquela teoria é que, diferentemente de outras, ela não pensa os gêneros em si (muito embora seja esta a perspectiva dominante na apropriação pedagógica do conceito), isto é, como conjunto de artefatos que partilham determinadas propriedades formais.

\footnotetext{
${ }^{34}$ Referimo-nos à obra Estética da criação verbal (BAKHTIN, 1979/2011a).
} 
Os gêneros não são enfocados apenas pelo viés estático do produto (das formas), mas principalmente pelo viés dinâmico da produção. Isso significa dizer que a teoria do Círculo assevera axiomaticamente uma estreita correlação entre os tipos de enunciados (gêneros) e suas funções na interação socioverbal; entre os tipos e o que fazemos com eles no interior de uma determinada atividade social."

(FARACO, 2009, p. 125-126. Ênfase nossa.)

Observe que o uso da palavra "epidêmica", na citação acima, remete-nos para uma visão de "doença em massa", algo ruim, negativo. Será então que a noção de gênero seria uma problemática? Na visão do autor (FARACO, 2009), compartilhada por nós, o problema não está no conceito em si, mas no não entendimento de sua completude. Se na escola, trabalharmos apenas com "formas de texto", sem evidenciar sua dinâmica no uso prático e sem apontar sua mobilidade, não estaremos fazendo exatamente o que fizeram os estudiosos da gramática tradicional, focando em estruturas como algo já pronto e fixo?

Nada mais avesso à proposta bakhtiniana que um estudo que se comprometa apenas com o reconhecimento de formas ou de aplicação de estruturas linguísticas dadas, sem reflexão, sem compreensão de seu uso na vida.

No que tange ao estudo da oralidade, essa questão é igualmente fundamental, visto que, sob a perspectiva desta teoria, não basta apenas estudar a estrutura de um debate, seminário ou exposição oral, por exemplo; é preciso mostrar como esse dizer, situado no interior de uma atividade humana concreta, atende às expectativas de uma dada esfera social, responde a um tempo/história concretos e direciona-se tanto para os participantes envolvidos, quanto para a formação ideológica desta sociedade. Além disso, é importante levar os alunos a perceberem como a fala (assim como a escrita) nunca é neutra, ou seja, tem uma valoração que evidencia um posicionamento do indivíduo no social. Faz-se, portanto, necessário incluir na reflexão pedagógica a relação entre os gêneros produzidos e os embates socio-ideológicos desse dizer.

\subsection{Entonação expressiva e valoração da linguagem}

A relevância da valoração do enunciado encontra-se bastante presente em diversos momentos na obra bakhtiniana. 
Em Marxismo e Filosofia da Linguagem, o autor afirma que "a palavra está sempre repleta de conteúdo e de significação ideológica ou cotidiana"(VOLÓCHINOV, 1929/2017, p. 181).Ele se afasta, uma vez mais, de um estudo de língua focado apenas no sistema e mostra que a consideração do contexto ideológico é tão necessária quanto a atenção que normalmente se dá ao momento em que se produz o discurso. Dessa forma, segundo o autor, "nunca pronunciamos ou ouvimos palavras, mas ouvimos uma verdade ou uma mentira, algo bom ou mal (sic), relevante ou irrelevante, agradável ou desagradável (...)". (VOLÓCHINOV, 1929/2017, p. 181) Em suma, são palavras carregadas de valoração.

No ensaio A construção da enunciação, Volóchinov(1930/2013b) vai mostrar que o valor da palavra pode ser observado no enunciado concreto a partir da entonação, a qual é definida como "a expressão sonora da valoração social" e "a expressão da valoração da situação e do auditório" (VOLÓCHINOV, 1930/2013b, p. 175 e 177, respectivamente).Com isso, vai evidenciar como essa entonação sofre a influência tanto do auditório - da valoração que o falante faz dele - quanto da orientação social do enunciado e, em menor medida, do próprio tema da conversação.

O esquema a seguir, elaborado por nós a partir dos estudos realizados por Volóchinov (1930/2013b, p. 180-181), evidencia ainter-relação desses elementos. 
Figura 4 - Relação entre situação, auditório e entonação

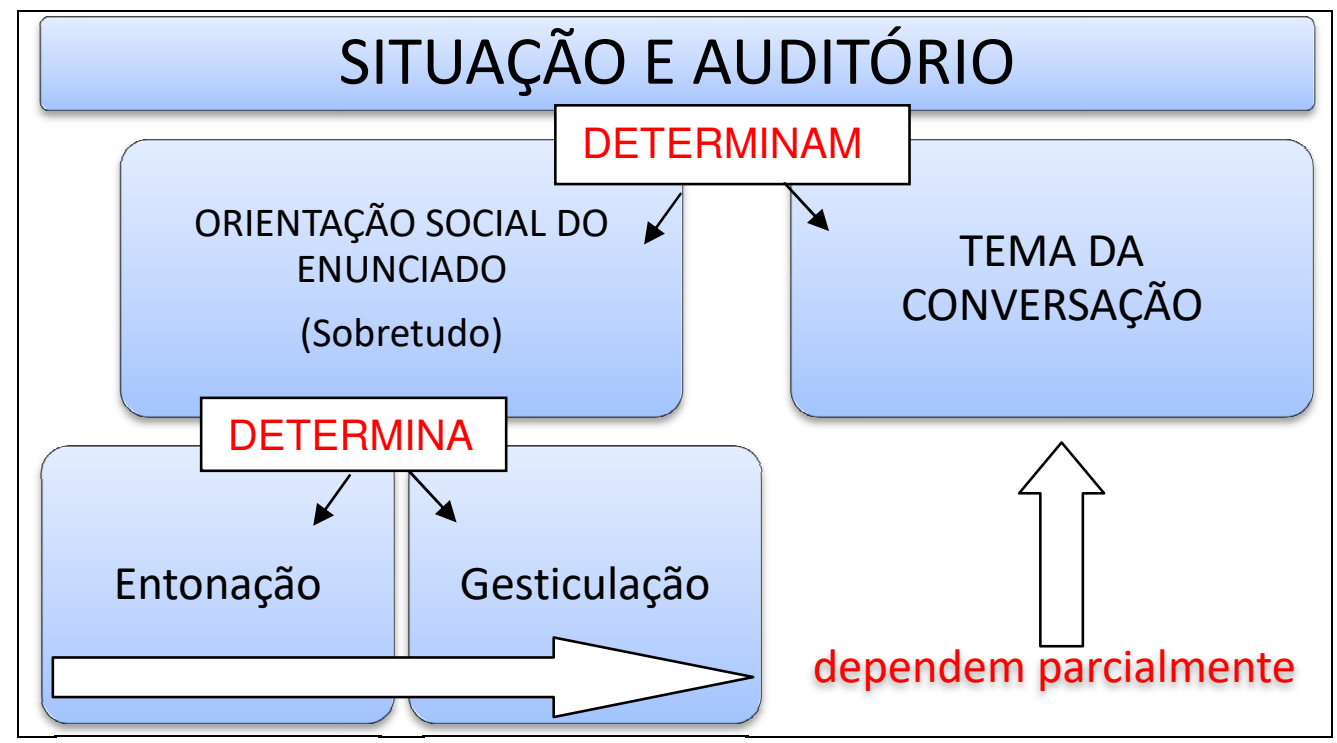

Fonte: VOLÓCHINOV,1930/2013b.

A defesa do conceito de entonação já estava presente na obra de 1926, $A$ palavra na vida e a palavra na poesia, em que Volóchinov, aponta a relação intrínseca entre a obra e a vida e vai mostrar que a seleção do material verbal e da forma do todo do enunciado não se dá sem um julgamento de valor.

Acima de tudo, as valorações determinam a seleção das palavras pelo autor e a percepção desta seleção (co-eleição) pelo ouvinte. Porque o poeta não escolhe suas palavras de um dicionário, mas do contexto da vida no qual as palavras se sedimentam e se impregnam de valorações. Deste modo, escolhe as valorações relacionadas com as palavras e, além disso, desde o ponto de vista dos portadores encarnados desta valorações.

(VOLÓCHINOV, 1926/2013, p. 88)

A valoração do enunciado, desta forma, não é observável apenas no conteúdo do que é dito, mas é reconhecível pelas escolhas linguísticas empreendidas pelo enunciador, bem como pela forma que dá ao seu discurso. Em outras palavras, pode-se afirmar que tanto o estilo, quanto a forma composicional evidenciam esse juízo de valor, esse posicionamento do sujeito em relação ao dito. 
Volóchinovdestaca, ainda, que essa visão avaliativa realiza-se na entonação, ou seja, no "tom" do discurso, e pode ser observada também pelos gestos, pois é "entonando e gesticulando [que] o homem ocupa uma posição social ativa com respeito aos valores determinados, determinadas pelas mesmas condições de sua existência social." (VOLÓCHINOV, 1926/2013, p. 85). Com isso o autor coloca tanto a entonação quanto os gestos na fronteira entre o verbal e o extraverbal e, mais uma vez, evidencia o aspecto social imbricado em sua produção.

Segundo o autor, há duas direções possíveis para a qual a entonação está orientada: uma voltada para o interlocutor e a outra para o próprio objeto do discurso. Assim, evidenciam-se três participantes na produção do enunciado: o falante (autor), o ouvinte (leitor) e o tópico da fala (o que ou o quem da fala: o herói).

Esta relação entre os três elementos deixa claro que qualquer trabalho que se deseja fazer em relação ao estudo de gêneros discursivos (orais ou escritos) deve levar o produtor do texto a perceber que seu enunciado é orientado para um interlocutor dentro de uma realidade social concreta e que ele, ao assumir o dito, posiciona-se frente a ele, responsabilizando-se por sua palavra.

A responsabilidade deste dizer está claramente marcada emPara uma filosofia do ato responsável, ocasião em que Bakhtin defendea unicidade do ser e do evento, afastando-se das generalizações que não consideram o ato singular e das teorizações que afastam-se da vida: "cada valor que apresente validade geral se torna realmente válido somente em um contexto singular" (BAKHTIN, 1920-24/2010, p. 90)

Por ser único, este ser torna-se responsável, uma vez que, no interior de um ato concreto, "tudo o que pode ser feito por mim não poderá nunca ser feito por ninguém mais, nunca". É nessa direção que Bakhtin assevera o "não-álibi no existir", ou seja, a partir do momento em que o sujeito reconhece sua singularidade e compreende sua participação concretana unicidade do evento singular, já se responsabiliza e assume um posicionamento. (BAKHTIN, 1920-24/2010, p. 96)

A entonação, segundo a visão defendida pelo autor, ocupa um papel fundamental, visto que "uma palavra realmente pronunciada não pode evitar de ser entoada, a entonação é inerente ao fato mesmo de ser pronunciada"(BAKHTIN, 1920-24/2010, p. 85). Esse conceito é então compreendido, mais uma vez, como 
uma tomada de posição que o sujeito assume para si, evidenciando sua atitude avaliativa em relação ao outro (o objeto do discurso e seu interlocutor). Ou seja, a entonação é um momento imprescindível do ato e, desta forma, não pode ser apartada do enunciado concreto.

Considerando nosso interesse em refletir sobre aspráticas orais no LDP de ensino médio, em especial com o gênero debate, entendemos que o conceito de entonação será fundamental para compreender se de fato o aluno é levado a refletir sobre a valoração do seu discurso e, com isso, assumir sua posição autoral diante de seu dizer. Assim, faz-se necessário levá-lo a perceber que o dito é mais que uma palavra, é um agir sobre a realidade, é uma tomada de posição observada não só pela escolha do dito, mas, inclusive, do não-dito.

É preciso reforçar mais uma vez que essa valoração a que o Círculo faz menção não pode ser entendida como algo subjetivo, resultado de uma apreciação meramente pessoal. Como o próprio sujeito é social, o tom avaliativo de seu discurso é constituído na relação entre a posição socialmente determinada pela realidade e o ponto de vista que o sujeito tem sobre ela. Nessa direção é que Volóchinov questiona: “palavras como 'classe', 'revolução', 'comunismo' (...) não serão acompanhadas de avaliação diferente em enunciações de um lavrador e de um burguês (...)?" (VOLÓCHINOV, 1930/2013c, p. 199).

No processo de ensino de gêneros orais na escola, no que tange à reflexão sobre a entonação, acreditamos que seja necessário levar o aluno a refletir sobre as diferenças de valoração, mesmo em enunciados potencialmente "iguais". $E$, ampliando um pouco mais essa visão, é preciso ajudá-los a perceber, assim como exposto por Sobral (2005, p. 22), que “(...) o valor é sempre um valor para sujeitos, entre sujeitos, numa dada situação".

\subsection{Livro didático como acontecimento}

A discussão teórica apresentada nos permite defender a tese de que o livro didático pode ser entendido como um acontecimento.

Essa terminologia - "acontecimento" - está presente na tradução espanhola do texto inacabado de Bakhtin, intitulado "Hacia una filosofíadelacto ético. De 
losborradores y otros escritos.". A tradução para o português ${ }^{35}$ traz, em seu lugar, o termo "existir-evento", como se pode observar na comparação das citações a seguir:

Todas lasactividades mencionadas establecen una escisión de principio entre elcontenido-sentido de unacto (actividad) determinado y larealidad histórica de suexistencia (como vivencia experimentada enlarealidad por una sola vez), cuyaconsecuencia es que elactopierdesucapacidad de ser valorado, lomismo que se pierdelaunidad entre sudevenirviviente y laautodeterminación. Sóloelacto em sutotalidad es real y participa enelacontecimiento unitário de ser, sólo este acto es vivo y es plena e inextricablemente, es decir, está em el processo de generación, deviene, se realiza, siendo partícipe vivientedelacontecimiento de ser: forma parte de launidad única del processo de ser, pero esta participación no penetra em su aspecto de contenido semântico, aspecto que pretende autodeterminarse plena y definitivamente dentro de launidad de una u outra área del sentido - de la ciência, del arte, de la historia -, mientras que estas áreas objetivas em su sentido própio, más allá de lacto que las integra, no sonreales, segúnhemos demostrado.

(BAJTIN, 1997, p. 7-8, grifo nosso).

Todas essas atividades ${ }^{36}$ estabelecem uma separação de princípio entre o conteúdo-sentido de um determinado ato-atividade e a realidade histórica de seu existir, sua vivência realmente irrepetível; como consequência, este ato perde precisamente o seu valor, a sua unidade de vivo vir a ser e autodeterminação. Somente na sua totalidade tal ato é verdadeiramente real, participa do existir-evento; só assim é vivo, pleno e irredutivelmente, existe, vem a ser, se realiza. É um componente real, vivo, do existir-evento: é incorporado na unidade singular do existir que se vai realizando, mas esta incorporação não penetra em seu aspecto de conteúdo-sentido, que reivindica a completa e definitiva autodeterminação na unidade de um determinado domínio de sentido - da ciência, da arte, da história: embora, como mostramos, esses domínios objetivos, fora do ato que os envolve, não são, em si, reais.

(BAKHTIN, 1920-24/2010, p. 42-43 grifo nosso)

A crítica apontada pelo autor diz respeito à problemática cisão que algumas teorias engendram, apartando o conteúdo-sentido do ato de sua realidade histórica, o que levaria a sua total desvalorização, pois perde algo fundamental: a relação com a vivência. A proposta está justamente em unir esses elementos, uma vez que é na

\footnotetext{
${ }^{35}$ Em Português, a obra recebeu o nome de Para uma filosofia do ato responsável (BAKHTIN, 192024/2010).

${ }^{36} \mathrm{O}$ autor faz referência ao pensamento teórico-discursivo, à descrição histórica e à percepção estética.
} 
totalidade do ato que este passa a existir como algo real. O acontecimento é a unidade singular do existir, distante de generalizações teóricas e determinantes, uma vez que estaria em constante vir a ser.

Figura 5: Ato: visão fragmentária e em sua totalidade

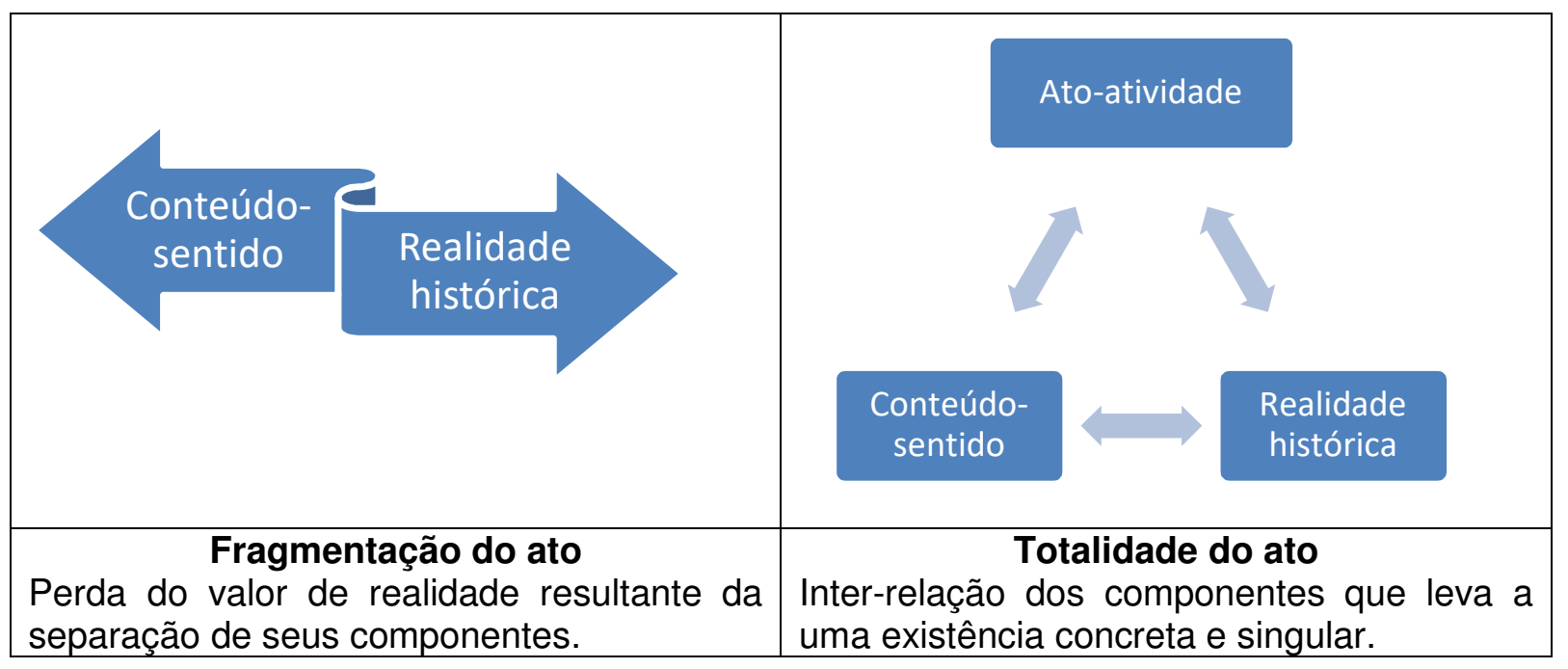

Fonte: Elaborado pela autora.

Para compreendermos o livro didático como acontecimento, retomamos a imagem apresentada por Bakhtin, quando, analisando a obra de Goethe (BAKHTIN, 1979/2011b, p. 239), explica que o olhar deste sobre a natureza não era de mera aceitação de algo pronto e acabado, mas de uma conscientização da inter-relação do tempo e espaço na vida histórica. Assim, mais que simplesmente constatar a existência de bacias aquáticas do país, de seu relevo, de montanhas e obstáculos naturais como algo já dado, Goethe observava esse espaço como algo vivo e dinâmico, perpassado pelo tempo histórico, o tempo do movimento, em que passado e presente estão em constante relação e, por isso, sempre abertos a novas apreciações no interior da atividade histórica do homem.

Se, por um lado, "um pedaço de espaço terrestre deve ser incluído na história da humanidade, fora da qual ele é morto e incompreensível e com ele não há nada a fazer", por outro, Goethe também reconhecia que se fazia fundamental entender que não há nada a fazer com uma lembrança histórica desvinculada de "sua realização em um tempo determinado e em um espaço determinado." 
(BAKHTIN, 1979/2011b, p. 240). Em outras palavras, esses elementos estão sempre imbricados.

A partir dessa análise, podemos repensar nosso olhar frente ao livro didático. No processo de sua produção, o autor ${ }^{37}$ planeja e elabora as atividades didáticas, bem como seleciona os textos que entende serem importantes para a formação do aluno. Isso se dá considerando sua percepção do passado (os valores, enunciados, experiências do qual o sujeito está constituído) e sua percepção do futuro (uma projeção, um plano de como se pretende finalizar a obra) que vai se concretizar de forma material em um acabamento delimitado: o livro didático. Assim, a ação presente está diretamente apontada tanto para o passado (constitutivo do ser), quanto para o futuro (ainda em construção) e esta relação estará de alguma forma materializada fisicamente (portanto, no espaço) na organização proposta pelo autor ao final de sua produção.

A constituição histórico-ideológica do sujeito estará em relação com o tempo e o espaço, num constante ir e vir, considerando que, durante o processo de produção apercepção de futuro (a projeção) pode ser revista e mesmo a percepção de passado (constitutiva do ser) pode ser reelaborada em função do presente. Temos, assim, a primeira aproximação da noção de livro didático como acontecimento, visto ser esse um momento singular, que, apesar de planejado, não tem um caráter pronto e intocável, não é, pois, insensível às características próprias da unicidade do evento.

Ao final de sua elaboração, o livro didático terá um acabamento material delimitado, no entanto, não o poderemos entender, considerando a noção de acontecimento, como produto acabado, pronto e fechado em si. $\mathrm{Na}$ vida, no interior da esfera em que a obra circulará (com suas ideologias, interlocutores e finalidades), esse acabamento será sempre provisório, visto que em contato com os interlocutores (professor, aluno, dirigentes...), também constituídos de sua percepção de passado e de futuro, empreenderão um diálogo constante com o dado (as propostas apresentadas no livro didático), mas participarão como ser-criador, projetando novas relações e novas construções de sentido, num ir e vir constante e nada linear. Esta é a segunda aproximação que vislumbramos ao apresentar o livro

\footnotetext{
${ }^{37}$ Aqui entendido não apenas pela pessoa que assina a obra, mas todo o grupo de profissionais envolvidos no processo que leva a um determinado acabamento do gênero.
} 
didático como acontecimento: no interior do evento, o LD não entendido como algo pronto (ainda que tenha um acabamento) permitiria compreender as possibilidades de novos diálogos que somente a unidade singular do evento proporciona. Assim, a partir dos enunciados presentes na obra, é possível não apenas resgatar valores, mas também reelaborá-los, visto que o sujeito (o homem histórico) contribui para a construção do sentido da obra com sua percepção de passado e suas projeções de futuro em um tempo e espaço determinados.

Tanto quanto Goethe que via a natureza como um espaço vivo e dinâmico, sempre em movimento, entendemos o livro didático nessa mesma relação: um espaço aberto às possibilidades, num espaço e tempo históricos, que só na singularidade da vida e do existir-evento ganha sua completude de sentido.

Entender o livro didático como acontecimento é encará-lo não como algo cuja "existência" é dada, com uma determinada forma e orientações que devem ser seguidas incondicionalmente, mas como mais um diálogo aberto nas diversas situações de interação didática em que ele estiver inserido.

No caso do livro didático de português, isso significa não apenas atender a um propósito didático esperado para a área, mas principalmente reconhecer as especificidades decorrentes do momento de interação não pré-determinado. Além disso, é fundamental compreender a relação "de lugar para lugar, de recanto para recanto e de sala para sala", visto que"o tempo e o senso do tempo mostram diferenças qualitativas e moldam os acontecimentos de maneira similar" (MORSON; EMERSON, 2008, p. 67). Em outras palavras, O LDP, embora tenha seu acabamento, terá novas possiblidades de sentido de acordo com os sujeitos que dele fizer uso em um dado tempo e espaço concretos.

Aproximando a reflexão apresentada nesse tópico à discussão sobre os gêneros orais no LDP, entendemos que encarar o livro didático como acontecimento também nos permite entender de forma singular os usos linguísticos - e suas variações - no momento da produção oral desenvolvida pelo aluno em sala de aula. Dessa forma, é preciso estar atentos que, por mais que o LDP possa apresentar encaminhamentos sobre o que dizer e como dizer (projeção de futuro engendrada pelo autor), esses aspectos estão diretamente ligados à situação concreta e dela não pode ser apartada. Em outras palavras, as orientações didáticas sobre o modo 
de dizer podem ser entendidas como um parâmetro, mas nunca como uma prescrição, pois, se assim for, preso ao "dado", não haverá espaço para o "criado", para o desenvolvimento de um aluno/professor-autor, criador de seu próprio dizer.

\subsection{Unindo a ponta dos fios}

Apresentados de forma isolada, os conceitos aqui elencados podem não dar conta da dinamicidade que engendram para a caracterização do que entendemos como oralidade na perspectiva bakhtiniana. Dessa forma, faz-se necessário sintetizar e amarrar cada um deles de modo a facilitar a compreensão do que buscamos demonstrar.

Primeiramente, deixamos registrado que os conceitos discutidos nesse capítulo também se aplicam ao texto escrito, ou seja, os estudos bakhtinianos evidenciam que a interação verbal acontece não só no diálogo face a face, mas, inclusive, quando o escrevente considera seu interlocutor, sua relação com ele, a situação comunicativa imediata e mais ampla, o tempo sócio-histórico em que se produz o discurso etc. Ele não está, assim, apartado da realização concreta da língua e, por isso, com ela realiza um diálogo constante, que determina, inclusive, suas escolhas linguísticas sobre o dito. Essa forma de dizer, constituída no interior de uma esfera e caracterizada por um gênero discursivo, concretiza-se em forma de um enunciado concreto que, como tal, está carregado de valor axiológico.

Já os enunciados produzidos oralmente no interior de uma dada situação comunicativa também se apresentam dentro de uma interação verbal concreta, com interlocutores que produzem seus enunciados a partir de uma avaliação da situação comunicativa global e que dialogam constantemente com a pequena e a grande temporalidade que envolvem o discurso.

No nosso ponto de vista, as convergências aqui apresentadas só reforçam a tese de uma não oposição entre essas duas formas de materialização do discurso: pelo som ou pela grafia. E, em matéria de ensino, são bastante úteis para levar o aluno a trabalhar com essas formas de realização do texto pelas semelhanças, mais que por suas diferenças. 
Embora sejam nítidas algumas diferenças da situação de produção do discurso oral e do escrito - como a presença/ausência física dos interlocutores no momento da constituição do enunciado - entendemos que o caminho bakhtiniano de trabalho com a linguagem seja mesmo observar, pelo viés dos gêneros discursivos, como esses enunciados constituem-se no momento de interação. Mas, mais do que isso, considerar quais valores estão em diálogo constante nesse processo, interferindo na própria constituição do discurso e, principalmente, na decisão de como ele deve ser apresentado: se oral ou escrito.

Nesta visão, énecessário não esquecer que "os sujeitos que se envolvem nessas relações dialógicas não são entes autônomos e pré-sociais, mas indivíduos socialmente organizados." (FARACO, 2009, p. 121)

Os estudos que tratam das especificidades dos textos no modo de realização oral, apresentando suas marcas linguísticas verbais (repetição, correção, parafraseamento, referenciação), prosódicas (pausas, alongamentos) ou não verbais (olhar, risos, postura do corpo) têm a usa relevância, pois, vistos do interior de um enunciado concreto, darão possibilidade de compreender que a estrutura da língua reflete o evento da inter-relação entre os falantes, ou seja, essas são marcas que podem ajudar a perceber a valoração do enunciado e as relações dialógicas que nele se estabelecem.

Compreendendo que "o estilo se constrói a partir de uma orientação social de caráter apreciativo"(FARACO, 2009, p. 137) que evidencia uma tomada de posição axiológica, o aluno poderá fazer uso da linguagem de forma mais consciente, assumindo efetivamente sua voz e sua posição autoral dentro das mais diversas situações de que participa na vida.

Buscamos, neste capítulo, mostrar como os diversos conceitos bakhtinianos elencados relacionam-se e podem servir de base para a compreensão da oralidade no interior dos estudos do Círculo. Como dissemos, não se trata de negar as concepções desenvolvidas pelos pesquisadores que descreveram algumas marcas linguísticas específicas da oralidade - como vemos, por exemplo, na Gramática do Português culto falado no Brasil -, nem os que trataram da relação da produção oral em sua situação imediata de realização - como se pode observar nos estudos da 
Pragmática e da Análise da Conversação. Na verdade, os estudos bakhtinianos os reconhecem como válidos, mas acrescentam outros aspectos significativos que não podem ficar de fora, como o reconhecimento de que esse dizer dialoga com uma realidade social mais ampla - não aquela apenas imediata - e que está carregado de uma valoração, esta, inclusive, tão fundamental que pode orientar toda a constituição do discurso.

É nesse sentido que o sujeito falante se torna autor, pois é ele que dá forma ao conteúdo e faz escolhas linguísticas refletidas - não aleatórias -, de acordo com sua intencionalidade dentro do grande e do pequeno tempo de sua produção. Revela-se, assim, sua posição axiológica, ou seja, seu posicionamento social ligado a valores construídos na/para a vida. 


\section{CAPÍTULO 3}

\section{A COMPOSIÇÃODO LIVRO DIDÁTICO DE PORTUGUÊS DE ENSINO MÉDIOPARA O PNLD 2015}

Toda a cultura na sua totalidade vem integrada no contexto unitário e singular da vida do qual eu participo. (...) Cada valor que apresente validade geral se torna realmente válido somente em um

contextosingular.

(BAKHTIN, 1920-24/2010, p. 90)

A compreensão do livro didático como um acontecimento nos leva a um distanciamento de generalizações e à busca da singularidade de cada obra. Para esse estudo, destacamos as seguintes especificidades que envolvem nosso corpus: trata-se do livro didático de Português, dirigido ao ensino médio, cujas coleções foram aprovadas no PNLD 2015 e distribuídas a escolas públicas brasileiras.

Considerando essas singularidades, faz-se misterconhecer como elas se constituem, evidenciando as características do ensino médio, do PNLD 2015, do edital que deu base legal a sua realização e do guia do livro didático de português, fruto desse processo. 


\subsection{Esfera escolar: ensino médio em foco}

O livro didático de Português do ensino médioé "historicamente datado, [atende] a interesses de uma esfera de produção e de circulação e, desta situação histórica de produção, retira seus temas, formas de composição e estilo."(BUNZEN e ROJO, 2008, p. 73-74).Assim, entendemos que o LDPsó pode ser compreendido integralmente no interior da esfera em que circula- a escolar - e na relação com a situação sócio-histórica queo constitui.

A esfera escolar é um campo da atividade humana que tem finalidades e características próprias. Nela objetiva-se a aprendizagem e, para tanto, diversos gêneros discursivos são utilizados para atender a este propósito: aula, seminário, prova e, dentre outros, o livro didático. Além disso, o papel dos interlocutores em seu interior também é diverso: aluno, professor, coordenador, diretor, pesquisador, pai de aluno etc. Ao ser produzido um livro didático, tem-se que levar em conta cada um deles, bem como as relações de poder presentes no centro das interações verbais.

Os enunciados produzidos na/para a escola, então, estão em constante diálogo com as condições socioculturais que emergem dessa esfera. Assim, considerando nosso interesse em trabalhar com os livros didáticos de Português do ensino médio, faz-se necessário compreender as especificidades tanto desse nível de ensino, quanto dos documentos oficiais que orientama prática docente e a elaboração de materiais didáticos.

Vale destacar ainda que antes de 2009, o ensino médio não era uma etapa de ensino obrigatória. Apenas após a publicação da lei $n^{\circ}$ 12.061, publicada em 27 de outubro de 2009, foi garantido a todos os cidadãos brasileiros o acesso a esse nível de ensino público e gratuito ${ }^{38}$.

Compreender como se constitui o ensino médio no interior dessa esfera escolar, o que dizem os documentos oficiais voltados para esse nível de ensino e qual a orientação governamental que serve como norte para a produção de materiais didáticos de ensino médio no Brasil é, portanto, relevante para entender a arena de vozes presentes no livro didático de português do ensino médio.

\footnotetext{
${ }^{38} \mathrm{O}$ documento legal que regulamenta essa ação pode ser encontrado no site oficial do planalto. Disponível em: <http://www.planalto.gov.br/ccivil 03/ Ato2007-2010/2009/Lei/L12061.htm>. Acesso em 10/08/2017.
} 


\subsection{Caracterização do ensino médio: documentos oficiais reguladores}

O ensino médio é o período de estudos que ocorre após a formação inicial de nove anos - ensino fundamental - e que antecede a formação universitária. É, pois, o período final da Educação Básica e corresponde a um total de três ou quatro $^{39}$ anos de formação.

Toda a organização dessa etapa escolar - e seus princípios básicos norteadores - está concretizada em diversos documentos oficiais: LDBEN - lei de diretrizes e bases da educação nacional - n9.394/1996 (BRASIL, 1996), DCNEM diretrizes curriculares nacionais para o ensino médio (BRASIL, 1998, 2013a), PCNEM - parâmetros curriculares nacionais do ensino médio (BRASIL, 2000), PCN+ - parâmetros curriculares nacionais mais (BRASIL, 2002), OCEM- orientações curriculares para o ensino médio (BRASIL, 2006).

A LDBEN(n 9.394/1996), documento jurídico, trata da questão da organização mais ampla deste nível de ensino que precede o ensino superior.

Segundo o artigo 35 desta lei, os objetivos do ensino médio estão relacionados tanto ao fortalecimento e ampliação dos estudos realizados no ciclo anterior, quanto à formação do indivíduo, seja para o exercício ético de sua cidadania, seja para a sua preparação para a vida profissional futura.

Art. 35. O ensino médio, etapa final da educação básica, com duração mínima de três anos, terá como finalidades:

I - a consolidação e o aprofundamento dos conhecimentos adquiridos no ensino fundamental, possibilitando o prosseguimento de estudos;

II - a preparação básica para o trabalho e a cidadania do educando, para continuar aprendendo, de modo a ser capaz de se adaptar com flexibilidade a novas condições de ocupação ou aperfeiçoamento posteriores;

III - o aprimoramento do educando como pessoa humana, incluindo a formação ética e o desenvolvimento da autonomia intelectual e do pensamento crítico;

IV - a compreensão dos fundamentos científico-tecnológicos dos processos produtivos, relacionando a teoria com a prática, no ensino de cada disciplina.

(BRASIL, 1996, p. 13-14)

\footnotetext{
${ }^{39} \mathrm{O}$ ensino médio de quatro anos ocorre geralmente em cursos técnicos que têm como meta a formação profissional do aluno. Nos demais, cujo objetivo não está ligado à profissionalização, o período de estudos é de três anos.
} 
Sua organização tem como proposta um trabalho interdisciplinar e contextualizado, em busca de um ensino menos compartimentado. Para atingir esse objetivo, a partir de 1996 uma nova estruturação foi proposta no documento e o EM passou a ser organizado por três áreas de conhecimento: (1) Linguagens, códigos e suas tecnologias; (2) Ciências da Natureza, Matemática e suas tecnologias; e (3) Ciências Humanas e suas tecnologias.

Corroborando as LDBEN, as diretrizes curriculares para o ensino médio DCNEM $(1998 ; 2013 a)$ - reforçam esse caráter mais contextualizado de ensino. Elas são um documento jurídico oficial, com artigos e incisos que regulam as principais ações do ensino médio. Com força de lei, as DCNEM são revistas e reelaboradas sempre que são propostas mudanças para esse nível de ensino.

Os PCNEM (2000), à época de sua publicação, tiveram um caráter orientador, com vistas a fornecer um suporte para que a escola elaborasse seu currículo, estabelecendo limites e condições para que ele pudesse ser desenvolvido. Ao retomar a nova organização proposta nas DCEM, por exemplo, esse documento evidenciouo grupo de disciplinas relativos a cada área e apresentou as competências e habilidades específicas que devem ser desenvolvidas.

Tabela 8: Relação área / disciplina / competênciae habilidade - Ensino médio

\begin{tabular}{|c|c|c|}
\hline Área & Disciplinas & Habilidade / competência \\
\hline $\begin{array}{l}\text { Linguagens, códigos e } \\
\text { suas tecnologias }\end{array}$ & $\begin{array}{l}\text { Língua Portuguesa } \\
\text { Língua estrangeira moderna } \\
\text { (inglês / espanhol) } \\
\text { Artes } \\
\text { Educação Física }\end{array}$ & Representação e comunicação \\
\hline $\begin{array}{l}\text { Ciências da natureza, } \\
\text { matemática e suas } \\
\text { tecnologias }\end{array}$ & $\begin{array}{l}\text { Matemática } \\
\text { Física } \\
\text { Química } \\
\text { Biologia }\end{array}$ & Investigação e compreensão \\
\hline $\begin{array}{l}\text { Ciências humanas e suas } \\
\text { tecnologias }\end{array}$ & $\begin{array}{l}\text { História } \\
\text { Geografia } \\
\text { Filosofia } \\
\text { Sociologia }\end{array}$ & Contextualização sócio-cultural \\
\hline
\end{tabular}

Fonte: BRASIL, 2000. 
Segundo os PCNEM (BRASIL, 2000), as competências que se referem a cada uma das áreas do conhecimento não são exclusivas, mas apenas prioritárias. Isso implica perceber a intenção de um não isolamento das habilidades, com vistas, inclusive a uma maior dinâmica no ensino: menos conteudista e mais engendrado. Assim, a "comunicação", mesmo sendo uma competência a ser desenvolvida prioritariamente na área de "Linguagens, códigos e suas tecnologias", não deixa de ser importante para as demais áreas, as quais também devem explorá-la, considerando as especificidades e objetivos das disciplinas.

O foco dessa nova forma de organização é uma aprendizagem global, em que o aluno compreenda que existem aspectos que são relevantes não apenas em uma disciplina, mas em um conjunto delas, e, mais ainda, no conhecimento como um todo. É, portanto, uma proposta interdisciplinar e contextualizada de ensino.

Embora nas escolas as aulas continuem divididas em disciplinas, a proposta apresentada para o trabalho por áreas é evidenciar a interligação entre elas. Assim, para o ensino de Língua Portuguesa, é possível explorar aspectos ligados às linguagens presentes nos estudos de outras línguas, da materialidade de obras de arte e mesmo dos movimentos de expressão corporal, que não deixam de comunicar e representar algo.

As DCNEM de 2013 alertam, no entanto, que essa estruturação, visando a uma articulação entre as diferentes disciplinas de uma mesma área no interior das unidades escolares, tiveram pouca ressonância na prática:

Mesmo considerando o tratamento dado ao trabalho didático-
pedagógico, com as possibilidades de organização do Ensino Médio,
tem-se a percepção que tal discussão não chegou às escolas,
mantendo-se atenção extrema no tratamento de conteúdos sem a
articulação com o contexto do estudante e com os demais
componentes das áreas de conhecimento e sem aproximar-se das
finalidades propostas para a etapa de ensino, constantes na LDB. Foi
observado em estudo promovido pela UNESCO [2009], que inclui
estudos de caso em dois Estados, que os ditames legais e
normativos e as concepções teóricas, mesmo quando assumidas
pelos órgãos centrais de uma Secretaria Estadual de Educação, têm
fraca ressonância nas escolas e até, pouca ou nenhuma, na atuação
dos professores. BRASIL, 2013a, p. 154. 
Em relação ao trabalho com oralidade, os PCNEM (BRASIL, 2000) defendiam que era necessário dar espaço para que o aluno pudesse falar e expressar suas opiniões e pontos de vista. No entanto, não ficou claro de que forma esse trabalho poderia ser feito.

A leitura desse documento demandou do professor um conhecimento teórico específico - relacionado à teoria bakhtiniana - e, assim, não surtiu tanto efeito para a prática docente, como esperado à época de sua divulgação.

As críticas sofridaspelos PCNEM, considerado muito genérico e pouco esclarecedor, especialmente por assumir uma base teórica ainda pouco conhecida, à época, pelos professores (SOUZA NETO, 2014), levou o MEC a publicar um novo documento, os PCN+ (2002), que, como apresentado no subtítulo do documento, teria a função de trazer "orientações educacionais complementares aos Parâmetros Curriculares Nacionais" de ensino médio.

Em relação ao trabalho com gêneros orais, por exemplo, os PCN+ (BRASIL, 2002) buscaram então preencher uma lacuna dos PCNEM, que não tratavam o enfoque da oralidade de forma explícita. Nesse documento, a presença da palavra gênero é bem mais recorrente. Além disso, não apenas podemos encontrar termos como "gênero oral", "texto oral", "texto falado", "oralidade", como há indicações de alguns exemplares deles: debate regrado, canção, entrevista etc.

No plano da oralidade, nas situações de escuta, isso implica que o aluno tenhauma atitude responsiva ativa, sabendo dialogar internamente com o que ouve para, eventualmente, intervir na situação e produzir seu texto oral.

Finalmente, propõe-se que a disciplina Língua Portuguesa abra espaço paradiferentes abordagens do conhecimento. Ainda que a palavra escrita ocupe umespaço privilegiado na disciplina, é possível que a produção de textos faladosganhe uma sistematização maior, por meio de gêneros orais como a mesaredonda,o debate regrado, o seminário, o programa radiofônico, para citarapenas alguns exemplos.

(BRASIL, 2002, p. 64 e 71. Ênfase nossa.) 
Os PCN+ trazemexplícita, ainda, a informação de que a conceituação, identificação de intenções e situações de uso referente à língua falada é uma competência a ser desenvolvida pelo aluno do EM, o que coloca como central o estudo de uma língua viva, ligado a uma prática concreta dentro de interações sociais.

Uma das diferenças que se observa entre os PCNEM e os PCN+ é o fato de que este último acrescenta três competências a serem desenvolvidas pelo aluno: a interativa, textual e gramatical. A primeira diz respeito aos usos efetivos da língua em situação real de interação. A segunda reforça a ideia de que é por meio de textos - orais ou escritos - que o ensino deve ser pensado, visto que 0 aluno precisa compreender as relações entre textos e seus usos concretos. A terceira enfoca a importância do conhecimento gramatical como meio para o uso efetivo da língua, nas suas duas modalidades. Assim, o estudo de gêneros orais encontra espaço garantido, visto que eles estão presentes em diversas situações de interação social.

Os PCN+ tinham a missão de sanar as lacunas do documento anterior, no entanto, mostraram-se insuficientes, inclusive por apresentarem algumas contradições (SOUZA NETO, 2014) em relação ao que havia sido proposto nos PCNEM.

Nointuito de dar voz aos professores, secretarias de ensino e pesquisadores que atuam na área da educação, o MEC iniciou em 2004 um debate sobre questões relacionadas ao currículo escolar e a cada disciplina do ensino médio. Como resultado dessa discussão, em 2006, foram publicadas as orientações curriculares para o ensino médio - OCEM -, em três volumes, cada qual referente a uma das áreas de ensino em que esse nível de ensino está constituído. Esse novo documento, tinha o intuito de trazer indicações didático-pedagógicas mais pontuais para o ensino médio brasileiro.

A linguagem demasiadamente teórica dos PCNEM e o teor prescritivo dos $\mathrm{PCN}+$ Ensino Médio fizeram com que esses documentos perdessem visibilidade ao longo dos anos, gerando, assim, a necessidade da elaboração das Orientações Curriculares para o Ensino Médio. 
As OCEM, criadas como objetivo "atender às necessidades e às expectativas das escolas e dos professores na estruturação do currículo para o ensino médio" (BRASIL, 2006, p. 8), são atualmente o principal documento regular do ensino médio brasileiro.

Para nosso estudo, tomamos o volume 1 desse documento (BRASIL, 2006) como referência, visto ser este o que trata da área de Linguagens, códigos e suas tecnologias, onde está situada a disciplina de Língua Portuguesa. Na "carta ao professor", que introduz as orientações aos professores está declarado que o objetivo do documento é "contribuir para o diálogo entre professor e escola sobre a prática docente". (BRASIL, 2006, p. 5)

A concepção de língua aí explicitada evidencia uma preocupação com "práticas sociais de produção e recepção de texto", considerando uma abordagem interacionista, a qual defende que "todo e qualquer texto se constrói na interação".(BRASIL, 2006, p. 23)

As OCEM esclarecem, ainda, tanto as correntes teóricas que dão base à vertente adotada, como cita alguns estudiosos de cada uma delas. Nesse sentido, foram considerados os estudos da linguística (Hymes), da filosofia da linguagem (Bakhtin), da etnometodologia e sociologia (Goffman), da psicologia (Bronckart), da educação (Schneuwly) e da psicologia do desenvolvimento (Vygotsky).

A proposta de trabalho indicada no documento pode possibilitar o desenvolvimento de letramentos múltiplos, como uma tentativa de não fragmentar o conhecimento e como estratégia para a inclusão social mais ampla.

(...) defende-se que a abordagem do letramento deve, portanto, considerar as práticas de linguagem que envolvem a palavra escrita e/ou diferentes sistemas semióticos - seja em contextos escolares seja em contextos não escolares -, prevendo, assim, diferentes níveis e tipos de habilidades, bem como diferentes formas de interação e, consequentemente, pressupondo as implicações ideológicas daí decorrentes.

BRASIL, 2006, p. 28.

Osugestão de estudo do eixo da oralidade, nesse documento, ressalta a necessidade de se trabalhar as modalidades oral e escrita em sua relação, ou seja, 
compreendendo as especificidades de cada uma, mas reconhecendo as aproximações possíveis entre elas.

Além disso, enfatiza a proposição de uma produção de texto oral que considere as situações mais formais de interação, o que reforça a relevância do estudo de gêneros como debate, entrevista, mesa-redonda, dentre outros. O foco desse estudo seria pautado em análises linguísticas menos descritivas e mais reflexivas, a fim de que o aluno possa compreender um determinado uso da língua em relação ao gênero e à situação em que se deu o discurso.

Segundo esse documento, três atividades devem ser consideradas com 0 trabalho com gêneros orais na escola: (1) produção; (2) escuta; (3) análise linguística. Incluindo-se nesta última propostas de atividades de retextualização.

(...) por força das orientações contidas nos diferentes documentos de parametrização, construídos nos últimos anos e em consonância, ainda que parcialmente, com estudos produzidos pela Análise da Conversação, pela Linguística Textual e pelas Teorias da Enunciação, ganham cada vez mais espaço, nessa proposta, atividades de produção, recepção e análise de textos orais, obviamente fora da orientação dicotômica e oposicionista - em relação à escrita -, que vigorou na universidade e na escola durante muitas décadas. Sob essa lógica, pretende-se que o estudante veja a fala e a escrita como modalidades de uso da língua complementares e interativas, sobretudo quando levam em conta práticas de linguagem nascidas na/da tecnologia digital, que também permitem a recorrência on-line desses dois tipos de modalidade.

BRASIL, 2006, p. 34. (Ênfase nossa)

As propostas apresentadas pelas OCEM em relação ao trabalho com a oralidadeestão distribuídas ao longo do documento. Algumas competências e habilidades são significativas para a compreensão desse eixo de ensino, as quais sintetizamos as seguir. 
Tabela 9:Oralidade no ensino médio - proposta das OCEM

\begin{tabular}{ll}
\hline Eixo norteador & Competência / habilidade a ser desenvolvida \\
\hline Produção & $\begin{array}{l}\text { Utilizar gêneros orais diversos no interior de práticas sociais. } \\
\text { Reconhecer o papel do contexto para as escolhas linguísticas. } \\
\text { Realizar atividades de retextualização (oral para o escrito e vice-versa) }\end{array}$ \\
Recepção & $\begin{array}{l}\text { Desenvolver capacidade de escuta, favorecendo a concentração e percepção. } \\
\text { Compreender os textos escutados e interagir com eles de forma ativa. }\end{array}$ \\
Análise & $\begin{array}{l}\text { Observar as relações estabelecidas entre os sujeitos e seus papeis sociais. } \\
\text { Perceber a relação entre o uso da língua e o contexto imediato / mais amplo. } \\
\text { Reconhecer as valorações ideológicas que envolvem o momento de produção. } \\
\text { Compreender os usos linguísticos:sua variedade de acordo com a situação. }\end{array}$
\end{tabular}

Fonte: BRASIL, 2006.

Todo o panorama apresentado nos documentos oficiais dialogacom o LDPEM. As vozes destas orientações ecoam nas atividades propostas para os alunos no intuito de se fazer cumprir o que é proposto oficialmente pelo governo federal brasileiro. Apontaremos no capítulo de análise como isso se realiza.

\subsection{Programa Nacional do Livro Didático para o Ensino Médio}

No processo de escrita do LDP-EM, voltado para as escolas públicas, levase em conta não apenas o público-alvo desse nível de ensino e os referenciais oficiais estabelecidos pelo governo, mas também os critérios considerados relevantes para definir a qualidade da proposta didática. Esta avaliação é realizada no âmbito do Programa Nacional do Livro Didático (PNLD), sob a responsabilidade do Ministério da Educação e Cultura (MEC), a partir de dois órgãos: Fundo Nacional de Desenvolvimento da Educação (FNDE) e Secretaria de Educação Básica (SEB).

O objetivo do programa é realizar uma prévia avaliação de obras didáticas visando à distribuição gratuita de materiais de qualidade para as escolas públicas brasileiras ${ }^{40}$.

O processo de avaliação ocorre em seis etapas: (1) divulgação do edital de convocação; (2) inscrição das coleções que serão à avaliadas; (3) triagem destas

\footnotetext{
${ }^{40}$ Uma leitura diacrônica de todo o percurso desse programa pode ser encontrado no site do FNDE (BRASIL, 2017a), no link "histórico": <http://www.fnde.gov.br/programas/livro-didatico/livro-didaticohistorico>.
} 
considerando critérios materiais pré-estabelecidos no edital; (4) préanálise, seguida pela avaliação pedagógica propriamente dita; (5) elaboração, pela equipe de avaliadores, do guia de livros didáticos; e (6) escolha das obras pelos professores de escolas públicas de todo o país.

Há ainda uma etapa que precede esse processo de avaliação geral no conjunto das ações do poder público: é a adesão das escolas ao programa, passo anterior à publicação do edital.

As escolas federais e os sistemas de ensino estaduais, municipais e do Distrito Federal que desejem participar dos programas de material didático deverão manifestar este interesse mediante adesão formal, observados os prazos, normas, obrigações e procedimentos estabelecidos pelo Ministério da Educação. O termo de adesão deve ser encaminhado uma única vez. Os beneficiários que não desejarem mais receber os livros didáticos precisam solicitar a suspensão das remessas de material ou a sua exclusão do(s) programa(s). A adesão deve ser atualizada sempre até o final do mês de maio do ano anterior àquele em que a entidade deseja ser atendida.

$(\text { BRASIL, 2017b) })^{41}$

Após a escolha das obras realizada pelos professores nas escolas, mais seis etapas são cumpridas para que efetivamente o livro possa ser utilizado: (1) pedido das obras formalizado ao FNDE; (2) aquisição junto às editoras, ocasião em que são realizadas as negociações de valores entre as partes; (3) produção do material considerando a quantidade solicitada pelo governo; (4) análise de qualidade física do material entregue, realizado pelo IPT (Instituto de Pesquisas Tecnológicas); (5) distribuição dos livros nas escolas realizada pelos correios; (6) recebimento nas escolas, que se dá entre o outubro do ano anterior e o início do período letivo. (BRASIL, 2017b)

Embora a proposta de distribuição de livros didáticos não seja algo tão recente como política pública, visto que em 1937 já se tem registro de ações dessa natureza, o PNLD, com essa nomenclatura, teve início em 1996, ocasião em que

\footnotetext{
41 Informação presente em ambiente digital, por isso não há paginação. Disponível em: $<$ http://www.fnde.gov.br/programas/programas-do-livro/livro-didatico/funcionamento>. Acesso em 10/03/2017.
} 
apenas os livros didáticos de $1^{\text {a }}$ a $4^{\text {a }}$ séries ${ }^{42}$ foram avaliados. Neste mesmo ano houve a publicação do primeiro Guia de Livros Didáticos, cuja importância trataremos adiante.

Campos (2014, p. 37) afirma que "os programas de livros desenvolvidos entre 1968 e 1988 não tiveram impacto exatamente sobre o projeto pedagógico do livro, porque não traziam critérios explícitos nesse sentido", fato que em 1996 fica resolvido com a publicação de um edital.

A autora esclarece que é possível observar uma relação entre esses anos e os subsequentes se considerarmos a própria transição política da época, vinda de um longo período de ditadura (1964-1985), seguida pela promulgação da nova constituição brasileira em $1988^{43}$, pelas primeiras eleições diretas (1989) e pela sanção da Lei 9394/96 da LDBEN em 1996, após longas discussões realizadas desde 1988. Esta lei, ainda em vigor, colocou o ensino médio como parte da educação básica e, como tal, com direitos a receber recursos próprios. Fato que possibilitou sua inserção no programa de avaliação de livros didáticos posteriormente(CAMPOS, 2014).

Batista (2003) também apresenta um histórico desse programa evidenciando as principais ações do PNLD até 2002. Segundo ele, até aquele ano, diferentemente do que foram os anos apontados por Campos (2014), os resultados eram bastante positivos, tanto por contribuir para uma mudança de mentalidade, junto às editoras, no intuito de produzirem obras de melhor qualidade, quanto por permitirem uma mudança de olhar na escola, em relação às práticas de ensino.

(...) o PNLD vem contribuindo para um ensino de melhor qualidade: é uma referência consensual de qualidade para a produção de livros didáticos e para sua escolha, por professores; vem possibilitando uma reformulação dos padrões do manual escolar brasileiro e criando condições adequadas para a renovação das práticas de ensino nas escolas.

(BATISTA, 2003, p. 41)

\footnotetext{
${ }^{42}$ Atualmente, essas séries equivalem aos $1^{\circ}$ a $5^{\circ}$ anos do Ensino Fundamental.

${ }^{43}$ Fatos importantes na história do país e que estão ligados a esse período são: Lei da anistia (1979), Diretas Já (1984), Eleição de um presidente civil (1985); Nova constituinte (1988); primeiras eleições diretas (1989).
} 
Até o ano de 2002, estavam incluídas nas avaliações as obras didáticas voltadas apenas para o Ensino Fundamental I e II, de diversas disciplinas. Além de dicionários de Língua Portuguesa e atlas geográficos. As coleções voltadas para o ensino médio começaram a ser incluídas apenas em 2003, a partir da resolução CD FNDE $n^{\circ} 38$, de 15/10/2003. Este PNLD voltado para o ensino médio foi nomeado, à época, como PNLEM, nomenclatura usada de 2004 a 2008. (BRASIL, 2017a).

O início do processo de avaliação das obras didáticas voltadas para esse segmento de ensino ocorreu em 2004, com o PNLEM 2005. Este primeiro PNLEM, no entanto, não se deu de forma integral, visto que apenas as obras de Português e Matemática, da $1^{a}$ série do ensino médio, foram distribuídas. Além disso, esta distribuição não se deu em todo território nacional, apenas nas regiões Norte e Nordeste do Brasil.

No ano seguinte - 2005 -, todas as regiões do país passaram a ser atendidas e incluiu-se também a distribuição para todos os anos do ensino médio. As disciplinas, no entanto, estavam circunscritas a Português e Matemática.

Entre 2004 e 2007, as distribuições ocorreram de forma parcial, pois, a cada PNLEM eram incluídas novas disciplinas da grade curricular. Nos dois primeiros anos apenas os livros de Português e Matemática foram disponibilizados. Em 2006, incluíram-se os livros de Biologia e, em 2007, os de História e Química.

A distribuição integral de obras de todas as disciplinas só ocorreu em 2008, no PNLEM 2009, ocasião em que, além das disciplinas já citadas, foram entregues obras de Física e Geografia em todo o território nacional.

No ano seguinte (2009), as disciplinas de língua estrangeira (Inglês / Espanhol), Filosofia e Sociologia também passaram a integrar o programa. No entanto, com um diferencial: as obras eram consumíveis ${ }^{44}$ e em volume único ${ }^{45}$.

\footnotetext{
${ }^{44}$ O livro consumível é aquele em que o aluno pode escrever nas páginas da obra. Como não é possível reutilizar em anos posteriores, entende-se que ele foi "consumido", ou seja, usado. Essa terminologia é usada em oposição ao livro não-consumível, aquele que os alunos fazem uso durante um ano letivo, mas que devem preservar de tal forma que ele possa ser reutilizado por outros alunos em anos posteriores. Todas as disciplinas (Português, Matemática, História, Geografia, Biologia, Física e Química) são não-consumíveis. Apenas Filosofia, Sociologia e Língua Estrangeira (Inglês / Espanhol) fogem a essa regra.

${ }^{45}$ As demais disciplinas apresentavam obras com três volumes, um para cada ano do ensino médio.
} 
O uso do termo PNLEM para fazer referência ao PNLD voltado para o ensino médio foi usado apenas de 2004 a 2008 (PNLEM 2005 a 2009). A partir de 2009, com o PNLD 2010, não houve mais essa distinção, sendo todas as avaliações designadas pela sigla que recupera as iniciais do Programa Nacional do Livro Didático: PNLD.

O PNLD 2011, em 2010, focou na reposição e complementação das obras já aprovadas anteriormente. Uma nova avaliação dos livros didáticos foi realizada em 2011, por ocasião do PNLD 2012, ocasião em que se incluiu a entrega de obras na modalidade de Educação de Jovens e Adultos (EJA).

O diferencial do PNLD 2015 46 , a partir do qual selecionamos as obras a serem analisadas nesta tese, é o fato de trazer, pela primeira vez para o ensino médio, a oportunização de entrega de livro digital, ou seja, além do livro impresso, as editoras poderiam entregar uma obra multimídia ${ }^{47}$, com o mesmo conteúdo do livro em papel, mas com o acréscimo de atividades interativas para serem realizadas pelos alunos.

(...) para o ano letivo de 2015, foi lançado em 2012 [sic] o edital ${ }^{48}$ que prevê que as editoras podem apresentar obras multimídia, reunindo livro impresso e livro digital. A versão digital deve trazer o mesmo conteúdo do material impresso mais os objetos educacionais digitais, como vídeos, animações, simuladores, imagens, jogos, textos, entre outros itens para auxiliar na aprendizagem. O edital também permite a apresentação de obras somente na versão impressa, para viabilizar a participação das editoras que ainda não dominam as novas tecnologias. Esse material será destinado aos alunos e professores do ensino médio da rede pública.

(BRASIL, 2017a ${ }^{49}$ )

\footnotetext{
${ }^{46}$ Os PNLD 2013 e 2014, realizados em 2012 e 2013, referiam-se às séries iniciais (1ํa a $5^{\circ}$ anos) e finais $\left(6^{\circ}\right.$ ao $\left.9^{\circ}\right)$ do Ensino Fundamental, respectivamente. Como optamos por focar no histórico do ensino médio, não os mencionamos no corpo deste trabalho.

${ }^{47}$ Vale destacar que o Edital deste PNLD foi divulgado em 2013 e as obras foram avaliadas em 2014. Houve, portanto, pouco tempo para a adequação a essaorientação. Talvez por isso, das dez obras aprovadas, apenas uma atende a esse perfil tecnológico.

48 O Edital de convocção do PNLD 2015 foi publicado em 2013. A informação que aparece nessa citação, fazendo referência a 2012, deve ter sido colocada por engano.

${ }^{49}$ Não há paginação para essa citação, porque o fragmento foi retirado do site do FNDE. Disponível em <http://www.fnde.gov.br/programas/programas-do-livro/livro-didatico/historico>. Acesso em 10/08/2017.
} 
Neste ano de 2017, foi realizado o PNLD 2018, cujo edital foi publicado em 2016 e que focaliza a avaliação de obras do Ensino Médio que serão distribuídas nas escolas públicas de todo país no ano de 2018.

Para sintetizar o percurso histórico do PNLD voltado para a avaliação das obras didáticas do Ensino Médio, para a disciplina de Português, organizamos a tabela a seguir.

\section{Tabela 10:Avaliação de livros didáticos de Português do ensino médio}

\section{Histórico do programa nacional do livro didático de ensino médio - de 2005 a 2018}

\begin{tabular}{|c|c|c|c|}
\hline Avaliação & $\begin{array}{l}\text { Ano do } \\
\text { edital }\end{array}$ & $\begin{array}{l}\text { Ano de } \\
\text { realização }\end{array}$ & Obras distribuídas \\
\hline PNLEM 2005 & 2003 & 2004 & $\begin{array}{l}\text { Português (avaliação parcial e compra - } 1^{a} \text { série do E.M). } \\
\text { Entrega para Norte e Nordeste do Brasil. }\end{array}$ \\
\hline PNLEM 2006 & 2004 & 2005 & $\begin{array}{l}\text { Português (avaliação integral e compra) } \\
\text { Entrega para todos os estados e todas as séries. }\end{array}$ \\
\hline PNLEM 2007 & 2005 & 2006 & Português (reposição). \\
\hline PNLEM 2008 & 2006 & 2007 & Português (reposição). \\
\hline PNLEM 2009 & 2007 & 2008 & Português (reposição). \\
\hline PNLD 2010 & 2008 & 2009 & Português (reposição). \\
\hline PNLD 2011 & 2009 & 2010 & Português (reposição). \\
\hline $\begin{array}{l}\text { PNLD } 2012 \\
\text { PNLD } 2015\end{array}$ & $\begin{array}{l}2010 \\
2013\end{array}$ & $\begin{array}{l}2011 \\
2014\end{array}$ & $\begin{array}{l}\text { Português (nova avaliação - compra integral). } \\
\text { Português (nova avaliação - compra integral). } \\
\text { Diferencial: obras multimídias (livro digital). }\end{array}$ \\
\hline PNLD 2018 & 2016 & 2017 & $\begin{array}{l}\text { Português (nova avaliação - compra integral). } \\
\text { Diferencial: avaliadores foram pesquisadores ou } \\
\text { professores da educação básica. }\end{array}$ \\
\hline
\end{tabular}

Fonte: BRASIL, 2017.

Focalizamos, nessa tese, apenas as avaliações do PNLD ligadas às obras do ensino médio de português, por ser esse o recorte de nosso estudo. O programa, no entanto, assumiu uma abrangência maior, atendendo todos os níveis de escolarização, de todas as disciplinas, inclusive de educação de jovens e adultos e a educação do campo. O programa, portanto, foi e é ainda bastante relevante no cenário de políticas públicas da educação nacional. 


\subsubsection{Edital de convocação do PNLD $2015^{50}$}

O documento oficial que dá início ao processo de avaliação dos livros didáticos proposto pelo MEC é o edital de convocação, divulgado no site do FNDE, a cada edição. É a partir desta publicação que se dá início à inscrição das coleções. Essa convocação ocorre, como observamos anteriormente, dois anos antes de as obras serem efetivamente distribuídas nas escolas. Assim, para o PNLD 2015, as inscrições iniciaram-se em 2013.

O Edital de convocação do PNLD 2015 possui 84 páginas e nele há informações sobre prazos, características das obras, critérios e procedimentos para participação, detalhamento do processo de avaliação, incluindo os critérios de análise, explicações sobre a elaboração do Guia de Livros Didáticos ${ }^{51}$ e de como se dará o processo de seleção das obras nas escolas posteriormente. Além disso, são apresentados os passos para aquisição, produção e distribuição das obras, bem como doze anexos com documentos ou orientações para as editoras.

Assim, há nele três discursos coexistindo: o técnico, o jurídico e o pedagógico.

O primeiro - técnico - refere-se às orientações físicas de produção do material, como a qualidade do papel, o formato do livro, seu acabamento, entre outros. Estes aspectos são avaliados pelo IPT (Instituto de Pesquisa e Tecnologia) e visam garantir que a obra dure três anos, visto ser esse o período de utilização das obras a cada edição.

O segundo - jurídico - norteia a validade da ação a partir de declarações presentes no anexo do documento - para que as editoras atestem: (a) edição; (b) originalidade; (c) primeira avaliação; (d) reinscrição; (e) revisão e atualização da obra / objetos educacionais digitais; ( $f$ ) correção (quando for obra reinscrita) dos materiais entregues; (g) titularidade de direito patrimonial; e (h) habilitação para participar do processo.A observância às normas oficiais relativas ao ensino médio, como respeito à LDBEN, ao Estatuto da Criança e do Adolescente (ECA), às diretrizes curriculares também evidenciam a presença do discurso jurídico no documento.

\footnotetext{
${ }^{50}$ Doravante, Edital.

${ }^{51}$ Doravante, Guia.
} 
O terceiro - pedagógico -está relacionado às questões teóricometodológicas imprescindíveis às propostas didáticas, bem como o respeito ao cidadão de forma a coibir visões preconceituosas, a fuga aos princípios éticos,a inadequação didático-pedagógica da obra, a incoerência entre o que foi declarado no manual e o que o LD de fato apresenta e, por fim,o não estímulo a uma visão interdisciplinar na abordagem do conteúdo.

Todas as informações sobre prazos estão explicitados no Edital. Assim, para o PNLD 2015, as editoras tiveram que seguir o seguinte cronograma.

\section{Tabela 11 - Prazos declarados no Edital de convocação do PNLD 2015}

\begin{tabular}{cccl}
\hline $\begin{array}{c}\text { Data } \\
\text { Inicial }\end{array}$ & $\begin{array}{c}\text { Data } \\
\text { final }\end{array}$ & $\begin{array}{c}\text { Período } \\
\text { total }\end{array}$ & Ação a ser realizada \\
\hline $21 / 01 / 2013$ & $21 / 06 / 2013$ & 5 meses & $\begin{array}{l}\text { Cadastramento de editores e pré-inscrição de obras } \\
\text { didáticas. }\end{array}$ \\
\hline $01 / 07 / 2013$ & $05 / 07 / 2013$ & 5 dias & $\begin{array}{l}\text { Inscrição / entrega dos livros impressos e } \\
\text { documentação } \\
\text { Inscrição / entrega dos livros digitais }\end{array}$ \\
\hline $19 / 08 / 2013$ & $23 / 08 / 2013$ & 5 dias & \\
\hline
\end{tabular}

Fonte $^{52}$ : BRASIL, 2013b, p. 1

Neste cronograma é possível observar uma abertura para entrega de livros digitais, um diferencial da edição de 2015 em relação às edições anteriores: esse foi o primeiro PNLD em que as obras impressas poderiam ser acompanhadas de recursos digitais, as OED's - Objetos Educacionais Digitais ${ }^{53}$, conforme apresentado no histórico presente no tópico anterior. As editoras tiveram cinco dias, no mês de agosto de 2013, para entregar esse material. No Edital, fica claro, porém, que esta era uma opção da editora e não uma obrigatoriedade. Assim, de acordo com a escolha feita, as obras foram classificadas em "tipo 1" (quando faziam uso de OED's) ou "tipo 2" (quando apenas disponibilizavam uma versão PDF da obra impressa).

\footnotetext{
${ }^{52}$ Tabela elaborada por nós com base no item 2 do Edital de convocação do PNLD 2015, para o processo de inscrição e avaliação de obras didáticas a serem usadas de 2015 a 2017. (BRASIL, 2013b).

${ }^{53}$ De acordo com o item 4.2.3 do Edital: "Entende-se por objetos educacionais [digitais] vídeos, imagens, áudios, textos, gráficos, tabelas, tutoriais, aplicações, mapas, jogos educacionais, animações, infográficos, páginas web e outros elementos." (BRASIL, 2013b, p. 3)
} 
3. Das Obras Didáticas

3.1. As obras didáticas deverão ser inscritas em um dos seguintes tipos de composição:

3.1.1. Tipo 1: Obra Multimídia composta de livros digitais e livros impressos.

3.1.2. Tipo 2: Obra Impressa composta de livros impressos e PDF.

(BRASIL, 2013, p. 1, ênfase nossa)

Apesar de a abertura do uso de OED's ter sido um avanço no que se refere à ampliação do trabalho que o livro didático poderia oferecer - inclusive para o estudo da oralidade -, o Guia de livros didáticos ${ }^{54}$ (BRASIL, 2014) declara que apenas uma dentre as dez obras aprovadas no PNLD 2015 foi inscrita como obra do tipo 1, o que é, a nosso ver, uma adesão bastante diminuta.

No que tange à avaliação dos livros didáticos, o Edital orienta a entrega de dez exemplares, sendo seis caracterizados e quatro descaracterizados. Essas designações fazem referência ao fato de haver parte das obras em que as informações de título da obra, de editora e de autoria estão explicitadas na capa dos volumes (caracterizados) e outras em que seja feito um apagamento desses dados, mantendo apenas a indicação de componente curricular, ano ou ciclo de ensino e indicação de "manual do professor" (descaracterizados).

Essa estratégia garante maior clareza ao processo, visto que o avaliador terá acesso apenas às obras descaracterizadas e, por isso, seu julgamento dar-se-á apenas em relação à proposta pedagógica e não quanto aos seus conhecimentos prévios em relação ao autor, à editora ou ao título da coleção. As coleções caracterizadas só serão disponibilizadas aos coordenadores de cada equipe, visto serem deles a tarefa de fazer a triagem inicial das obras, antes do processo de avaliação propriamente dito.

Os critérios de avaliação, também estabelecidos no Edital, evidenciam os itens eliminatórios (a) comuns a todas as áreas; (b) específicos de cada área; e (c) específicos do componente de Língua Portuguesa.

\footnotetext{
${ }^{54}$ Sobre o Guia de livros didáticos, documento produzido pelos avaliadores do PNLD com resenhas das obras aprovadas para facilitar a escolha dos professores nas escolas públicas, trataremos no próximo tópico deste capítulo.
} 
No que tange aos critérios eliminatórios comuns de todas as áreas, é possível observar que eles enfatizam que as obras voltadas para o ensino médio devem respeitar a legislação, serem coerentes em relação à proposta apresentada e não ferirem princípios éticos do cidadão.

Os critérios eliminatórios comuns a serem observados nas obras inscritas no PNLD 2015, submetidas à avaliação, são os seguintes:

(1) respeito à legislação, às diretrizes e às normas oficiais relativas ao ensino médio;

(2) observância de princípios éticos necessários à construção da cidadania e ao convívio social republicano;

(3) coerência e adequação da abordagem teórico-metodológica assumida pela obra no que diz respeito à proposta didáticopedagógica explicitada e aos objetivos visados;

(4) respeito à perspectiva interdisciplinar na apresentação e abordagem dos conteúdos;

(5) correção e atualização de conceitos, informações e procedimentos;

(6) observância das características e finalidades específicas do manual do professor e adequação da obra à linha pedagógica nela apresentada;

(7) adequação da estrutura editorial e do projeto gráfico aos objetivos didático-pedagógicos da obra;

(8) pertinência e adequação do conteúdo multimídia ao projeto pedagógico e ao texto impresso.

(BRASIL, 2013b, p. 39)

Em relação aos critérios de eliminação de cada área, observamos que na área de Linguagens, códigos e suas tecnologias, reforça-se a necessidade de um trabalho interdisciplinar entre as diversas disciplinas que a compõem: Língua Portuguesa, Língua Estrangeira Moderna (Inglês e Espanhol), Artes e Educação Física ${ }^{55}$. Assim, embora não esteja explicitado, é possível concluir que as obras que tratarem as disciplinas como objetos estanques, não relacionados com as demais linguagens, serão avaliadas como inadequadas e, portanto, serão excluídas do processo de aquisição.

\footnotetext{
${ }^{55}$ Essa orientação retoma, como mostramos anteriormente, o que foi estabelecido nas DCNEM (BRASIL, 1998, 2013a) em relação à importância da articulação entre as disciplinas e as áreas de conhecimento.
} 
(...) uma das perspectivas mais promissoras da organização em área de disciplinas como Língua Portuguesa, Língua Estrangeira Moderna, Arte e Educação Física, que compõem a área de LCT, é a abordagem interdisciplinar, tanto de temas e objetos de ensinoaprendizagem comuns à área quanto das disciplinas envolvidas. Sem eliminar o ponto de vista que evidencia as especificidades de cada componente curricular, essa perspectiva evita a especialização excessiva e artificial. E, ainda, favorece o desenvolvimento daquelas capacidades, ferramentas e procedimentos que, por se revelarem implicados em conhecimentos disciplinares os mais variados e diversos, colaboram para o desenvolvimento da autonomia relativa do aluno no processo de aprendizagem. É o que acontece com a proficiência em leitura e escrita, implicada não só em toda a área, mas também em todo o ensino-aprendizagem escolar. E o mesmo se pode dizer do domínio de diferentes formas de expressão, comunicação e interação.

(BRASIL, 2013b, p. 44)

Por fim, para os critérios eliminatórios ligadosao trabalho com Língua Portuguesa, o Edital apresenta um conjunto de determinações específicas que deve constar na obra, evidenciando que a exclusão será resultado do não cumprimento desses aspectos. Essas determinações aparecem separadas no documento de acordo com o eixo de ensino-aprendizagem - leitura, escrita, oralidade e conhecimentos linguísticos - e se referem ao tratamento didático proposto pela coleção.

Como o objetivo de trabalho interdisciplinar está presente em toda a proposta, orienta-se que os quatro eixos de ensino sejam correlacionados e que as diversas formas de linguagem (verbal e não verbal; oral e escrita) sejam trabalhadas em suas relações, nunca de forma isolada. Assim, ainda que apresentados separadamente no Edital, eles devem ser correlacionados no LDP.

É nesse tópico, também, que são detalhadasas observações do que deve constar no manual do professor: "explicitar a organização da obra, os objetivos pretendidos e a orientação teórico-metodológica assumida", bem como "sugerir propostas de articulação entre os eixos de ensino e atividades de abordagem interdisciplinar dos conteúdos". Neste manual deve constar, ainda, orientação bibliográfica que dê suporte ao trabalho do professor. (BRASIL, 2013b, p. 46.) 
Considerando nosso particular interesse com o estudo de gêneros orais, reproduzimos a seguir o que o Edital elenca como critérios fundamentais para o trabalho com o eixo da oralidade:

Assim como no ensino fundamental, as coleções didáticas de LP dirigidas para o ensino médio devem reservar à oralidade uma proposta de ensino-aprendizagem própria. Considerando as demandas dessa etapa de ensino e o perfil de seu alunado, as atividades devem:

- favorecer a reflexão sobre as diferenças e semelhanças que se estabelecem entre as modalidades oral e escrita, combatendo os preconceitos associados às variedades orais;

- explorar gêneros orais adequados a situações comunicativas diversificadas, particularmente os mais relevantes seja para a expressão pública de opinião, seja para o desenvolvimento da autonomia relativa nos estudos (entrevista, jornal falado, debate regrado, apresentação de trabalho, seminário, exposição oral etc.);

- desenvolver a capacidade de escuta atenta e compreensiva do aluno;

- orientar a construção do plano textual dos gêneros orais (critérios de seleção e hierarquização de informações, padrões de organização geral, recursos de coesão).

(BRASIL, 2013b, p. 45)

As orientações apresentadas nesses tópicos remetem à relevância de tratar das aproximações entre a linguagem oral e escrita, das especificidades do estilo próprio do discurso oral, em determinados gêneros, e da necessidade de compreendê-los no interior da atividade humana em que ele é produzido.

Desta forma, por terem sido aprovadas, as coleções selecionadas nesse trabalho respondem, ainda que minimamente, a esses critérios.

\subsubsection{Guia de livros didáticos: PNLD 2015ensino médio português ${ }^{56}$}

O guia do livro didático de Português do ensino médio, produzido pela equipe de especialistas responsável pela avaliação, é o produto final desse processo. Nele podem ser encontradas as resenhas dos livros aprovados, com quadros que dão destaque a qualidades ou lacunas da obra.

\footnotetext{
${ }^{56}$ Doravante, Guia.
} 
O objetivo é que os professores façam a leitura do documento para que tenham base para realizar a escolha da coleção que será adotada por eles no ano letivo subsequente. Espera-se que seja feita uma discussão acerca dos aspectos pedagógicos de uma determinada obra para verificar se ela atende às necessidades, interesses e especificidades da comunidade escolar.

Após esse processo e ao chegar em um consenso, os docentes devem indicar o título de uma obra como primeira opção e o de outra em segunda opção. A intenção é que haja uma flexibilização, pois, se a primeira escolha não puder ser atendida, o professor ainda teria a segunda alternativa respeitada.

No ano que precedeu a distribuição das obras (2014), os professores e equipe pedagógica das escolas públicas de todo o país receberam o Guia para leitura e, a partir dele, selecionaram os LDP's que seriam usados no triênio 20152017.

Oliveira, em pesquisa sobre os usos dos LDP's na prática docente, aponta para uma lacuna nesse processo. Ela constatou,em entrevista com professores, que esse objetivo de orientação do Guia às vezes perde-se, visto que "não há um tempo destinado a esse momento [à leitura e análise do documento] no calendário escolar, nem há acesso ao Guia de Livros Didáticos". (OLIVEIRA, 2013, p. 190. ênfase da autora). Além disso, o estudo da autora demonstrou que a presença de editoras, agindo diretamente junto aos professores da escola, acaba por favorecer uma escolha menos analítica da obra, conforme declara uma das professoras que participou da entrevista: "(...) a editora que apresentou e foi feita a escolha em cima dessa apresentação da editora". (loc. cit.)

Além da problemática acima apontada, algumas pesquisas evidenciam que, mesmo quando os professores têm a possibilidade de fazer uma escolha da obra, esta não é atendida, pois o governo encaminha, por vezes, obras diferentes das que foram selecionadas pelo docente. Essa realidade parece ter uma justificativa já prevista no Edital, em item que trata do processo de aquisição das obras:

10.2.3. Não havendo acordo entre as partes em relação ao preço, o FNDE poderá deixar de contratar as obras escolhidas em primeira opção e contratar as obras escolhidas em segunda opção, ou ainda, na eventualidade de um novo impasse, fazer a opção pela obra mais escolhida em cada região. 
Faz-se necessário ressaltar, que, apesar das dificuldades acima apontadas, consideramos que a inclusão do professor no processo de escolha do LDP não só é positiva, mas necessária, visto ser ele o primeiro a fazer uso da obra. Não é o caso, pois, de desacreditar na relevância do documento, considerando os problemas, mas, levando estes em conta, de rever estratégias para que a voz do professor seja realmente validada.

No que tange aos profissionais que fizeram parte desse processo de avaliação no âmbito do PNLD 2015, o Guia evidencia que colaboraram como avaliadores um grande número de pesquisadores de diversas universidades brasileiras, em sua maioria, públicas.

\title{
Tabela12 - Relação dos avaliadores do PNLD 2015
}

Avaliadores
Ana Maria Costa de Araújo Lima (UFPE)
Cristina Teixeira Vieira de Melo (UFPE)
Elisângela Santana dos Santos (UNEB)
Else Martins dos Santos (Faculdade de Sabará)
Elton Bruno Soares de Siqueira (UFPE)
Evaldo Balbino da Silva (UFMG)
Ewerton Ávila dos Anjos Luna (UFPE)
Gilberto Xavier da Silva (PUC-MINAS)
Gustavo Henrique da Silva Lima (UFPE)
Isaltina Maria de Azevedo Mello Gomes (UFPE)
José Herbertt Neves Florêncio (UFPE)
Julio César Fernandes Vila Nova (UFPE)
Julio Neves Pereira (UFBA)
Lícia Maria Freire Beltrão (UFBA)
Lilian Santana da Silva (IFBA)
Marcelo Chiaretto (UFMG)
Márcio Ricardo Coelho Muniz (UFBA)
Maria Aparecida Araújo e Silva (UNA-MG)
Maria Aparecida da Mata (PUC-MINAS)
Maria Flor de Maio Barbosa Benfica (PUC-MINAS)

Maria Neuma Mascarenhas Paes (UNEB) Maria Zélia Versiani Machado (UFMG) Marianne Carvalho B. Cavalcante (UFPB) Neila Maria Oliveira Santana (UNEB) Noemi Pereira de Santana (UFBA) Patrícia Ribeiro de Andrade (UNEB) Renata Pimentel Teixeira (UFPE) Roberto Alexandre do Carmo Said (UFMG) Sílvio Roberto dos Santos Oliveira (UNEB) Simone Bueno Borges da Silva (UFBA) Simone Souza de Assumpção (UFBA) Suzana Leite Cortez (UFPE) Vanir Consuelo Guimarães (UNI-BH) Williany Miranda da Silva (UFCG)

DelaineCafiero Bicalho (UFMG) Marcos Rogério Cordeiro Fernandes (UFMG)

Avaliador especialista - livros digitais Roxane Helena Rodrigues Rojo (Unicamp)

Fonte: BRASIL, 2014

\begin{abstract}
Além dos 37 professores $^{57}$ ligados diretamente à avaliação, o programa contou ainda com o suporte de mais 17 profissionais, entre consultores,
\end{abstract}

\footnotetext{
${ }^{57}$ A relação apresentada trata todos os avaliadores como "professores" (que são) e não dá destaque ao seu papel de pesquisadores, excluindo títulos acadêmicos como "mestre" ou "doutor", embora saibamos que todos eles sejam especialistas e estudiosos da área de Língua Portuguesa. Considerando que o Guia foi elaborado para ser lido por professores, essa estratégia de apagamento
} 
coordenadores, revisores, leitores críticos, analistas de recursos e pessoal de apoio técnico. Ao todo, portanto, foram 54 pessoas ligadas ao processo de avaliação das dez coleções aprovadas. A seguir apresentamos os demais especialistas responsáveis pela consolidação desse programa.

Tabela 13 - Relação da equipe responsável pelo PNLD 2015

\begin{tabular}{|c|c|}
\hline \multirow{3}{*}{$\frac{\text { Consultor técnico }}{\text { Egon de Oliveira Rangel (PUC-SP) }}$} & Apoio técnico \\
\hline & Jeanne Lott (UFMG) \\
\hline & Renata Angélica (UFMG) \\
\hline Coordenação institucional & Ana Paula Andrade Duarte (UFMG) \\
\hline Sandra Maria Gualberto Braga Bianchet (UFMG) & Augusto da Silva Costa (UFMG) \\
\hline Coordenação de área & Leitura crítica \\
\hline Regina Lúcia PéretDell Isola (UFMG) & Joelma Rezende Xavier (Cefet-MG) \\
\hline Coordenação de área - livros digitais & $\underline{\text { Revisão }}$ \\
\hline Adriana Gouvea Dutra Teixeira (UFMG) & Sandra Maria Gualberto Braga Bianchet (UFMG) \\
\hline Coordenação adjunta & Analistas de recursos \\
\hline Ana Maria de Carvalho Luz (UFBA) & Eloisa Helena Rodrigues Guimarães(Faculdade \\
\hline Elizabeth Marcuschi (UFPE) & Pedro Leopoldo) \\
\hline Maria da Graça da Costa Val (UFMG) & Márcio de Melo Araújo (UFT) \\
\hline & Nabil Araújo de Souza (UERJ) \\
\hline $\begin{array}{l}\text { Instituição resp } \\
\text { niversidade Fede }\end{array}$ & $\begin{array}{l}\text { ável pela avaliação } \\
\text { Minas Gerais (UFMG) }\end{array}$ \\
\hline
\end{tabular}

Fonte: BRASIL, 2014

Conforme afirmam Batista, Rojo e Zúñiga (2008), a seleção de profissionais especialistas, tanto na área do ensino, quanto na de pesquisas relacionadas à disciplina de Língua Portuguesa, advindos de diversas partes do país, visa a legitimar, como voz de autoridade, a avaliação empreendida no interior desse programa governamental.

Além disso, os autores evidenciam que o controle do currículo pelo Estado se dá não apenas no momento da avaliação - cujos critérios estão pautados tanto em uma orientação conceitual e política (a partir da seleção de conteúdos), quanto em uma orientação metodológica (a partir da transposição didática desses saberes) -, mas também no momento da escolha desses livros, visto que a seleção da obra

pode contribuir para uma maior aproximação entre a escola e a academia, ao menos no contexto dessa produção. 
deve ser feita ${ }^{58}$ pelos professores a partir de um Guia, instrumento básico definido pelo governo para divulgação, nas escolas, das obras aprovadas. (BATISTA, ROJO e ZÚÑIGA, 2008)

No que diz respeito à organização interna, o Guia está dividido em duas partes centrais. De um lado, apresenta um diálogo com o professor, buscando explicar a este como escolher o LDP e quais as concepções de Língua Portuguesa no contexto do ensino médio, além de trazer, de forma geral, uma breve apresentação das características das obras, considerando a coletânea e o trabalho com os quatro eixos de ensino: leitura, produção textual, oralidade e conhecimentos linguísticos. De outro, traz as resenhas de cada coleção, detalhadas pelos subtítulos: "visão geral", "quadro esquemático", "descrição da coleção", "análise da obra" e "em sala de aula".

A primeira parte traz três textos: a apresentação do guia, a contextualização das especificidades do ensino médio, seus princípios e objetivos e, por fim, um panorama geral do processo de avaliação e das especificidades das coleções aprovadas: organização, metodologia e tratamento dado a cada um dos eixos de ensino.

$\mathrm{Na}$ apresentação do Guia, observa-se um discurso de aproximação com os docentes com o uso da palavra "nós", presente tanto na pergunta colocada logo abaixo do título, quanto no primeiro parágrafo dessa seção.

Escolhendo um livro didático de Língua Portuguesa - o caminho das pedras

Que livro didático de português (LDP) queremos adotar para o ensino médio (EM), em nossa escola?

Nos próximos dias, todos nós, educadores e educadoras das redes públicas, estaremos empenhados em contribuir 0 mais criteriosamente possível para elaborar uma boa resposta para essa pergunta. (...).

(BRASIL, 2014, p. 7. Ênfase nossa.)

\footnotetext{
${ }^{58}$ Apesar de já termos apontado a problemática que envolve essa escolha, não há como negar que o Guia tem esse caráter norteador e, portanto, o uso do verbo "dever", ainda que soe estranho se em contraste com a realidade, não deixa de ser pertinente em relação ao propósito do documento.
} 
Nesta parte também é apresentada a finalidade do guia: "colaborar para que nossas escolas promovam uma escolha qualificada do LDP, ou seja, uma escolha motivada por um processo de discussão o mais amplo e criterioso possível." (BRASIL, 2014, p. 7. Ênfase dos autores).

O segundo texto da primeira parte tem como título "Língua Portuguesa no contexto do ensino médio" e está dividido em: (a) Ensinar português no EM; (b) ensino médio, ENEM e vestibulares: um desafio a vencer; (c) Princípios e objetivos gerais para a disciplina de LP no EM.

Em "As coleções resenhadas neste guia", último texto da primeira parte, são apresentados subtópicos que evidenciam uma recuperação macroestrutural das coleções aprovadas: (1) a organização geral das coleções; (2) o movimento metodológico; (3) patamares de qualidade, este último com seis subitens: (a) coletâneas, (b) leitura, (c) produção escrita, (d) linguagem oral, (e) conhecimentos linguísticos, (f) objetos de ensino digitais. As informações presentes nesses tópicos são significativas para contribuir para o processo de escolha da obra didática.

Na segunda parte do Guiahá cinco subtítulos para organizar as informações sobre a obra.

Em "visão geral", evidencia-se a organização da coleção: quantidade de volumes, organização interna da obra (divisão por unidades / capítulos), além de apresentar, brevemente, o tratamento didático de cada eixo de ensino: leitura, literatura, produção de texto, oralidade e conhecimentos linguísticos.

No quadro-esquemático, são apresentados os pontos fortes, fracos e de destaque da obra, com indicação da divisão de tempo didático pertinente para que o LDP seja usado pelo docente e, ainda, com um breve comentário sobre o que traz o manual do professor.

Em seguida, em "descrição da coleção", a organização interna dos volumes é destacada, evidenciando minúcias quanto às quantidades de unidades e/ou capítulos e as seções internas que são relativamente fixas em cada obra. 
Um maior aprofundamento sobre como é realizado o trabalho com cada eixo de ensino acontece em "análise da obra". É neste momento que o leitor tem acesso às visões do resenhista quanto aos aspectos positivos e negativos da coleção.

Por fim, para encerrar a resenha, são apresentadas, no item "em sala de aula" indicações de fragilidades da obra que precisarão ser supridas pelo professor no decorrer de sua ação prática.

Com essa estrutura, observa-se que o documento procura trazer, na primeira parte, um direcionamento teórico-metodológico que facilite a compreensão das resenhas, as quais são apresentadas na segunda parte.

Visualmente, os títulos no interior do Guia estão marcados com cor vermelha e, ao longo do texto estão negritadas palavras como leitura, literatura, produção de textos escritos ${ }^{59}$, oralidade ${ }^{60}$, conhecimentos linguísticos, OEDs e manual do professor, sinalizando a atenção do leitor para os eixos de ensino e materiais que acompanham o livro do aluno. Na primeira parte, além destas, há outras palavras em negrito, como coletânea, letramento, formação do leitor, leitura proficiente, proficiência em escrita, entre outras. Esse recurso verbo-visual orienta o leitor para a localização de uma palavra-chave que seja de seu interesse, o que propicia uma leitura não-linear do documento.

Outro recurso verbo-visual significativo é o quadro-esquemático, mencionado anteriormente, que facilita o reconhecimento imediato de aspectos destacados pelo resenhista. Apresentamos dois exemplares deles, os quais se referem, respectivamente, às coleçõesNovas Palavras(AMARAL et al, 2013d) ePortuguês linguagens (CEREJA; MAGALHÃES, 2013d) ${ }^{61}$.

\footnotetext{
${ }^{59}$ Foram usadas também outras terminologias como "produção escrita", "produção de textos", "produção textual".

${ }^{60}$ Variações como "produção oral" e "produção de texto oral", embora com menor frequência, também foram utilizadas.

${ }^{61}$ Estas foram as duas coleções mais adquiridas pelo governo para envio às escolas em 2015 e serão, posteriormente, analisadas nesse trabalho.
} 
Figura 6 - Quadro esquemático de avaliação das coleções do PNLD 2015

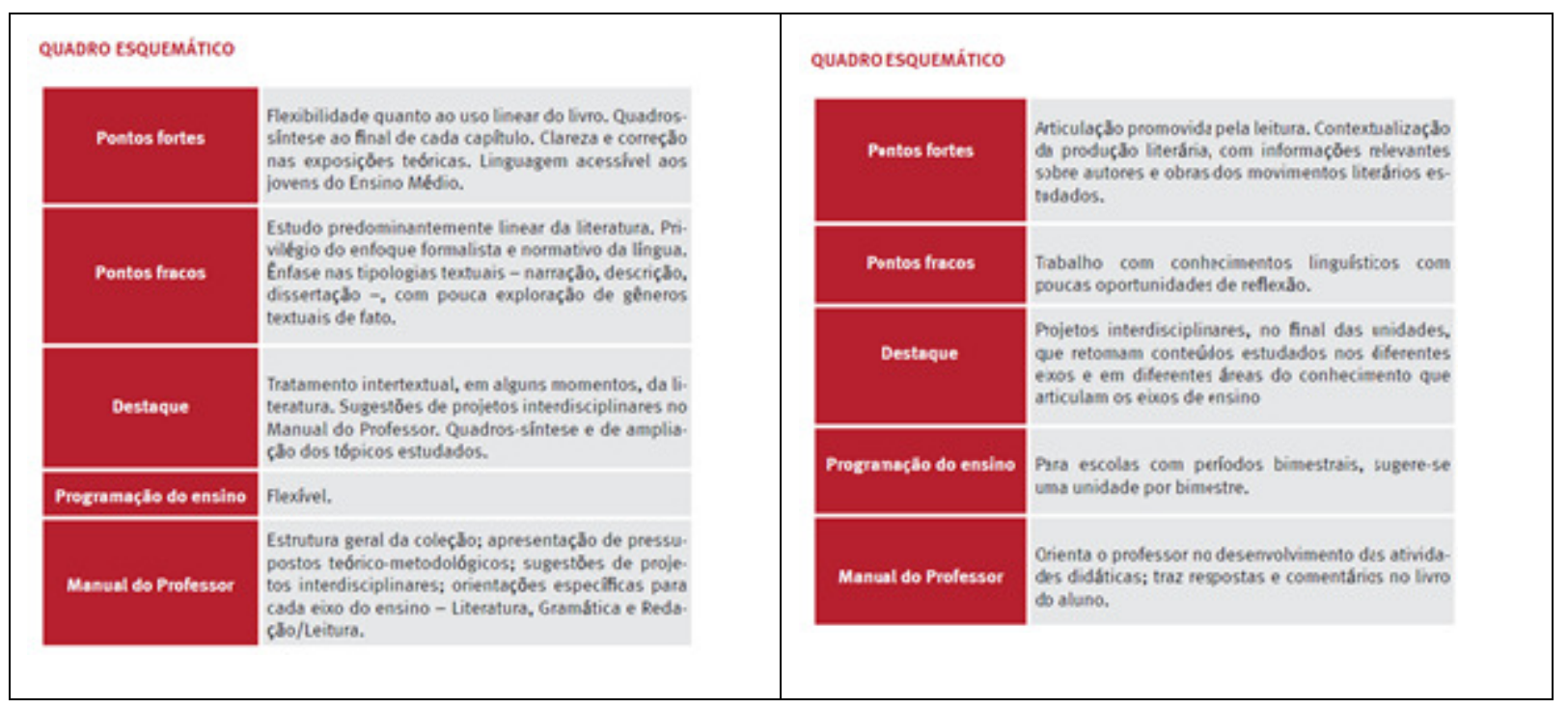

Fonte: BRASIL, 2014, p. 45 e 55.

Essa apresentação visual permite que, ainda que não haja tempo para uma leitura detalhada de todo o Guia, o professor consiga compreender minimamente os aspectos centrais que envolvem a coleção.

Concordamos com Oliveira (2013) ao mencionar que esse documento, apesar de sua relevância, não deveria ser o único instrumento para a escolha do LDP. O melhor seria que o professor tivesse acesso a todas as obras, para que pudesse apreender melhor as possibilidades de trabalho. Na impossibilidade disso, acreditamos que se o Guia trouxesse ao menos o sumário de cada coleção, o professor teria mais um instrumento para conseguir compreender a forma de organização de cada obra, o que seria significativo.

Após as duas partes centrais já comentadas, o Guia apresenta dois anexos: o primeiro refere-se aos princípios e critérios de avaliação, presentes no Edital do PNLD 2015, evidenciando os critérios eliminatórios comuns a todas as áreas e os específicos da área Linguagens, códigos e suas tecnologias; o segundo evidencia as questões norteadoras respondidas pelos avaliadores para analisar cada eixo de ensino da obra, bem como o manual do professor.

O objetivo dos anexos parece ser dar ao professor ciência tanto do documento norteador para a inscrição das obras - o Edital - quanto dos critérios utilizados pelos pareceristas para realizar essa avaliação. 
O anexo 1traz a reprodução exata de dois tópicos do anexo 3 do Edital(BRASIL, 2013b, p. 39 a 46). Embora tenham sido omitidas as numerações indicativas de sequencialidade presentes no Edital, todos os títulos e subtítulos, bem como o conteúdo a eles relacionado, foi mantido no Guia. Seguem os títulos das partes presentes nos dois documentos ${ }^{62}$ :

\section{Critérios de avaliação}

2.1. Critérios eliminatórios comuns a todas as áreas

2.1.1. Respeito à legislação, às diretrizes e às normas oficiais relativas ao ensino médio.

2.1.2. Observância de princípios éticos e democráticos necessários à construção da cidadania e ao convívio social republicano.

2.1.3. Coerência e adequação da abordagem teórico-metodológica assumida pela obra no que diz respeito à proposta didáticopedagógica explicitada e aos objetivos visados.

2.1.4. Respeito à perspectiva interdisciplinar na apresentação e abordagem dos conteúdos.

2.1.5. Correção e atualização dos conceitos, informações e procedimentos.

2.1.6. Observância das características e finalidades específicas do manual do professor e adequação da obra à linha pedagógica nela apresentada.

2.1.7. Adequação da estrutura editorial e do projeto gráfico aos objetivos didático-pedagógicos da obra.

2.1.8. Pertinência e adequação dos recursos multimídia ao projeto pedagógico e ao texto impresso.

3. Critérios eliminatórios específicos das áreas

3.1. Linguagens códigos e suas tecnologias

3.1.1. Princípios e objetivos gerais para a disciplina Língua Portuguesa no ensino médio.

3.1.2. Critérios eliminatórios específicos para o componente curricular Língua Portuguesa

(BRASIL, 2013b, p. 39-46; BRASIL, 2014, p. 82-92)

O anexo 2do Guiaapresenta o conjunto de questões que serviram de base para uma análise qualitativa da obra em diversos aspectos, sejam metodológicos, sejam os relativos à correção e adequação de conceitos ou imagens e, ainda, os referentes ao respeito à legislação.

Cada uma das questões apresentadas, no interior de cada tópico permite ao professor compreender o que era esperado como critério de qualidade para cada um dos tópicos avaliados. Como as respostas eram binárias (sim / não), é possível inferir que sempre que uma questão fosse respondida de forma positiva, o critério a

${ }^{62}$ Embora no Guia a numeração apresentada na citação não esteja presente, optamos por mantê-la aqui para que fique clara a diferença entre os dois documentos: no Edital os números aparecem, no guia eles foram omitidos. 
ser avaliado era bom. Assim, quanto maior o número de "sins", maior seria a qualidade da coleção.

Tomemos como exemplo perguntas do tipo (1) "Os textos são autênticos?" ou (2) "Os temas selecionados e os pontos de vista a partir dos quais são abordados contemplam a heterogeneidade sociocultural brasileira, quanto à faixa etária, etnia, gênero, classe social, região, entre outros?" (BRASIL, 2014, p. 93). É possível inferir, a partir delas, que textos autênticos e que exploram diversidade temática são esperados no interior da coleção. É nesse sentido que entendemos que o acesso a essas questões serve não apenas para a compreensão do processo de avaliação das coleções em si, mas tem também um caráter formativo, visto que o professor passa a compreender o que é esperado em matéria de ensino.

Para facilitar a compreensão da estrutura geral do anexo 2 do Guia, elaboramos a síntese a seguir.

\section{Tabela 14 - Síntese do anexo 2 do Guia do PNLD 2015}

Abordagem teórico-metodológica assumida pela coleção

O ensino de leitura

$\checkmark$ Coletânea de textos

$\checkmark$ As atividades

Produção de texto escrito

$\checkmark$ As atividades

Conhecimentos linguísticos

$\checkmark$ As atividades

* Adequação da coleção à linha pedagógica declarada

$\rightarrow$ Manual do professor

* Correção e atualização de conceitos, informações e procedimentos

* Respeito à legislação, às diretrizes e às normas oficiais relativas ao ensino médio e observância de princípios éticos e democráticos necessários à construção da cidadania e ao convívio social

* Adequação da estrutura editorial e do projeto gráfico aos objetivos didático-pedagógicos da coleção

Fonte: BRASIL, 2014, p. 93-102.

No que tange à avaliação da oralidade, que é de nosso particular interesse nessa pesquisa, o anexo 2 indica uma questão norteadoras para a análise das obras, seguida por oito perguntas que parecem especificar o que foi proposto na primeira: 
Oralidade

As atividades propostas - no material impresso e/ou nos OEDs colaboram significativamente para o desenvolvimento da linguagem oral do aluno?

$\rightarrow$ Exploram gêneros orais adequados a situações comunicativas diversificadas (entrevista, jornal falado, apresentação de trabalho, debate etc.) na produção?

$\rightarrow$ Estimulam o aluno a desenvolver a capacidade de escuta atenta e compreensiva?

$\rightarrow$ Exploram as relações entre as modalidades oral e escrita na língua em diferentes práticas sociais e em diferentes gêneros?

$\rightarrow$ Orientam a construção do plano textual dos gêneros orais (critérios de seleção e hierarquização de informações, padrões de organização geral, recursos de coesão)?

$\rightarrow$ Discutem e orientam a escolha do registro de linguagem adequado à situação (prosódia, recursos de coesão, seleção vocabular, recursos morfossintáticos etc.)?

$\rightarrow$ São isentas de preconceito associados às variedades orais?

$\rightarrow$ Orientam o uso de recursos audiovisuais como auxiliares à produção oral (cartaz, painel, projetor, entre outros)?

$\rightarrow$ As atividades dos OEDs contribuem para o ensino-aprendizagem do eixo da oralidade?

(BRASIL, 2014, p. 98-99)

Com base nessas perguntas é possível perceber que o Guia estabelece quepara desenvolver a linguagem oral o aluno deve conhecer / explorar: (1) gêneros orais; (2) capacidade de escuta; (3) relações das modalidades oral e escrita; (4) plano textual dos gêneros orais; (5) registro de linguagem adequado à situação; (6) variedades orais; (7) recursos audiovisuais para a produção oral.

Percebe-se, a partir desses aspectos, um diálogo tanto com as DCEM, quanto com as teorias da análise da conversação, linguística textual e ciência da linguagem (teoria bakhtiniana). O professor tem, assim, um direcionamento claro dos aspectos mais relevantes para o trabalho no eixo da oralidade.

Considerando oque foi apresentado nesse capítulo (especificidades dos alunos do ensino médio, documentos que orientam esse nível de escolarização e, por fim, os direcionamentos propostos no Edital e, como resultado, no Guia) que entendemos o espaço dos LDP-EM aprovados no PNLD 2015.

Os enunciados presentes nesses livros didáticos dialogam comessas vozes e evidenciam a tensão no interior da esfera escolar: respondem aos documentos oficiais que norteiam o ensino de português, atendem às exigências do Edital(porque 
precisam ser aprovados pelo MEC), consideram a visão do professor (que é quem escolhe a obra) e também o perfil pressuposto do aluno de ensino médio.

Pela relevância que o programa assume em nível nacional, justificamos a escolha das coleções didáticas selecionadas para nossa análise, sobre as quais trataremos em capítulo posterior.

Por hora, apresentaremos os caminhos metodológicos de nossa pesquisa. 


\section{CAPÍTULO 4}

\section{PERSPECTIVA TEÓRICO-METODOLÓGICA}

A coisa, ao permanecer coisa, pode influenciar apenas as próprias coisas; para influir sobre os indivíduos ela deve revelar seu potencial de sentidos, isto é, deve incorporar-se ao eventual contexto de palavras e sentidos.

(BAKHTIN, 1979/2011, p. 404)

A análise de qualquer objeto de investigação inicia-se pelo conhecimento desse objeto e, mais ainda, pelo reconhecimento do percurso empreendido para observá-lo.

Neste capítulo, apresentamos nosso corpus de pesquisa - quatro coleções de ensino médio aprovadas no PNLD 2015 -, bem como esclarecemos o nosso recorte de estudo: as atividades de debate presentesnos volumes selecionados. Uma retomada teórica desse gênero também é realizada para melhor compreensão de sua constituição e funcionamento.

Apresentamos, assim, a perspectiva teórico-metodológica adotada nesse estudo e uma descrição das coleções, bem como, elencamos os critérios que guiarão nosso olhar para a análise. 


\subsection{Delimitação da pesquisa}

O interesse por estudar livros didáticos de português ocorreu por duas razões: atuação na área, como consultora e autora de LDP, e atuação como professora em curso de licenciatura em Letras.

A definição pelo nível de ensino se deu após um cuidadoso levantamento bibliográfico que apontou poucos estudos em torno do livro didático de português de ensino médio. Quanto à escolha do eixo da oralidade, havia, até então, um menor número de trabalhos que traziam essa abordagem em manuais didáticos do período final da educação básica, o que nos instigou a tratar do assunto.

Definido o primeiro recorte - o estudo da oralidade em livros didáticos de ensino médio -, uma nova questão surgiu: investigar obras voltadas para as escolas públicas ou para as particulares? ${ }^{63}$

A segunda delimitação - o estudo de livros didáticos utilizados na rede pública de ensino - foi feita por haver um programa já consolidado de avaliação de livros didáticos adquiridos pelo governo para uso nas escolas públicas: o Programa Nacional do Livro Didático, que, no ensino médio, iniciou-se em $2003^{64}$, com a publicação do primeiro edital de convocação, como mostramos no capítulo anterior. O recorte foi então estabelecido: trabalhar com as dez coleções ${ }^{65}$ aprovadas no PNLD 2015, o mais recente ${ }^{66}$ na ocasião em que essa tese foi iniciada.

Os estudos bibliográficos ao longo do processo da pesquisa e a primeira análise das dez coleções aprovadas no PNLD 2015 evidenciaram que o eixo da oralidade era amplo, pois abarcava uma variedade muito grande de gêneros e

\footnotetext{
${ }^{63}$ Obras voltadas para as escolas particulares são chamadas internamente nas editoras de "versão mercado" e as que têm foco na escola pública são tratadas por "versão governo". Como os objetivos divergem, a produção dos dois tipos de obra gera resultados diferentes na composição final do livro didático.

${ }^{64} \mathrm{Na}$ disciplina de Língua Portuguesa, é no PNLEM 2006 (edital de 2004) que a distribuição das obras didáticas é feita para todo o país. Destacamos, porém, que a distribuição integral de LDP-EM de todas as disciplinas para o território nacional só ocorreu a partir de 2009 , ano em que as obras aprovadas no PNLEM 2009 chegaram às escolas. Este é o ano, portanto, em que esse programa se consolida.

${ }^{65} \mathrm{O}$ anexo 1 apresenta o conjunto das coleções do PNLD 2015.

${ }^{66}$ A divulgação das obras aprovadas no PNLD 2015 ocorreu em 2014. Após esse PNLD, apenas no ano de 2017 (em curso) saiu uma nova lista de livros didáticos (PNLD 2018) para a serem utilizados no ano subsequente.
} 
incluía discussões a respeito de variação linguística na relação entre a fala e a escrita, bem como aspectos ligados à especificidade do oral relacionados com a interação face a face.

Levando em conta o escopo teórico de nossa tese, cujas bases fundam-se na teoria dialógica do discurso - realizamos uma segunda leitura das coleções, com foco nas propostas de gêneros orais. Naquela ocasião, optamos também por fazer um recorte em relação à quantidade de obras a serem analisadas. Das dez coleções, selecionamos quatro, as quais, segundo dados do Fundo Nacional do Desenvolvimento da Educação (FNDE), foram as mais distribuídas ${ }^{67}$ nas escolas públicas.

O último recorte ocorreu após observar o levantamento dos principais gêneros orais nas quatro coleções ${ }^{68}$. O debate foi tomado como objeto de ensino em todas as coleções estudadas. Sua escolha deveu-se, portanto, a sua presença em toda a coletânea.

\section{Figura 7 - Delimitação da pesquisa}

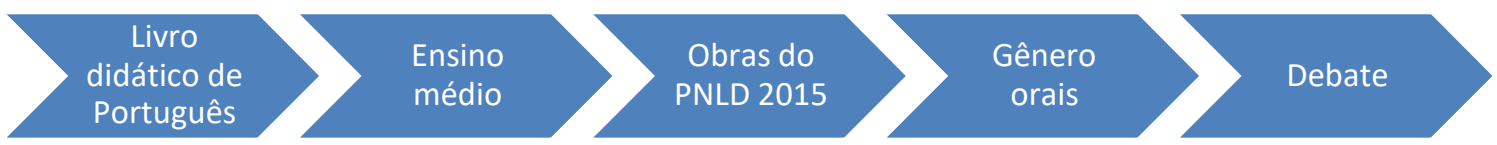

Fonte: Elaborado pela autora.

O percurso de delimitação desta tese foi, assim, concretizado.

\subsection{Caracterização do gênero debate}

Embora Bakhtin não tenha proposto uma definição formal de gêneros, inclusive por reconhecê-los como "relativamente estáveis" e, justamente por isso, ser bastante complexa qualquer definição, para fins de didatização essa prática tornouse recorrente, uma vez que, para o processo de ensino-aprendizagem, uma sistematização do conhecimento é normalmente esperada.

\footnotetext{
${ }^{67} \mathrm{O}$ anexo 2 apresenta a relação das obras e a quantidade adquirida pelo governo. Este documento pode ser encontrado no site do FNDE disponível em <www.fnde.gov.br/programas/livro-didatico/livrodidatico-dados-estatisticos>. Acesso em 05/03/2016.

${ }^{68}$ Os anexos 3 a 6 (e suas subdivisões) evidenciam o resultado desse estudo.
} 
O principal conceito da teoria dialógica do discurso que dá base inicial a essa discussão nos livros didáticos de português é a própria noção de gêneros do discurso, especialmente no que se refere aos elementos que o compõem: forma composicional, conteúdo temático e estilo.

No que tange ao conteúdo temático, podemos caracterizá-lo como um texto em que duas ou mais pessoas emitem opiniões divergentes para a defesa de um ponto de vista, em geral tendo como base um tema polêmico. Nesse diálogo entre vozes sociais discordantes, cada participante busca argumentos para validar seu ponto de vista e para criticar a posição contrária.

O estilo está ligado às escolhas linguísticas empreendidas pelo sujeito para a defesa de sua opinião no momento da interação. Alguns aspectos recorrentes no gênero debate estão ligados ao uso de operadores lógico-argumentativos (como conjunções e advérbios) ou modalizadores, visto ser a argumentação uma estratégia discursiva predominante nesse gênero.

Embora o debate seja, normalmente, produzido oralmente ${ }^{69}$, a relação que estabelece com a escrita é muito forte, uma vez que os participantes da interação, no momento de preparação de suas discussões, realizam leituras diversas e fazem anotações que dão suporte, posteriormente, às suas falas. Assim, o estilo empregado tende a ser mais formal.

É importante destacar, no entanto, que o uso da linguagem no interior do evento deve considerar o sujeito social que enuncia e o próprio contexto (imediato e histórico) em que esse enunciado ocorre. Dessa forma, a maneira singular com que o autor utiliza a linguagem deve ser levada em conta no processo de ensino, inclusive porque essas escolhas revelam uma tomada de posição e uma avaliação empreendida pelo sujeito.

Em relação à forma composicional do gênero debate, o discurso se organiza pela troca de turnos, ocasião em que quando um interlocutor toma a palavra, o outro deve escutar sem interrompê-lo. Para isso, a noção de polidez é reguladora da ação, pois, sem ela, não é possível que se construa um diálogo produtivo, de real troca

${ }^{69}$ É importante considerar que é bastante comum atualmente o debate escrito nas redes sociais. Embora esse não seja o enfoque desta pesquisa, entendemos que um estudo mais pontual sobre como ele se realiza por escrito (aproximações e distanciamentos) seria significativo para uma ampliação da caracterização desse gênero. 
entre os interlocutores. Pode-se dizer, assim, que o turno é negociado, visando aos interesses construídos no evento. Nesse sentido, o silêncio também faz parte da forma composicional do gênero, uma vez que ele indica que o outro participante já pode fazer uso da palavra.

Considerando os estudos da teoria dialógica do discurso, podemos entender que o silêncio indica uma tomada de posição do sujeito, uma vez que a escolha por se calar também revela um "dizer", como ocorre, exemplo, quando alguém quer findar um debate improdutivo, evidenciando assim um descontentamento. O silêncio tem, portanto, um teor valorativo.

O conceito de esfera de comunicação social é igualmente relevante para a caracterização do gênero debate, visto que é no campo de uso da língua que se pode evidenciar tanto a situação concreta de produção (relação dos interlocutores e a finalidade do dizer), como o diálogo efetivo que essa situação imediata constrói com o contexto sócio-histórico mais amplo.

No que tange ao contexto imediato, o debate efetiva-se pela troca de papeis sociais entre os interlocutores: ora defendem seu ponto de vista, ora replicam o argumento adversário do outro participante (no papel de debatedor). Em debates públicos, é comum alguns interlocutores ocuparem o lugar social de ouvinte, ocasião em que interagem de forma diversa com os debatedores, pois, apesar de não fazerem uso da palavra, podem se manifestar com palmas, vaias, silenciamentos ou expressões faciais reveladoras de um "dizer".

A presença do mediador é mais comum em debates regrados, como os divulgados em programas de TV, por exemplo. Ele também participa na organização do debate, exercendo um papel fundamental para designar não só quem deve tomar a palavra, mas também quando deve se calar. Em debates cotidianos, porém, é menos comum essa participação.

No contexto sócio-histórico, é importante destacar que a realização do debate é um reflexo de sociedades democráticas, visto que exerce um importante papel para o exercício da cidadania. Assim, em um tempo histórico em que não se permite uma tomada de posição, como ocorreu na época da ditadura em nosso país, esse gênero não tem possibilidade de existência. Essa realidade não é, porém, algo do passado. Na esfera do trabalho, por exemplo, os debates só se farão presentes 
em instituições que acreditem na necessidade da interação e da troca de opiniões. Quando isso não for uma verdade, também não haverá espaço para a presença do debate.

Para fins de didatização, é importante citar os trabalhos dos pesquisadores genebrinos, que apresentam uma caracterização do gênero considerando suas possibilidades para o ensino.

Ao tratar sobre o debate, Dolz, Schneuwly e De Pietro (2004) afirmam que o "debate televisivo" é, em geral, tomado como modelo exemplar do que ele representa e de como se organiza. A problemática dessa associação é a de que se pode passar a falsa ideia de que nesse gênero há apenas um "afrontamento" (op. cit., p. 249).

A fim de estabelecer um delineamento sobre o que se pretende explorar na escola, os autores genebrinos apontam três formas de debate para o trabalho escolar: (1) o debate de opinião de fundo controverso; (2) o debate deliberativo; (3) o debate para resolução de problemas.

No primeiro caso - debate de opinião de fundo controverso -, o enfoque recai na defesa de um posicionamento pessoal a partir de um tema polêmico, cujo objetivo seria tanto influenciar a posição do outro, quanto de repensar as suas próprias crenças acerca de algum assunto. Para os autores, "por meio de confrontações e dos deslocamentos de sentido que permite" essa forma de debate serviria "não somente [para] compreender um assunto controverso por suas diferentes facetas, mas também [para] forjar uma opinião ou de transformá-la". (DOLZ, SCHNEUWLY, DE PIETRO, 2004, p. 250). Um exemplo desse tipo de debate seria "Vantagens e desvantagens do uso de bicicletas".

No segundo caso - debate deliberativo -, a ação está voltada para a tomada de decisão, ou seja, da discussão proposta é necessário que haja uma escolha única comum a todo o grupo. A estratégia de argumentação dos participantes da interação está voltada para a explicação de um dado ponto de vista e negociação, com os demais colegas, para chegar a um senso comum. Esse tipo de debate permite "traçar soluções originais, que integram posições anteriormente opostas". (DOLZ, SCHNEUWLY, DE PIETRO, 2004, p. 250). Para exemplificar, os autores apontam questão do tipo "Aonde ir na viagem de formatura?" 
No terceiro caso - debate para resolução de problemas -, o foco está na construção coletiva de uma solução para um dado problema, em geral ligado a um não-saber ou a um saber parcial. É a proposição de uma discussão sobre um determinado tema do conhecimento que tem como objetivo "aumentar as capacidades dos alunos para gerir a busca de soluções, formulando as suas e escutando as dos outros, a fim de tirar partido do conjunto de saberes distribuídos no grupo de debatedores." (DOLZ, SCHNEUWLY, DE PIETRO, 2004, p. 250). O exemplo trazido pelos pesquisadores diz respeito a propostas como: "Por que acontece o eclipse da lua?"

Nascimento (2015, p. 198), ao discutir sobre os trabalhos desses pesquisadores, afirma que eles "se baseiam numa concepção de gêneros como construtos culturais criados pelas sociedades ao longo da história humana".

Dessa forma, entendemos que a contribuição dos pesquisadores genebrinos vai ao encontro de uma visão de gênero ligada à prática social, e, no caso deles, especialmente voltado para a transposição do debate para a esfera escolar.

É nesse sentido, como prática social, que a autora (NASCIMENTO, 2015) vai propor uma reflexão a respeito do gênero "debate oral coletivo" em atividades didáticas de uma sala de aula.

Tomando como base os estudos dos pesquisadores genebrinos (DOLZ, SCHNEUWLY, DE PIETRO, 2004), Nascimento observa o papel do professor no momento do debate, apontando a relevância dele na condução da proposta:

No debate oral coletivo em sala de aula há elementos a serem trabalhados pelo professor que podem ajudar os alunos a identificar uma controvérsia, a evitar os impasses que podem tornar o debate um palco de interações conflituosas ou, ao contrário, um debate morno e sem motivação. Para isso, a audição de debates em vídeo propicia a familiaridade com aquela prática social bem como observações e análises do comportamento discursivo dos participantes. Esse é o momento em que o professor pode definir com os alunos os princípios orientadores para a ação de cada um no debate coletivo.

(NASCIMENTO, 2015, p. 202-203)

A autora ainda enfatiza outras posturas necessárias ao docente, desde um distanciamento no momento de interação entre os alunos e o cuidado para não 
interrompê-los, até a resistência para não impor sua própria opinião como verdade maior.

No que tange à relação entre fala e escrita, entendemos que o gênero debate, apesar de ocorrer em situação oral de interação, permite a aproximação com textos materializados que podem servir de base para a discussão, seja na forma de leituras prévias, seja por registros anotados para dar sustentação à fala. Além disso, no decorrer do debate, é possível que os interlocutores envolvidos façam anotações relativas ao que foi dito para sustentar sua argumentação posterior. Enfim, há uma inter-relação entre essas duas modalidades que também precisa ser considerada no processo de ensino.

Os estudos da teoria dialógica do discurso também podem servir de aporte para a reflexão sobre o debate em sala de aula se considerarmos a retomada do discurso do outro - paráfrases, por exemplo - como palavra "internamente persuasiva" (BAKHTIN, 1930-36/2015, p. 136), a qual não apenas serve de base para a argumentação, mas evidencia uma tomada de posição, uma apreciação valorativa, uma avaliação do dito no interior da situação comunicativa.

A relação entre a palavra internamente persuasiva e a palavra autoritária para compreendermos as atividades do gênero debate no interior do LDP-EM é bastante significativa.

Segundo Bakhtin (1930-36/2015, p. 132), "no discurso do dia a dia de qualquer pessoa que tem vida social, ao menos metade de todas as palavras que ela pronunciou são palavras alheias". Como essa assimilação não ocorre de maneira mecânica, a incorporação do discurso do outro no próprio discurso pode ocorrer de duas formas: como um discurso autoritário ou como um internamente persuasivo.

O primeiro é monológico, pois não permite questionamentos nem vacilações. São exemplos, o discurso religioso, governamental ou da moral. No discurso autoritário deve haver, por parte do sujeito, um reconhecimento incondicional, visto que ele é imposto, sem margens para a não aceitação.

O segundo - discurso internamente persuasivo - "é desprovido de autoritarismo, não é apoiado por nenhuma autoridade, amiúde carece de qualquer reconhecimento social" (1930-36/2015, p. 136). Nesse sentido, é um discurso multivocal, pois nele se entrecruzam vozes que dialogam entre si. 
A leitura desses dois conceitos podem nos ajudar a perceber de que forma as atividades do LDP-EM são apresentadas aos alunos: como discurso autoritário ou como internamente persuasivo. Além disso, no diálogo com os documentos oficiais Edital e OCEM - essas duas noções nos darão base para perceber como o LDP-EM incorpora o discurso governamental.

Apesar de não haver uma conceituação explícita do gênero debate nas obras do Círculo, a caracterização do discurso retórico é significativa, pois revela a importância da palavra alheia na construção de um posicionamento:

Os gêneros retóricos conhecem as formas mais diversas de transmissão do discurso do outro, e ademais essas formas, na maioria dos casos, são intensamente dialogadas. A retórica usa amplamente intensas reacentuações das palavras transmitidas (...). Para estudar as diferentes formas de transmissão do discurso do outro, os diferentes meios de sua enformação e molduragem, os gêneros retóricos são um material sumamente promissor.

(BAKHTIN, 1930-36/2015, p. 150)

O entrecruzamento de vozes no discurso, dessa forma, é um dado fundamental para o estudo do debate.

Assim, mais que tratar de aspectos interacionais (posição dos interlocutores, papel desempenhado por cada um) e linguístico-discursivos (estratégias argumentativas para defesa de um ponto de vista), acreditamos que a prática didática com esse gênero deve levar o aluno a perceber como o sujeito pode reagir dialogicamente, colocando sua voz autoral no discurso e assumindo sua responsabilidade no interior do ato.

\subsection{Constituição do Corpus}

Ocorpus de análise são as propostas do gênero debate em quatro coleções $^{70}$ aprovadas pelo PNLD 2015 e mais distribuídas nas escolas públicas de todo país, considerando o volume de compras (BRASIL, 2016).

\footnotetext{
${ }^{70}$ Quando houver necessidade de fazer referência às quatro obras selecionadas, utilizaremos o termo "coletânea".
} 


\section{Tabela15 - Coleções ${ }^{71}$ que compõem o corpus da pesquisa}

\begin{tabular}{|c|c|c|c|}
\hline Capa & Título da obra & AUTORES & $\begin{array}{l}\text { Edição / local / } \\
\text { editora / ano }\end{array}$ \\
\hline$=8$ & $\begin{array}{l}\text { PORTUGUÊS } \\
\text { LINGUAGENS }^{72}\end{array}$ & $\begin{array}{l}\text { William Roberto Cereja } \\
\text { Thereza A. Cochar Magalhães }\end{array}$ & $\begin{array}{l}\text { 9a edição. } \\
\text { São Paulo: } \\
\text { Saraiva, } 2013\end{array}$ \\
\hline 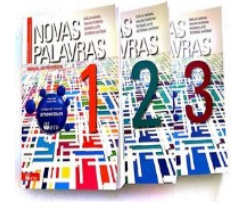 & $\begin{array}{l}\text { NOVAS } \\
\text { PALAVRAS }^{73}\end{array}$ & $\begin{array}{l}\text { Emília Amaral } \\
\text { Mauro Ferreira } \\
\text { Ricardo Leite } \\
\text { Severino Antônio }\end{array}$ & $\begin{array}{l}2^{\mathrm{a}} \text { edição. } \\
\text { São Paulo: } \\
\text { FTD, } 2013 .\end{array}$ \\
\hline & $\begin{array}{l}\text { PORTUGUÊS } \\
\text { CONTEXTO, } \\
\text { INTERLOCUÇÃO } \\
\text { E SENTIDO }^{74}\end{array}$ & $\begin{array}{l}\text { Maria Luiza M. Abaurre } \\
\text { Maria Bernadete M. Abaurre } \\
\text { Marcela Pontara }\end{array}$ & $\begin{array}{l}2^{2} \text { edição. } \\
\text { São Paulo: } \\
\text { Moderna, } 2013 .\end{array}$ \\
\hline 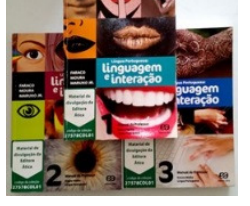 & $\begin{array}{l}\text { LÍNGUA } \\
\text { PORTUGUESA: } \\
\text { LINGUAGEM E } \\
\text { INTERAÇÃ }{ }^{75}\end{array}$ & $\begin{array}{l}\text { Carlos Emílio Faraco } \\
\text { Francisco Marto de Moura } \\
\text { José Hamilton Maruxo Júnior }\end{array}$ & $\begin{array}{l}2^{a} \text { edição. } \\
\text { São Paulo: } \\
\text { Ática, } 2013 .\end{array}$ \\
\hline
\end{tabular}

Fonte: Elaborado pela autora.

Uma vez que o Programa Nacional do Livro Didático já realiza a seleção de obrascom critérios definidos, e que estas são adotadas em toda rede pública de ensino brasileira, consideramos que o estudo desta coletânea pode nos dar a dimensão do que se propõe sobre o ensino do gênero debate em âmbito nacional.

As coleções selecionadas referem-se ao livro destinado ao docente e possuem, portanto, tanto as atividades propostas no livro do aluno (L.A.) e suas respostas, quanto as orientações didáticas do manual do professor (M.P.). Essa escolha visa a facilitar uma leitura global sobre a orientação didática para a condução do ensino. Se tomássemos apenas o L.A. como objeto de estudo, perderíamos o diálogo proposto para o desenvolvimento da prática pedagógica, que geralmente é explicitado no M.P.

\footnotetext{
${ }^{71}$ Para fazer referência à coleção, estabelecemosum número e um código para cada uma, que são as primeiras letras do título da obra.

${ }_{73}^{72}$ Doravante, col.1-PL.

${ }^{73}$ Doravante, col.2-NP.

${ }^{74}$ Doravante, col.3-PCIS.

${ }^{75}$ Doravante, col.4-LPLI.
} 
O objeto de análise desse estudo, portanto, são as atividades efetivamente apresentadas no Livro do Professor. As orientações para condução da prática docente - presentes no M.P. - foram consideradas quando eram significativas para a compreensão valorativa das propostas das obras.

\subsubsection{Descrição geral das obras}

Cada uma das quatro coleções que integra a coletânea de LDP'sselecionados neste estudo possui três volumes, voltados para o $1^{\circ}$, $2^{\circ}$ e $3^{\circ}$ anos do ensino médio. A quantidade de páginas das obras varia entre 1080 e 1200, em cada coleção.

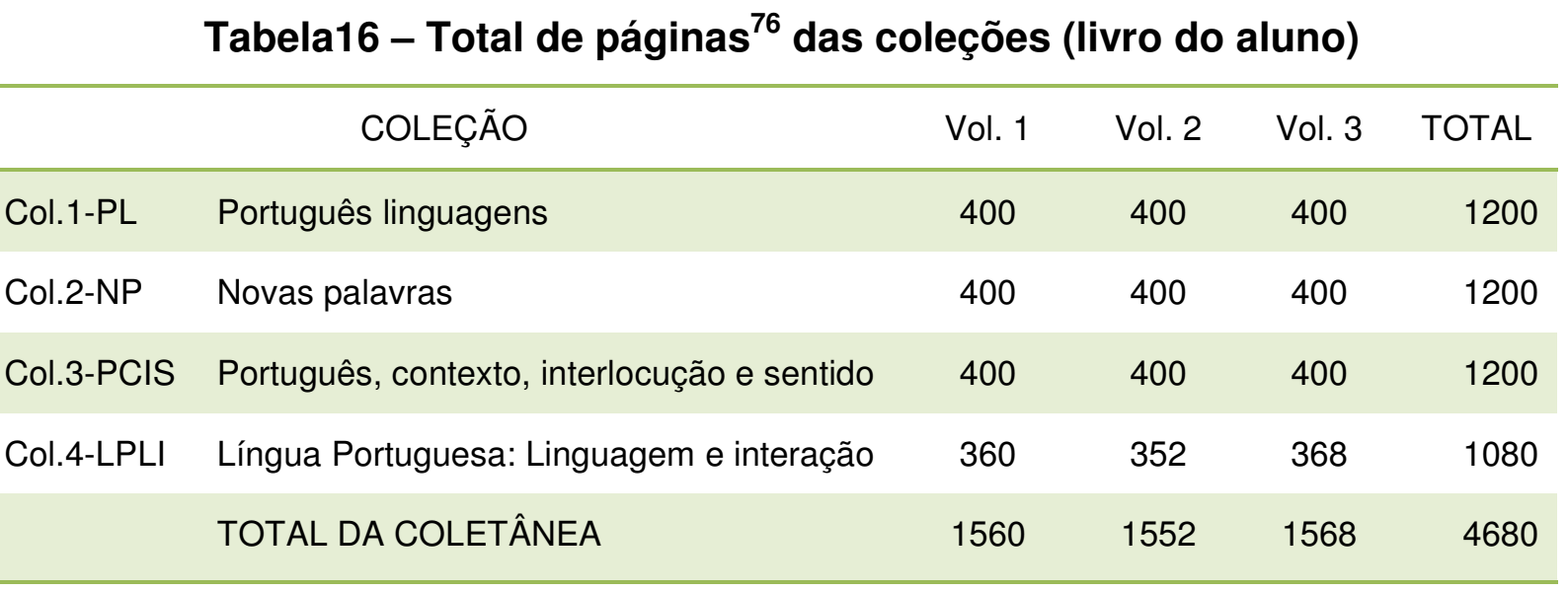

Fonte: Elaborado pela autora.

O número de páginas apresentado por volume é uma resposta ao que foi estabelecido pelo Edital, no tópicio 4.1.15: "Os livros impressos deverão ser apresentados com limite de páginas, conforme especificado abaixo. Máximo de páginas no livro do aluno: 400; máximo de páginas no manual do professor: $512 . "$ (BRASIL, 2013b, p. 2).

No processo de composição do LDP-EM, oEdital apresenta-se como uma voz autoritária, visto que o não cumprimento do limite de paginação pode levar à

\footnotetext{
${ }^{76}$ O edital do PNLD 2015, no tópico 4.1.15, estabeleceu o número de páginas máximo de cada volume de uma coleção: 400 páginas no livro do aluno e 512 no livro do professor (o que evidencia um limite de 112 páginas para o manual com orientações voltadas ao docente).
} 
exclusão da obra no processo de avaliação. Isso está explicitamente citado no item 3 do documento, que trata dos critérios de exclusão da triagem, código A14: "[será excluído o] livro impresso com número de páginas acima do limite previsto para cada componente curricular descritos no subitem 4.1.15". (BRASIL, 2013, p. 19).

As coleções selecionadas foram elaboradas em parceria por dois, três ou quatro autores, todos com formação em Letras (Graduação e/ou Licenciatura). Do total de doze autores da coletânea, apenas três não realizaram estudos de pósgraduação. Os demais profissionais têm formação de Especialista (1), de Mestre (3) ou de Doutor (5) na área de Língua Portuguesa, Literatura ou Linguística Aplicada.

No que tange à atuação profissional, todos os autores têm - ou já tiveram experiência na docência, em diferentes níveis de ensino: fundamental, médio e/ou superior. Alguns, ainda, declararam, no minicurrículo presente no início de suas obras, serem autores de outros livros - didáticos ou paradidáticos - e/ou trabalharem como consultores/assessores, pesquisadores ou coordenadores na área de Língua Portuguesa.

\section{Tabela17 - Singularidades dos autores das coleções ${ }^{77}$}

\begin{tabular}{|c|c|c|c|c|c|c|c|c|}
\hline \multirow[b]{2}{*}{ Coleção } & \multirow[b]{2}{*}{ Autores } & \multicolumn{4}{|c|}{ Formação acadêmica } & \multicolumn{3}{|c|}{ Atuação Profissional } \\
\hline & & Lic. & Esp. & $\mathrm{Me}$ & Do & Prof. & Aut. & $\begin{array}{l}\text { Cons. } \\
\text { / Pesq. }\end{array}$ \\
\hline \multirow{2}{*}{$\begin{array}{c}\text { Col.1- } \\
\text { PL }\end{array}$} & William Roberto Cereja & $\mathrm{X}$ & & $\mathrm{X}$ & $\mathrm{X}$ & $\mathrm{X}$ & $\mathrm{X}$ & \\
\hline & Thereza Cochar Magalhães & $\mathrm{X}$ & & $\mathrm{X}$ & & $\mathrm{X}$ & $\mathrm{X}$ & \\
\hline \multirow{4}{*}{$\begin{array}{c}\text { Col.2- } \\
\text { NP }\end{array}$} & Emília Amaral & $\mathrm{X}$ & & $\mathrm{X}$ & $\mathrm{X}$ & $\mathrm{X}$ & & $\mathrm{X}$ \\
\hline & Mauro Ferreira do Patrocínio & $\mathrm{X}$ & $\mathrm{X}$ & & & $\mathrm{X}$ & $\mathrm{X}$ & \\
\hline & Ricardo Silva Leite & $\mathrm{X}$ & & $\mathrm{X}$ & & $\mathrm{X}$ & & \\
\hline & Severino Antônio M. Barbosa & $\mathrm{X}$ & & $\mathrm{X}$ & $\mathrm{X}$ & $\mathrm{X}$ & $\mathrm{X}$ & \\
\hline \multirow{3}{*}{$\begin{array}{l}\text { Col.3- } \\
\text { PCIS }\end{array}$} & Maria Luiza MarquesAbaurre & $\mathrm{X}$ & & $\mathrm{X}$ & & $\mathrm{X}$ & & $\mathrm{X}$ \\
\hline & Maria BernardeteM.Abaurre & $\mathrm{X}$ & & $\mathrm{X}$ & $\mathrm{x}$ & $\mathrm{X}$ & & $\mathrm{x}$ \\
\hline & Marcela Pontara & $\mathrm{X}$ & & & & $\mathrm{X}$ & & $\mathrm{X}$ \\
\hline \multirow{3}{*}{$\begin{array}{l}\text { Col.4- } \\
\text { LPLI }\end{array}$} & Carlos Emílio Faraco & $\bar{X}$ & & & & $\mathrm{X}$ & & \\
\hline & Francisco Marto de Moura & $\mathrm{X}$ & & & & $\mathrm{X}$ & & \\
\hline & José Hamilton Maruxo Jr. & $\mathrm{X}$ & & $\mathrm{X}$ & $\mathrm{X}$ & $\mathrm{X}$ & & $\mathrm{X}$ \\
\hline
\end{tabular}

Fonte: Elaborado pela autora.

\footnotetext{
${ }^{77} \mathrm{O}$ perfil dos autores foi construído com base no minicurrículo apresentado no início dos volumes didáticos analisados. Assim, ainda que tenhamos o conhecimento de alguma informação dos autores (como o fato de Carlos Emílio Faraco e Francisco Marto de Moura serem autores de obras didáticas da década de 80/90), optamos por respeitar a declaração apresentada por eles em cada volume.
} 
OEdital estabelece como requisito mínimo para autoria das obras de Língua Portuguesa a formação na área (bacharelado ou licenciatura), podendo o autor ter, ainda, formação em nível de pós-graduação relacionada à disciplina didática para a qual o livro didático foi escrito. Para que seja comprovada a titulação declarada, as editoras devem entregar cópias dos diplomas dos autores para inscrição da obra junto ao MEC, conforme consta no item 6.4.1.8 do edital: "deverá ser entregue uma cópia autenticada do diploma, certificado ou declaração de conclusão de curso de graduação ou pós-graduação realizado pelo(s) autor(es) e coautor(es), emitido(a) por instituição de ensino superior." (BRASIL, 2013b, p. 7). Dessa forma, observamos, nesse aspecto, mais uma vez a voz autoritária do documento oficial para elaboração do LDP-EM.

\subsubsection{Distribuição dos conteúdos de ensino nas coleções}

Internamente, cada livro apresenta uma subdivisão por eixo de ensino, assim delimitado: Literatura ${ }^{78}$, Gramática $^{79}$ e Produção de Texto ${ }^{80}$. Essa divisão ora vem expressamente constituída em grandes blocos, dentro dos quais estão os capítulos (col.2-NP; col.3-PCIS), ora vem colocada como subdivisões internas dentro de unidades, em que os capítulos evidenciam os eixos (col.1-PL), ora apresentamse como seções internas, dentro dos capítulos (col.4-LPLI).

Assim, para o primeiro grupo de coleções, os conteúdos apresentam-se condensados: primeiro são topicalizados os estudos de literatura, em seguida os de gramática e, por fim, os de produção textual.

\footnotetext{
${ }^{78}$ Todas as quatro coleções apresentam o eixo "Literatura" como entrada para o trabalho com esse eixo de ensino. No entanto, a col.4-LPLI acrescenta um subtítulo: "Literatura: teoria e história".

${ }^{79}$ O eixo de "gramática" aparece assim nomeado em duas coleções: col.2-NP e col.3-PCIS.Nas demais, o termo usado foi "Língua: uso e reflexão" (col.1-PL) e "Língua: análise e reflexão" (col.4LPLI).

${ }^{80}$ Uma das coleções (col.2-NP) optou por nomear esse eixo de ensino como "Redação e leitura". As três outras usam a nomenclatura "produção de texto" (col.1-PL; col.3-PCIS) ou "produção escrita" (col.4-LPLI).
} 
Figura 8 - Divisão da obra por eixo de ensino: col. 2-NP

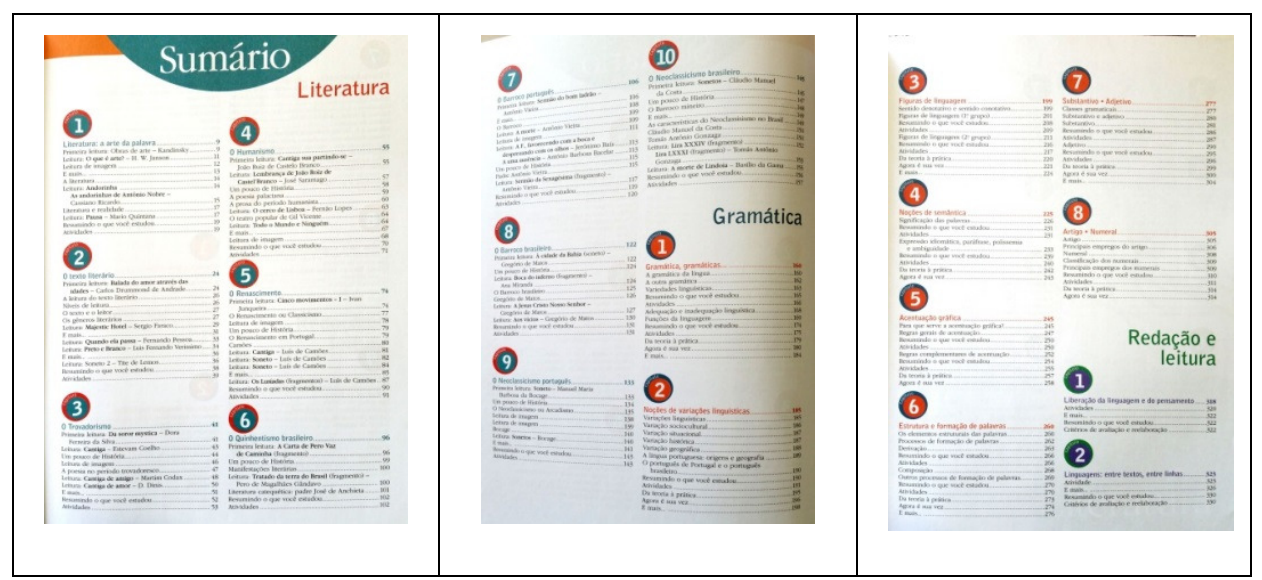

Sumário. AMARAL (et. al.), 2013a, p. 3-5.

Se, por um lado, essa organização facilita a rápida localização de uma informação, de acordo com o objetivo didático de ensino, por outro, constrói a noção de que o conhecimento é compartimentado, estanque. Como, em geral, os estudos literários estão em primeiro plano e a produção de texto em último, percebe-se a valorização daqueles em detrimento desta.

Para minimizar o problema, algumas coleções trazem, no manual do professor, orientações de trabalho não linear, para que o professor trabalhe ora com um eixo, ora com outro. Justifica-se, assim, a estrutura canônica apresentada na maioria das coleções da coletânea.

Procuramos preservar a autonomia do professor, possibilitando um uso flexível do livro (...). A organização em três grandes setores Literatura, Gramática e Redação e leitura - visa a essa flexibilidade, pois desobriga o uso linear do livro didático, permitindo a construção de programas adequados às condições específicas de cada unidade escolar, de cada turno e mesmo de cada turma.

Manual do professor. AMARAL (et. al.)., 2013a. p. 4.

O posicionamento apresentado nesse excerto do manual do professor dialoga com as OCEM, que defendem a autonomia de trabalho do professor na escola: "as orientações [apresentadas no documento] não devem ser tomadas como 'receitas' ou 'soluções' (...) e sim como referenciais (...)”. (BRASIL, 2006, p. 17). Este documento apresenta um caráter regulador para as ações práticas do professor do ensino médio. Para o processo de produção do LDP-EM, ele estabelece um diálogo 
como voz internamente persuasiva, visto que não impõem uma conduta obrigatória a ser seguida, mas tem força como voz de autoridade, já que é oficial.

Em relação ao segundo grupo, em que os eixos de ensino podem ser observados nos títulos dos capítulos que compõem uma unidade do livro, percebemos uma intenção de minimizar essa visão estanque, uma vez que, embora os capítulos continuem mostrando um trabalho isolado, eles estão ligados por um fio condutor, estabelecido no interior de uma proposta da unidade.

No vol. 3 da col.1-PL, por exemplo, a unidade 1 apresenta a seguinte organização:

Unidade 1 - História social do Modernismo

Cap. 1 - O Pré-Modernismo

Cap. 2 - A linguagem do Modernismo

Cap. 3 - A crônica

Cap. 4 - Vanguardas em ação

Cap. 5 - Período composto por subordinação: as orações

substantivas

Cap. 6 - O Modernismo em Portugal: a primeira geração

Cap. 7 - Período composto por subordinação: as orações adjetivas

Cap. 8 - A primeira fase do Modernismo. Os Andrades

Cap. 9 - O texto de divulgação científica

Cap. 10 - Manuel Bandeira e Alcântara Machado

Cap. 11 - O Enem e os cinco eixos cognitivos

Em dia com o Enem e o vestibular

Vivências

(CEREJA; MAGALHÃES, 2013c. p. 5-6)

A entrada de trabalho é com "literatura", nesta unidade, que acontece nos capítulos 1, 2, 4, 6, 8 e 10. O estudo da "produção de texto" é desenvolvido nos capítulos 3 e 9 e o de estudo da língua ("Língua: uso e reflexão") é feito nos capítulos 5 e 7. Assim, o trabalho com os eixos de ensino acontece de forma intercalada.

O último capítulo e a seção que se segue a este, ao final de cada unidade, enfatizam um trabalho voltado ao Enem $^{81}$. Inicialmente o enfoque recai na interpretação de texto, focado nas competências e habilidades estabelecidas para

\footnotetext{
${ }^{81}$ ENEM - Exame nacional do ensino médio - é um programa governamental voltado para avaliar os jovens egressos do último ciclo de estudos da educação básica. As notas que os jovens estudantes obtêm nessa prova têm sido utilizadas para o ingresso em faculdades públicas e privadas de todo o país. Considerando essa realidade, muitos livros didáticos têm optado por inserir capítulos ou seções nos LDP's para auxiliar o aluno a se preparar para essa prova.
} 
nortear esse exame nacional, e termina - na seção "Em dia com o Enem e o vestibular" - com uma seleção de perguntas de múltipla escolha e propostas de produção de texto coletadas de avaliações públicas (do Enem ou de vestibulares diversos) realizadas em anos anteriores.

Os autores da col.1-PL (CEREJA; MAGALHÃES, 2013c, p. 436) explicitam, no manual do professor, que todas as unidades da obra serão organizadas com foco na literatura: "Cada volume da coleção está organizado em quatro unidades. O critério de organização é dado pela literatura, de modo que em cada unidade é estudado um movimento literário ou parte dele". Assim, os capítulos dispostos internamente em cada unidade - com exploração de aspectos de estudo da língua, literatura e produção de texto - estarão, de certa forma, articulados sempre com este eixo de ensino.

Um movimento de maior integração entre os três eixos parece concretizar-se na organização do terceiro perfil estrutural de uma coleção do corpus(col.4-LPLI), em que os eixos de ensino estão internamente distribuídos no capítulo.

\section{Tabela 18 - Organização estrutural da col.4-LPLI}

Unid. 1 - Das histórias do passado às histórias do presente

- Texto 1

- Para entender o texto

- As palavras no contexto

- Gramática textual

- Literatura: teoria e história

- Linguagem oral

○ Língua: análise e reflexão

- Prática de linguagem

- Produção escrita

- Para ir mais longe
Cap. 2 - Novela

- Texto 1

- Para entender o texto

- As palavras no contexto

- Gramática textual

- Literatura: teoria e história

- Linguagem oral

- Língua: análise e reflexão

- Prática de linguagem

- Produção escrita

- Para ir mais longe
- Texto 1

Cap. 3 - Crônica

- Para entender o texto

- As palavras no contexto

○ Gramática textual

- Literatura: teoria e história

○ Linguagem oral

○ Língua: análise e reflexão

○ Prática de linguagem

- Produção escrita

- Para ir mais longe

Fonte: FARACO; MOURA; MARUXO JR., 2013a, p. 4-5.

A partir da tabela anterior, que apresenta uma unidade do vol. 1, é possível observar que as unidades da col.4-LPLIsão organizadas por temáticas, os capítulos por gêneros e os eixos de ensino são seções internas de cada um deles. Essa forma de estruturação evidencia uma maior articulação entre os eixos de literatura, gramática e produção textual euma consequente preocupação com a inter-relação entre eles. 
Os autores da obra justificam essa escolha afirmando que:

Essa estrutura de cada unidade cria um percurso interno que pode levar os alunos e o professor a desenvolver um projeto comum e coletivo de trabalho, capaz de articular as dimensões do ensino da língua entre si e com a(s) temática(s) enfocada(s) da unidade, permitindo ainda a exploração interdisciplinar de algumas dessas temáticas.

FARACO, MOURA e MARUXO JR., 2013b, p. 357.

Importante destacar que há duas seções voltadas para compreensão de texto ("Para entender o texto" e "As palavras no contexto"), bem como uma seção que apresenta, explicitamente, que a obra buscará realizar algum trabalho com oralidade ("Linguagem oral").

Traçamos, assim, o perfil estrutural das obras que compõem a coletânea: os eixos de ensino são o principal fator de organização dos LDP-EM observados, seja pela entrada como grande bloco de estudo (duas coleções), seja pela organização dos capítulos que compõem uma unidade (uma coleção), seja pela distribuição dos eixos de literatura, gramática e produção textual ao longo dos capítulos que compõem a obra (uma coleção).

A partir desse perfil, compreendemos a organização macroestrutural de conteúdo da coletânea. Interessa-nos, no entanto, observar mais detidamente o que é proposto no trabalho com gêneros orais no interior dos LDP-EM.

\subsubsection{Presença de gêneros orais na coletânea}

O levantamento dos gêneros orais presentes em cada coleção foi feito página a página, pois no sumário não havia destaque para esse conteúdo. Os dados dessa leitura estão disponíveis nos anexos 3, 4, 5 e 6 (e suas subdivisões). A partir dele, é possível observar que são 26 os gêneros mencionados nos volumes. 


\section{Tabela 19 - Gêneros orais em quatro coleções do PNLD 2015}

\begin{tabular}{|c|c|c|c|c|}
\hline \multirow{2}{*}{$\begin{array}{l}\text { Relação de gêneros orais presentes no } \\
\text { interior das obras }\end{array}$} & \multicolumn{4}{|c|}{ Recorrência do gênero oral na: } \\
\hline & Col.1-PL & Col.2-NP & Col.3-PCIS & Col.4-LPLI \\
\hline Apresentação oral & --- & 15 & 3 & --- \\
\hline Aula & --- & --- & --- & 1 \\
\hline Canção & 14 & --- & 23 & 12 \\
\hline Conto de fada / maravilhoso (contação) & --- & --- & --- & 4 \\
\hline Conversa cotidiana & --- & --- & --- & 1 \\
\hline Conversa telefônica / recado telefônico & --- & 1 & --- & 4 \\
\hline Debate / Debate regrado público & 4 & 16 & 5 & 9 \\
\hline Discurso político & --- & --- & --- & 1 \\
\hline Documentário & --- & 1 & --- & --- \\
\hline Entrevista & 1 & 1 & --- & 7 \\
\hline Exposição oral & 2 & --- & 3 & 15 \\
\hline Lenda / mito (contação) & --- & --- & --- & 3 \\
\hline Mesa-redonda & 1 & --- & 1 & 5 \\
\hline Peça teatral / Esquete / Encenação & 3 & 4 & --- & 4 \\
\hline Parlenda / máxima / provérbio & --- & --- & --- & 1 \\
\hline Piada / anedota (contação) & --- & 1 & --- & 1 \\
\hline Poema (declamar) & 5 & --- & --- & --- \\
\hline Propaganda (rádio) & --- & --- & --- & 1 \\
\hline Relato oral & --- & --- & 1 & --- \\
\hline Roda de conversa & 6 & 56 & 30 & 17 \\
\hline Roda de discussão & 1 & 19 & 23 & 16 \\
\hline Seminário & 1 & --- & --- & --- \\
\hline Sermão & --- & --- & --- & 1 \\
\hline Spot de rádio & --- & --- & 1 & --- \\
\hline Telenovela & --- & --- & --- & 2 \\
\hline Telejornal & --- & --- & --- & 1 \\
\hline
\end{tabular}

Fonte: Elaborado pela autora

A diversidade apresentada pode ser reorganizada se considerarmos a finalidade de cada uma das atividades propostas. Há gêneros que, embora sejam escritos, foram tomados como foco do trabalho oral da coleção para o desenvolvimento de uma contação (conto, lenda, mito, piada, anedota) ou para declamação (poema). Outros, marcadamente orais (canção), embora também tenham um suporte escrito (a letra da canção) aparecem como recurso de apreciação sonora ou para funcionar como uma atividade intertextual, ligando os conceitos literários estudados com a música sugerida.

Nos dois casos, percebe-se uma aproximação com os documentos oficiais Edital e OCEM - por propiciarem o desenvolvimento da capacidade de escuta dos alunos. Essa relação entre o escrito e o oral também permite discutir um pouco sobre as especificidades de cada um desses modos de produção do enunciado. 
Embora não tenha sido esse o propósito da maioria dessas atividades, considerando as potencialidades do LDP como acontecimento, entendemos que essas aproximações poderiam ser feitas pelo professor.

Nas coleções, algumas orientações de trabalho com gêneros orais pressupõem o uso de televisão, rádio ou telefone: telenovela, telejornal, spot de rádio, propaganda de rádio, conversa telefônica. Essas foram atividades bem pontuais, presentes em duas coleções apenas, mas que evidenciam um diálogo com os estudiosos que trabalharam nessa linha, como mostrado no capítulo 1. Atuam, portanto, como voz de autoridade, internamente persuasiva, na condução da proposta.

Presente em todos os volumes e com um grande número de recorrência foi a orientação de roda de conversa e roda de discussão. A primeira é orientada quase sempre no início da unidade de cada volume, com o intuito de estimular uma primeira aproximação do aluno sobre o tema / conteúdo que será abordado. A segunda foi mais comum no interior dos capítulos, advindas quase sempre de propostas de discussão sobre algum tema subjacente à atividade. Nesta, havia uma proposta mais direcionada para a realização da tarefa que a primeira. Ainda assim, nos dois casos, o foco estava no uso da língua em situação escolar, funcionando mais como prática social.

O gênero peça teatral também foi orientado em três coleções é era usado ora como recurso para consolidação de uma atividade, para reforçar os conteúdos aprendidos, ora como oportunidade de expressão. Como objeto de ensino, porém, não havia uma orientação mais pontual.

De forma geral, a exposição oral e a apresentação oral foram tratadas de forma confusa, ficando difícil compreender, a partir das atividades observadas, as diferenças entre elas. Ora havia uma distinção mais clara, em que a exposição era tomada como objeto de ensino e a apresentação como estratégia de divulgação de algum estudo de forma menos sistematizada, ora essas nomenclaturas misturavamse para tratar de coisas semelhantes.

Alguns gêneros foram marcadamente trabalhados como objeto de ensino: discurso político, entrevista, mesa-redonda e seminário. Esses, no entanto, não foram abordados em todas as coleções. O gênero debate, porém, foi mencionado 
nas quatro coleções estudadas, motivo pelo qual optamos por selecionar esse gênero para análise.

A seguir, explicitaremos o percurso metodológico que trilhamos para guiar nosso olhar na análise das atividades de debate no LDP-EM epara responder as questões de pesquisa apresentadas na introdução desse trabalho.

\subsection{Percurso teórico-metodológico e categorias de análise}

Discutir sobre gêneros orais é pensar a produção oral como um enunciado concreto, e, portanto, somente considerável no interior de uma prática social discursiva. Também implica, numa perspectiva bakhtiniana, considerar a singularidade do evento, evitando generalizações que levem a uma padronização e, assim, a uma concepção abstrata do que seja o oral.

Aliás, como nos alerta Schneuwly (1997, apud ROJO, 2001, p. 56), "o oral não existe; existem orais: atividades de linguagem realizadas oralmente; gêneros que se praticam essencialmente por meio da oralidade. Ou então atividades de linguagem que combinam o oral e o escrito".

Considerando que essas múltiplas práticas de linguagem, ocorridas no modo oral, são enunciados concretos, entendemos que será pertinente, como orientação metodológica para a análise do corpus, observar nas propostas didáticas dos LDPEM se os três fatores que constituem o enunciado (VOLOCHINOV, 1926/2013, p. 78), evidenciando sua forma arquitetônica,são considerados. Em outras palavras, verificar se, na orientação da atividade, há espaço para que o aluno reflita sobre:

(1) o horizonte espacial compartilhado entre os falantes (unidade visível).

(2) o conhecimento e compreensão comum da situação (unidade pressuposta)

(3) a valoração da situação, igualmente partilhada pelos dois (unidade avaliativa).

Outro conceito fundamental para guiar nosso olhar sobre as atividades didáticas apresentadas nas coleçõesé o derelações dialógicas, fundamentado na teoria dialógica do discurso, conforme apresentamos em nosso capítulo teórico.

Tomamos como ponto de partida as três dimensões que o diálogo pode assumir: micro-diálogo, diálogo e grande diálogo. Para Souza (2002), o primeiro refere-se ao diálogo interior, o segundo ao exterior e o último ao diálogo de outrem. 
Estas dimensões, segundo ele, podem ser úteis para entender o olhar do pesquisador frente ao seu objeto.

A vida do enunciado concreto se encontra realizada nessas três dimensões do diálogo. Do ponto de vista do pesquisador, (...):

a) A primeira [micro-diálogo] não é acessível ao pesquisador, embora ele saiba de sua existência concreta por experiência própria. Sendo assim, ela só pode ser observada em sua representação literária no diálogo do herói com ele mesmo.

[eu para mim]

b) A segunda compreende o diálogo de duas ou mais pessoas onde a resposta é, em geral, imediata, existe alternância de sujeitos. Nesse caso, o pesquisador é o terceiro, cujo olhar exterior consegue perceber a relação eu/outro efetivada no diálogo. [eu para o outro]

c) A terceira corresponde à dimensão de resposta não imediata, onde as relações dialógicas entre os enunciados concretos, vivos, constrói [sic] o fenômeno (...) do discurso de outrem - do enunciado de outrem - que adentra a estrutura do enunciado, isto é, 0 interior do meu discurso. (...) [outro para mim]

(SOUZA, 2002, p. 81-82, grifo nosso)

O autor, em sua leitura sobre o papel do pesquisador, dialoga com Bakhtin no que tange ao conceito de arquitetônica do mundo real no ato, evidenciando, assim, os momentos fundamentais dessa concretização: o eu-para-mim, o eu-parao-outro e ooutro-para-mim. Nas palavras de Bakhtin:

Estes momentos fundamentais [da construção e da disposição recíproca do ato singular] são: eu-para-mim, o outro-para-mim e eupara-o-outro; todos os valores da vida real e da cultura se dispõem ao redor destes pontos arquitetônicos fundamentais do mundo real do ato (...).

(BAKHTIN, 1920-24/2010, p. 114)

$\mathrm{Na}$ leitura de nosso corpus, portanto, entendemos ser possível observar tanto os aspectos dialógicos relativos ao enunciado, num movimento de mim-para-ooutro, como os que se referem a aspectos histórico-sociais que nele se materializam, evidenciando o diálogo do-outro-para-mim.

Também serão significativos para nossa análise os conceitos de discurso autoritário e discurso internamente persuasivo, explicitados no tópico 4.2, tanto para a compreensão das atividades didáticas, quanto para a percepção do diálogo que elas constroem com os documentos oficiais: Edital e OCEM. 


\section{Tabela20 - Orientação teórico-metodológica para análise}

\begin{tabular}{|c|c|}
\hline Instância teórica & Percurso metodológico de observação \\
\hline $\begin{array}{l}\text { Forma arquitetônica } \\
\text { do enunciado }\end{array}$ & $\begin{array}{l}\text { 1) Horizonte espacial compartilhado } \\
\text { 2) Conhecimento e compreensão comum da situação } \\
\text { 3) Valoração partilhada da situação }\end{array}$ \\
\hline $\begin{array}{l}\text { Relações dialógicas } \\
\text { do enunciado no ato }\end{array}$ & $\begin{array}{l}\text { 1) Diálogo no sentido estrito: exterior/imediato. } \\
\text { (eu-para-o-outro) } \\
\text { 2) Diálogo no sentido largo: grande diálogo com a } \\
\text { história/cultura. (outro-para-mim) }\end{array}$ \\
\hline $\begin{array}{l}\text { Formas de apropriação do } \\
\text { discurso alheio }\end{array}$ & $\begin{array}{l}\text { 1) Discurso autoritário } \\
\text { 2) Discurso internamente persuasivo }\end{array}$ \\
\hline
\end{tabular}

Fonte: VOLOCHINOV, 1926/2013; BAKHTIN, 1920-24/2010.

Por uma perspectiva sócio-histórica-discursiva, evidenciamosas vozes presentes nos enunciados do LDP-EM - pelo diálogo com conceitos acadêmicos consolidados e com os documentos oficiais - Edital e OCEM - que dão suporte a ele - e o centro de valores, a forma arquitetônica, que se observa a partir das escolhas feitas pelos autores na constituição da obra.

Campos (2012), estudando a leitura de textos verbo-visuais especificamente anúncios publicitários - em um Livro Didático de Língua Portuguesa, apropria-se do conceito de arquitetônica para desenhar um percurso teórico-metodológico possível para uma análise de cunho bakhtiniano, a saber:

(...) na primeira etapa da sequência analítica, identificam-se as partes que compõem o objeto, na segunda, analisam-se como as partes se articulam construindo sentidos e, por fim, as relações dialógicas construídas desse movimento é a repercussão histórica, social e cultural do objeto no seu tempo e espaço.

(CAMPOS, 2012, p. 251.)

Entendemos, assim, que esse percurso seja relevante para guiar nosso olhar em relação às atividades com gêneros orais que compõem o LDP-EM.

Com vistas a conhecer e compreender melhor nosso objeto de estudo, tomamos a entonação expressiva como categoria de análise, a partir da qual 
focalizaremos dois eixos norteadores: (1) valoração e vozes sociais no enunciado do LDP-EM; e (2) valoração orientada para a tomada de posição do aluno.

Para fins de aprofundamento de nosso estudo, selecionamos para análise apenas as atividades que propunham um trabalho com o debate. Essa escolha se deu por dois motivos: por esse gênero estar presente nas quatro coleções selecionadas e por ser, dentre todos os gêneros orais formais públicos, o mais recorrente no conjunto da coletânea.

A partir desse recorte, dos critérios de análise apresentados e considerando nossas perguntas de pesquisa, focalizando neste estudo, por um lado, como 0 gênero debate é tratado em cada uma das coleções selecionadas e, por outro, como são construídas as relações dialógicas presentes no interior dessas atividades.

No capítulo de análise, objetivamos demonstrar como o gênero debate é tratado no interior da obra, tanto como objeto de ensino, quanto em relação às proposições de uso, como prática social.

$\mathrm{Na}$ conclusão, buscaremos evidenciar as relações dialógicas presentes não apenas no interior de cada obra, mas na relação com as demais coleções que compõem nossa coletânea, evidenciando a repercussão histórica, social e cultural que delas se observa no tempo e espaço. Entendemos, com isso, que será possível compreender como se constrói a arquitetônica do gênero debate em toda a coletânea.

Passemos, pois, no próximo capítulo, à análise das atividades propostas com esse gênero nas obras selecionadas. 


\section{CAPÍTULO 5}

\section{A PRESENÇA DO GÊNERO DEBATE NO LIVRO DIDÁTICO DE PORTUGUÊS DO ENSINO MÉDIO}

(...) é muito importante toda a situação em que se deu a fala: quem a presenciou, com que expressão, com que mímica foi falado, quais foram os matizes da entonação.

(BAKHTIN, 2015, p. 134)

No presente capítulo, apresentamos a análise das atividades em que a produção de "debate" é orientada no interior do livro didático de português do ensino médio nas quatro coleções selecionadas do PNLD 2015: Português linguagens (CEREJA; MAGALHÃES, 2013d), Novas palavras (AMARAL et al, 2013d), Português: contexto, interlocução e sentido (ABAURRE; ABAURRE; PONTARA, 2013d) e Língua Portuguesa: linguagem e interação (FARACO; MOURA; MARUXO JR., 2013d).

Considerando as discussões do LDP-EM, apontamos que práticas de debate são propostas, que diálogos elas constituem com documentos oficiais e como os sujeitos são chamados a se posicionar criticamente, assumindo sua voz para uma tomada de posição crítica nas situações de interação. 


\subsection{O debate como objeto de ensino em Português Linguagens}

O Manual do Professor ${ }^{82}$ da coleção Português Linguagens (col.1-PL) apresenta brevemente uma explicação teórica sobre o que sejam os gêneros do discurso, momento em que se faz menção tanto à definição bakhtiniana de gênero: "todos os textos que produzimos, orais ou escritos, apresentam um conjunto de características relativamente estáveis (...)"; quanto às especificidades de sua escolha na vida concreta: "Quando estamos numa situação de interação verbal, a escolha do gênero não é completamente espontânea (...)" / "Por exemplo, se desejamos contar a alguém uma experiência pessoal que vivemos, podemos fazer uso de um relato pessoal (...)". (CEREJA e MAGALHÃES, 2013c, p. 417)

Há também, no MP, menção aos trabalhos do grupo de pesquisadores de Genebra (Dolz, Schneuwly e outros), que tratam o gênero como ferramenta e propõem o estudo deste em espiral por sequência didática, cuja progressão deve estar presente.

Embora não haja uma menção específica ao gênero "debate", fica clara no MP uma visão de língua ligada a práticas sociais, visto que o uso de gêneros discursivos, sejam quais forem, deve estar associado a uma situação concreta de uso: "um poeta escreve poemas para publicá-los num livro; um jornalista escreve notícias e reportagens para publicá-las num jornal ou em uma revista". (CEREJA e MAGALHÃES, 2013c, p. 419).

Os excertos citados evidenciam um diálogo tanto com a teoria dialógica do discurso, quanto com as pesquisas dos autores genebrinos. Essa menção no MP atende a uma exigência do Edital, em que se estabelece que as orientações teóricas metodológicas devem configurar no interior da obra.

2.1.3. Coerência e adequação da abordagem teórico-metodológica assumida pela obra no que diz respeito à proposta didáticopedagógica explicitada e aos objetivos visados.

Por mais diversificadas que sejam as concepções e as práticas de ensino envolvidas na educação escolar, propiciar ao aluno uma efetiva apropriação do conhecimento implica: a) escolher uma abordagem metodológica capaz de contribuir para a consecução dos objetivos educacionais em jogo; b) ser coerente com essa escolha, do ponto de vista dos objetos e recursos propostos.

${ }^{82}$ Doravante, MP. 
Em consequência, serão excluídas as obras didáticas que não atenderem aos seguintes requisitos:

(1) explicitar, no manual do professor, os pressupostos teóricometodológicos que fundamentam sua proposta didáticopedagógica;

(BRASIL, 2013b, p. 41. Grifo nosso.)

A citação teórica do MP entra na obra como uma palavra alheia que atende a uma exigência oficial. Podemos entendê-la de duas formas. Por um lado, como discurso autoritário (BAKHTIN, 1930-36/2015), pois responde a um edital oficial e, se o critério estabelecido não for atendido, a obra é excluída do processo de avaliação. Por outro, como discurso internamente persuasivo (op. cit.), visto que uma proposta baseada em preceitos consolidados cientificamente dá força para validar as atividades de maneira positiva, por trazer a voz de pesquisadores.

A col.1-PL apresenta quatro propostas para realização de debate: dois como um capítulo à parte, em que o gênero é tomado como objeto de ensino (vol. 1 e 3), e dois em que ele integra um conjunto de várias ações a serem realizadas pelo aluno no interior de uma prática social (ambos no vol.3).

No vol. 1, na última unidade, o capítulo 2, intitulado "O debate regrado público", organizado com sete páginas, apresenta a seguinte configuração:

Tabela 21 - Debate regrado público, no vol.1 - col.1-PL

\begin{tabular}{|c|c|c|}
\hline & Título & Capítulo 2 - 0 debate regrado público \\
\hline 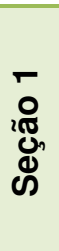 & $\begin{array}{l}\text { "Trabalhando } \\
\text { o gênero" }\end{array}$ & $\begin{array}{l}\text { Propostas } \\
\text { - Leitura de três parágrafos introdutórios que contextualizam o gênero } \\
\text { "debate". } \\
\text { - Leitura de um debate transcrito. } \\
\text { - Resposta a dez perguntas sobre o texto (reflexão sobre aspectos do } \\
\text { gênero e sobre o conteúdo da leitura). }\end{array}$ \\
\hline 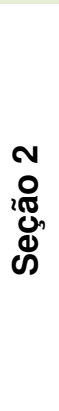 & $\begin{array}{c}\text { "Produzindo o } \\
\text { debate } \\
\text { regrado" }\end{array}$ & 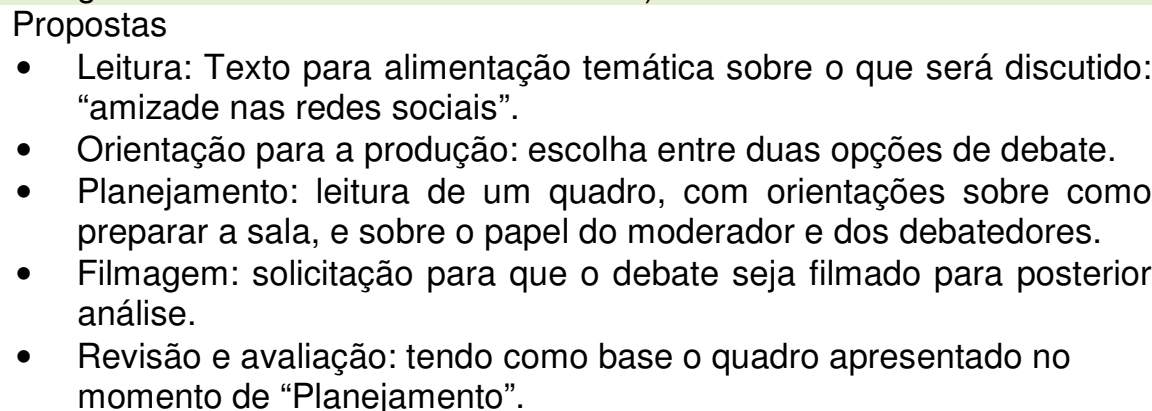 \\
\hline
\end{tabular}

Fonte: CEREJA e MAGALHÃES, 2013a. p. 327-333. 
O capítulo apresenta-se dividido em duas seções. A primeira delas Trabalhando o gênero - traz, inicialmente, três parágrafos que procuram mostrar duas situações em que podemos usar a argumentação oral: uma cotidiana (de conversas familiares, por exemplo) e outra formal (e é nesta que o gênero debate regrado está situado). Seguido a isso, o aluno é orientado a ler um texto de duas páginas, cujo título é "Orkut, MSN, YouTube: paquera e narcisismo na Internet". Trata-se de um debate transcrito.

A preocupação em apresentar um texto que teve uma circulação real está em consonância com a proposta declarada no MP de buscar sempre a contextualização do gênero em seu uso concreto, como prática social. Esse diálogo também se concretiza, pelo mesmo motivo, com as OCEM (BRASIL, 2006).

Considerando a natureza material do LDP-EM e a ausência de um CD que acompanhe a obra, entendemos que a transcrição do debate é uma solução pertinente. No entanto, no texto transcrito foram omitidas as marcas de oralidade que poderiam favorecer um trabalho ligado aos aspectos intrínsecos à linguagem oral.

As questões propostas após a leitura desse debate focalizam quatro aspectos: (1) função dos interlocutores do discurso (quem exerce o papel de mediador e quais são suas obrigações); (2) compreensão textual; (3) organização textual da argumentação no interior do debate; (4) reflexão sobre a linguagem empregada.

Os enunciados propostos nas questões de leitura também trazem as características imbricadas na situação de produção do discurso. A explicação apresentada no enunciado é trazida como algo dado, o que minimiza a possibilidade de $o$ aluno trazer suas próprias experiências para dialogar com a atividade.

1. Num debate regrado público, há geralmente um coordenador e organizador, chamado mediador ou moderador. Além de conduzir o debate, cabe a ele, juntamente com os participantes, definir as regras e colocá-las em prática durante o evento. De modo geral, 0 moderador procura fazer poucas interferências.

a) No debate lido, quem desempenha o papel de moderador?

b) No decorrer do debate, se o moderador percebe que a discussão sobre determinado aspecto do tema está perdendo força, ou se julga que o debate ficaria mais enriquecido se fosse incluído outro aspecto, ele tem a liberdade de fazer perguntas aos 
debatedores, pedir a um ou a outro participante que dê exemplo ou explique melhor sua afirmação, etc. No debate em estudo, o moderador faz alguma interferência desse tipo? Em caso afirmativo, identifique o trecho em que isso ocorre.

(CEREJA; MAGALHÃES, 2013a, p. 329-330)

No que tange ao estilo do gênero, o aluno é orientado a localizar no texto expressões que evidenciam a tomada de um ponto de vista e, em seguida, levado a observar o grau de formalidade ou informalidade do discurso.

6. Ao argumentar, um debatedor expressa seu ponto de vista. Por isso, é comum o emprego de expressões, como na minha opinião, para mim, do meu ponto de vista. Há, no debate lido, expressões como essas? Se sim, dê exemplos.

7. Geralmente, nos debates públicos predomina a norma culta, menos ou mais formal, dependendo do perfil sociocultural dos participantes: idade, hábitos linguísticos, grau de escolaridade, profissão, grau de intimidade que têm entre si, etc. Observe a linguagem empregada pelos participantes do debate lido.

a) O que predomina: a formalidade ou a informalidade?

b) Identifique marcas de oralidade nas falas de Fernando Bonassi.

8. A que tipo de público o debate regrado público se destina?

(CEREJA; MAGALHÃES, 2013a, p. 330)

A pergunta que focaliza o público do debate aparece após o questionamento sobre o grau de formalidade/informalidade da linguagem e a única observação sobre a relação entre estilo e interlocutores do discurso ocorre de forma expositiva no enunciado da questão sete.

No que tange às "marcas de oralidade", citadas no enunciado da questão $7 \mathrm{~b}$, o livro do professor traz como resposta possível: "A mistura de pronomes de pessoas diferentes do discurso esta/isto no lugar de essa/isso, e vice-versa; o uso das expressões esta coisa de, uma coisa; uso de gíria (bacana)." (CEREJA; MAGALHÃES, 2013a, p. 330). No primeiro caso, os diferentes usos de pronomes estão mais relacionados a uma mudança em curso na língua (BAGNO, 2011), visto que ocorrem tanto na fala, quanto na escrita e estão presentes no discurso de sujeitos de diferente nível sócio-econômico-cultural. Não podem ser, assim, entendidos como "marcas de oralidade". Da mesma forma, a questão da gíria está menos ligada ao modo de produção do discurso (oral/escrito) e mais relacionada aos 
destinatários envolvidos (neste caso, jovens). Daí ser complicada a condução didática proposta.

Após a apresentação das questões para o aluno, inicia-se a segunda seção - Produzindo o debate regrado - em cujo enunciado observa-se a possibilidade de o aluno escolher entre dois temas de interlocução: "Há, a seguir, duas propostas para a realização de debates regrados. Com a orientação do professor, realize ao menos uma das propostas". (CEREJA; MAGALHÃES, 2013a, p. 330)

Antes, porém, o aluno é convidado a ler uma reportagem sobre as amizades da internet e a reler outra sobre o compartilhamento de senhas na web. Essa ação didática funciona como alimentação temática para motivar a discussão solicitada:

1. Debata com os colegas o seguinte tema: As amizades feitas pela Internet são reais e duradouras mesmo sem a presença física do outro? Ao tratar do tema, procurem considerar se, ao contrário, 0 relacionamento virtual leva as pessoas a se isolar e encontrar dificuldades para fazer amizades sólidas fora do círculo da Internet.

2. Releia o texto "Adolescentes abrem mão da privacidade e dividem senhas na Web", que se encontra na página 264. Depois debata com seus colegas: Os namorados devem dividir as senhas na Web? Por quê?. Prepare-se para debater o tema lendo o quadro "Planejamento do debate regrado público". Em seguida, junto com os colegas, elejam o moderador, definam as regras e iniciem o debate.

(CEREJA; MAGALHÃES, 2013a, p. 332. Grifos dos autores.)

No que se refere à primeira proposta, o texto dado para a leitura sugere uma resposta negativa - as amizades não são duradouras. Além disso, o próprio enunciado da questão também direciona o olhar do aluno para uma visão negativa dessas relações: "o relacionamento virtual leva as pessoas a se isolar..." (op. cit., p. 332). Há, portanto, um direcionamento que pode levar o aluno a apenas concordar com o que foi dito antes, reproduzindo o discurso da reportagem.

Essa proposta pode levar a um apagamento da voz do aluno, minimizando, assim, a possibilidade de este se colocar como autor de seu próprio discurso.

Para nós, se a proposta didática do LDP-EM, para o ensino do gênero oral debate, propõe apenas uma orientação temática para guiar o aluno sobre o que dizer, ou apresenta instruções ligadas à situação mais imediata da produção do discurso, pode estar pecando ao não levar o aluno a perceber que esse dito, por 
estar situado na vida, dela não pode ser separado, daí a necessidade de se compreender também os valores implicados na situação. Assim, mais que palavras sobre determinado assunto, o enunciado produzido possui uma valoração e a forma desse dizer carregado de valor axiológico - a entonação expressiva - deve ser considerada para se atingir a finalidade comunicativa, tendo em vista os interlocutores envolvidos e a situação mais ampla que envolve o enunciado.

No que tange à segunda proposta, percebemos o mesmo tipo de encaminhamento em que as respostas já foram dadas e resta ao aluno apenas reproduzir um discurso já dado. Isso ocorre, porque o texto orientado para releitura também apresenta uma visão negativa da questão proposta: segundo a reportagem, os namorados não deveriam dividir senhas na Web.

Em seguida, a obra traz o quadro "Planejamento do debate regrado público", em que são apresentadas informações de como organizar a sala para o debate e o que o moderador deve fazer.

\section{Preparação da sala}

- Não há uma disposição obrigatória da sala para a realização do debate. Se o número de participantes for pequeno, é possível que todos se sentem em círculo. Se, entretanto, forem muitos os participantes (debatedores e/ou público), as pessoas devem ocupar as cadeiras normalmente, conforme a disposição original da sala.

O moderador

- Posicione-se em pé na sala, numa posição central, de modo que possa ver e ser visto por todos.

- Inicie os trabalhos cumprimentando o público e apresentando o tema a ser debatido. Faça algumas considerações sobre o tema ou sobre a importância daquele debate e lembre as regras previamente estabelecidas.

- Se julgar necessário, indique uma pessoa para secretariar os trabalhos, fazendo as inscrições das pessoas que desejam falar.

- Ao passar a palavra a um debatedor, utilize expressões como "Vamos ouvir a opinião de fulano", ou "Fulano, sua vez".

- Faça sinais para os debatedores alguns segundos antes do término da fala (por exemplo, 10 ou 15 segundos), a fim de alertá-los sobre o tempo.

- Interfira no debate ao perceber que o debatedor está apresentando um argumento pouco claro ou superficial, fazendo perguntas como "Por quê?", pedindo que dê exemplo ou que explique melhor determinada afirmação. 
- Interfira sempre que houver na sala ruídos ou conversas paralelas que atrapalhem o andamento dos trabalhos.

CEREJA; MAGALHÃES, 2013a, p. 332.

As orientações dadas enfocam aspectos ligados ao espaço físico (como devem ficar as cadeiras, onde ficará o público, onde ficará o debatedor), às ações do moderador (cumprimentar a todos, selecionar um "secretário", passar a palavra, indicar término do tempo para os debatedores, fazer pequenas intervenções para ampliar a discussão, controlar as conversas da sala) e, por fim, aos usos linguísticos pertinentes para dar voz ao outro: "Vamos ouvir a opinião de fulano", "Fulano, sua vez". (op. cit., p. 332).

Considerando que este gênero está sendo explorado pela primeira vez na coleção, consideramos este detalhamento válido e pertinente. Preocupa-nos, apenas, a indicação desses usos de forma expositiva, sem reflexão a partir de um debate real, o que poderia ser sugerido se não no livro do aluno, ao menos o manual do professor. Sendo assim, percebe-se que o docente precisará assumir uma postura ativa no ensino, fazendo as complementações que o LDP-EM, como acontecimento, exige.

A segunda parte do quadro foca na ação dos debatedores e evidencia como eles devem organizar o tempo do debate, quais os procedimentos para o momento da interação, que expressões corporais são relevantes e que aspectos da língua podem ser observados para o momento da interação.

Sobre o primeiro aspecto sobre o debatedor, a obra coloca:

Tempo

- Os debatedores devem ter igualdade de condições e de tempo para expor suas ideias.

- Não se alongue com informações secundárias ou supérfluas, pois corre o risco de não concluir o pensamento por falta de tempo.

- Vá ao ponto principal logo no início da fala e, se possível, use o restante do tempo com exemplos.

- Durante a fala de outro debatedor, anote o nome dele e o argumento que ele apresentou. Posteriormente, se for retomar ou combater esse argumento, consulte suas anotações.

Fonte: CEREJA; MAGALHÃES, 2013a, p. 332. 
Nesse discurso há uma mudança de interlocutor. O primeiro enunciado fala do debatedor em terceira pessoa ("os debatedores devem..."), enquanto nos demais tópicos, o discurso está voltado para o próprio debatedor ("Vá ao ponto principal..."; "consulte suas anotações"). Considerando que é papel do moderador, segundo o quadro, fazer o controle desse tempo, essa informação sobre igualdade de tempo poderia ter sido inserida após o tópico que orienta sobre o aviso de término do tempo (5ํo tópico do item "o moderador").

No que tange às orientações dadas, os tópicos dois e três remetem para a importância do foco em relação ao que se pretende dizer e o último direciona para a necessidade da contra-argumentação, aspectos esses relevantes em um debate.

Em relação ao segundo aspecto - procedimento -, o LDP-EM enfatiza três pontos ligados ao momento de interação: (1) "nunca leve as discussões para o terreno pessoal (...)"; (2) "fale livremente (...), porém, manifeste-se apenas quando chegar a sua vez"; (3) "respeite as regras [para] o sucesso de todo o debate". (CEREJA; MAGALHÃES, 2013a, p. 332). Tais orientações podem favorecer uma reflexão sobre a tomada de posição no interior da situação comunicativa se forem bem conduzidas pelo docente.

O terceiro aspecto do quadro foca na "expressão", ou seja, no modo como o aluno deve utilizar seu corpo para "dizer" algo mais. Assim, ao falar sobre o olhar e as gesticulações, a obra alerta que o olhar direto "passará impressão de firmeza e segurança" e as excessivas gesticulações podem "distrair a atenção dos ouvintes". Além disso, há ainda indicações quanto ao tom de voz ("fale alto, de modo claro e articulado") e à postura durante leituras que se fizerem necessárias ("se fizer uso de anotações durante a fala, leia-as de forma rápida e sutil, sem interromper o fluxo da fala e do pensamento. Evite abaixar a cabeça e o tom da fala."). Todas essas orientações (CEREJA; MAGALHÃES, 2013a, p. 332) evidenciam uma preocupação acerca de uma entonação expressiva, conduzindo a uma reflexão pertinente para o gênero trabalhado.

O diálogo com a teoria dialógica do discurso, declarado no MP, mantém-se na condução da proposta, fazendo ecoar uma voz da ciência da linguagem que consolida a validade da atividade. Ele entra, pois, como um discurso internamente persuasivo (BRASIL, 1930-36/2015). 
Por fim, no último aspecto apresentado no quadro, o enfoque recai sobre aspectos linguísticos.

Uso da língua

- Use a norma culta, menos ou mais formal, de acordo com o perfil dos participantes.

- Evite o uso reiterado de palavras e expressões como né?, tipo, tipo assim, etc, pois atrapalham o fluxo das ideias e dispersam a atenção dos ouvintes.

- Faça referência à fala de outro debatedor, com expressões como Conforme disse fulano..., Concordo com a opinião de fulano..., Discordo em parte do ponto de vista de fulano..., Gostaria de acrescentar ao comentário de fulano que...

Fonte: CEREJA; MAGALHÃES, 2013a, p. 332.

Essa orientação evidencia, por um lado, uma preocupação com o uso linguístico focado no interlocutor ("perfil dos participantes") e, por outro, com recursos de coesão importantes para refutar/validar argumentos dados pelo "oponente".

Apesar de as indicações apresentadas serem significativas, mais uma vez será fundamental o trabalho do professor para validá-las no interior do evento, seja por propor uma atividade de análise de um debate real, seja por discutir de maneira contextualizada as indicações apresentadas.

O quadro, apresentado de forma estanque, pode levar o aluno à ideia de que os debates sempre ocorrem da mesma forma, independente da esfera em que ele acontece.

Assim, o aluno não é levado a perceber que a forma de organização do gênero é importante, mas apenas se este for considerado no interior da esfera de que ele participa, ocasião em que de fato ganha seu acabamento. Nada mais distante do pensamento bakhtiniano que propostas que visem apenas o reconhecimento de estruturas dos textos ou de suas formas de linguagem características, sem relacionar essas escolhas com o campo efetivo de sua produção, recepção e circulação.

As OCEM (BRASIL, 2006, p. 37) defendem a necessidade de se "promover um ambiente profícuo à discussão" e, nesse sentido, a atividade é validada, pois traz indicações que dão condições para a realização adequada do debate. 
Após a apresentação do quadro esquemático no livro didático, o aluno é orientado a filmar o debate a fim de observar, posteriormente, o que ficou adequado e o que ainda precisa melhorar. Os critérios para isso, apresentados na subseção "Revisão e avaliação" retomam o quadro dado para leitura antes do debate.

Depois de realizado o debate, avaliem-no, levando em conta as orientações apresentadas no quadro 'Planejamento do debate regrado público'. Verifiquem:

- Se houve respeito às regras estabelecidas;

- Se o moderador cumpriu bem o seu papel de coordenador;

- Se o tempo foi respeitado;

- Se houve riqueza de ideias e argumentos;

- Se o desempenho dos participantes foi bom;

- Se houve respeito entre os participantes;

- Se a linguagem empregada pelos participantes seguiu a norma-padrão informal;

- Se houve ou não na fala dos participantes certos vícios de linguagem, como "tipo", "tipo assim", "tá ligado", entre outros.

Se necessário, assistam novamente a alguns trechos do debate gravado para observar detalhes, confirmar impressões ou tirar dúvidas. Ao final, estabeleçam metas e compromissos com vistas à realização do próximo debate.

(CEREJA; MAGALHÃES, 2013a, p. 333. Grifo nosso.)

Apesar de serem relevantes atividades de análise da linguagem oral, a proposta deixa para o professor decidir se o vídeo será ou não assistido de fato, visto que isso deve ser feito "se necessário", como apresentado na comanda final do enunciado transcrito.

Essa atividade de análise seria fundamental para o aluno pensar sobre a questão da valoração do enunciado, observável não apenas no conteúdo do que é dito, mas reconhecível pelas escolhas linguísticas empreendidas pelo enunciador, bem como pela forma que dá ao seu discurso. Em outras palavras, a reflexão sobre o debate produzido pelos alunos poderia ajudá-los a perceber que tanto o estilo, quanto a forma composicional evidenciam um juízo de valor, um posicionamento do sujeito em relação ao dito. Exatamente o que sentimos falta na proposta ao apresentar tópicos que devem ser seguidos, sem se considerar a singularidade do evento.

No vol. 3, há uma proposta de debate na primeira metade do capítulo 3 , da unidade 3 , mas com o foco direcionado para os aspectos argumentativos, o que 
pode ser observado logo no título do capítulo: "O debate regrado público: estratégias de contra-argumentação". Nas oito páginas da proposta didática, observamos a seguinte organização interna:

Tabela 22 - Organização cap. Debate regrado público - col.1-PL

\begin{tabular}{|c|c|c|}
\hline \multicolumn{3}{|c|}{ Capítulo 3 - 0 debate regrado público: estratégias de contra-argumentação } \\
\hline 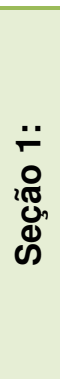 & "Trabalhando o gênero" & $\begin{array}{l}\text { Propostas: } \\
\text { - Leitura de parágrafos introdutórios que relembram que o } \\
\text { gênero foi estudado no vol.1 e enfocam o que será estudado } \\
\text { no vol.3. } \\
\text { - Leitura de dois artigos de opinião. } \\
\text { - Perguntas sobre o texto (focadas em questões ligadas à } \\
\text { argumentação). } \\
\text { - Leitura de tópicos sobre "Estratégias de contra- } \\
\text { argumentação". }\end{array}$ \\
\hline & $\begin{array}{l}\text { "Produzindo o debate } \\
\text { regrado público" }\end{array}$ & $\begin{array}{l}\text { Propostas: } \\
\text { - Leitura: Artigo de opinião sobre pessoas com deficiência } \\
\text { - física. } \\
\text { Orientação para a produção: duas questões norteadoras } \\
\text { para o debate sobre "cotas para pessoas com deficiência no } \\
\text { serviço público". } \\
\text { - Planejamento: leitura do mesmo quadro do vol.1, com } \\
\text { orientações sobre como preparar a sala, e sobre o papel do } \\
\text { moderador e dos debatedores. } \\
\text { - Filmagem: solicitação para que o debate seja filmado para } \\
\text { posterior análise. } \\
\text { - Revisão e avaliação: tendo como base o quadro } \\
\text { apresentado no momento de "Planejamento". }\end{array}$ \\
\hline
\end{tabular}

Fonte: CEREJA e MAGALHÃES, 2013c. p. 251-258.

A estrutura do capítulo é semelhante ao observado no vol.1: há duas seções, uma que pretende trabalhar o gênero e a outra orientar sua produção.

$\mathrm{Na}$ seção Trabalhando o gênero, o parágrafo introdutório do capítulo esclarece o objetivo das leituras que serão realizadas em seguida: "observar de que modo são construídos e apresentados os argumentos utilizados em debates" (CEREJA; MAGALHÃES, 2013c, p. 251)

Os textos apresentados em seguida são artigos de opinião que enfocam a questão das cotas raciais, trazendo uma visão favorável ("Cotas enriquecem universidades") ou contrária ("Cota valida teses racistas") à causa. (CEREJA; MAGALHÃES, 2013c, p. 252 e 253) 
As leituras propostas dão base ao aluno para orientá-lo, tematicamente, em relação ao debate de opinião que será realizado posteriormente. Funcionam também como um discurso internamente persuasivo, pois retoma as vozes de especialistas que tratam sobre $o$ assunto.

Considerando as diferentes visões apresentadas pelos textos, entendemos que os alunos terão oportunidade para se colocar como autores do próprio discurso, visto não ser essa uma proposta direcionada, como observamos no vol.1. Ao tomar contato com posições divergentes, o aluno tem a possibilidade de desenvolver seu posicionamento crítico, evidenciando sua voz autoral em relação ao tema proposto.

As questões apresentadas após a leitura têm como finalidade levar os alunos a observarem os argumentos utilizados por cada autor dos textos, estratégia que vai ao encontro do objetivo declarado no início do capítulo.

6. Nos textos argumentativos, é comum a utilização de diferentes tipos de argumento para fundamentar o ponto de vista defendido: exemplos, citações de pessoas ilustres, comparações, referências históricas, estatísticas, etc. Desses tipos de argumento, quais são utilizados:

a) no texto de José Roberto Ferreira Militão?

b) no texto de Hédio Silva Jr.?

(CEREJA; MAGALHÃES, 2013c, p. 254)

Em seguida, a obra apresenta seis tópicos para ensinar o aluno a contraargumentar, os quais podem ser assim sintetizados: (1) descobrir incoerências e contradições e usar isso a seu favor; (2) desconstruir um argumento apresentado como "verdade irrefutável" com dados e informações concretas (estatísticas, pesquisas, exemplos históricos...); (3) mostrar - a partir de casos reais e específicos - que argumentos generalizantes são discutíveis; (4) examinar o sentido das palavras utilizadas pelo adversário e verificar se não há alguma expressão que pode ser rediscutida; (5) realizar sínteses dos argumentos do outro e compará-los com os que foram apresentados por você, a fim de mostrar a pertinência de um argumento sobre o outro; (6) fazer concessões, admitindo que o outro tem razão, ainda que parcialmente, a fim de favorecer uma posição intermediária entre as ideias divergentes. 
Todas as orientações (CEREJA; MAGALHÃES, 2013c, p. 255) trazidas neste volume são relevantes e evidenciam uma progressão, como defendido pelos estudos dos pesquisadores de Genebra (SCHNEUWLY e DOLZ, et al, 2004) para o ensino do gênero, visto que amplia a abordagem proposta no vol.1, no que tange à discussão sobre os recursos de argumentação.

Entendemos, no entanto, que a voz do professor será fundamental para levar o aluno a relacionar os pontos levantados teoricamente com situações reais de interação, trazendo assim a singularidade do evento para dialogar com cada uma das estratégias apresentadas.

$\mathrm{Na}$ segunda parte do capítulo, na seção "Produzindo o debate regrado público", o texto de leitura proposto não está ligado à questão de cotas diretamente. É uma reflexão acerca da importância de se aceitar como somos: "Projetar aquilo que a gente não é pode ajudar a valorizar, a dar carinho, àquilo que a gente de fato é" (CEREJA; MAGALHÃES, 2013c, p. 256). Dessa forma, o texto de leitura, embora cite as pessoas com deficiência ao longo da discussão, não influencia, de maneira direta, na discussão proposta para o debate apresentado. $O$ discurso citado funciona, assim, como internamente persuasivo e contribui para a reflexão do aluno:

Debata com os colegas da classe:

- Na sua opinião, devem existir cotas para o ingresso de pessoas com deficiência no serviço público e em empresas privadas?

- O que você acha da política de inclusão em escolas comuns, isto é, não especializadas, de pessoas com deficiência?

(CEREJA; MAGALHÃES, 2013c, p. 257)

Em seguida, na subseção Planejamento do debate regrado público, o aluno entrará em contato com o quadro já apresentado no vol. 1, com as mesmas informações sobre a preparação da sala, as atribuições do moderador e dos debatedores, bem como indicações de controle do tempo.

A alteração é apenas no layout do quadro (azul no volume 1 e colorido no vol.3) e no título que ele tem no volume 1 ("Planejamento do debate regrado público") e no volume 3 ("Princípios e procedimentos para a realização de um debate democrático"). 
Figura 9 - Orientações para o planejamento do debate - Col.1-PL-vol.3

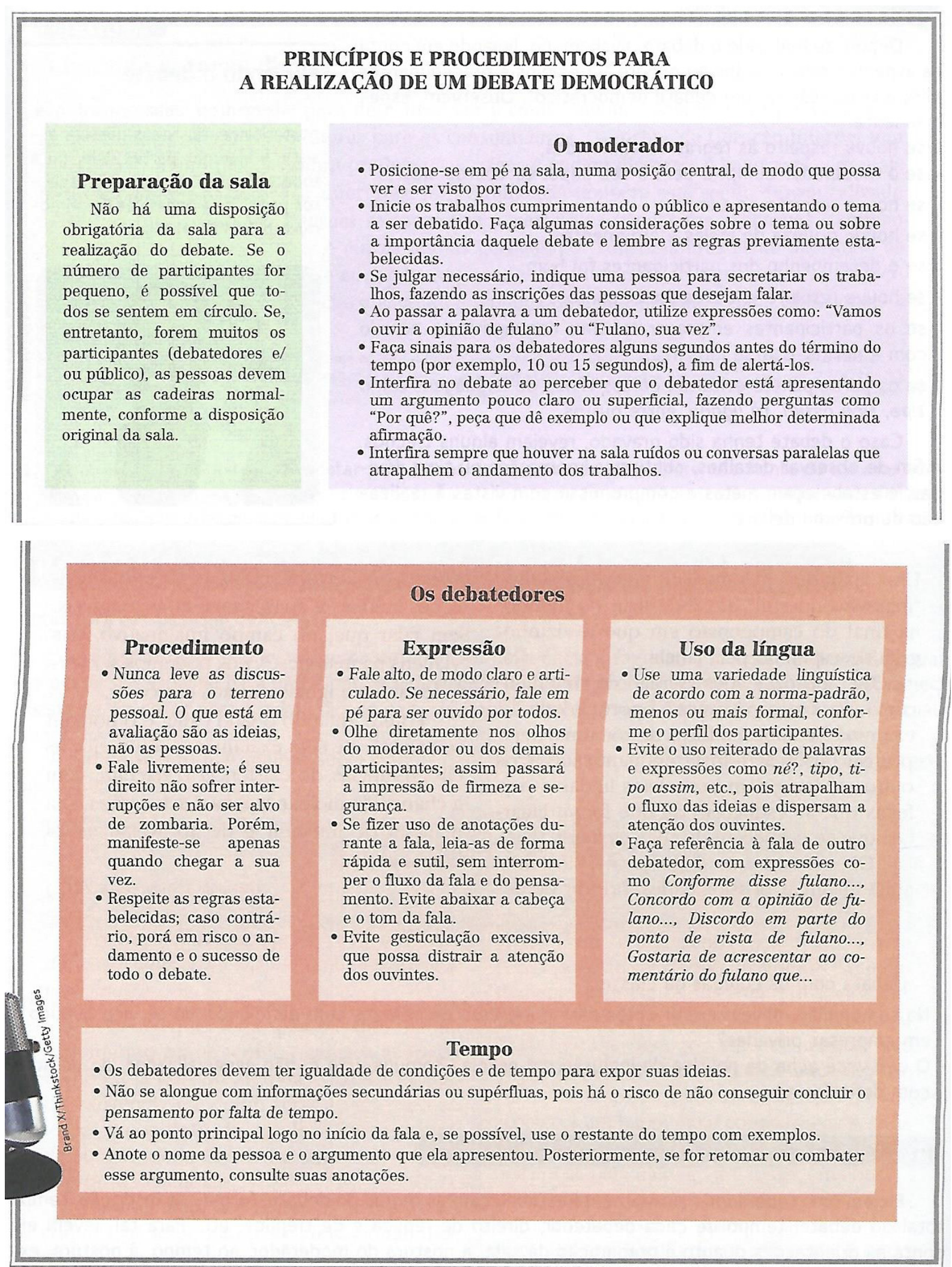

(CEREJA; MAGALHÃES, 2013c, p. 257 e 258) 
Essa proposta didática encerra-se, assim como no vol. 1, com a subseção "Revisão e avaliação", ocasião em que, mais uma vez, os tópicos levantados para verificação do debate retomam os aspectos apontados no quadro apresentado anteriormente e cuja redação é exatamente a mesma do que foi apresentado no primeiro volume da coleção.

No que tange à orientação para que o debate seja filmado - parágrafo também igual ao do vol.1 - observamos, mais uma vez, que esta ação é situada no plano da sugestão, ficando facultativa sua realização: "caso o debate tenha sido gravado, revejam alguns trechos, a fim de observar detalhes, confirmar impressões ou tirar dúvidas, e estabeleçam metas e compromissos com vistas à realização do próximo debate." (CEREJA; MAGALHÃES, 2013c, p. 258).

A proposta de debate nesse capítulo, portanto, retoma muitos aspectos já observados pelo aluno no primeiro volume, acrescenta orientações sobre formas de contra-argumentar, mas ainda não focaliza o uso da análise de um debate real para ampliar a discussão acerca das características orais ligadas ao gênero.

Os dois outros momentos em que a realização de um debate está orientada no vol. 3 refere-se uma indicação procedimental, no interior de várias ações a serem realizadas na seção "Projeto".

A primeira delas (vol.3, unid. 2, cap. 10- Competências e habilidades do Enem I) refere-se a um debate que deve ser realizado após os alunos assistirem a um vídeo intitulado "Depoimento de Antônio Cândido no Simpósio Graciliano Ramos - 75 anos do livro 'Angústia'”.

A atividade orienta:

Visto o vídeo, promovam um debate com os professores e com o público, tentando abordar as seguintes questões, entre outras:

- Por que os anos 1930 marcam um momento de mudança profunda no quadro político brasileiro?

- Qual a importância do rádio e da música popular brasileira para a transformação dos costumes na década de 1930 ?

- Por que o romance de 1930 pode ser visto como um romance de descoberta, responsável pela unificação do Brasil?

- Que novidades o romance de 1930 trazia em relação ao retrato do Brasil?

- Por que, na visão de Antonio Candido, Graciliano Ramos era o principal expoente entre os romancistas de 1930?

(CEREJA; MAGALHÃES, 2013c, p. 225). 
Considerando que a discussão está ligada a tema da esfera do conhecimento, percebemos que a orientação aqui posta assemelha-se ao que os pesquisadores genebrinos (DOLZ, SCHNEUWLY, DE PIETRO, 2004) definem como "debate para resolução de problemas", enquanto que os dois debates analisados nesse capítulo estão mais ligados a um "debate de opinião de fundo controverso".

Outra diferença pode ser observada nesta atividade em relação às demais: o gênero debate aqui não é tomado como objeto de ensino, mas visto como uma prática social, já que, no interior da situação didática apresentada, ele será um instrumento que oportuniza a discussão para a realização de uma mostra cultural, ao final do projeto.

Por fim, na última atividade de debate da coleção, localizada no interior da seção "Projeto" (vol. 3, unid. 3, cap. 8- Competências e habilidades do Enem II) , o tema apresentado é sobre o uso positivo ou negativo da internet, evidenciando, assim, a proposição de um debate de opinião de fundo controverso (DOLZ, SCHNEUWLY, DE PIETRO, 2004).

As orientações sobre o que fazer passam pelas seguintes etapas: (1) conhecimento do tema que será debatido; (2) definição sobre quem serão os participantes (alunos, professores, pais de alunos, profissionais do bairro etc.), moderador e quais serão as regras do debate; (3) definição de como o evento será divulgado, onde será realizado; (4) orientação para que seja filmado. (CEREJA; MAGALHÃES, 2013c, p. 295)

A proposta focaliza menos o passo-a-passo de construção do gênero e mais o seu uso real, ocasião em que o aluno terá a oportunidade de utilizar o que aprendeu nos capítulos dedicados à reflexão mais pontual sobre a construção do debate. Assim, o debate é tratado como uma prática social.

Considerando o objetivo da proposta, entendemos que esta é uma situação relevante que permitirá ao aluno colocar-se e apresentar seu posicionamento valorativo a partir de tudo o que foi aprendido ao longo do volume.

Para esta coleção, portanto, observamos que o debate de opinião de fundo controverso é proposto em três momentos, dois em que o gênero é tomado como objeto de ensino - e em que se observa uma progressão - e outro em que ele está presente como uma prática social, no interior de um projeto da unidade. Como 
debate para resolução de problemas, a coleção apresenta uma proposta que também funciona como recurso para que o aluno faça uso do gênero estudado, no interior de uma situação concreta de comunicação.

Quanto à condução das propostas, considerando que as orientações são dadas de forma expositiva e que as indicações de análises de debates gravados ficam no nível da sugestão, a ação do professor, no interior do acontecimento, ganha uma dimensão maior, visto que dependerá dele a tomada de posição para sanar as ausências que não puderam ser resolvidas no livro didático analisado.

O diálogo estabelecido tanto com o Edital, quanto com as OCEM também ficou marcado na proposta tanto por "contribuir para a ampliação de conhecimentos dos alunos" (BRASIL, 2006, p. 37), quanto por atender ao que é exposto oficialmente pelo MEC (BRASIL, 2013b)

\subsection{O debate e o vínculo com a literatura em Novas palavras}

A orientação para produção textual - no caderno Redação e leitura - está organizada, na coleção Novas palavras (col.2-NP), por tipos textuais. Por esse motivo, não há um capítulo na íntegra em que o gênero debate seja explorado de forma extensiva.

Para os autores da coleção, é a combinação das tipologias textuais em sequências que resultaria em gêneros:

(...) trabalhamos as modalidades clássicas de textos - a descrição, a narração, a dissertação - num contexto dialógico, ou seja, progressivamente explorando como se articulam em sequências cujas combinações resultam nos gêneros textuais.

(AMARAL et al, 2013a, p. 16 do MP)

O trabalho com o gênero debate é organizado, assim, no interior da seção "E mais", cujo objetivo, segundo o MP, é propor discussões orais que serão "pontes para as atividades de produção" (AMARAL et al, 2013a, p. 17 do MP). Há, ao longo dos três volumes, dezesseis momentos em que esta seção faz alusão ao debate. 
Tabela 23: Títulos da seção "E mais" - gênero "debate" - Col.2-NP

\begin{tabular}{|c|c|c|c|}
\hline $\begin{array}{c}\text { Divisão da } \\
\text { obra }\end{array}$ & Vol.1 & Vol.2 & Vol.3 \\
\hline Literatura & $\begin{array}{l}\text { Discussão } \\
\text { (p.31-32) } \\
\text { Debate (p.108) }\end{array}$ & $\begin{array}{l}\text { Leitura e debate } \\
\text { (p.157-158) }\end{array}$ & $\begin{array}{l}\text { Debate interdisciplinar: a } \\
\text { atualidade do problema dos "dois } \\
\text { Brasis" (p.21) } \\
\text { Debate interdisciplinar ( } p .38) \\
\text { Debate e pesquisa (p.50) } \\
\text { Pesquisa (p.68-69) } \\
\text { Dramatização e debate (p.86-88) } \\
\text { Debate (p.120) } \\
\text { Debate (p.167) }\end{array}$ \\
\hline Gramática & ---- & ---- & ---- \\
\hline $\begin{array}{l}\text { Redação e } \\
\text { leitura }\end{array}$ & Debate (p.326) & $\begin{array}{l}\text { "Sem título" (p.324-325) } \\
\text { Debate (p.389) }\end{array}$ & $\begin{array}{l}\text { Proposta e debate (p.314-315) } \\
\text { Debate (p. 343) } \\
\text { Debate regrado (p.379-380) }\end{array}$ \\
\hline
\end{tabular}

Fonte: AMARAL et al, 2013d.

As propostas de debate estão concentradas, em sua maioria, no volume $3 \mathrm{e}$ ocorrem, em grande parte, ligadas ao eixo de Literatura. A distribuição delas ao longo da obra permite observar que esse gênero não é solicitado no interior do caderno Gramática.

Quanto à disposição da seção "E mais", não há um lugar regular em que pode ser encontrada, ou seja, no caderno Literatura, ela está distribuída ao longo do capítulo, ora após uma seção de leitura, ora após a seção de releitura; no caderno Redação e leitura, ela pode aparecer tanto ao longo do capítulo, após uma atividade ou orientação de produção textual, quanto ao final dele, como encerramento da proposta apresentada. Ela foi disponibilizada, portanto, sempre que os autores entenderam que havia uma oportunidade de diálogo oral. Isso permitiu, por exemplo, que houvesse mais de duas dessas seções em um só capítulo ou que, eventualmente, esta seção não aparecesse.

No volume 1, o debate é citado em três momentos: em dois capítulos (2 e 8) do caderno Literatura e em um (cap. 2) do caderno Redação e leitura. 
A primeira proposta (Caderno Literatura, cap. 2- O texto literário) é dada após a leitura do conto Majestic Hotel, de Sérgio Faraco.

\section{Figura 10: Proposta de debate (início) - Col.2-NP}

\section{mais...}

\section{Discussão}

Reúna-se com seu grupo e prepare a discussão sobre o conto de Sergio Faraco.

Apresentamos alguns tópicos a serem discutidos, mas você deve propor outros, sobretudo formular suas dúvidas para que os colegas o ajudem a resolvê-las.

a) Reflita sobre o foco narrativo do conto e responda: é o personagem que narra os acontecimentos passados no Hotel Majestic? Classifique o foco narrativo e explique.

b) Leia, no quadro ao lado, as definiçóes dos termos memória, lembrança, recordação, reminiscência. Determine e explique qual seria a melhor classificação dos pensamentos do personagem do conto sobre os acontecimentos do passado.

c) Embora o narrador se atenha às lembranças fragmentárias do menino, podemos adivinhar, sugerida nas entrelinhas, uma outra história, não contada. Observando os índices espalhados pelo texto, reconstitua essa história subentendida.

Terminado o prazo para a preparação, o professor estabelecerá as regras para a discussão geral entre os grupos.

Memória - faculdade
de conservar e
experimentar de novo
estados de consciência
passados.
Lembrança - resultado
do exercício da
memória; apresentação,
pela memória, de ideias
adquiridas.
Recordação -
lembrança reavivada;
ato de trazer à
lembrança as ideias
confiadas à memória.
Reminiscência -
lembrança inconsciente,
vaga, impressão ligeira
que ficou de coisa lida,
ouvida, vista, de ideias
e noções que foram
presentes em tempos
remotos.
Fonte de pesquisa:
NAscENTEs, Antenor.
Dicionário de sinônimos.
3. ed. Rio de Janeiro: Nova
Fronteira, 1981.p. 3a3.

(AMARAL et al, 2013a, p. 31)

A orientação dessa primeira atividade gira em torno do levantamento do foco narrativo do texto, classificação dos pensamentos da personagem e reconstituição da história subentendida nas entrelinhas do conto. A proposta, portanto, está ligada a uma análise de elementos da narrativa e aos alunos é dada a oportunidade de apresentar oralmente suas respostas aos demais colegas e ouvir o que eles colocaram. É uma atividade que, embora oral, não oportuniza, a nosso ver, o debate de fato, uma vez que o tema de "discussão" está mais ligado a uma categorização dos pensamentos das personagens (memória, lembrança, recordação ou reminiscência?), mas, a partir dessa informação, nada mais é proposto, o que daria fim ao "debate".

Considerando que o subtítulo da seção é "Discussão", inicialmente descartamos esta proposta para análise. No entanto, na página seguinte, há uma orientação quanto aos procedimentos para que esse "debate" ocorra. Dessa forma, 
como a palavra "debate" foi mencionada, entendemos que seria relevante analisar mais de perto a atividade.

Figura 11: Proposta de debate (continuação) - Col.2-NP

\section{Procedimentos}

Para que um debate tenha bons resultados, os participantes devem:

- falar com clareza e objetividade;

- ouvir os colegas com atenção e respeito:

- buscar argumentos convincentes;

- saber reconhecer a validade dos argumentos dos outros debatedores.

Não se deve confundir "debate" com "combate". O objetivo nåo é "sair vencedor", mas colaborar para um resultado comum (neste caso, o aprofundamento da compreensão e da interpretação do texto lido).

(AMARAL et al, 2013a, p. 32)

O enfoque apresentado gira em torno de ações a serem realizadas no momento de interação: falar, ouvir, argumentar. No entanto, a obra explicita que o objetivo da atividade é realizar um "aprofundamento da compreensão e da interpretação do texto lido", como pode ser observado no interior dos parênteses, na citação acima.

Ao usar duas terminologias diferentes - ora "discussão", ora "debate" - a obra parece, na condução da proposta, não dar clareza quanto ao que se está considerando debate.

No nosso entender, atividades de discussão estão mais ligadas a um exame minucioso de um assunto ou problema, e é possível apresentar um ponto de vista, mas não, necessariamente, defendê-lo com argumentos, de forma sistemática. No debate, a análise realizada é mais detalhada e pode até demandar pesquisa ou outras leituras. Além disso, nele há, obrigatoriamente, a defesa de um ponto de vista, ocasião em que a seleção dos argumentos será significativa para a finalidade que se deseja alcançar. Daí ser relevante considerar-se não apenas sobre o que falar, mas se esse tema é polêmico, ou seja, se permite a defesa de uma opinião. 
Na obra didática analisada há diversas ocasiões em que a seção "E mais" aparece com o subtítulo "Discussão". Nestes momentos, é possível observar como a questão do tema proposto pode diferenciar uma discussão de um debate. Seguem dois exemplos, um do volume 1 e outro do volume 3 , respectivamente:

Discussão

O grupo deve discutir as questões propostas e indicar dois alunos para apresentar as conclusões à classe, seguindo as orientações do professor.

1. No texto "Pausa", (cap. 1, p. 17), Mário Quintana afirma ter duas personalidades, identificadas como Dom Quixote e Sancho Pança; a crônica que você acaba de ler personifica, no Preto e no Branco, os dois lados de um autor. Discuta com seus colegas: que cor - branca ou preta - se deve atribuir a Dom Quixote? E a Sancho Pança? Por quê?

2. Por que o texto "Preto e Branco" pode ser considerado uma paródia de uma peça teatral?

(AMARAL et al, 2013a, p. 36, grifo nosso.)

Discussão

Leia atentamente o fragmento a seguir e discuta com seus colegas as questões propostas.

[Leitura de um parágrafo de uma entrevista que Guimarães Rosa concedeu a Günter Lorenz]

1. O que há de comum entre o sertão de Guimarães Rosa e o "lugarzinho" do texto de Mia Couto? [romance "Terra sonâmbula", fragmento lido antes pelos alunos]

2. Nos dois textos, quem são os contadores de estórias, para quem elas são contadas e qual é a sua função na vida dos indivíduos? Escolha um pequeno trecho de cada texto para ilustrar sua resposta.

(AMARAL et al, 2013c, p. 156-157, grifo nosso.)

No enunciado das citações é possível observar a sentença "Discuta com seus colegas", bastante comum em propostas didáticas desse tipo. Além disso, o tema está ligado a uma reflexão acerca das leituras realizadas e permite uma troca de opiniões, mas não carece de defesa sistemática, com uso de argumentos mais concretos. São válidas, por exemplo, as impressões do aluno.

O segundo momento em que há uma orientação para realização de debate no volume 1 (caderno Literatura, cap. 8- O Barroco brasileiro), observamos a presença de uma proposta que se aproxima do debate de opinião de fundo controverso (DOLZ, SCHNEUWLY, DE PIETRO, 2004). 
A partir da leitura do "Sermão do bom ladrão", de Padre Vieira, os alunos devem debater sobre: atualidade do tema tratado no sermão, relação entre roubo, necessidade e corrupção e, por fim, estratégias para combatê-la.

\section{Debate}

O texto que você acabou de ler é o registro de um sermão pronunciado numa igreja - Capela da Misericórdia de Lisboa - há mais de 350 anos.

O professor estabelecerá as regras e organizará um debate sobre os seguintes temas:

- $\quad$ Atualidade do texto

- O tema do "Sermão do bom ladrão" ainda é atual? Por quê?

- A argumentação do autor seria válida para o Brasil do século XXI?

Que fatos noticiados nos últimos anos pela imprensa podem justificar a opinião do grupo?

- " [...] a mesma miséria ou escusa ou alivia o seu pecado"

- O roubo motivado por necessidade (fome, miséria, exclusão social)

é justificável?

- O roubo e a corrupção dos ladrões de "maior calibre" (políticos, empresários) justificam o roubo dos ladrões de "menor calibre"?

- "Ditosa Grécia, que tinha tal pregador!"

- As denúncias da imprensa e de outras instituições são eficazes no combate à corrupção? O cidadão comum tem algum papel no combate à corrupção? Se tem, que ações ele pode desenvolver?

Preparação

Cada grupo deverá:

- $\quad$ Preparar os argumentos para defender a posição, afirmativa ou negativa, em relação às questões propostas sobre o tema;

- Escolher um debatedor, que representará os colegas e receberá a assistência deles durante a discussão.

(AMARAL et al, 2013a, p. 108)

Para tratar do primeiro tema - atualidade do sermão - o aluno não poderá limitar-se a dizer sua opinião (é atual / não é atual), mas terá que fazer leituras e pesquisas para comprovar seu posicionamento. Além disso, precisará retomar o texto-fonte para discutir se as argumentações utilizadas por Vieira seriam válidas para o século XXI. Nesse aspecto, observamos que essa atividade permite ao aluno apresentar sua voz, colocando-se em relação ao dito para, efetivamente, posicionarse. 
Os dois outros temas sugeridos na atividade giram em torno de questões éticas ao estimular uma reflexão sobre roubo, corrupção e ações para seu combate. Mais uma vez, o aluno terá que se preparar para defender seu ponto de vista e, por se tratar de um tema polêmico, terá possibilidades para desenvolver seu discurso autoral em situação oral de interação. Observa-se, portanto, que a proposta permite ao aluno o desenvolvimento de sua voz.

A partir dessa análise, podemos retomar também a distinção entre "discussão" e "debate", sobre a qual tratamos anteriormente. O diálogo proposto a partir dos três temas evidencia um movimento que demanda o desenvolvimento de diversas capacidades, por exemplo: estabelecer relações, generalizar, concluir, aplicar o conhecimento adquirido a um novo contexto. Todos esses aspectos diferenciam essa proposta de uma simples "discussão", visto que extrapolam a simples troca de opinião baseada em ponto de vistas subjetivos.

No que tange à explicitação, para o aluno, do processo de interação em que ocorre o debate, a obra parece ter como pressuposto que este já tem domínio do gênero e, portanto, já conhece como ele deve ser realizado, visto que a única indicação dada é para o grupo "escolher um debatedor (...) [para] a discussão" (AMARAL et al, 2013a, p. 108). Não há, também no MP, orientações que possam ampliar essa visão do momento de produção do gênero, no sentido de levar o aluno a perceber as singularidades do evento, para estar atento, por exemplo, à escolha da linguagem mais adequada aos interlocutores envolvidos e à formalidade (ou não) da situação. Caberá ao professor, assumir sua voz e preencher, assim, essas lacunas.

O terceiro (e último) momento, no volume 1 , em que o debate é indicado como atividade a ser realizada pelo aluno ocorre no caderno Redação e leitura (capítulo 2- Linguagens: entre textos, entre linhas), após uma orientação de produção textual que se divide em duas etapas: (1) narração de um encontro entre dois jovens que se conheceram pela internet; (2) leitura de um quadro sobre os perfis de jovens que gostam de consumir. A proposta do debate está relacionada a essa leitura. 


\section{Debate}

Tema: A relação entre os jovens e o consumo na sociedade contemporânea.

Roteiro

1. Preparação: reúna-se com seu grupo e discuta os seguintes pontos:

$1^{\circ}$ momento: enumerem os aspectos positivos e negativos da relação entre os jovens e o consumo.

$2^{\circ}$ momento: justifiquem tais aspectos, a partir da avaliação de experiências vivenciadas, explicando por quais razões concretas uns aspectos são positivos e outros são negativos.

3o momento: cheguem a um consenso sobre um aspecto positivo e um aspecto negativo do consumo.

2. Resumo: anotem as conclusões a que o grupo chegou.

3. Discussão: os grupos reúnem-se para uma discussão mais ampla, apresentando em plenário as conclusões da discussão, a fim de ampliá-la com a contribuição dos aspectos levantados por todos os grupos.

(AMARAL et al, 2013a, p. 326. Grifo nosso.)

A condução da atividade ocorre a partir de uma orientação temática que visa a uma tomada de decisão em relação a qual seriam os aspectos positivos e negativos do consumo. Considerando que os alunos devem chegar a um "consenso", evidenciando uma escolha única do grupo do "positivo" e do "negativo", entendemos que este é um debate deliberativo (DOLZ, SCHNEUWLY, DE PIETRO, 2004).

No que tange à tomada de posição do aluno, observamos que o tema proposto permite o desenvolvimento da voz discente, visto ser polêmico e pertinente à idade dos jovens do ensino médio. $O$ aluno não é solicitado $a$, meramente, reproduzir um discurso previamente dado, mas terá que, após leituras e análises de situações concretas, explicitar seu posicionamento e defendê-lo perante seus pares com o uso de argumentos pertinentes.

Considerando a ausência de orientações mais pontuais para o momento de interlocução, será papel do professor, na singularidade do ato, propiciar ao aluno reflexões mais amplas ligadas à esfera de produção, circulação e recepção do gênero. Mais uma vez, a voz do docente terá que se fazer ouvir. 
No volume 2, a menção ao gênero debate, no interior da seção "E mais", aparece em três momentos: no caderno Literatura (capítulo 8) e no caderno Redação e leitura (capítulos 2 e 8).

No primeiro (caderno Literatura, cap. 8- Simbolismo em Portugal), a proposta está localizada no início do capítulo, após a seção Releitura. A orientação dada ao aluno é a leitura da nota preliminar da obra "Mensagem", de Fernando Pessoa, a qual trata das "qualidades do intérprete". Seguem-se ao texto algumas questões e é a resposta oral compartilhada destas que a obra entende como "debate".

\section{Leitura e debate}

Leia a nota preliminar de Mensagem, de Fernando Pessoa, um dos maiores poetas da língua portuguesa, e discuta com os colegas as questões apresentadas.

[TEXTO “NOTA PRELIMINAR"]

Entre as qualidades do intérprete, descritas por Fernando Pessoa:

a) com qual(is) você se identifica?

b) qual(is) Ihe parece $(\mathrm{m})$ mais difícil(eis) de adquirir? Por quê?

c) qual(is) pode (m) ser associada(s) à estética:

* romântica * realista * simbolista

(AMARAL et al, 2013b, p. 157-158. Grifo nosso.)

A atividade em questão não propicia um debate e está mais ligada ao desenvolvimento da capacidade leitora (apreciação estética e comparação) e menos a uma interlocução voltada para defesa de opinião baseada em fatos.

Parece haver aqui também uma confusão entre o "debate", mencionado no título, e a "discussão", que é o que de fato é orientado no enunciado, conforme destacamos.

A segunda proposta de debate do volume 2 ocorre no interior do caderno de Redação e leitura, capítulo 2, intitulado "O diário pessoal", após o boxe "Navegar é preciso". Neste, o aluno é orientado a assistir ao filme "Vida de menina" e a ler o livro "Minha vida de menina", de Helena Morley. Como o livro trata de um diário pessoal real de uma jovem que, nas entrelinhas de seu relato, deixa transparecer um pouco da história de sua época, a seção "E mais" traz uma proposta interdisciplinar para que se faça um debate "sobre a importância do período de grande exploração 
mineradora no Brasil, que ocorreu ao longo do século XVIII." (AMARAL et al, 2013b, p. 325).

Além da indicação temática, não há outra orientação para a realização do debate. Ele é, portanto, tratado como uma prática social, permitindo ao aluno interligar conhecimentos de várias áreas: Filosofia, História, Geografia e Português.

No que tange à tomada de voz do aluno, preocupa-nos que este, após realizar suas pesquisas, apenas reproduza o discurso de seus estudos e não consiga se colocar frente a ele. Dessa forma, entendemos que o professor terá um importante papel para organizar esse momento de interação a fim de realmente estimular o debate. Caso contrário, a voz do aluno poderá ser silenciada.

A terceira proposta de debate, para encerrar o volume 2, está presente no final do capítulo 8, intitulado "A dissertação" e traz a seguinte comanda inicial: "Uma nova questão tem merecido a atenção de profissionais envolvidos com a educação de adolescentes: a adaptação de clássicos da literatura para o cinema ou para os quadrinhos forma ou deforma os futuros leitores?" (AMARAL et al, 2013b, p. 389).

A atividade não tem relação temática com o que foi solicitado no boxe "Navegar é preciso", que precede a orientação do debate sobre a questão das adaptações. No entanto, o referido boxe pode ser bastante útil para ampliar as discussões acerca do gênero, visto que o aluno é orientado a assistir a um debate de telejornal para analisar tanto pontos de vista e argumentos, quanto o papel do mediador.

Figura 12: Boxe com orientação prévia ao debate - Col.2-NP

$$
\text { Navegar é preciso }
$$

Assista a um debate, apresentado em um telejornal da TV Cultura, um exemplo de discussão sobre um tema polêmico: o uso de células-tronco embrionárias em pesquisas científicas. Preste atenção na postura dos debatedores, na maior ou menor eficácia dos pontos de vista que defendem, na solidez dos argurrientos apresentados. Atente, também, para o comportamento do mediador, garantindo o espaço da divergência, a convivência entre pontos de vista conflitantes etc. Além de pesquisarem na internet outros exemplos do debate, você e seus colegas podem gravar debates realizados em sala, para registrá-los e revê-los criticamente. Disponível em: <http://ler.vc/oi96k4>. Acesso em: 29 jan. 2013. 
Para contextualizar a proposta, o livro traz a informação de que "a autora da saga Crepúsculo, Stephenie Meyer, revela em quais clássicos da literatura se inspirou para escrever cada um de seus romances best-sellers, transformados em filmes campeões de bilheteria" (AMARAL et al, 2013b, p. 389).

Por fim, após estabelecer as relações entre as obras de Meyer (1) Crepúsculo, (2) Lua Nova, (3) Eclipse e (4) Amanhecer com os clássicos (1a) Orgulho e preconceito (de Jane Austen), (2a) Romeu e Julieta (de Shakespeare), (3a) O morro dos ventos uivantes (de Emily Brontë) e (4a) Sonho de uma noite de verão, além de $O$ mercador de Veneza (de Shakespeare), a obra apresenta o enunciado norteador do debate:

Há quem pense que adaptações e releituras são um obstáculo à formação de novos leitores: viciados em versões mais digeríveis, eles nunca se interessariam pelas obras originais. Outros acreditam que essa ponte criada pelos best-sellers e blockbusters pode despertar a curiosidade dos jovens para a leitura.

O que você pensa?

(AMARAL et al, 2013b, p. 390)

A proposta permite a realização de um debate de opinião de fundo controverso (DOLZ, SCHNEUWLY, DE PIETRO, 2004) e, no nosso entender, o tema é significativo para levar o aluno a desenvolver sua voz de autoria, contribuindo para sua formação cidadã.

Sentimos falta, no entanto, de uma orientação voltada para a reflexão sobre a situação de interação: características dos interlocutores envolvidos, atenção às expressões e gestos e, especialmente, à entonação expressiva, que pode levar o aluno a compreender inclusive o não-dito.

No volume 3 são apresentadas dez propostas de debate: sete no interior do caderno Literatura (cap. 1, 2, 3, 4, 5, 7 e 10) e três no caderno de Redação e leitura (cap. 1, 4 e 6). Todas dispostas na seção "E mais", como é recorrente nesta coleção.

Nos capítulos 1 ("O Pré-Modernismo") e 2 ("As vanguardas artísticas europeias e o Modernismo no Brasil") do caderno de Literatura do volume 3, o aluno é orientado a realizar um debate interdisciplinar. 
As atividades que antecedem a orientação de debate no capítulo 1 são três leituras de fragmentos de textos literários (Urupés, de Monteiro Lobato; Os sertões, de Euclides da Cunha; e Triste fim de Policarpo Quaresma, de Lima Barreto) e uma atividade de interpretação, com questões a serem respondidas pelos alunos. É neste contexto que a proposta é apresentada:

Debate interdisciplinar - a atualidade do problema dos "dois Brasis"

Discuta com seus colegas em que medida o problema da contradição entre o desenvolvimento e atraso, historicamente existente em nosso país, mantém-se atual. Por meio da orientação de seus professores, procure na internet filmes, documentários, fotos, textos e músicas para enriquecer o seu ponto de vista sobre o tema.

(AMARAL et al, 2013c, p. 21)

O debate surge, então, como consequência de uma reflexão iniciada a partir das leituras sobre o sertanejo e o caboclo e visa à atualização do tema, de forma a contribuir para que o aluno faça relação com sua própria realidade, o que vai ao encontro das OCEM, visto esta defender a escolha de "textos que melhor representam sua [do aluno] realidade". (BRASIL, 2006, p. 28)

O aspecto interdisciplinar está explicitado apenas nas orientações para o professor, ao lado da própria seção: “(...) seria interessante que essa discussão fosse enriquecida com a contribuição de textos de várias disciplinas, como história, geografia, sociologia, filosofia e artes." (AMARAL et al, 2013c, p. 21), ou seja, para o aluno, isso fica subentendido quando este é orientado a pesquisar textos, filmes, músicas, dentre outros.

Nas OCEM (BRASIL, 2006), há a defesa de um trabalho em que não haja uma fragmentação do conhecimento. As relações entre as disciplinas propostas nas atividades analisadas podem ser, portanto, uma resposta ao que sugere 0 documento.

No capítulo 2, essa sugestão de trabalho interdisciplinar fica mais apagada, visto que não há indicação nem no livro do aluno e nem nas orientações para o professor sobre como isso pode ser feito. A proposta apresentada é, como visto anteriormente, de natureza temática, sem indicação de procedimentos para a realização do debate, nem reflexões acerca da linguagem específica desse gênero: “Com o apoio de material apresentado na seção 'Navegar é preciso', enumere e 
discuta pontos positivos e negativos do desenvolvimento das ciências e da tecnologia no século XXI." (AMARAL et al, 2013c, p. 38).

A seção Navegar é preciso, citada na comanda da proposta, precede o quadro "E mais" desse capítulo e orienta o aluno a pesquisar na internet três filmes: Viagem à Lua (direção de George Méliès, França, 1902), Frankenstein (direção de J. Searle Dawley, EUA, 1910) e Nós que aqui estamos por vós esperamos (direção de Marcelo Massagão, Brasil, 1999).

Tanto no capítulo 1 , quanto no 2 , o gênero debate não é tomado como objeto de ensino, visto que traz apenas a indicação de uma orientação temática. Ele exerce a função de prática social, ocasião em que o aluno poderá fazer uso dos conhecimentos construídos a partir de seus estudos para chegar a um consenso com seus colegas sobre as temáticas propostas.

Essa estratégia de associar pesquisas prévias que deem base para a realização de um debate ou, ao contrário, de orientar uma pesquisa que dê suporte à opinião a ser defendida também fica explicitada nos capítulos 3 e 4 .

As leituras realizadas pelos alunos servirão de base para o debate posterior e funcionarão como um discurso internamente persuasivo (BAKHTIN, 193036/2015), marcando a presença da palavra alheia no momento da produção.

No capítulo 3 ("Semana de Arte Moderna"), a proposta de debate está dividida em dois momentos: exposição de opinião a partir da leitura de um fragmento de texto e pesquisa de obras contemporâneas para dar suporte à argumentação.

Debate e pesquisa

1. $\mathrm{Na}$ sua opinião, o artista contemporâneo se parece com o caracterizado pelo poeta Ferreira Gullar neste trecho de entrevista? Por quais razões?

[O texto defende que no passado o artista orgulhava-se em se espelhar em outros artistas, mas, atualmente, isso não é valorizado: "todo mundo quer inventar a arte por si mesmo, todo mundo quer ser pai e mãe de si mesmo." (Ferreira Gullar). O poeta deixa subentendido que isso é impossível, pois ninguém cria do nada.]

2. Pesquise em sites de música, literatura, cinema, quadrinhos, e também nas redes sociais, obras contemporâneas que sustentem a sua opinião sobre o assunto.

(AMARAL et al, 2013c, p. 50). 
No capítulo 4 ("A primeira geração modernista brasileira"), ocorre o movimento oposto: primeiro o aluno pesquisa e, em seguida, participa de um debate. A proposta vem orientada após a leitura de um fragmento de Macunaíma (de Mário de Andrade) e de um texto didático que fala sobre essa obra.

Os alunos são orientados, na seção "E mais", a ler a obra na íntegra e a pesquisar dois desdobramentos dela: (1) um samba-enredo (1975) da escola Portela, e (2) um filme, de Joaquim Pedro de Andrade, que leva o mesmo nome do livro (1969). Em seguida, há uma sequência de ações que os alunos podem realizar, entre elas está o debate.

3. A partir do que você e seu grupo realizaram nas etapas anteriores [faz referência à leitura de Macunaíma e às duas pesquisas], elabore uma das seguintes atividades.

a) Um comentário crítico do samba-enredo, relacionando-o na sua forma e no seu tema com o livro de Mário de Andrade.

b) Um comentário crítico do filme, encontrando semelhanças e diferenças entre ele e o livro de Mário de Andrade.

c) Uma comparação entre o samba-enredo e o filme.

d) Um debate, agora mais aprofundado, sobre a questão já proposta ${ }^{83}$ : em que medida Macunaíma continua sendo (ou não) símbolo do Brasil?

(AMARAL et al, 2013c, p. 69. Grifo nosso.).

A proposta apresentada no capítulo 4 deixa a realização do debate no campo da "possibilidade", ou seja, como o aluno pode decidir realizar "uma das" tarefas (conforme destacamos acima) e como a questão apresentada retoma, de certa forma, uma discussão já realizada, não é possível garantir que ela seja de fato efetivada. Caberá, então, ao docente, orientar esse trabalho de forma a propiciar a realização desta atividade.

No que tange à temática posta em discussão nos capítulos 3 e 4, embora ambas estejam atreladas às obras literárias que são foco de estudo no volume, a indicação de uma reflexão mais ampla, que interliga a literatura com a realidade social do aluno, pode permitir um aprofundamento das percepções deste, levando-o a uma tomada de posição autoral relevante. Sua voz, assim, poderá ser ouvida.

Enquanto o debate aparece como prática social nas atividades presentes nos capítulos 1 a 4, no capítulo 5 este gênero, embora mencionado no título da

\footnotetext{
${ }^{83} \mathrm{Na}$ seção Em tom de conversa, o aluno é orientado a comentar com os colegas se Macunaíma é, de fato, "representativo no Brasil, em especial, do Brasil do século XXI." (AMARAL et al, 2013c, p. $68)$.
} 
seção "E mais", não é explorado efetivamente. A proposta está ligada à leitura de uma peça teatral.

\section{Dramatização e debate}

Para realizar esta atividade, a sala será dividida em grupos. Após ler atentamente o trecho da peça teatral $O$ fingidor, cada grupo vai propor um tipo de dramatização, à qual se seguirá de um debate. Por se tratar de uma peça que explora o imaginário, ela pode ser interpretada de modo criativo: na incorporação de Fernando Pessoa e dos heterônimos; na organização cênica, na escolha de figurinos, músicas, poemas etc.

[LEITURA DA PEÇA TEATRAL "O FINGIDOR”, de Samir Yazbek.]

(AMARAL et al, 2013c, p. 86.Grifo nosso.)

Após esta leitura são propostas algumas questões. Estas, no entanto, exploram mais capacidades leitoras, estão relacionadas, portanto, à compreensão textual. A explicitação de um posicionamento que precisa ser defendido parece ficar em segundo plano nesta atividade, abrindo maior espaço para a oralização das respostas.

\section{Roteiro de debate}

1. Você já sabe que uma peça teatral é escrita para ser lida, mas também, sobretudo, para ser encenada e virar espetáculo. Para o espectador, que não tem o texto em mãos, quais trechos das falas permitem que ele identifique qual dos atores representa cada heterônimo de Pessoa, nesta primeira aparição em cena?

2. Por meio dos diálogos, é possível depreender características da personalidade de Álvaro de Campos? E dos outros dois heterônimos?

3. Após o exercício de dramatização, que Ihe permitiu aprofundar-se em algumas particularidades da obra de Fernando Pessoa, responda: Por que o poeta decide, no final de sua vida, substituir os antigos heterônimos por um personagem? Ou seja, qual é a diferença entre um e outro:

a) do ponto de vista de Fernando Pessoa?

b) do seu ponto de vista?

(AMARAL et al, 2013c, p. 88.)

No que tange à temática sugerida, como ela gira em torno apenas do texto de leitura - na relação entre "heterônimos" e "personagens" - não permite ao aluno um aprofundamento ou uma ampliação que favoreça o desenvolvimento de sua voz 
autoral. A tendência, portanto, é que ele reproduza um discurso advindo da análise linguística realizada.

Diferentemente, nos capítulos 7 e 10, os dois últimos do caderno Literatura em que um trabalho com debate é orientado no volume 3 , observamos duas atividades em que, apesar de haver uma relação com o conteúdo de ensino, a proposição apresentada permite ao aluno relacionar e ampliar o tema a partir de sua relação com sua vida social.

O capítulo 7 ("A segunda geração modernista brasileira: prosa") traz, antes da seção "E mais", diversas leituras e textos didáticos que tratam de obras como "Fogo Morto", de José Lins do Rego, "Vidas Secas" e "São Bernardo", de Graciliano Ramos. Após os textos, são propostas questões de compreensão textual. A orientação do debate tem relação com essas leituras e busca aproximar o conceito de "reificação do indivíduo" com as obras artísticas da contemporaneidade.

\begin{abstract}
Debate
Discuta com seus colegas: Em que medida o tema da reificação do indivíduo, tão presente em nossa vida contemporânea, é representado artisticamente, por meio de filmes, música, histórias em quadrinhos, entre outras manifestações?

Procure encontrar exemplos da presença desse tema em obras que você conhece e trazê-las para o debate.
\end{abstract}

(AMARAL et al, 2013c, p. 120.)

O capítulo 10 ("Tendências contemporâneas da literatura brasileira") focaliza, na proposição do debate, a relação entre vanguarda e (sub)desenvolvimento a partir da leitura de um texto de Ferreira Gullar.

\title{
Debate
}

Em Vanguarda e subdesenvolvimento, publicado em 1969, Ferreira Gullar escreveu:

"A questão que agora se coloca é a seguinte: essas concepções de vanguarda artística correspondem a uma necessidade efetiva das sociedades subdesenvolvidas? As necessidades que, nessas sociedades, determinam a adoção das vanguardas europeias são as mesmas que, na Europa, determinaram seu surgimento? O que é "vanguarda" num país desenvolvido será obrigatoriamente vanguarda num país subdesenvolvido?"

(GULLAR, Ferreira. Vanguarda e subdesenvolvimento: ensaios sobre arte. 3.ed. Rio de Janeiro: José Olympio, 2002. p. 184-185). 
Discuta com seus colegas: na sua opinião, a questão colocada por Gullar, na década de 1960, está ultrapassada ou permanece atual? Por quais motivos?

(AMARAL et al, 2013c, p. 167.)

Ao propor a discussão da atualidade dos aspectos estudados no capítulo, a proposta alcança uma dimensão mais ampla, visto que o aluno terá que conhecer não apenas os conceitos apresentados, mas estar atento às características de sua época, o que possibilitaria a ele trazer seu posicionamento valorativo em relação aos aspectos artístico-literários tratados.

Nos dois capítulos, não observamos uma preocupação com o ensino do gênero em si, mas de seu uso, em uma prática social presente no interior da esfera escolar. Em outras palavras, é uma proposição do uso do gênero debate, em contexto real de interação.

O movimento metodológico apresentado, no entanto, que funciona como leitura/pesquisa, seguida de debate, evidencia uma significativa ausência de orientação quanto aos procedimentos de como o debate deve ser realizado. Nesse aspecto, distancia-se do que é proposto no Edital, o qual estabelece que um dos objetivos do trabalho com oralidade é "orientar a construção do plano textual dos gêneros orais (critérios de seleção e hierarquização de informações, padrões de organização geral, recursos de coesão)". (BRASIL, 2013b, p. 45)

As três últimas propostas de debate do volume 3 estão, como dissemos anteriormente, no caderno Redação e Leitura (cap. 1, 4 e 6), também, como é comum nesta coleção, na seção "E mais".

No capítulo 1 ("O mundo dissertativo"), a orientação para o debate vem introduzida pela leitura de uma proposta de redação do Enem cujo tema gira em torno da cidadania e participação social. Os alunos são convidados a analisar a questão e produzir, em seguida, um texto em prosa do tipo dissertativoargumentativo sobre o tema que ela aborda. O livro orienta, ainda: "depois de selecionar, organizar e relacionar os argumentos, fatos e opiniões apresentados em defesa de seu ponto de vista, elabore uma proposta de ação social". (AMARAL et al, 2013c, p. 315. Grifo nosso.)

É após essa produção escrita que o debate é orientado: 
Debate

Agora você vai participar de um debate inspirado na proposta do Enem.

Reúna-se com seus colegas e discuta com eles o tema Cidadania e participação social. Depois, individualmente e por escrito, selecione e organize os argumentos, fatos e opiniões apresentados que achou mais contundentes e use-os em defesa de seu ponto de vista para apresentar sua proposta de ação social.

(AMARAL et al, 2013c, p. 315. Grifo do autor.)

A temática apresentada ("Cidadania e participação social”) é relevante e possibilita uma discussão que favorece a formação ética e política do aluno, contribuindo para uma tomada de posição deste.

Esse debate de opinião de fundo controverso é proposto, como vimos, após a escrita de uma dissertação sobre o mesmo tema. Se, por um lado, essa escrita prévia pode ser significativa para dar base à discussão proposta no debate, funcionando como discurso internamente persuasivo (BAKHTIN, 1930-36/2015), por outro, preocupa-nos que este momento possa significar apenas a leitura das produções escritas, sem que, de fato, haja interação oral entre os alunos. Assim, no interior do evento, é o docente quem deverá conduzir a atividade de forma a propiciar não apenas a exposição do que já havia sido preparado, mas, efetivamente, a troca de pontos de vista dos alunos de forma oral.

O fechamento deste debate pareceu-nos uma repetição do que já havia sido orientado antes do debate: a escrita de uma proposta de ação social. A própria organização linguística do enunciado é semelhante, como reproduzimos a seguir:

(ANTES DO DEBATE) "Depois de selecionar, organizar e relacionar os argumentos, fatos e opiniões apresentados em defesa de seu ponto de vista, elabore uma proposta de ação social”. (AMARAL et al, 2013c, p. 315. Grifo nosso.)

(DEPOIS DO DEBATE) "Depois, individualmente e por escrito, selecione e organize os argumentos, fatos e opiniões apresentados que achou mais contundentes e useos em defesa de seu ponto de vista para apresentar sua proposta de ação social." (AMARAL et al, 2013c, p. 315. Grifo do autor.)

Não fica claro, portanto, se, no momento do debate, os alunos serão orientados a discutir sobre essas propostas, porque já pensaram nelas anteriormente, se eles farão uma primeira discussão oral e depois registrarão por escrito, ou se eles devem escrever suas ideias inicialmente e reformulá-las após o 
debate com os colegas da turma. Desta forma, será tarefa do professor definir em que momento essa atividade será realizada e como ela será feita.

No capítulo 4 ("A argumentação causal. A importância dos exemplos.") outro debate de opinião de fundo controverso é apresentado ao aluno. Há, inicialmente a indicação de leitura do texto "Carta a um adolescente", de Rubem Alves, seguida por questões de compreensão textual. A orientação do debate é proposta a partir dessa leitura:

\begin{abstract}
Debate
A seguir aparecem algumas afirmações de Rubem Alves retiradas do texto. Escolha uma para discutir com seus colegas, dizendo se concorda ou discorda (parcial ou totalmente) do ponto de vista apresentado. Não se esqueça de dar os motivos, as razões, as causas que justificam sua opinião e de citar exemplos que possam fundamentá-la.

- "O amor faz isso: coloca o outro dentro da gente. O que o outro sente, a gente sente também."

- "Nós, humanos, temos olhos deformados - não percebemos a beleza dos seres que são diferentes da gente."

- "Bondade é o poder usado para a vida. Maldade é o poder usado para a morte."

- "No grupo a gente perde o senso da responsabilidade moral."
\end{abstract}

(AMARAL et al, 2013c, p. 343.)

A proposta permite aos alunos decidirem o tema de maior interesse a ser discutido, visto que eles devem fazer uma escolha em relação aos quatro sugeridos a partir das frases retiradas do texto de leitura e não fazer um debate que inclua tudo. Assim, um debate deliberativo - em que se faz necessária a tomada de posição para que haja uma única escolha do grupo - como apontado por Dolz, Schneuwly e Pietro (2004), precede, neste caso, a realização do debate de opinião.

Os temas em foco nesta atividade são (1) o amor, (2) a visão do homem sobre o homem, (3) a relação entre bondade e maldade e, por fim, (4) responsabilidade moral. Todos permitem ao aluno uma tomada de posição, e, portanto, permitem o desenvolvimento de sua voz autoral.

Visto que não são dadas orientações mais pontuais em relação à produção do gênero debate, nem em relação à sua organização, nem em relação aos elementos linguístico-discursivos que o estruturam, é possível afirmar que o gênero está ligado a seu uso, como prática social. 
Não diferente disso, é a última atividade de debate do volume 3 - e da coleção, portanto. O capítulo 6 (“Estratégias lógico-discursivas”), do eixo de Redação e leitura, também orienta a realização do debate a partir da proposição temática. A diferença está no fato de que não são dados os temas diretamente, mas parágrafos para leitura e é a partir deles que o debate deve se realizar.

São apresentadas ao aluno oito introduções de textos de fontes diversas, com cerca de dois a quatro parágrafos cada, as quais ocupam três páginas do capítulo. O tópico frasal de cada introdução, sua autoria e onde foi publicado figuram abaixo:

Tabela 24: Leituras para debate no capítulo 6 - Col.2-NP

\begin{tabular}{|c|c|c|c|}
\hline & Tópico frasal & $\begin{array}{l}\text { Autoria do } \\
\text { texto }\end{array}$ & $\begin{array}{l}\text { Onde e quando } \\
\text { circulou? }\end{array}$ \\
\hline $\begin{array}{c}\text { Introdução } \\
1\end{array}$ & $\begin{array}{l}\text { "A vida é uma emergência da Terra e a } \\
\text { história da vida possibilitou a vida } \\
\text { humana." (p. } 376)\end{array}$ & Leonardo Boff & $\begin{array}{l}\text { Livro - Nova era: a } \\
\text { civilização planetária. } \\
\text { (1994) }\end{array}$ \\
\hline $\begin{array}{l}\text { Introdução } \\
2\end{array}$ & $\begin{array}{l}\text { "O carnaval de hoje não é mais o dos } \\
\text { meus dez anos, em que meu pai me } \\
\text { punha um lança-perfume na mão e me } \\
\text { deixava na porta do baile infantil, } \\
\text { fantasiado de Zorro." (p. } 376 \text { ) }\end{array}$ & Ruy Castro & $\begin{array}{l}\text { Jornal - Folha de S. } \\
\text { Paulo } \\
\text { (2011) }\end{array}$ \\
\hline $\begin{array}{l}\text { Introdução } \\
\mathbf{3}\end{array}$ & $\begin{array}{l}\text { "Nunca antes tivemos tanta liberdade, } \\
\text { informação e consumo, em termos gerais. } \\
\text { Mas o que temos feito disso?" (p. 376) }\end{array}$ & Daniel Piza & $\begin{array}{l}\text { Jornal - } \\
\text { O Estado de S. Paulo } \\
\text { (2011) }\end{array}$ \\
\hline $\begin{array}{l}\text { Introdução } \\
4\end{array}$ & $\begin{array}{l}\text { "O mundo é um palco e todos os homens } \\
\text { e mulheres são meros atores." (p. 377) }\end{array}$ & $\begin{array}{l}\text { Roberto } \\
\text { Damatta }\end{array}$ & $\begin{array}{l}\text { Jornal - } \\
\text { O Estado de S. Paulo } \\
\text { (2012) }\end{array}$ \\
\hline $\begin{array}{l}\text { Introdução } \\
\quad 5\end{array}$ & $\begin{array}{l}\text { "O termo 'sustentabilidade' está na 'moda' } \\
\text { há algum tempo, mas você sabe o que } \\
\text { ele significa?" (p. } 377 \text { ) }\end{array}$ & Revista do Idec & $\begin{array}{l}\text { Revista- } \\
\text { Revista do Idec } \\
\text { (2011) }\end{array}$ \\
\hline $\begin{array}{l}\text { Introdução } \\
\quad 6\end{array}$ & $\begin{array}{l}\text { "As estatísticas são alarmantes. A revista } \\
\text { New Scientist (28/07) diz que } 1 \% \text { da } \\
\text { população norte-americana controla } 40 \% \\
\text { da riqueza." (p. } 377 \text { ) }\end{array}$ & $\begin{array}{l}\text { Washington } \\
\text { Novaes }\end{array}$ & $\begin{array}{l}\text { Jornal - } \\
\text { O Estado de S. Paulo } \\
\text { (2012) }\end{array}$ \\
\hline $\begin{array}{l}\text { Introdução } \\
7\end{array}$ & $\begin{array}{l}\text { "Todos nós trazemos no corpo as marcas } \\
\text { de uma profunda identidade com o } \\
\text { planeta." (p. 378) }\end{array}$ & André Trigueiro & $\begin{array}{l}\text { Revista - } \\
\text { Mundo Sustentável } \\
\text { (2003) }\end{array}$ \\
\hline $\begin{array}{l}\text { Introdução } \\
\quad 8\end{array}$ & $\begin{array}{l}\text { [Depoimento de um ativista indiano] } \\
\text { "A minha luta contra o trabalho infantil } \\
\text { começou há } 30 \text { anos. Nesse tempo, } \\
\text { aprendi coisas importantes. Uma delas é } \\
\text { que essas crianças têm enorme poder de } \\
\text { mudar a vida delas. Basta que lhes deem } \\
\text { educação, cuidados médicos e } \\
\text { psicológicos." (p. } 378 \text { ) }\end{array}$ & $\begin{array}{l}\text { Satyarthi } \\
\text { Kailash }\end{array}$ & $\begin{array}{l}\text { Jornal - } \\
\text { Folha de S. Paulo } \\
\text { (2012) }\end{array}$ \\
\hline
\end{tabular}


Essas leituras integram o exercício 5 da seção "Atividades", que antecede a seção "E mais". O LDP-EM toma esses textos já lidos como base para a realização do debate, o qual apresenta a seguinte proposição:

Debate regrado

Reúna-se com um grupo de colegas e elabore, por meio das etapas indicadas, um trabalho totalizante e coletivo: uma série de debates regrados da classe sobre os temas das introduções da atividade anterior, desenvolvendo uma argumentação consistente. Em seguida, faça uma avaliação escrita dos pontos positivos e negativos da experiência.

(AMARAL et al, 2013c, p. 379. Grifo nosso.)

Apesar de os alunos terem lido as introduções do exercício 5 (que solicitava a classificação de cada uma em relação ao processo lógico-expositivo predominante), os temas delas não estão expressos no livro do aluno, o que demandará uma atenção maior para que os grupos recuperem a ideia central apresentada em cada um dos textos indicados.

Como no manual do professor, também não há uma indicação quanto a essas temáticas, sintetizamos, a partir de nossa leitura, os temas de discussão que as leituras suscitaram.

Tabela 25: Possíveis temas para debate - col.2-NP

Introdução Temas gerados a partir da leitura de fragmentos textuais propostos no LDP-EM

1 Existe um princípio inteligente entre os seres vivos que os conecta? Há uma base física para este parentesco real?

2 Que mudanças ocorreram no Carnaval ao longo do tempo? Qual sua apreciação em relação a elas?

3 De que forma a nossa vida acelerada pode prejudicar o ser humano? / Você concorda com a afirmação de que "o humanismo tem sido atropelado por nossa vida acelerada"? Justifique.

$4 \quad$ Homens e mulheres são meros atores no palco do mundo? Explique e justifique sua opinião.

5 Como a sustentabilidade pode ser traduzida em práticas e propostas concretas para a melhoria do mundo?

6 Que consequências pode haver quando uma pequena parte da população detém a maior parte da riqueza de um país?

7 De que forma a tese de que "trazemos no corpo as marcas de uma profunda identidade com o planeta" nos ajuda a refletir sobre nossa relação com o meio ambiente?

8 Que esforços os governos deveriam fazer para resolver o problema do trabalho escravo infantil e o tráfico de crianças? 
Quanto à temática posta em discussão, observa-se que a maioria permite uma reflexão acerca de questões polêmicas, o que abre espaço para um debate de opinião de fundo controverso.

Após o enunciado inicial da seção, o LDP-EM apresenta um quadro que traz as características do debate regrado, evidenciando o que é, finalidade, interlocutores envolvidos e o papel de cada um deles. Além disso, tocam na importância da cortesia entre os participantes, os quais devem "ouvir com respeito as ideias alheias" (AMARAL et al, 2013c, p. 380)

Figura 13: $O$ debate e o momento de interação - Col.2-NP

\section{Características de um debate regrado}

O debate regrado é um gênero oral que geralmente se desenvolve em espaços públicos, como auditórios, salas de aula, programas de rádio etc., entre pessoas que defendem opiniões divergentes a respeito de temas polêmicos.

Como ocorre em qualquer tipo de discussão, o objetivo dos interlocutores é o convencimento do outro, a conquista de sua adesão, o que implica cuidadosa escolha dos argumentos e outros recursos persuasivos.

Nesse contexto, todos os participantes têm o direito de expor livremente o que pensam e o dever de, em contrapartida, ouvir com respeito as ideias alheias.

O debate regrado conta com a presença de um moderador para dirigir o andamento das questões, mediando as diferentes posições dos debatedores, facilitando as trocas, arbitrando e conciliando conflitos. O papel do moderador não se restringe aos participantes, mas se estende também ao auditório.

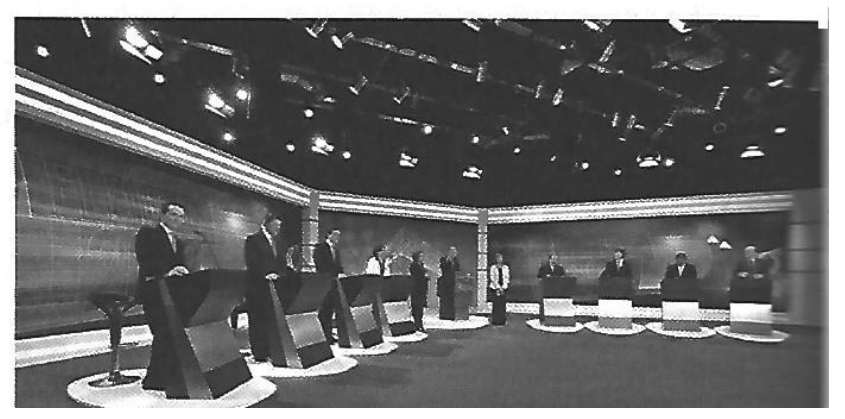

(AMARAL et al, 2013c, p. 380)

Este quadro, presente na col.2-NP, serve de contextualização para introduzir as etapas da atividade a qual está dividida em três partes: preparação, realização e avaliação.

A primeira parte - preparação - estabelece que os grupos devem: (a) escolher o tema que será debatido, dentre as introduções dadas; (b) retomar a leitura escolhida para desenvolver o tema com argumentos e contra-argumentos; (c) 
eleger quem serão os debatedores e o moderador, além de definir o tempo total do debate e o tempo de cada debatedor. (AMARAL et al, 2013c)

A segunda parte - realização -, também dividida em três partes, foca na organização temporal do debate e reforça a necessidade da exposição de argumentos convincentes para a defesa do ponto de vista. $\mathrm{Na}$ introdução, os alunos debatedores são orientados a "realizar uma apresentação de no máximo cinco minutos, expondo o ponto de vista e alguns argumentos básicos de apoio". Em seguida, no desenvolvimento, a turma terá oportunidade de "problematizar as apresentações por meio de refutações ou réplicas", o que deve ser feito, segundo o LDP-EM, em no máximo 15 minutos. Por fim, na conclusão, será dada a oportunidade para o grupo que iniciou o debate fazer as tréplicas, as respostas às refutações. (AMARAL et al, 2013c, p. 380)

A terceira e última parte - avaliação - estabelece que o professor e os grupos devem "avaliar a experiência, destacando seus pontos positivos e negativos" além de propor sugestões de mudanças para que a próxima atividade de debate seja mais "produtiva e interessante". (AMARAL et al, 2013c, p. 380)

A orientação dessa proposta foi mais estruturada que as demais apresentadas no caderno Redação e leitura, comentadas anteriormente, pois esta não fornece simplesmente o tema ao aluno, mas tenta organizar o momento de interação, indicando que há diferentes funções dos interlocutores e que o tempo precisa ser controlado.

O diálogo com as OCEM então se estabelece, pois estas orientam a proposição de um trabalho com gêneros discursivos "à luz das diferentes dimensões pelas quais eles se constituem". (BRASIL, 2006, p. 36)

Em relação à organização do tempo, no entanto, percebemos que houve uma incoerência, visto que, na etapa de preparação, o aluno é orientado a definir o tempo total do debate, e nas instruções dadas em realização deixa-se determinado que a introdução terá cinco minutos e o desenvolvimento quinze. Assim, de alguma forma, o que foi solicitado no planejamento do debate vai de encontro ao que é proposto na etapa seguinte.

Retomamos, por fim, o enunciado da atividade: "reúna-se (...) e elabore (...) uma série de debates regrados" (AMARAL et al, 2013c, p. 379). Na proposta, falta 
uma orientação de como isso deve ser realizado na sala de aula. O docente terá, então, que dar conta de preencher essas lacunas para organizar como isso será feito no interior do evento.

Ao final da atividade, o livro traz um boxe "Lembrete", em que os alunos são orientados a: (a) organizar a sala para o evento; (b) prestar atenção na postura, no tom e na entonação de voz e na linguagem; (c) respeitar as regras estabelecidas e as exigências do moderador.

Como essas informações são apenas expostas, o professor também poderá valer-se delas para ampliar a discussão proposta, apresentando uma reflexão acerca de questões significativas como entonação expressiva, especialmente visando às estratégias de tomada de posição frente ao dito. Enfim, mais uma vez, a voz do professor será fundamental para contribuir para a formação discente.

Do que foi apresentado, podemos concluir que as atividades de debate presentes na col.2-NP possuem um vínculo com os temas da literatura e apresentam em menor proporção uma discussão pautada em temas polêmicos. Além disso, a preocupação com a exploração de aspectos ligados à maneira de organização do gênero (forma composicional, conteúdo temático e estilo) ocorreu de forma pouco intensa, bem como o desenvolvimento da capacidade de escuta atenta. Também não houve preocupação com uma discussão acerca da relação das modalidades oral e escrita, nem de suas especificidades. Esse perfil evidencia um distanciamento em relação ao que propõe o Edital o que justifica a avaliação apresentada no Guia do PNLD 2015.

(...) o tratamento dado à oralidade se faz através da proposta de discussões, debates livres, apresentações orais, debates interdisciplinares, debates regrados (...). Em termos gerais, no entanto, poucas orientações são dadas ao aluno no que diz respeito à construção de tais gêneros.

(BRASIL, 2014, p. 44. Ênfase nossa.)

O enfoque dado ao trabalho com o gênero debate nessa coleção está marcadamente construído na relação de uso da língua em situações de interação especialmente ligado ao estudo da literatura. A coleção pressupõe que os conhecimentos relativos à organização do gênero são previamente conhecidos pelos alunos e, assim, o debate é abordado como uma prática social. 


\subsection{O debate como prática social em Português, contexto, interlocução e sentido}

A coleção Português, contexto, interlocução e sentido (col.3-PCIS), que se organiza em três grandes divisões internas - "Literatura", "Gramática" e "Produção de textos" -, apresenta sugestões para realização de debates apenas na parte de Literatura e na de Produção de texto.

O Manual do Professor dessa coleção declara que adota "uma perspectiva discursiva a partir da qual [discutem] os aspectos relacionados à escrita e à leitura" (ABAURRE, ABAURRE e PONTARA, 2013a. p. 25 do MP). Tem, portanto, uma afiliação teórica com a teoria dialógica do discurso.

Como explica Bakhtin, os gêneros definem-se como "tipos relativamente estáveis", portanto reconhecíveis pelo usuário da língua. Socialmente constituídos, os gêneros pressupõem a interação por meio da linguagem, o que explicita a sua dimensão discursiva.

(ABAURRE, ABAURRE e PONTARA, 2013a. p. 26 do MP)

Tal afiliação pode ser observada pelo título dos capítulos da parte de produção textual: notícia, reportagem, resenha, crônica, carta aberta, artigo de opinião, editorial, dentre outros.

Apesar de o MP defender que "adotar a dimensão discursiva da linguagem (...) não significará tentar estabelecer uma tipologia exaustiva dos inúmeros gêneros orais e escritos que circulam socialmente" (ABAURRE, ABAURRE e PONTARA, 2013a. p. 26 do MP), há uma prevalência na seleção de gêneros ligados à escritura, visto que gêneros orais não são explorados na íntegra dos capítulos nos três volumes da coleção.

A presença do gênero debate na col.3-PCIS aparece diluída em algumas seções ou boxes no interior de capítulos. Isso acontece de forma explícita para o aluno em dois momentos: na seção "Jogo de ideias" (vol. 1, p. 154) e no boxe "Produção oral" (vol.1, p. 378). Há, ainda, quatro vezes na coleção em que a indicação para a realização de um debate aparece para o professor, nas orientações que acompanham as atividades. 
Tabela 26: Presença do gênero "debate" em seções e boxes - Col.3-PCIS

\begin{tabular}{|c|c|c|c|}
\hline $\begin{array}{c}\text { Divisão da } \\
\text { obra }\end{array}$ & Vol.1 & Vol.2 & Vol.3 \\
\hline Literatura & $\begin{array}{l}\text { Debate oral (p.154) } \\
\text { Seção "Jogo de ideias" } \\
\text { (Livro do aluno e do professor) }\end{array}$ & $\begin{array}{l}\text { Debate (p.69) } \\
\text { Seção "Interações" } \\
\text { (Orientação do livro do } \\
\text { professor) }\end{array}$ & ----- \\
\hline Gramática & ---- & ----- & ---- \\
\hline $\begin{array}{c}\text { Produção } \\
\text { de texto }\end{array}$ & $\begin{array}{l}\text { Debate (p. 328) } \\
\text { Boxe "De olho no filme" } \\
\text { (Orientação do livro do } \\
\text { professor) } \\
\text { Debate (p. 378) } \\
\text { Boxe "Produção oral" } \\
\text { (Livro do aluno e do professor) } \\
\text { Debate (p. 378) } \\
\text { Boxe "De olho no filme" } \\
\text { (Orientação do livro do } \\
\text { professor) }\end{array}$ & $\begin{array}{l}\text { Debate (p.396) } \\
\text { Seção "Conexões: } \\
\text { encontro de linguagens" } \\
\text { (Orientação do livro do } \\
\text { professor) }\end{array}$ & ----- \\
\hline
\end{tabular}

(ABAURRE, ABAURRE e PONTARA, 2013d)

As atividades de debate aparecem com maior frequência no volume $1 \mathrm{e}$ estão ausentes no volume 3 da obra.

Considerando, como as OCEM, que "é na interação em diferentes situações sociais (...) que o sujeito aprende e apreende as formas de funcionamento da língua e os modos de manifestação da linguagem" (BRASIL, 2006, p. 24), a quantidade reduzida de atividades com o gênero debate aponta para um silenciamento da voz do aluno, visto que as oportunidades de sociabilização ficam limitadas.

No vol.1, no interior da seção "Jogo de ideias", este gênero está ligado a um tema da literatura, tratando de diferentes visões do processo de colonização. 
Nesta unidade, você viu que os textos produzidos entre os séculos XVI e XVIII revelam diferentes visões sobre o processo de colonização e seus efeitos sobre o nosso país. De um lado, identificamos o olhar do europeu nos relatos dos viajantes, que descrevem a necessidade de "salvar" os nativos que aqui encontraram. De outro, nos versos de Gregório de Matos e dos inconfidentes árcades, observamos a crítica à ganância e à corrupção dos poderosos e o desejo de conquistar a independência do Brasil.

Para compreender melhor essas diferentes visões e como elas podem ser percebidas na produção literária desse período, propomos que você e seus colegas organizem um debate.

(ABAURRE, ABAURRE e PONTARA, 2013a. p. 154. Grifo do autor)

Em seguida, a seção apresenta duas etapas para a realização do debate: preparação e organização.

Na primeira etapa - preparação - o foco está voltado para a divisão da sala em quatro grupos. Dois deles devem compor a plateia, e têm a função de fazer perguntas aos debatedores. Os outros dois grupos devem escolher dois debatedores (um por grupo) e preparar a argumentação. Um grupo deve defender a favor da perspectiva do "colonizador" (vantagens da colonização) e outro do "colonizado" (desvantagens da colonização).

A fim de ajudar na elaboração da argumentação, são dados aos alunos alguns direcionamentos: "selecionar fatos históricos, informações e trechos das manifestações literárias do período que sustentem o ponto de vista que desejam defender" (ABAURRE, ABAURRE e PONTARA, 2013a. p. 154), e refletir sobre questões como:

$\checkmark$ Quais as intenções dos colonizadores europeus em relação à terra descoberta?

$\checkmark$ Que imagem os colonizadores faziam do povo colonizado e de si mesmos? Que imagem os colonizados faziam do europeu? Por quê?

$\checkmark$ Quais foram as vantagens e as desvantagens do processo de colonização para o nosso país? Por quê?

(ABAURRE, ABAURRE e PONTARA, 2013a. p. 154)

A proposta conduz o aluno a fazer uso do discurso alheio, tomando-o como palavra internamente persuasiva (BAKHTIN, 1930-36/2015). Ao entrar em contato com essas leituras, o aluno tem a possibilidade de ampliar seu conhecimento sobre 
o assunto, o que dará base para uma tomada de posição no momento da defesa de seu ponto de vista.

$\mathrm{Na}$ segunda etapa - organização - as orientações dividem-se em três partes: (1) sorteio do mediador, definição de suas funções e do tempo destinado a cada argumentação; (2) esclarecimento sobre o que cada debatedor deve fazer, como apresentar sua defesa e argumentos, respeitar o tempo e fazer uma pergunta ao outro debatedor para refutar sua posição; (3) orientação da participação da plateia, que deve escolher dois representantes por grupo para questionar os debatedores.

No que tange ao enfoque temático, observamos que ele gira em torno de uma questão histórico-literária e os argumentos deverão ser construídos a partir da seleção dos textos estudados e de pesquisas que comprovem o que se pretende defender. A discussão é feita, portanto, na relação entre vantagens ou desvantagens do colonizador no processo de colonização.

A proposta, apesar de suscitar um debate de opinião por apresentar uma questão polêmica, fica limitada a um exercício escolar e distante dos temas de interesse juvenil.

A atividade funciona como estratégia de uso do gênero debate como prática social, neste caso, servindo como base para a reflexão de aspectos literários estudados pelos alunos. Embora haja alguns direcionamentos para a produção, o gênero não é tomado como objeto de ensino.

Seguindo essa mesma finalidade de abordagem - gênero como prática social - a segunda proposta de debate do volume 1 é apresentada. Ela aparece no boxe "Produção oral", dentro de uma seção que visa à produção de um anúncio. A orientação para essa produção está dividida em três partes: (1) pesquisa e análise de dados sobre o bullying e o ciberbullying; (2) elaboração; (3) reescrita do texto. 0 boxe "Produção oral" integra a parte 1. 
Figura 14: Boxe "produção oral" - Col.3-PCIS

\section{PRODUÇÃO ORAL}

Que tal participar de um debate, com seus colegas, sobre a questão do bullying? Comecem o debate considerando as seguintes questões:

- Você conhece alguém que passou por uma situação de bullying?

- Você tomou algum partido durante o episódio? Qual? Por quê?

- Quando você vê um colega sendo humilhado por outro[s], qual costuma ser a sua reação?

- De que forma essa pessoa poderia buscar ajuda?

- 0 que você faria se estivesse no lugar dela?

Lembre-se de que, em um debate, é importante ouvir de modo atento as opiniões dos colegas, para depois apresentar a sua. Procure fundamentar sua opinião em fatos concretos e argumentos que possam convencer seus colegas.

(ABAURRE, ABAURRE e PONTARA, 2013a. p. 378)

O encaminhamento para essa produção baseia-se em questões, que serão o mote inicial para a discussão da turma. Propõe-se, portanto, a partir de um tema polêmico, um debate de opinião de fundo controverso pertinente ao universo juvenil. Além da orientação temática, a obra busca relembrar o aluno da importância de saber ouvir o outro e de contra argumentar de forma consistente. Não há um ensino pontual em relação a isso, visto que essas informações são passadas em um parágrafo ao final do boxe. A obra pressupõe, assim, que os alunos já saibam como isso deve ser feito.

A referência à escuta atenta mencionada no LDP-EM retoma o discurso do Edital, que defende que o aluno do ensino médio deve "desenvolver a capacidade de escuta atenta e compreensiva" (BRASIL, 2013b, p. 45). Como documento oficial que regula o processo de avaliação das obras didáticas, sabemos que ele exerce, por um lado uma voz autoritária, mas, por outro, também dialoga com as indicações apresentadas nas OCEM, as quais defendem "atividades de escuta de textos (palestras, debates, seminários, etc.)”. (BRASIL, 2006, p. 37).

Considerando que apenas essas duas atividades do livro do aluno tratam do gênero debate, voltamos nosso olhar para observar se havia, nas orientações para o 
professor, alguma indicação para realização de debate. Isso ocorreu em dois momentos do volume 1 e dois no volume 2.

No volume 1, há duas indicações para a produção de debate, colocadas após a seção "De olho no filme". Depois de assistir a cada um deles, deve-se discutir sobre os aspectos por eles tratados.

Uma delas aparece ao lado do boxe de produção oral, em que os alunos já fariam o debate sobre bullying. O filme indicado nesta ocasião foi "As melhores coisas do mundo". A orientação dada ao professor é:

Sugere-se que o filme seja assistido em sala e que, após sua exibição, as questões sejam utilizadas como motivadoras de um debate entre os alunos sobre a prática do bullying. A intenção desta proposta é, além de promover o exercício oral da exposição e da argumentação, criar um contexto para que os alunos reflitam sobre a existência, na escola em que estudam, de situações semelhantes às retratadas no filme e, assim, tomem consciência do problema e sintam-se mais motivados para participar de uma campanha que combata o bullying entre seus colegas e conhecidos. No final da Unidade 3, em "Jogo de ideias", há orientações a respeito de como organizar um debate.

Há cenas de sexo e uma cena em que um aluno tenta suicídio por meio de ingestão de comprimidos.

Há, no Guia de recursos, a indicação do filme Meninas malvadas, de Marla S. Waters, que trata do bullying, agora com meninas, e que também pode ser visto e debatido pelos alunos.

(ABAURRE, ABAURRE e PONTARA, 2013a. p. 378. Grifo nosso.)

Há, portanto, a indicação de três debates em uma mesma página do livro: dois realizados a partir de dois filmes que tratam do bullying ("As melhores coisas do mundo" e "Meninas malvadas") e um sobre o mesmo tema, mas que aparece no livro do aluno. Todas essas interações têm como finalidade a alimentação temática para a produção do anúncio publicitário ao final da seção.

O tratamento do gênero como prática social também é evidenciado pela intenção em exercitar a argumentação oral e refletir sobre a realidade que cerca os jovens, conforme negritamos na citação acima. Para orientar esse trabalho, a obra indica ao professor a retomada da seção "Jogo de ideias" (unidade 3), que foi analisada por nós anteriormente, evidenciando, assim, que os procedimentos para a execução do debate deva ser a separação da sala em debatedores, moderador e 
plateia, a divisão do tempo para cada um e a exposição dos argumentos e perguntas, com direito a réplica e tréplica.

A outra orientação do professor que ocorre ao lado da seção "De olho no filme", encontra-se no cap. 25, que trata do relato, carta pessoal, e-mail e diário. 0 filme em questão é "Central do Brasil". Nesta, também se faz a indicação de que o professor deve observar as etapas de como realizar um trabalho na seção "Jogo de ideias" da Unidade 3, mas se acrescenta três questões para direcionar o debate:

(a) Qual a função da escrita (e da leitura) na vida das pessoas retratadas no filme?;

(b) Qual é o grau de exclusão a que estão submetidos os analfabetos em uma sociedade letrada?;

(c) De que maneira o advento da internet pode agravar esse problema, criando milhões de excluídos digitais?

(ABAURRE, ABAURRE e PONTARA, 2013a. p. 328)

O tema proposto é polêmico e pertinente ao universo juvenil, mas traz, na questão "c" um ponto de vista direcionado, evidenciando um juízo de valor prévio que a obra espera que os alunos considerem como verdade: o advento da internet pode agravar o problema da exclusão da sociedade letrada. Isso é evidenciado no texto de orientação do professor: "O objetivo desse debate é levar os alunos a refletir sobre uma situação que é provavelmente ignorada por eles: os muitos obstáculos que uma sociedade letrada impõe aos analfabetos (...)". (ABAURRE, ABAURRE e PONTARA, 2013a. p. 328). Ao propor de antemão um posicionamento, entendemos que a voz do aluno é silenciada, visto que ele não terá muito espaço para colocar-se frente a essa questão e terá que concordar com a tese apresentada.

No volume 2, não há proposta de debate direcionada especificamente para o aluno, apenas duas sugestões para o professor indicar um debate.

Uma delas aparece na seção "Interações", no caderno de Literatura; a outra, na seção "Conexões: encontro de linguagens", no caderno de Produção de texto.

A seção "Interações", do capítulo 4, que aborda a poesia social da terceira geração, traz um poema de Jorge de Lima, cujo título é "Olá! Negro" e um cartum de Laerte que provoca uma reflexão sobre um número cada vez maior de morte de negros por arma de fogo. A orientação do professor traz então a sugestão do debate: 
Nessa atividade, o aluno é levado a refletir sobre o papel da arte como um instrumento de denúncia de situações de desigualdade e opressão, dentro da tradição da poesia abolicionista, tratada no capítulo. Para tanto, o cartum de Laerte pode levar a um fértil debate a respeito do racismo ainda presente na sociedade brasileira, mesmo que a tarefa abolicionista tenha sido levada a cabo. O cartum aponta que, a despeito do discurso de igualdade racial, ainda podemos perceber imensa desigualdade em fatos concretos, como o número alarmante de jovens negros mortos de forma violenta. Em seguida, ao discutir a relação do poema de Jorge de Lima com o cartum, é interessante que se estabeleçam os vínculos históricos de causalidade entre as duas situações apontadas: a escravidão abordada por Jorge de Lima fundamenta a atual situação dos negros no país. Para acrescentar outros elementos à discussão, seria interessante trazer algumas letras de rap, como as dos Racionais MCs ou Emicida, que abordem, em outra linguagem, a questão racial (...).

(ABAURRE, ABAURRE e PONTARA, 2013b. p. 69. Grifo nosso.)

A proposta evidencia um debate de tema polêmico e socialmente relevante que permitirá ao aluno colocar sua voz, posicionando-se frente ao que é apresentado no poema e no cartum. Como a realização dessa interação fica a critério do professor, por ser uma orientação dada apenas a ele, corre-se o risco de não ser concretizada, se o docente entender que não há tempo didático para isso ou se não considerar relevante.

Também fica a critério do professor, a segunda orientação de debate do volume 2. A seção "Conexões: encontro de linguagens", que encerra o caderno de Produção de Texto com indicações de filmes, livros, sites e músicas sobre temas trabalhados nos capítulos $24,25,26$ e 27 , propõe uma realização de debate sobre um dos filmes referente ao capítulo 24 .

Indicamos o filme Koyaanisqatsi por entender que a sua estrutura, constituída pela sucessão frenética de imagens e alternância de ritmos, desencadeia no observador um processo reflexivo que se assemelha ao trajeto percorrido no momento de criação de uma crônica. Nesse sentido, seria interessante não só assistir ao filme com os alunos, mas também realizar um debate em que eles se manifestem sobre as possíveis intenções do diretor do filme ao adotar essa estrutura, como levar o espectador, durante o tempo da apresentação do filme, a "viver" a experiência de uma vida fora de equilíbrio e, assim, refletir sobre os aspectos da vida moderna que aparecem retratados em Koyaanisqatsi. (...)

(ABAURRE, ABAURRE e PONTARA, 2013b. p. 396. Grifo nosso.) 
Nesta proposta, o debate está relacionado a um filme e parece focalizar mais a análise das estratégias utilizadas pelo diretor para demonstrar ao espectador como "viver' uma vida fora de equilíbrio" (ABAURRE, ABAURRE e PONTARA, 2013b, p. 396). Não foca, portanto, em um tema polêmico.

Observamos, assim, na col.3-PCIS que o gênero debate é tratado como uma prática social e que as propostas apresentadas nem sempre visam a uma discussão de temas polêmicos. Como não há tantas indicações de debate no livro do aluno, a obra busca ampliar essa oferta a partir de orientações para o professor, o que pode ser um recurso pertinente, mas que não garante que efetivamente a proposta se realize, por ser tratada no campo da sugestão apenas. Temos assim, menor possibilidade de o aluno ter sua voz ouvida.

\subsection{O debate como objeto de análise e reflexão em Língua Portuguesa: linguagem e interação}

A organização interna da coleção Língua Portuguesa: linguagem e interação (col.4-LPLI) prevê um trabalho com a linguagem oral em todos os capítulos, ocasião em que se propõe ora uma reflexão sobre as especificidades da oralidade hesitação, reformulação, entoação expressiva etc - ora produção de gêneros orais, como a exposição oral, a entrevista, a mesa redonda e o debate. É também recorrente no volume tanto o uso de textos orais transcritos para análise, quanto $o$ estímulo à reflexão sobre diferenças e semelhanças entre as modalidades oral e escrita.

Essa diversidade de propostas responde aos critérios do Edital para a realização dos trabalhos com a oralidade, validando sua voz.

Assim como no ensino fundamental, as coleções didáticas de LP dirigidas para o ensino médio devem reservar à oralidade uma proposta de ensino-aprendizagem própria. Considerando as demandas dessa etapa de ensino e o perfil de seu alunado, as atividades devem:

- favorecer a reflexão sobre as diferenças e semelhanças que se estabelecem entre as modalidades oral e escrita, combatendo os preconceitos associados às variedades orais;

- explorar gêneros orais adequados a situações comunicativas diversificadas, particularmente os mais relevantes seja para a expressão pública de opinião, seja para o desenvolvimento da autonomia relativa nos estudos (entrevista, jornal falado, debate 
regrado, apresentação de trabalho, seminário, exposição oral etc.);

- desenvolver a capacidade de escuta atenta e compreensiva do aluno;

- orientar a construção do plano textual dos gêneros orais (critérios de seleção e hierarquização de informações, padrões de organização geral, recursos de coesão).

(BRASIL, 2013b, p. 45)

O gênero debate na col.4-LPLI é trabalhado, especialmente, na seção Linguagem oral, a qual, segundo o MP, "está centrada no estudo dos atos de fala e das situações de comunicação." (FARACO, MOURA e MARUXO JR., 2013a, p. 388).

O embasamento teórico da seção está ligado à Análise da Conversação e à teoria dialógica do discurso, em um movimento que procura tanto estimular a reflexão sobre os exemplos transcritos de situação oral, quanto relacionar esses usos às situações práticas da vida.

O Edital (BRASIL, 2013b) não deixa pré-estabelecido que teoria deve ser utilizada na organização das coleções, mas estabelece que deve haver uma clareza quanto à fundamentação teórica na relação entre o que é apresentado ao longo dos volumes e o que é declarado no MP.

Propostas de atividade com o gênero debate estão presentes, ainda, em duas outras seções - Prática de linguagem e Para ir mais longe.

Apesar de não haver um capítulo na íntegra em que este gênero é tomado como objeto de ensino, é possível observar, a seguir, que há nove momentos em que esse estudo é proposto. 
Tabela 27: Presença do gênero "debate" em seções da Col.4-LPLI

\begin{tabular}{|c|c|c|c|c|}
\hline Unid. & Cap. & Vol.1 & Vol.2 & Vol.3 \\
\hline \multirow[t]{3}{*}{1} & 1 & ----- & $\begin{array}{l}\text { Debate televisivo (p.37) } \\
\text { Seção "Linguagem } \\
\text { oral" } \\
\text { Debate televisivo (p.49) } \\
\text { Seção "Para ir mais } \\
\text { longe" }\end{array}$ & ----- \\
\hline & 2 & ---- & ---- & $\begin{array}{l}\text { Debate (p. } 65) \\
\text { Seção "Prática de } \\
\text { linguagem" }\end{array}$ \\
\hline & 3 & ----- & ----- & ----- \\
\hline \multirow[t]{3}{*}{2} & 4 & ---- & ---- & ---- \\
\hline & 5 & ----- & ----- & ----- \\
\hline & 6 & ----- & ----- & ----- \\
\hline \multirow[t]{3}{*}{3} & 7 & ----- & ----- & ----- \\
\hline & 8 & ----- & ----- & ----- \\
\hline & 9 & ----- & ----- & ----- \\
\hline \multirow[t]{3}{*}{4} & 10 & $\begin{array}{l}\text { Debate (p.279-280) } \\
\text { Seção "Linguagem oral" }\end{array}$ & ----- & $\begin{array}{l}\text { Debate regrado (p.281) } \\
\text { Seção "Linguagem oral" }\end{array}$ \\
\hline & 11 & $\begin{array}{l}\text { Debate (p.302) } \\
\text { Seção "Linguagem oral" }\end{array}$ & ----- & $\begin{array}{l}\text { Debate regrado (p.314) } \\
\text { Seção "Linguagem oral" }\end{array}$ \\
\hline & 12 & $\begin{array}{l}\text { Debate (p.326-329) } \\
\text { Seção "Linguagem oral" }\end{array}$ & ----- & $\begin{array}{l}\text { Debate (p.351) } \\
\text { Seção "Para ir mais longe" }\end{array}$ \\
\hline
\end{tabular}

(FARACO, MOURA e MARUXO JR., 2013d)

Como os eixos de ensino estão distribuídos internamente ao longo de cada capítulo na col.4-LPLI ${ }^{84}$, não é possível determinar previamente se as propostas de debate estão ligadas ao eixo de literatura, gramática ou produção de texto. No entanto, a tabela acima evidencia que este estudo é mais comum ao final do ano letivo, visto que em dois volumes o gênero debate é explorado na última unidade.

No volume 1 , os três capítulos finais têm como foco norteador os gêneros artigo de opinião, editorial e carta do leitor, respectivamente. Neste contexto, a seção Linguagem oral dos três traz a indicação do estudo do gênero debate, numa proposta que visa uma continuidade e progressão.

A primeira leva o aluno a relacionar o artigo de opinião - trabalhado na seção Gramática textual - ao debate, no que se refere à questão polêmica, evidenciando que "além do artigo de opinião, há outras maneiras de expressar

\footnotetext{
${ }^{84}$ A tabela 18, apresentada no capítulo anterior, evidenciou a forma de organização dessa coleção.
} 
argumentos [e que] na linguagem oral, muitas vezes argumentamos por meio de debates". (FARACO, MOURA e MARUXO JR., 2013a, p. 279. Grifo do autor).

A temática proposta para essa discussão retoma temas sugeridos em seção anterior (Gramática textual), ocasião em que os alunos registraram por escrito suas opiniões e argumentos sobre três afirmações: (a) a beleza física é um valor do mundo moderno; (b) a evolução da sociedade humana levará os homens à destruição; (c) os meninos amadurecem mais depressa que as meninas. (FARACO, MOURA e MARUXO JR., 2013a, p. 271). A orientação para o aluno é que a turma deve escolher apenas um desses três tópicos para discutir.

A oportunização de debate sobre esses temas polêmicos, previamente refletidos e registrados por escrito, pode "promover um ambiente profícuo (...) à investigação sobre as relações entre os gêneros da oralidade e da escrita, sobre a variação linguística, sobre níveis de formalidade no uso da língua, por exemplo." (BRASIL, 2006, p. 37). Estabelece-se, assim, mais uma resposta às OCEM.

As orientações dadas após essa primeira indicação temática estão tanto ligadas à organização da turma para a realização do debate - divisão da turma em dois grupos (um com posição favorável ao tema e outro com posição contrária), escolha de quem serão os debatedores de cada grupo, definição de que o restante do grupo participará como ouvinte e escolha do mediador - quanto à função de cada participante no momento em que o debate estiver ocorrendo. Assim, segundo a proposta, o mediador dá a palavra aos debatedores, inicia e termina o debate e controla o tempo; os debatedores expõem seu ponto de vista, argumentando e contra argumentando; e os ouvintes, apesar de não participarem diretamente, podem anotar em uma folha de papel algum aspecto importante sobre o tema e entregar para o debatedor de seu grupo.

$\mathrm{Na}$ atividade, os alunos são orientados a gravar o debate para que ele possa ser analisado posteriormente. Os critérios para isso são apresentados em forma de perguntas e divididos em relação tanto ao papel do participante:

I. O papel do mediador:

* Ele soube controlar o tempo de fala?

* Conseguiu dar início ao debate, apresentando claramente a questão polêmica ou o tema que seria debatido? 
* Houve momentos em que o mediador precisou interromper a fala de um dos debatedores? Se isso aconteceu, como ele fez?

* Como foi feito o encerramento do debate?

II. O papel dos ouvintes:

* Os ouvintes prestaram atenção à fala dos debatedores?

* Algum ouvinte interveio diretamente no debate, ou seja, falou diretamente, dirigindo-se aos debatedores? Se isso aconteceu, por que esse ouvinte agiu assim?

* Na situação descrita no item anterior, como o mediador reagiu? O que ele fez?

* E os demais ouvintes, o que fizeram?

* Em algum momento o mediador convocou os ouvintes a também participar do debate? Se isso aconteceu, por que ele o fez?

(FARACO, MOURA e MARUXO JR., 2013a, p. 279-280)

quanto ao desenvolvimento do tema defendido pelo debatedor:

III. O conteúdo do debate:

* As posições defendidas e opiniões dos debatedores ficaram claras para quem ouvia? Se isso não aconteceu, o que, na opinião de vocês, prejudicou o debate?

* O mediador fez perguntas aos debatedores? Essas perguntas pareciam, para quem ouvia o debate, pertinentes ao tema ou fugiam dele?

* Os debatedores procuraram ater-se ao tema ou fugiram da questão polêmica em discussão?

* Houve debatedor que mudou de opinião durante o debate? Se isso aconteceu, por que ele o fez?

(FARACO, MOURA e MARUXO JR., 2013a, p. 280)

Esse roteiro de análise é bastante significativo na obra, uma vez que ele é mencionado nos dois outros momentos de orientação de debate no volume 1, ou seja, sempre que o aluno fizer uma análise, estas questões são tomadas como referenciais para sua realização.

A proposta apresentada toma o gênero debate como objeto de estudo, uma vez que sistematiza as etapas de sua realização e propõe a discussão de um tema polêmico. Sentimos falta de uma orientação, no entanto, para aspectos significativos da interação, como observação de gestos, expressões faciais, movimentação corporal, tom de voz, entre outros, que poderiam ajudar a evidenciar a tomada de posição do aluno frente ao dito. 
A segunda orientação de trabalho com o gênero debate deste volume não apresenta tanto detalhamento em relação aos participantes da interação (uma vez que isso já havia sido explicado em capítulo antecedente), mas propõe uma condução que é bastante semelhante ao que mostramos anteriormente: escolhemse os papéis dos envolvidos (debatedor / ouvinte / moderador) e propõe-se a discussão de uma questão polêmica.

A diferença nesta proposta é que o aluno é quem deve escolher o tema a ser discutido, o debate será feito em pequenos grupos e, dentro destes, deverá haver troca de papeis, ora um aluno será mediador, ora essa mesmo aluno assumirá o papel de debatedor e, por fim, também será ouvinte. Ao final da atividade, o debate deve ser analisado, tomando-se as questões já citadas, que serão norteadoras da análise.

Essa proposta corrobora o discurso das OCEM, que defendem:

(...) o aprendizado da língua implica a apreensão de práticas de linguagem, modos de usos da língua construídos e somente compreendidos nas interações, o que explica a estreita relação entre os participantes de uma dada interação, os objetivos comunicativos que co-constroem e as escolhas linguísticas a que procedem.

(BRASIL, 2006, p. 30)

Por fim, na terceira e última vez em que o debate é mencionado no volume 1 , observamos uma proposta ligada à análise de um debate regrado que circulou socialmente. A seção Linguagem oral traz a transcrição de um debate de rádio que explora a temática do uso das bicicletas no trânsito das grandes cidades. Os alunos são orientados a: (1) analisar a transcrição tendo como critério as questões dadas no capítulo 10, sobre artigo de opinião (transcritas neste trabalho anteriormente); (2) comparar a análise feita nessa atividade com a que foi realizada no capítulo 10, em que os alunos gravaram seu próprio debate.

Além disso, a atividade estimula o aluno a observar se houve diferenças entre a forma de condução da atividade entre os três debates estudados na unidade: 
5. Considerando que os debatedores e o mediador desse debate transcrito são experientes, que diferenças vocês conseguem perceber entre a forma como o debate da rádio foi conduzido e os que vocês conduziram anteriormente, nas atividades orais dos capítulos 10 e 11 ? (se necessário, retomem os registros feitos).

(FARACO, MOURA e MARUXO JR., 2013a, p. 329)

A produção do debate ocorre como um terceiro passo dessa orientação didática, seguindo o caminho de análise, comparação e produção. Apresenta-se, pois, como um resultado de um processo prévio de discussão.

Quanto à proposta temática, ela tem como base um artigo de opinião lido no início do capítulo, o qual trata da bela velhice e defende que alguns aspectos da juventude devem ser preservados ao se chegar à terceira idade. Traz, portanto, uma discussão socialmente relevante que contribui para a formação ética do aluno.

O diálogo estabelecido com as OCEM fica evidente mais uma vez por permitir que os alunos possam "assumir uma postura reflexiva que lhes permita tomar consciência de sua condição e da condição de sua comunidade (...) para poder atuar nelas de forma ativa, como protagonistas na ação coletiva". (BRASIL, 2006, p. 29)

No volume 2, diferentemente do que foi observado no primeiro da coleção, o gênero debate não é tomado como objeto de ensino. Ele é mencionado apenas duas vezes, ambas no capítulo 1, cujo título é "Romance (I)".

A primeira vez ocorre na seção Linguagem oral, em que o estudo do gênero "diálogo" é introduzido. O objetivo da atividade, declarado no livro do aluno, é entender "como se configuram alguns elementos fundamentais da oralidade que a distinguem da escrita". (FARACO, MOURA e MARUXO JR., 2013b, p. 36).

Ao oportunizar esse estudo, a voz do Edital é retomada, pois, "a reflexão sobre as diferenças e semelhanças que se estabelecem entre a modalidade oral e escrita" é um dos objetivos declarados para favorecer o combate contra "os preconceitos associados às variedades orais". (BRASIL, 2013b, p. 45)

A proposta está dividida em duas ações: (1) listar algumas situações de comunicação em que o diálogo pode ser observado; (2) pesquisar uma das situações elencadas anteriormente, para, em seguida, identificar as partes do 
diálogo e analisá-las. O debate regrado é mencionado como sugestão de gênero a ser pesquisado.

2) (...) Pesquisem uma das situações comunicativas nas quais se constatou a presença de diálogos. Sigam o roteiro abaixo.

a) Selecionem um gênero de texto (oral ou escrito) em que se constate a presença do diálogo.

b) Se for gênero escrito (como extrato de romance ou de peça de teatro), identifiquem e destaquem as partes que correspondem ao diálogo, para distingui-las do restante do texto.

c) Se for gênero oral (como a conversa cotidiana, o debate regrado), gravem, de alguma forma, o extrato com o diálogo. Essa gravação pode ser feita por meio de um gravador de fita cassete, por exemplo, ou outro aparelho que permita a reprodução do extrato escolhido.

(FARACO, MOURA e MARUXO JR., 2013b, p. 36-37. Grifo nosso.)

Os critérios para análise focam na identificação se o diálogo é oral ou escrito, qual o gênero textual em que aparece o diálogo, se a comunicação selecionada é de natureza pública ou privada, se a linguagem é formal ou informal e, por fim, quantos são os participantes do diálogo. Para sistematizar, o LDP-EM orienta o aluno a fazer um quadro síntese, evidenciando as características de um diálogo, conforme foi levantado pelo grupo.

A segunda vez em que o gênero debate é citado no capítulo 1, seção Para ir mais longe, a proposta é bastante semelhante: orienta-se a pesquisa de situações de produção de diálogos variadas e sugere-se o "debate televisivo" como uma delas. O enfoque, neste caso, é a discussão sobre a formalidade ou informalidade da linguagem, estabelecendo-se um elo entre usos da língua no interior de uma dada situação comunicativa.

a) Pesquisem e registrem (...) diálogos construídos em diversas situações de comunicação. Selecionem os mais interessantes para analisar a linguagem utilizada.

b) Analisem nesses diálogos o nível de linguagem (formal, informal). Por exemplo, numa conversa entre amigos, sobre futebol, provavelmente predominará o nível informal; num diálogo público (como um debate televisivo), provavelmente o nível seja formal.

c) Relacionem a situação de produção desses diálogos com o grau de formalidade da linguagem empregada neles: a linguagem está de acordo com essa situação comunicativa? Por quê? Registrem suas conclusões.

(FARACO, MOURA e MARUXO JR., 2013b, p. 49. Grifo nosso.) 
Nas duas propostas, o enfoque não está ligado a uma reflexão sobre o gênero debate em si, visto que os alunos podem selecionar inclusive outros gêneros que desejar, desde que contenham um diálogo em sua forma composicional. Além disso, apesar de ser proposto o uso de um gênero que circula efetivamente, o enfoque da atividade não é na prática do debate, mas apenas na análise de sua linguagem. Assim, entendemos que ambas não possibilitam o desenvolvimento da voz autoral do aluno, mas são significativas para uma reflexão acerca da linguagem oral.

No volume 3, a primeira menção ao gênero debate apresenta uma situação semelhante, em que este gênero é apenas citado na seção Prática de linguagem, no interior de uma atividade que propõe a análise de sufixos aumentativos e diminutivos e seus efeitos de sentido em textos orais e escritos.

Reúna-se com alguns colegas e selecionem uma amostra de textos de imprensa em que haja emprego de sufixos. Vocês vão observar neles 0 efeito de sentido provocado pelo uso dos sufixos. Sigam as etapas propostas a seguir.

a) Cada grupo deve escolher uma das áreas. Um exemplo de divisão possível é este:

I. Textos orais (rádio e TV): textos publicitários de rádio e televisão, entrevistas, debates, telejornais.

II. Textos escritos (jornais e revistas impressos): anúncios publicitários, notícias, reportagens, artigos de opinião e ensaios, tiras humorísticas e outros tipos de desenho de imprensa.

(...)

d) Coletivamente formulem conclusões sobre a expressividade dos sufixos aumentativos e diminutivos.

(FARACO, MOURA e MARUXO JR., 2013c, p. 65. Grifo nosso.)

Há, portanto, uma proposta que estimula a reflexão sobre a linguagem em diferentes gêneros orais e escritos, dentre eles o debate. Ele não é tomado como objeto de ensino, mas serve de instrumento para uma análise dos efeitos de sentido que uma determinada estrutura linguística - no caso, aumentativos e diminutivos pode gerar dentro de uma dada situação de comunicação.

O volume 3 apresentada ainda mais três propostas com o debate, nos últimos capítulos $(10,11$ e 12) do livro, no interior da unidade 4. As duas primeiras ocorrem na seção Linguagem oral, que tem como foco o ensino do gênero "Mesa redonda". 
No capítulo 10 - "Correspondência formal argumentativa" - ao descrever o gênero "mesa redonda", a obra faz menção ao fato de que este reúne três outros gêneros: leitura em voz alta ( $\mathrm{sic}$ ), exposição oral e debate regrado. Por este motivo, orienta o aluno a utilizar cada um deles novamente e a gravar essa produção para que se possa analisá-las posteriormente.

Para a leitura em voz alta, orienta-se o aluno a retomar a entrevista realizada no capítulo 9 e a escrever um ensaio sobre o cotidiano e as formas de atuação profissional do entrevistado. Este texto servirá de base não apenas para o momento de leitura, mas para as duas etapas seguintes: exposição oral das ideias centrais do texto e debate sobre o que foi exposto.

A função que o gênero debate exerce nesta proposta está ligada a uma prática social, visto que serve de instrumento para uma sistematização de conhecimento acerca do que os alunos escreveram. Não é possível determinar com exatidão o tema que foi tratado, mas, como o direcionamento para a escrita do ensaio solicitava uma reflexão sobre o cotidiano e as formas de atuação profissional de uma pessoa, entendemos que o debate tenha se encaminhado na mesma direção e, neste sentido, pode não ser tão polêmico.

De forma geral, observa-se que a orientação didática encaminha a discussão de maneira que "o aluno tome a língua escrita e oral (...) como objeto de ensino / estudo / aprendizagem (...)", conforme preconizam as OCEM (BRASIL, 2006, p. 33).

No capítulo 11 - "Dissertação em prosa" - a orientação dada na seção Linguagem oral é a de que os alunos façam a análise das gravações feitas no capítulo anterior, tanto da leitura em voz alta, quanto da exposição oral e do debate regrado. Para cada um, são apresentadas questões norteadoras para a reflexão.

No caso do debate regrado, as indagações giraram em torno do papel do mediador, do ouvinte e do conteúdo do debate, retomando, de alguma forma, o quadro apresentado no volume 1 e que já foi comentado em nosso estudo.

Sobre o papel do mediador, as questões focalizavam o controle do tempo de fala, a apresentação da questão polêmica ou do tema a ser debatido, a postura ao longo do debate (como interrupções necessárias) e o fechamento da atividade. 
Sobre o papel do ouvinte, o LDP-EM estimulou o aluno a pensar sobre a escuta atenta, se houve interrupções (e, neste caso, como reagiram o mediador e os outros ouvintes) e se o mediador convocou a fala de algum ouvinte (e, se o fez, por qual motivo).

Presentes tanto no Edital (BRASIL, 2013b) quanto nas OCEM (BRASIL, 2006), a orientação do desenvolvimento da capacidade de escuta, relacionada ao gênero debate, nem sempre é focalizada. Dessa forma, a proposta trazida nessa atividade tende a contribuir para essa reflexão.

Em relação ao conteúdo, as questões estavam voltadas para observar se as posições defendidas pelos debatedores estavam claras, se estes fugiram ao tema, se algum deles mudou de opinião, se eles foram convincentes e se as perguntas do mediador foram pertinentes ao longo do debate.

Considerando que esta foi uma atividade de análise e que os tópicos dados como critérios norteadores estão ligados à situação comunicativa, o gênero debate foi tomado como objeto de ensino, embora esta ação não esteja diretamente ligada ao ensino deste gênero, mas a um procedimento interno do gênero "mesa redonda", como explicitado no LDP-EM.

Por fim, a última orientação de debate da coleção é apresentada no capítulo 12 - "Discurso político" - na seção Para ir mais longe e propõe a realização de um conjunto de debates - ou mesas-redondas - sobre as principais questões polêmicas no campo político.

A política é um campo em que muitas questões polêmicas são debatidas. Essas questões são, em geral, de grande importância social porque se relacionam à nossa vida em sociedade. Vamos analisar textos dessa natureza.

Selecione alguns textos publicados em veículos de comunicação de sua região para a análise proposta aqui.

a) Faça um levantamento das principais questões polêmicas discutidas no campo político.

b) Com a ajuda do professor, você e seus colegas devem organizar um conjunto de debates ou mesas-redondas para discuti-las. Convidem alunos de outras classes a participar desses eventos.

c) Organizem na escola uma espécie de fórum de discussões. Peçam a ajuda do professor para isso.

(FARACO, MOURA e MARUXO JR., 2013c, p. 351. Grifo nosso.) 
Considerando que todo o capítulo explora temáticas do universo político, a proposta do debate está ligada a uma prática social, em que o aluno tem a possibilidade de fazer uso de seus conhecimentos e participar de forma efetiva de uma discussão em uma situação escolar concreta.

Percebe-se, portanto, uma coerência de trabalho no capítulo analisado, que visa a uma consolidação de estudo, tendo como base temas polêmicos de interesse dos alunos. A sequência de debates proposta apresenta, assim, uma ligação entre teoria e prática e exerce uma função social significativa.

Do que foi exposto em relação à col.4-LPLI, podemos concluir que as atividades ora se apresentam como objeto de ensino, ora permitem o exercício de uma prática social que busca uma reflexão e análise dos usos efetivos que o debate permite na esfera escolar. 


\section{CONSIDERAÇÕES FINAIS}

O orador que escuta só sua própria voz, o professor que vê só seu manuscrito, é um mau orador, um mau professor. Eles paralisam a forma de seus enunciados, e com isto depreciam suas próprias intervenções.

(VOLOCHINOV, 2013b, p. 164)

Em busca de compreender de que forma os documentos oficiais orientam as atividades do livro didático de português do ensino médio, como o gênero debate é enfocado no interior do LDP-EM e de que forma essas propostas contribuem para uma tomada de posição dos sujeitos, para desenvolvimento de sua voz, trilhamos um caminho que nos levou a revisitarteorias, conhecer como o ensino médio está constituído e investigar quatro coleções didáticas.

No capítulo 1, a retomada histórica de projetos importantes na área da oralidade - Nurc e Gramática do Português culto falado no Brasil - deram-nos a dimensão de que muito material importante foi produzido para dar suporte à prática pedagógica desse eixo de ensino, não só os que esclarecem sobre as 
especificidades próprias do texto oral, como os encaminhamentos voltados para o ensino, propostos por diversos pesquisadores.

No capítulo 2, os estudos de alguns conceitos presentes nas obras do Círculo de Bakhtin,ajudaram-nos a construir uma visão de como o eixo da oralidade pode ser compreendido na teoria dialógica do discurso. Nesse aspecto, a visão de um sujeito histórico e social, que produz seu discurso em um tempo e em um espaço também sócio-históricos, aponta que a produção oral não pode ser entendida como simples interação face a face, mas que esse enunciado concreto é um posicionamento assumido. Assim, o valor axiológico do dizer evidencia um espaço importante a ser observado na prática pedagógica.

No capítulo 3, considerando nossa escolha pelo estudo do livro didático de português de ensino médio, investigamos mais detidamente que instrumentos legais regulam o funcionamento desse nível de ensino. Constamos, assim, que o documento Orientações Curriculares para o Ensino Médio (OCEM), publicado em 2006, apesar de ter sido publicado há 11 anos, é ainda o que dá base para a organização das séries finais da educação básica. Sua finalidade, como o próprio nome revela, é o de orientar, dar parâmetros para o trabalho docente, funcionando assim, no interior da esfera escolar, como um discurso internamente persuasivo (BAKHTIN, 1930-36/2015). Ele traz uma concepção de língua como instrumento de interação, voltado para o desenvolvimento de práticas sociais de produção e recepção de textos.

No que tange à publicação de livros didáticos, apontamos as especificidades do Edital de convocação do PNLD 2015, que apresentou os critérios que deveriam ser seguidos por editoras e autores para a aprovação neste programa, responsável pela avaliação dos livros didáticos adotados nas escolas públicas brasileiras. $\mathrm{Na}$ relação com as obras que foram produzidas, esse documento exerceu forma de discurso autoritário (BAKHTIN, 1930-36/2015), visto que o não seguimento das orientações implicou na reprovação de coleções didáticas por parte do governo.

Como produto final desse processo avaliativo, evidenciamos no capítulo 30 papel que o Guia de livros didáticos do ensino médio (BRASIL, 2014) exerce no interior do PNLD 2015, funcionamento como instrumento para auxiliar o professor na 
escolha da obra didática a ser adquirida. Evidenciamos, porém, que pesquisas já apontam que nem sempre essa finalidade é atendida na prática.

No capítulo 4, além de mostrar os critérios de análise, trouxemos uma caracterização do gênero debate, apresentando como ele pode ser observado na teoria dialógica do discurso. Para tanto, retomamos o conceito de gênero e sua constituição - forma composicional, conteúdo temático e estilo - e evidenciamos como as noções de discurso autoritário e discurso internamente persuasivo podem ser produtivas para a compreensão das vozes presentes no debate.

Considerando os estudos de Dolz, Schneuwly e Di Pietro (2004) em relação a esse gênero, evidenciamos que eles identificaram três tipos básicos: debate de opinião de fundo controverso, debate deliberativo e debate para resolução de problemas. Esses conceitos foram elucidativos para a leitura do corpus.

Após a caracterização do gênero, evidenciamos, no capítulo 4, que o corpus de nossa pesquisa foi constituído de quatro coleções didáticas aprovadas no PNLD 2015, sendo estas as mais adquiridas pelo governo.Mostramos também que duas delas - Novas palavras (col.2-NP) e Português: contexto, interlocução e sentido (col.3-PCIS) - apresentava seus conteúdos distribuídos em grandes eixos de ensino: literatura, gramática e produção de texto, e o trabalho com o gênero debate apresentava-se ligado tanto ao eixo de literatura, quanto ao de produção de texto. As outras duas coleções tinham uma configuração interna diferente das primeiras, pois não estavam divididas em três eixos: em Português linguagens (col.1-PL) cada capítulo, no interior de uma unidade, é que evidenciava se o estudo seria de literatura, de gramática ou de produção textual; em Língua Portuguesa: linguagem e interação (col.4-LPLI), as unidades eram temáticas, os capítulos focavam em um gênero e as seções internas apontavam para o trabalho com os aspectos literários, linguísticos e de produção textual.

Constituída a singularidade organizacional de cada obra, evidenciamos os diversos gêneros orais encontrados nas coleções - como canção, conversa telefônica, exposição oral, discurso político, seminário, mesa-redonda, telejornal, entre outros - e apontamos o motivo da escolha do debate: era o gênero presente nas quatro coleções e que foi tomado como objeto de ensino. 
No capítulo 5, analisamos coleção a coleção para compreender sua singularidade. A partir dessa leitura do corpus, conseguimos responder nossas perguntas de pesquisa.

A partir daprimeira delas - como os documentos oficiais orientam as atividades dos livros didáticos de português do ensino médio? - verificamos que a condução apresentada evidenciava propostas pautadas em uma concepção de língua enquanto interação, como é defendido nas OCEM (BRASIL, 2006). De forma geral, as propostas apresentavam uma situação de uso real em que o aluno era orientado a colocar seu ponto de vista e defendê-lo em um debate.

Em relação ao Edital (BRASIL, 2013b), todas as obras atenderam às suas indicações no que se refere ao número de páginas, à explicitação de fundamentação teórico-metodológica do manual do professor e à presença de atividades voltadas para o desenvolvimento de aspectos literários, linguísticos e de produção escrita e oral. No que tange ao trabalho com o eixo da oralidade - e mais especificamente do gênero debate -, percebemos algumas diferenças em relação à assimilação desse discurso.A col.1-PL e a col.4-LPLI assimilaram com maior propriedade a voz do documento pois apresentaram uma discussão sobre a construção textual do debate, das situações de uso e de uma escuta atenta, ainda que orientada a partir da discussão da gravação de um debate ou da análise de um debate transcrito. A col.2NP e a col.3-PCIS não responderam a inserção desses aspectos, ao menos em relação ao gênero debate, o qual era orientado, quase sempre a partir de uma indicação temática. A voz do edital ecoou com menor força no interior dessas duas coleções no que tange ao trabalho com o gênero analisado.

Nossa segunda pergunta de pesquisa - como o gênero debate foi apresentado nesses manuais? - teve uma resposta diversa, visto que o projeto didático apresentado evidenciou escolhas singulares da equipe responsável por cada coleção.

Na col.1-PL (CEREJA, MAGALHÃES, 2013d), o gênero debate foi proposto quatro vezes: uma no volume 1 e três no volume 3 . Em dois desses momentos, o gênero é tomado como objeto de ensino, estudado na íntegra de um capítulo. Para a realização desse estudo, a coleção apresenta debates transcritos e textos de outros gêneros (como artigo de opinião) visando a favorecer a discussão no momento de 
interação oral. Além disso, são apresentados quadros explicativos, com a situação do contexto mais imediato de produção, indicando os papéis dos interlocutores, a importância da divisão do tempo e os recursos linguísticos que podem servir de norte para a defesa de um ponto de vista. Segue-se a isso a apresentação do tema do debate, a orientação para que ele seja filmado e, posteriormente analisado e, com base no mesmo quadro, é orientada uma avaliação da produção. As outras duas propostas de debate estão ligadas ao uso efetivo do gênero no interior de uma prática social. Nessa obra, isso é feito na seção Projeto, ocasião em que, dentre outras ações, o aluno é levado a debater sobre temas previamente determinados.

Considerando que o estudo dos aspectos de organização e de produção do gênero já havia sido realizado nas primeiras propostas, as duas últimas vêm ao encontro de consolidar esses conhecimentos em "práticas sociais de uso da língua", conforme é orientado pelas OCEM (BRASIL, 2006, p. 30).

$\mathrm{Na}$ col.2-NP (AMARAL et al, 2013d) há um número mais expressivo de propostas de debate - dezesseis - que ocorrem sempre na seção $E$ mais, distribuída ao longo da obra. A maioria delas, porém, não é tomada como objeto de ensino, visto que ela está constituída quase sempre por uma proposição temática, sem indicação de procedimentos para sua concretização. $O$ movimento metodológico de trabalho com o gênero é a realização de uma leitura ou pesquisa sobre um assunto explicitado no LDP-EM e a posterior realização de um debate, que entra na obra como prática social. Esse trabalho está relacionado nessa coleção em grande parte com o eixo da literatura, visto que dez delas está ligada a uma discussão associada aos estudos literários propostos na obra. Assim, apesar de um número expressivo de atividades, o direcionamento apresentado configura-se de modo bastante diferente do que foi observado na primeira coleção.

Na col.3-PCIS (ABAURRE, ABAURRE, PONTARA, 2013d), a presença do gênero debate indicada no livro do aluno ocorre apenas duas vezes e somente no volume 1, nas seções "Jogo de ideias" e "Produção oral". Em nossa análise, levamos em conta também quatro momentos em que o livro do professor traz uma orientação para o debate. Assim, nessa coleção, foram consideradas seis propostas de trabalho com esse gênero. 
Nas atividades indicadas no livro do aluno, uma ligada ao eixo de literatura e outra ao eixo de produção textual -a organização da proposta é feita com uma contextualização da situação sobre a qual se debaterá - de um lado as diferentes visões do processo de colonização e, de outro, os problemas do bullying - seguida por questões motivadoras para a discussão. Nos dois casos, as atividades são parte de uma etapa prevista no interior da obra: na literatura, a consolidação dos estudos apresentados; na produção textual, a preparação para a escrita de um anúncio.

Nas orientações apresentadas no livro do professor, duas estão ligadas ao boxe "De olho no filme" e trazem encaminhamentos semelhantes: assistir ao filme e debater sobre a temática que ele aborda. As outras duas estão em seções distintas: uma refere-se à seção "Interações" e orienta a discussão sobre racismo a partir da leitura de uma letra de canção e de um cartum; a outra à seção "Conexões: encontro de linguagens" (que apresenta uma lista de livros, filmes, sites e músicas ao final do capítulo), em que se indica a realização de um debate baseado nas apreciações que os alunos apresentarem sobre um dos filmes assistidos. Apenas esta última está localizada no caderno de produção textual, as três anteriores são proposições do caderno de literatura.

Nossa análise evidenciou que na col.3-PCIS o gênero debate é pouco priorizado para o estudo sistemático, sendo usado apenas como uma prática social que atende à necessidade de interação em determinadas situações de uso da língua na esfera escolar.

Na col.4-LPLI (FARACO, MOURA, MARUXO JR., 2013d), há uma evidente valoração do estudo da linguagem oral, visto que em todos os capítulos é proposta uma reflexão sobre o eixo da oralidade, seja pela discussão da presença de hesitação, reformulação, troca de turnos etc em alguns textos transcritos, seja pela indicação de produção de gêneros orais (mesa redonda, entrevista oral, discurso político) tomados como objeto de ensino.

O gênero debate é apresentado nove vezes ao longo da obra.

No volume 1, ele é estudado em três capítulos consecutivos, em que se propõe, na seção "Linguagem oral", uma relação com os gêneros principais estudados em cada um deles: artigo de opinião, editorial e carta do leitor. Apesar de ser uma seção, o gênero é tomado como objeto de ensino, pois o aluno é estimulado 
a refletir sobre suas características, produzir o debate a partir de um tema proposto, gravá-lo, analisá-lo e refletir sobre as mudanças necessárias em produções futuras. É, portanto, uma condução que instiga o aluno a pensar sobre e não apenas a reproduzir uma ação de forma automática.

No volume 2, as duas propostas indicam ações semelhantes: o aluno deve pesquisar sobre um determinado tema e, depois, debater sobre ele. No volume 3, as quatro propostas finais estão ligadas a uma sistematização de conhecimentos ligados a outros gêneros. Assim, a escrita de um ensaio, a análise de uma entrevista é tomada como ponto de partida para a realização do debate. Tanto no volume 2, quanto no 3, percebemos o uso do debate como uma prática social.

As singularidades de cada coleção evidenciam que o gênero oral no LDPEM é ora tratado como objeto de ensino, ora como prática social, sendo que esta última é mais recorrente no conjunto das propostas. Verifica-se, assim, a especificidade do trabalho com esse gênero no ensino médio.

Nossa terceira e última pergunta de pesquisa - como se dá ou não o trabalho efetivo para a tomada de posição dos sujeitos no processo da atividade argumentativa no ensino médio? - levou-nos a perceber que temas muito direcionados ou que estão ligados a uma leitura que aborda um só ponto de vista tendem a reduzir a possibilidade de tomada de posição dos sujeitos no interior do ato, levando-os a um apagamento de sua voz, visto que eles tendem a reproduzir o discurso primeiro (do texto lido, do conteúdo didático estudado etc.). Da mesma forma, a proposição de temas polêmicos, a indicação de leituras e de pesquisas mais abertas, que possibilitam uma reflexão, funcionam de maneira mais efetiva para a construção de uma postura mais ativa.

Em síntese, as análises demonstraram que a proposição de temas frouxos e atividades muito direcionadas apontam para a possibilidade de silenciamento da voz do aluno, enquanto a presença de temas polêmicos e a liberdade para apresentação de pontos de vista diversos favorecem a tomada de posição.

Nossos estudos teóricos e a leitura constante do corpus nos levaram a perceber a presença das vozes em diálogo no interior do livro didático de português e a importância da relação entre o dado e o criado quando tratamos do LDP-EM, visto que embora haja uma orientação didática dada, é na singularidade do evento 
que os sujeitos ativos podem dar novos ares à proposta, a partir do criado. É nesse sentido que emerge nossa compreensão de livro didático como acontecimento, tese trazida à luz no capítulo 2 deste trabalho.

O movimento de entender o livro didático como um acontecimento nos permite compreender que embora nele haja uma orientação de trabalho, cabe ao professor atualizá-lo, ampliando ainda mais seu potencial de criação.

Em diversos momentos da análise observamos quanto é significativo o papel deste na mediação das propostas, visto ser ele a ponte necessária para atualizar as atividades didáticas, contribuindo para que o aluno efetivamente tenha voz.

Nas atividades de debate, por exemplo, o docente, atento à realidade que 0 circunda e ciente dos interesses de seus alunos de ensino médio, poderia propor novas discussões a partir da análise de debates televisivos e radiofônicos concretos. Ou, para vivenciar uma situação de uso, orientar o aluno a buscar vivenciar a experiência de assistir a um debate ao vivo e, se possível, participar, interagindo com os debatedores.Programas de entrevista também poderiam ser utilizados como mote para estimular uma reflexão acerca de um tema polêmico. Há diversos programas jornalísticos que de alguma forma podem contribuir para discussões dessa natureza ${ }^{85}$.

É preciso ter claro, no entanto, o que deve ser observado. Nesse aspecto, não devem ser deixadas de lado as contribuições empreendidas quanto às especificidades da oralidade, como demonstramos no capítulo 1. Assim, compreender como ocorrem as hesitações, interrupções, retomadas, correções, pausasetc, e seu marcador linguístico é significativo.

Entendemos, porém, que um passo adiante pode ser dado em um estudo do gênero debate em situação real: levar o aluno a refletir sobre os efeitos de sentido que as estratégias próprias do modo de produção oral geram no discurso como um todo. Algumas questões, nesse sentido, poderiam ser formuladas aos alunos:

\footnotetext{
${ }^{85}$ Apenas para exemplificar, cito os programas da Rede Globo de televisão: "Altas horas", em que os jovens participam fazendo perguntas ou colocando sua opinião sobre determinado assunto, o "Encontro com Fátima Bernardes", que tem igualmente permitido a participação da plateia, e o "Conversa com Bial", em que há um movimento em que os próprios entrevistados podem interagir entre si. Sejam quais forem os programas escolhidos, a ideia é que eles possam ter diferentes formatos, para que se observem aspectos diversificados a partir deles.
} 
(1) Qual o sentido da pausa, em determinado momento do debate?

(2) Que função valorativa exerce uma determinada repetição no contexto estudado?

(3) De que forma os interlocutores marcam seu lugar social, evidenciando a relação de poder entre eles?

(4) Que estratégias são utilizadas por eles para evidenciar os jogos de poder próprios desse momento de interação?

(5) As modalizações discursivas, comuns em momentos de debate, têm que efeito de sentido para a imagem de todos os envolvidos?

Nas atividades em que o debate foi tomado como objeto de ensino nas quatro coleções de ensino médio analisadas nesse trabalho, mostramos como os encaminhamentos quase sempre orientam a observação do gênero no que tange ao tema que deve ser discutido e à situação que envolve o momento de produção (apontando, por exemplo, o papel de cada um, o tempo de fala, os recursos de linguagem etc).

Práticas como essa têm seu valor no sentido de orientar o trabalho inicial do aluno, mas nos preocupa o fato de elas serem potencialmente prescritivas, visto que podem engessar a ação dos participantes em um momento real de interação.

É nesse sentido que entendemos que as perguntas apontadas acima podem trazer um novo caminho para o trabalho com o gênero debate, estimulando todos os participantes a estarem atentos aos jogos de poder que envolvem essa prática.

Se o LDP-EM propuser análises que estimulem uma reflexão sobre os sujeitos que enunciam, sobre os interesses e jogos de poder envolvidos na esfera em que se deu o debate e sobre como cada interlocutor assume sua voz autoral nas situações vivenciadas, teremos ampliado a discussão desse ensino em caminho de algo menos fechado, visto que não há respostas prontas. É apenas no acontecimento em que elas serão de fato compreendidas.

Reforçamos mais uma vez a relevância do professor nesse processo, o que pode indicar também a necessidade de cursos de capacitação ${ }^{86}$ para ajudá-lo a

${ }^{86}$ Embora este não seja o enfoque deste trabalho, acreditamos que os resultados desta pesquisa apontam para novos estudos, confirmando-se, assim, o que já dizia Bakhtin sobre o enunciado ter um acabamento - como essa tese neste momento - mas nunca estar acabado em si, uma vez que sempre projeta novos discursos. 
compreender como estimular seu aluno a ter um olhar voltado não apenas para o tema do debate ou o reconhecimento da situação enunciativa, mas, fundamentalmente, para perceber que a tomada de posição só acontece de fato no diálogo com o grande tempo, ou seja, com a história e a cultura que nos levam a dizer e, consequentemente, a agir desta ou daquela forma.

Talvez o passo a frente de que tratamos acima seja justamente atingir a compreensão da valoração partilhada da situação, visto que o LDP-EM, de alguma forma, coloca para o aluno tanto o horizonte espacial partilhado - quando descreve a proposta e a cena enunciativa - quanto o conhecimento e a compreensão comum da situação. Esse diálogo fica apenas no sentido estrito (do eu-para-o-outro). O que nos interessa é que esse olhar se amplie do outro-para-mim.

Defendemos, pois, que para além da descrição dos interlocutores do debate e da apresentação do tema a ser discutido, as propostas do LDP-EM criem condições para que os alunos reconheçam a tensão e os embates próprios de qualquer enunciado e, a partir disto, estimulem os alunos a efetivamente assumirem sua própria voz. 


\section{REFERÊNCIAS}

ABAURRE, Maria Luiza M.; ABAURRE, Maria Bernardete M.; PONTARA, Marcela. Português: contexto, interlocução e sentido. Ensino Médio, 1ํ ano. 2.ed. São Paulo: Moderna, 2013a.

2ำ ano. 2.ed. São Paulo: Moderna, 2013b.

Português: contexto, interlocução e sentido. Ensino Médio, Português: contexto, interlocução e sentido. Ensino Médio, $3^{\circ}$ ano. 2.ed. São Paulo: Moderna, 2013c.

2.ed. São Paulo: Moderna, 2013d. v. 1, 2 e 3.

.Português: contexto, interlocução e sentido. Ensino Médio.

ABAURRE, Maria Bernardete Marques. (org.). Gramática do português culto falado no Brasil. Vol. II - A construção fonológica da palavra. São Paulo: Contexto, 2013. 
; RODRIGUES, Ângela Cecília S. (orgs.). Gramática do português falado. Vol. VIII - Novos estudos descritivos. Campinas: Editora da Unicamp, 2003.

AMARAL, Emília. (et al).Novas palavras. Ensino Médio, 1ำ ano. 2.ed. São Paulo: FTD, 2013a.

.Novas palavras. Ensino Médio, $2^{\circ}$ ano. 2.ed. São Paulo: FTD, 2013b.

.Novas palavras. Ensino Médio, 3ํano. 2.ed. São Paulo: FTD, 2013c.

.Novas palavras. Ensino Médio. 2.ed. São Paulo: FTD, 2013d. v. 1, 2 e 3.

ANDRADE, Maria Lúcia da C. V. de O. A digressão como estratégia discursiva na produção de textos orais e escritos. In: PRETI, Dino. (org.) Fala e escrita em questão. 3.ed. (Projetos paralelos - NURC/SP, 4). São Paulo: Associação Editorial Humanitas, 2006. p. 99-128.

ANTUNES, Irandé. Aula de português: encontro \& interação. São Paulo: Parábola editorial, 2003.

AUTHIER-REVUZ, Jaqueline. Palavras incertas: as não coincidências do dizer. Campinas, SP: Unicamp, 1998.

BAGNO, Marcos. Dramática da língua portuguesa: tradição gramatical, mídia \& exclusão social. São Paulo: Loyola, 2000.

editorial, 2011.

Gramática pedagógica do português brasileiro. São Paulo: Parábola

. Nada na língua é por acaso: por uma pedagogia da variação linguística.

São Paulo: Parábola, 2007.

. Preconceito linguístico: o que é, como se faz. São Paulo: Loyola, 1999.

BAJTIN, Mijail. Hacia una filosofíadelacto ético. In: Hacia una filosofíadelacto ético. De los borradores y otros escritos. Rubi: Anthropos; San Juan: Universidad de Puerto Rico, 1997, p. 7-81.

BAKHTIN, Mikhail. Estética da criação verbal. 6.ed. Trad. Paulo Bezerra. São Paulo: Martins Fontes, 1979/2011a.

. O tempo e o espaço nas obras de Goethe. In: Estética da Criação Verbal. 6.ed.Trad. Paulo Bezerra. São Paulo: Martins Fontes, 1979/2011b.

Metodologia das ciências humanas. In: Estética da Criação Verbal. 6.ed.Trad. Paulo Bezerra. São Paulo: Martins Fontes, 1979/2011c. $\overline{53 / 2016}$

Os gêneros do discurso. Trad. Paulo Bezerra. São Paulo: Editora 34, 1952-

- Para uma filosofia do ato responsável. Trad. Valdemir Miotello\& Carlos Alberto Faraco. São Carlos, SP: Pedro \& João editores, 1920-24/2010. 
. Questões de literatura e de estética: a teoria do romance. São Paulo: Unesp/Hucitec, 1990.

Problemas da poética de Dostoiévski. Trad. Paulo Bezerra. 4.ed. Rio de Janeiro: Forense-Universitária, 1929/2008.

Teoria do romance l: a estilística. Trad. Paulo Bezerra. São Paulo: Editora 34, 1930-36/2015.

BARROS-MENDES, Adelma das Neves Nunes. A linguagem oral nos livros didáticos de Língua Portuguesa do Ensino Fundamental - $3^{\circ}$ e $4^{\circ}$ ciclos: algumas reflexões. 2005. 211p. Tese (Doutorado em Linguística Aplicada e Estudos da Linguagem). Programa de Estudos Pós-graduados em Linguística Aplicada e Estudos da Linguagem, Pontifícia Universidade Católica de São Paulo. São Paulo, 2005.

BATISTA, Antônio Augusto Gomes. A avaliação dos livros didáticos: para entender o Programa Nacional do Livro Didático (PNLD). In: BATISTA, Antônio Augusto Gomes.; ROJO, Roxane. Livro Didático de Língua Portuguesa, letramento e cultura da escrita. Campinas, SP: Mercado das Letras, 2003. p. 25-67.

.; ROJO, Roxane; ZÚÑIGA, Nora Cabrera. Produzindo livros didáticos em tempo de mudança (1999-2002). In: COSTA VAL, Maria da Graça; MARCUSCHI, Beth. (orgs.). Livros didáticos de língua portuguesa: letramento, inclusão e cidadania. 1. reimp. Belo Horizonte: Ceale; Autêntica, 2008. p. 47-72.

BORTONI-RICARDO, Stella Maris. Educação em língua materna: a sociolinguística na sala de aula. São Paulo: Parábola, 2004.

BRAIT, Beth. O processo interacional. In: PRETI, Dino. (org.). Análise de textos orais.São Paulo: Humanitas/FFLCH/USP, 1993, Projetos paralelos - NURC-SP, v. 1; 6.ed., 2003.

BRASIL. Ministério da Educação e da Cultura. Secretaria de Educação Básica. Diretoria de Currículos e Educação Integral. Diretrizes Curriculares para o Ensino Médio. In:Diretrizes Curriculares Nacionais Gerais da Educação Básica. Brasília: MEC/SEB/DICEI, 2013a. Disponível em <http://portal.mec.gov.br/docman/julho2013-pdf/13677-diretrizes-educacao-basica-2013-pdf/file>. Acesso em 10/02/2017.

. Edital de convocação para o processo de inscrição e avaliação de obras didáticas para o Programa Nacional do Livro Didático - PNLD 2015.81p. Brasília: MEC/SEB/FNDE: 2013b. Disponível em <http://www.fnde.gov.br/programas/livro-didatico/livro-didatico-editais/item/4032pnld-2015>. Acesso em 03/10/2015.

Guia de livros didáticos - PNLD 2015. Brasília: MEC/SEB/FNDE: 2014. Disponível em <http://www.fnde.gov.br/programas/livro-didatico/guias-dopnld/item/5940-guia-pnld-2015>. Acesso em 04/10/2015. apresentacao>. Acesso em 05/10/2015. 
Portal FNDE: Programa Nacional do Livro Didático - Histórico do PNLD. 2017a. Disponível em <http://www.fnde.gov.br/programas/programas-dolivro/livro-didatico/historico>. Acesso em 10/03/2017.

\section{Funcionamento}

Portal FNDE: Programa Nacional do PNLD. 2017b.

do Livro Didático -
Disponível em $<$ http://www.fnde.gov.br/programas/programas-do-livro/livrodidatico/funcionamento>. Acesso em 10/03/2017.

.Lei de Diretrizes e Bases da Educação Nacional. LDB $\mathrm{n}^{\circ}$

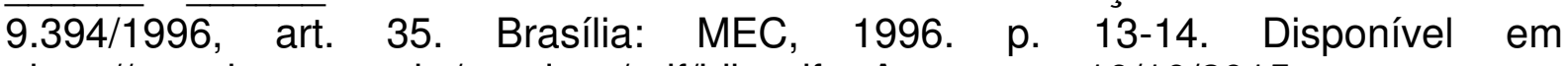
$<$ http://portal.mec.gov.br/arquivos/pdf/ldb.pdf>. Acesso em 10/10/2015.

Secretaria de Educação Fundamental. Parâmetros Curriculares Nacionais: primeiro e segundo ciclos do ensino fundamental - Língua Portuguesa. Brasília: MEC/SEF, 1997.

Secretaria de Educação Fundamental. Parâmetros Curriculares Nacionais: terceiro e quarto ciclos do ensino fundamental - Língua Portuguesa. Brasília: MEC/SEF, 1998.

Secretaria de Educação Média e Tecnológica. Parâmetros Curriculares Nacionais: ensino médio. Brasília: MEC, 2000.

Secretaria de Educação Média e Tecnológica. PCN+ Ensino Médio: Orientações educacionais complementares aos Parâmetros Curriculares Nacionais. Linguagens, códigos e suas tecnologias. Brasília: MEC, 2002.

Secretaria da Educação Básica. Orientações curriculares para o ensino médio: Linguagens, códigos e suas tecnologias. v.1. Brasília: MEC, 2006. 239p. Disponível em: <http://portal.mec.gov.br/seb/arquivos/pdf/book_volume_01_internet.pdf>. Acesso em 10/02/2016.

Secretaria de Educação Básica. Diretrizes Curriculares Nacionais para o Ensino Médio:Resolução CEB $n^{\circ} 3$, de 26 de Junho de 1998. Brasília: MEC/SEB, $\quad 1998 . \quad$ Disponível em <http://portal.mec.gov.br/seb/arquivos/pdf/res0398.pdf>. Acesso em 10/02/2017.

. Fundo Nacional de Desenvolvimento da Educação - FNDE. Programas: PNLD. Disponível em <http://www.fnde.gov.br/programas/livro-didatico/ivro-didaticoapresentacao >. Acesso em 02/10/2015.

PNLD 2015 - Coleções mais distribuídas por componente curricular Português. Disponível em <http://www.fnde.gov.br/programas/livrodidatico/livro-didatico-dados-estatisticos>. Acesso em 05/03/2016.

BUNZEN JR., Clécio dos Santos. Dinâmicas discursivas na aula de Português: os usos do Livro Didático e projetos didáticos autorais. Campinas, SP: Unicamp. Tese. (Doutorado em Linguística Aplicada), 2009. 
. O gênero "debate" em três coleções de Língua Portuguesa aprovadas no PNLD 2011. In: Eutomia, Recife, 11 (1): p. 362-385, Jan./Jun. 2013.

- ROJO, Roxane. Livro didático de Língua Portuguesa como gênero do discurso: autoria e estilo. In: COSTA VAL, Maria da Graça. MARCUSCHI, Beth. (orgs.) Livros didáticos de língua portuguesa: letramento, inclusão e cidadania. Belo Horizonte: Ceale; Autêntica, 2008. p. 73-117.

CAMPOS, Maria Inês Batista. A construção da identidade nacional nas crônicas da revista do Brasil. São Paulo: Olho d’Água/Fapesp, 2011.

. A questão da arquitetônica em Bakhtin: um olhar para materiais didáticos de língua portuguesa. Revista Filologia e linguística portuguesa. n.14(2), p. 247-263, 2012. São Paulo: DLCV, FFLCH-USP, 2012.

CAMPOS, Maria Tereza Rangel Arruda. Edital de compra de livro de língua portuguesa para o ensino médio: uma arena discursiva de muitas vozes. 2014. 290p. Dissertação (Mestrado em Linguística Aplicada e Estudos da Linguagem). Programa de Estudos Pós-graduados em Linguística Aplicada e Estudos da Linguagem, Pontifícia Universidade Católica de São Paulo. São Paulo, 2014.

CASTILHO, Ataliba Teixeira de. A língua falada no ensino de português. 3.ed. São Paulo: Contexto: 2000.

. A nova gramática do Português Brasileiro. Revista Philologus, ano 16, n.47. Rio de Janeiro: CiFEFil, maio/ago, 2010. Disponível em $<$ http://filologia.dominiotemporario.com/revista/47/08.pdf>. Acesso em 07/09/2014.

- Desafio nos estudos da Língua Falada. São Paulo: Museu da Língua Portuguesa, $2014 . \quad$ Disponível em <http://www.museudalinguaportuguesa.org.br/files/m/p/texto_37.pdf>. Acesso em 30/10/2014.

disponibilizado pelo autor).

Descrevendo o Português Brasileiro. Conferência. Inédito. (Arquivo . (org.). Gramática do português falado. Vol. I - A ordem. Campinas: Editora da Unicamp; São Paulo: Fapesp, 1990; 4.ed., 2002.

. (org.). Gramática do português falado. Vol. III - As abordagens. Campinas: Editora da Unicamp; São Paulo: Fapesp, 1993; 3.ed., 2002.

.; BASÍLIO, Margarida. (orgs.). Gramática do português falado. Vol. IV Estudos descritivos. Campinas: Editora da Unicamp; São Paulo: Fapesp, 1996; 2.ed., 2002.

CAVALCANTE, Marianne C. B.; MELO, Cristina T. V. Oralidade no ensino médio: em busca de uma prática. In: BUNZEN, Clécio. MENDONÇA, Márcia (orgs.) Português no ensino médio e formação do professor. São Paulo: Parábola editorial, 2006. p. 181-198. 
CEREJA, William Roberto.; MAGALHÃES, Thereza Anália Cochar. Português: linguagens. Ensino Médio, 1ำ ano. 9.ed. São Paulo: Saraiva, 2013a.

Saraiva, $2013 b$.

Português: linguagens. Ensino Médio, 2ํㅜ ano. 9.ed. São Paulo:

Português: linguagens. Ensino Médio, $3^{\circ}$ ano. 9.ed. São Paulo:

$\overline{\text { Saraiva }}, \overline{2013 c .}$

Português: linguagens. Ensino Médio. 9.ed. São Paulo: Saraiva, 2013d. v. 1, 2 e 3.

CHAFE, Wallace. Linguistic diferences produces by diferences between speaking and writing. In: OLSON, David R.; TORRANCE, Nancy; HILDYARD, Angela. (eds.). Literacy, Language, and Learning: The Nature and Consequences of Reading and Writing. Cambrigde: Cambridge University Press, 1985.

CORRÊA, Manoel Luiz Gonçalves. Encontros entre prática de pesquisa e ensino: oralidade e letramento no ensino da escrita. Revista Perspectiva, Florianópolis, v.28, n.2, p. 625-648, jul./dez. 2010. Disponível em $<$ https://periodicos.ufsc.br/index.php/perspectiva/article/view/2175-

795X.2010v28n2p625>. Acesso em 20/03/2014.

COSTA, Débora Amorim Gomes da.Livros Didáticos de Língua Portuguesa: propostas didáticas para o ensino da linguagem oral. 2006. 106p. Dissertação (Mestrado em Educação). Programa de Estudos Pós-graduados em Educação, Universidade Federal de Pernambuco. Recife, 2006.

COSTA-MACIEL, Débora Amorim Gomes da.Oralidade e ensino: saberes necessários à prática docente. Recife: Edupe, Editora Universidade de Pernambuco, 2013.

DOLZ, Joaquim. SCHNEUWLY, Bernard. Pourunenseignement de l'oral: initiationauxgenresformels à l'école. Paris: ESF Éditeur, 1998.

DOLZ, Joaquim. SCHNEUWLY, Bernard. Gêneros orais e escritos na escola. Campinas, SP: Mercado de Letras, 2004a.

.Gêneros e progressão em expressão oral e escrita: elementos para reflexões sobre uma experiência suíça (francófona). In: ROJO, Roxane. CORDEIRO, Glaís. (orgs.) Gêneros orais e escritos na escola. Campinas, SP: Mercado de Letras, 2004b. p. 41-70.

NOVERRAZ, Michèle. Sequências didáticas para o oral e a escrita: apresentação de um procedimento. In: ROJO, Roxane. CORDEIRO, Glaís. (orgs.) Gêneros orais e escritos na escola. Campinas, SP: Mercado de Letras, 2004. p. 95128.

. HALLER, Sylvie. O oral como texto: como construir um objeto de ensino. In: ROJO, Roxane. CORDEIRO, Glaís. (orgs.) Gêneros orais e escritos na escola. Campinas, SP: Mercado de Letras, 2004. p. 149-185. 
- DE PIETRO, Jean-François. Relato da elaboração de uma sequência: o debate público. In: ROJO, Roxane. CORDEIRO, Glaís. (orgs.) Gêneros orais e escritos na escola. Campinas, SP: Mercado de Letras, 2004. p.247-278.

. (et. al.). A exposição oral. In: ROJO, Roxane. CORDEIRO, Glaís. (orgs.) Gêneros orais e escritos na escola. Campinas, SP: Mercado de Letras, 2004. p. 215-246.

FARACO, Carlos Alberto. Linguagem \& diálogo: as ideias linguísticas do círculo de Bakhtin. São Paulo: Parábola Editorial, 2009.

FARACO, Carlos Emílio.; MOURA, Francisco Marto de.; MARUXO JR., José Hamilton. Língua Portuguesa: linguagem e interação. Ensino Médio, $1^{\circ}$ ano. 2.ed. São Paulo: Ática, 2013a.

20 ano. 2.ed. São Paulo: Ática, 2013b.

Língua Portuguesa: linguagem e interação. Ensino Médio, Língua Portuguesa: linguagem e interação. Ensino Médio, 3a ano. 2.ed. São Paulo: Ática, 2013c.

2.ed. São Paulo: Ática, 2013d. v. 1, 2 e 3.

Língua Portuguesa: linguagem e interação. Ensino Médio.

FÁVERO, Leonor Lopes; ANDRADE, Maria Lúcia C.V.O.; AQUINO, Zilda G. O. 8.ed. Oralidade e escrita: perspectivas para o ensino de língua materna. São Paulo: Cortez, 2012.

portuguesa. In: ELIAS, Vanda Maria. Ensino de Língua Portuguesa: oralidade, escrita e leitura. São Paulo: Contexto, 2014. p. 13-27.

GERALDI, João Wanderlei. Introdução: O mundo não nos é dado, mas construído. In: VOLOCHINOV, Valentin Nikolaevitch. A construção da enunciação e outros ensaios. São Carlos: Pedro \& João Editores, 2013. p. 7-27.

HILGERT, José Gaston. O falante como observador de suas próprias palavras: retomando aspectos metadiscursivos na construção do texto falado. In: PRETI, Dino. (org.). Oralidade em diferentes discursos. São Paulo: Associação editorial humanitas, 2006, Projetos paralelos - NURC-SP, v. 8.

ILARI, Rodolfo. (org.). Gramática do português falado. Vol. II - Níveis de análise linguística. Campinas: Editora da Unicamp; São Paulo: Fapesp, 1992; 4.ed. rev., 2002.

; NEVES, Maria Helena de Moura. (orgs.).Gramática do português culto falado no Brasil. Vol. II: Classes de palavras e processos de construção. Campinas, SP: Editora da Unicamp, 2009.

. (org.).Gramática do português culto falado no Brasil. Vol. III: Palavras de classes aberta. São Paulo: Contexto, 2014. 
; BASSO, Renato. O português da gente: a língua que estudamos, a língua que falamos. São Paulo: Contexto, 2006.

INNOCÊNCIO, Mariângela Tostes. A cultura oral na escola escrita. 2009. Disponível em

<http://www.anpae.org.br/iberoamericano2012/Trabalhos/MariangelaTostesInnocenc io_res_int_GT1.pdf>. Acesso em 15/03/2015.

JUBRAN, Clélia Cândida Abreu Spinardi. A perspectiva textual-interativa. In: JUBRAN, Clélia Cândida Abreu Spinardi.; KOCH, IngedoreGrunfeld. (orgs.). Gramática do português culto falado no Brasil. Vol. I: A construção do texto falado. Campinas, SP: Editora da Unicamp, 2006a.p. 27-36.

; $\mathrm{KOCH}$, IngedoreGrunfeld. (orgs.). Gramática do português culto falado no Brasil, Vol. I: A construção do texto falado. Campinas, SP: Editora da Unicamp, 2006.

KATO, Mary A. (org.). Gramática do português falado. Vol. V: Convergências. Campinas: Editora da Unicamp; São Paulo: Fapesp, 1996; 2.ed. rev., 2002.

; NASCIMENTO, Mílton do. (orgs.). Gramática do português culto falado no Brasil: Vol. III: A construção da sentença. Campinas, SP: Editora da Unicamp, 2009.

KERBRAT-ORECCHIONI, Catherine. (1996) Análise da Conversação: princípios e métodos. São Paulo: Parábola editorial, 2006.

$\mathrm{KOCH}$, IngedoreGrunfeld Villaça. Especificidade do texto falado. In: JUBRAN, Clélia Cândida Abreu Spinardi\& KOCH, IngedoreGrunfeld Villaça. Gramática do português culto falado no Brasil. Vol. 1: A construção do texto falado. Campinas: Editora Unicamp, 2006. p. 39-46.

. (org.). Gramática do português falado. Vol. VI - Desenvolvimentos. Campinas: Editora da Unicamp; São Paulo: Fapesp, 1996; 2.ed. rev., 2002.

LEITE, Marli Quadros. Oralidade, escrita, gênero e mídia: entrelaçamentos. In: PRETI, Dino. (org.). Oralidade em diferentes discursos. São Paulo: Associação editorial humanitas, 2006, Projetos paralelos - NURC-SP, v. 8.

MAGALHÃES, Tânia Guedes. Concepção de oralidade: a teoria nos PCN e no PNLD x a prática nos livros didáticos. 2007. 211p. Tese (Doutorado em Letras). Programa de Estudos Pós-graduados em Letras, Universidade Federal Fluminense. Niterói, RJ, 2007.

. Oralidade em documentos oficiais do Ensino Médio. Linhas Críticas: revista da Faculdade de Educação da UnB. Brasília-DF. v.17, n.32, p. 151-162, jan./abr. 2011.

em: <http://periodicos.unb.br/index.php/linhascriticas/article/view/3984/3361>. Acesso em 20/04/2014.

MARCUSCHI, Luiz Antônio. Da fala para a escrita: atividades de retextualização. 10.ed. São Paulo: Cortez, 2010. 
Fenômenos intrínsecos da oralidade: hesitação. In: JUBRAN, Clélia Cândida Abreu Spinardi\& KOCH, IngedoreGrunfeld Villaça. Gramática do português culto falado no Brasil. Vol. 1: A construção do texto falado. Campinas: Editora Unicamp, 2006. p. 47-70.

- Letramento e oralidade no contexto das práticas sociais e eventos comunicativos. In: SIGNORINI, Inês. Investigando a relação oral/escrito. Campinas: Mercado de Letras, 2001. p. 23-50.

. Oralidade e ensino de língua: uma questão pouco "falada". In: DIONíSIO, Ângela Paiva; BEZERRA, Maria Auxiliadora. O livro didático de Português: múltiplos olhares. 2.ed. Rio de Janeiro: Lucerna, 2003.

Produção textual, análise de gêneros e compreensão. São Paulo: Parábola editorial, 2008.

MEDVIÉDEV, PáveINikoláievitch. O método formal nos estudos literários: introdução crítica a uma poética sociológica. São Paulo: Contexto, 1928/2012.

MELO, Cristina Teixeira Vieira de.; MARCUSCHI, Beth.; CAVALCANTE, Marianne Bezerra. Esclarecendo o trabalho com a oralidade: uma proposta didática. In: LEAL, Telma Ferraz.; GOIS, Siane. (orgs.). A oralidade na escola: a investigação do trabalho docente como foco de reflexão. Belo Horizonte: Autêntica Editora, 2012. p. 95-114.

MORSON, Gary Saul. EMERSON, Caryl. Mikhail Bakhtin: criação de uma prosaística. Trad. Antonio de Pádua Danesi. São Paulo: Edusp, 2008.

NASCIMENTO, Elvira Lopes do. Debate na sala de aula: gênero catalizador para aprendizagens e desenvolvimento. In: BUENO, Luzia. COSTA-HÜBES (orgs.). Gêneros orais no ensino. Campinas, SP: Mercado de Letras, 2015. p. 197-227.

NEVES, Maria Helena de Moura. (org.). Gramática do português falado. Vol. VII: Novos estudos. Campinas: Editora da Unicamp; São Paulo: Humanitas, 1999; 2.ed., 2002.

OLIVEIRA, Márcia Andrea Almeida de. O ensino de Língua Portuguesa: usos do livro didático, objetos de ensino e gestos profissionais. 2013. 407p. Tese (Doutorado em Linguística Aplicada). Departamento de Linguística Aplicada do Instituto de Estudos da Linguagem, Universidade Estadual de Campinas. Campinas, SP, 2013.

PRETI, Dino. (org.). Análise de textos orais.São Paulo: Humanitas/FFLCH/USP, 1993, Projetos paralelos - NURC-SP, v. 1; 6.ed., 2003.

. O discurso oral culto. São Paulo: Associação editorial humanitas, 1997, Projetos paralelos - NURC-SP, v. 2; 3.ed., 2005.

. Estudos de língua falada: variações e confrontos. São Paulo: Associação editorial humanitas, 1998, Projetos paralelos - NURC-SP, v. 3; 2.ed., 2006.

Fala e escrita em questão. São Paulo: Associação editorial humanitas, 2000, Projetos paralelos - NURC-SP, v. 4; 3.ed., 2006. 
. Interação na fala e na escrita. São Paulo: Humanitas/FFLCH/USP, 2002, Projetos paralelos - NURC-SP, v. 5.

Léxico na língua oral e na escrita. São Paulo: Humanitas/FFLCH/USP, 2003, Projetos paralelos - NURC-SP, v. 6.

Diálogos na fala e na escrita. São Paulo: Humanitas, 2005, Projetos

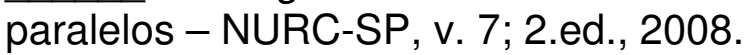

Oralidade em diferentes discursos. São Paulo: Associação editorial humanitas, 2006, Projetos paralelos - NURC-SP, v. 8. $\overline{\mathrm{SP}, \mathrm{v} .} 9$.

. Cortesia verbal. São Paulo:Humanitas, 2008, Projetos paralelos - NURC-

Oralidade em textos escritos. São Paulo: Humanitas, 2009, Projetos paralelos - NURC-SP, v. 10.

Variações na fala e na escrita. São Paulo: Humanitas, 2011, Projetos

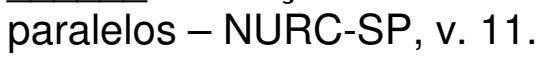

. Comunicação na fala e na escrita. São Paulo: Humanitas, 2014, Projetos paralelos - NURC-SP, v. 12.

. Tipos de frame e falantes cultos. In: PRETI, Dino (org.). Estudos de língua falada: variações e confrontos. 2.ed. São Paulo: Associação editorial humanitas, 2006. p. 71-86.

RAMOS, Jânia Martins. O espaço da oralidade na sala de aula. São Paulo: Martins Fontes, 1997.

ROJO, Roxane. O perfil do livro didático de Língua Portuguesa para o Ensino Fundamental (5 ${ }^{\mathrm{a}}$ a $8^{\mathrm{a}}$ séries). In: ROJO, Roxane Helena Rodrigues. BATISTA, Antônio Augusto Gomes. (Orgs) Livro didático de Língua Portuguesa, Letramento e cultura da escrita, pp. 69-99. Campinas, SP: Mercado de Letras, 2003.

Letramento escolar, oralidade e escrita em sala de aula: diferentes modalidades ou gêneros do discurso? In: SIGNORINI, Inês. (org.). Investigando a relação oral/escrito e as teorias do letramento. Campinas, SP: Mercado de Letras, 2001. p. 51-74.

O livro didático de Língua Portuguesa. In: O livro didático em questão. Brasília: Secretaria de Educação a Distância; Ministério da Educação, 2006. p. 4962. em<http://cdnbi.tvescola.org.br/resources/VMSResources/contents/document/publica tionsSeries/1426100829786.pdf>. Acesso em 10/01/2016.

SANTOS, Carmi Ferraz.; COSTA-MACIEL, Débora Amorim Gomes da.; BARBOSA, Maria Lúcia Ferreira de Figueiredo. Atenção, senhores ouvintes: as notícias nas ondas do rádio. In: LEAL, Telma Ferraz.; GOIS, Siane. (orgs.). A oralidade na escola: a investigação do trabalho docente como foco de reflexão. Belo Horizonte: Autêntica editora, 2012. p. 113-136. 
SERAFIM, Mônica de Souza. Da teoria à prática: um olhar sobre a oralidade na sala de aula. Revista Internacional d'Humanitats 21. CEMOrOc - Feusp/ Univ. Autônoma de Barcelona. Jan-jun 2011. p. 27-34. Disponível em <http://www.hottopos.com/rih21/P27a34.pdf>. Acesso em 15/01/2014.

SILVA, Luiz Antônio. Projeto Nurc: histórico. Revista Linha d'Água. n.10, p. 83-90, julho, $1996 . \quad$ Disponível em <http://www.revistas.fflch.usp.br/linhadagua/article/viewFile/281/288>. Acesso em 10/04/2014.

SILVA, Paulo Eduardo Mendes da.; MORI-DE-ANGELIS, Cristiane Cagnoto. Livros didáticos de língua portuguesa ( $5^{\underline{a}}$ a $8^{\text {a }}$ séries): perspectivas sobre o ensino da linguagem oral. In: ROJO, Roxane.; BATISTA, Antônio Augusto Gomes. (orgs.). Livro didático de Língua Portuguesa, letramento e cultura da escrita. Campinas, SP: Mercado de Letras, 2003. p. 185-210.

SILVA, Flávia Matias. Dos PCN LE às OCEM: o ensino de língua inglesa e as políticas linguísticas educativas brasileiras. In: Pesquisas em discurso pedagógico, Rio de Janeiro, n.1: p. 1-18, Jan./ Jul. 2015. Disponível em <https://www.maxwell.vrac.puc-rio.br/24801/24801.PDFXXvmi= >.Acesso em 21/03/2017.

SOBRAL, Adail. Ato/atividade e evento. In.: BRAIT, Beth. (org.) Bakhtin: conceitoschave. 2.ed. São Paulo: Contexto, 2005.

SOUZA, Geraldo Tadeu. Introdução à teoria do enunciado concreto do Círculo de Bakhtin / Volochinov / Medvedev. 2.ed. São Paulo: Humanitas, 2002. p. 85-136.

SOUZA e SILVA, Maria Cecília Pérez de; CRESCITELLI, Mercedes Fátima de Canha. . Fenômenos intrínsecos da oralidade: interrupção. In: JUBRAN, Clélia Cândida Abreu Spinardi\& KOCH, IngedoreGrunfeld Villaça. Gramática do português culto falado no Brasil. Vol. 1: A construção do texto falado. Campinas: Editora Unicamp, 2006. p. 71-86.

SOUZA NETO, Alaim. O que são os PCN? O que afirmam sobre a literatura? In: Debates em Educação, Maceió, vol.7, n.12: p. 112-128, Jul./Dez. 2014. Disponível em <http://www.seer.ufal.br/index.php/debateseducacao/article/viewFile/797/1076>. Acesso em 10/02/2017.

TEIXEIRA, Lúcia. Gêneros orais na escola. In: Bakhtiniana, São Paulo, 7(1): p. 240252, Jan./Jun. 2012.

VOLOCHINOV, Valentin Nikolaevich. Marxismo e filosofia da linguagem: problemas fundamentais do método sociológico na ciência da linguagem. Trad. Sheila Grillo e EkaterinaVólkova Américo. São Paulo: Editora 34, 1929/2017.

A construção da enunciação. In: A construção da enunciação e outros ensaios. São Carlos: Pedro \& João Editores, 1930/2013b. p. 157-188.

A palavra e sua função social. In: A construção da enunciação e outros ensaios. São Carlos: Pedro \& João Editores, 1930/2013c. p. 189-212. 
A palavra na vida e a palavra na poesia: introdução ao problema da poética sociológica In: A construção da enunciação e outros ensaios. São Carlos: Pedro \& João Editores, 1926/2013. p. 71-100.

Que é linguagem? In: A construção da enunciação e outros ensaios. São Carlos: Pedro \& João Editores, 1930/2013a.p. 131-156. 


\section{ANEXO 1 - Relação das obras aprovadas no PNLD 2015}

\begin{tabular}{|c|c|}
\hline 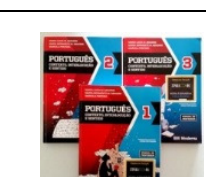 & $\begin{array}{l}\text { PORTUGUÉS CONTEXTO, INTERLOCUÇÃO E SENTIDO } \\
\text { ABAURRE, Maria Luiza M.; ABAURRE, Maria Bernadete M.; PONTARA, Marcela. } \\
\text { Português: contexto, interlocução e sentido. 2.ed. São Paulo: Moderna, } 2013 .\end{array}$ \\
\hline \multicolumn{2}{|c|}{$\begin{array}{l}\text { LÍNGUA PORTUGUESA } \\
\text { HERNANDES, Roberta.; MARTIN, Vima Lia. Língua Portuguesa. São Paulo: } \\
\text { Positivo, 2013. }\end{array}$} \\
\hline $12 \div 3=3$ & $\begin{array}{l}\text { LÍNGUA PORTUGUESA: LINGUAGEM E INTERAÇÃO } \\
\text { FARACO, Carlos Emílio. MOURA, Francisco Marto de. MARUXO JR., José } \\
\text { Hamilton. Língua Portuguesa: Linguagem e interação. 2.ed. São Paulo: Ática, } \\
2013 .\end{array}$ \\
\hline \multicolumn{2}{|c|}{$\begin{array}{l}\text { NOVAS PALAVRAS } \\
\text { AMARAL, Emília. (et. al.). Novas palavras. 2.ed. São Paulo: FTD, } 2013 .\end{array}$} \\
\hline$=$ & $\begin{array}{l}\text { PORTUGUÊS, LÍNGUA E CULTURA } \\
\text { FARACO, Carlos Alberto. Português, língua e cultura.3.ed. São Paulo: } \\
\text { editorial, } 2013 .\end{array}$ \\
\hline \multicolumn{2}{|c|}{$\begin{array}{l}\text { PORTUGUÊS LINGUAGENS } \\
\text { CEREJA, William Roberto.; MAGALHÃES, Thereza Anália Cochar. Português: } \\
\text { linguagens. 9.ed. São Paulo: Saraiva, 2013. }\end{array}$} \\
\hline 27 & $\begin{array}{l}\text { PORTUGUÊS: LINGUAGENS EM CONEXÃO } \\
\text { SETTE, Graça.; TRAVALHA, Márcia:; STARLING, Rozário. Português: } \\
\text { linguagens em conexão. São Paulo: Leya, } 2013 .\end{array}$ \\
\hline \multicolumn{2}{|c|}{$\begin{array}{l}\text { VOZES DO MUNDO: LITERATURA, LíNGUA E PRODUÇÃO DE TEXTO } \\
\text { ABREU-TARDELLI, Lília Santos. (et. al.) Vozes do mundo: literatura, língua e } \\
\text { produção de texto. São Paulo: Saraiva, 2013. }\end{array}$} \\
\hline 2 & $\begin{array}{l}\text { SER PROTAGONISTA LÍNGUA PORTUGUESA } \\
\text { (Col.9-SPLP) } \\
\text { RAMOS, Rogério de Araújo. Ser protagonista: língua portuguesa.2.ed. S } \\
\text { Edições SM, 2013. }\end{array}$ \\
\hline $\begin{array}{l}\text { VIVA PORTL } \\
\text { CAMPOS, EI } \\
\text { de. Viva Port }\end{array}$ & $\begin{array}{l}\text { Ĵ́S } \\
\text { eth Marques. CARDOSO, Paula Marques. ANDRADE, Silvia Letícia } \\
\text { ês.2.ed. São Paulo: Ática, 2013. }\end{array}$ \\
\hline
\end{tabular}




\title{
ANEXO 2 - Relação das obrasdo PNLD 2015 mais adquiridas pelo FNDE
}

\author{
FUNDO NACIONAL DE DESENVOLVIMENTO DA EDUCAÇĀO \\ Programa Nacionat do Livro Didático - PNLD
}

PNLD 2015 - Coleçōes mais distribuidas por componente curricular Portuguès

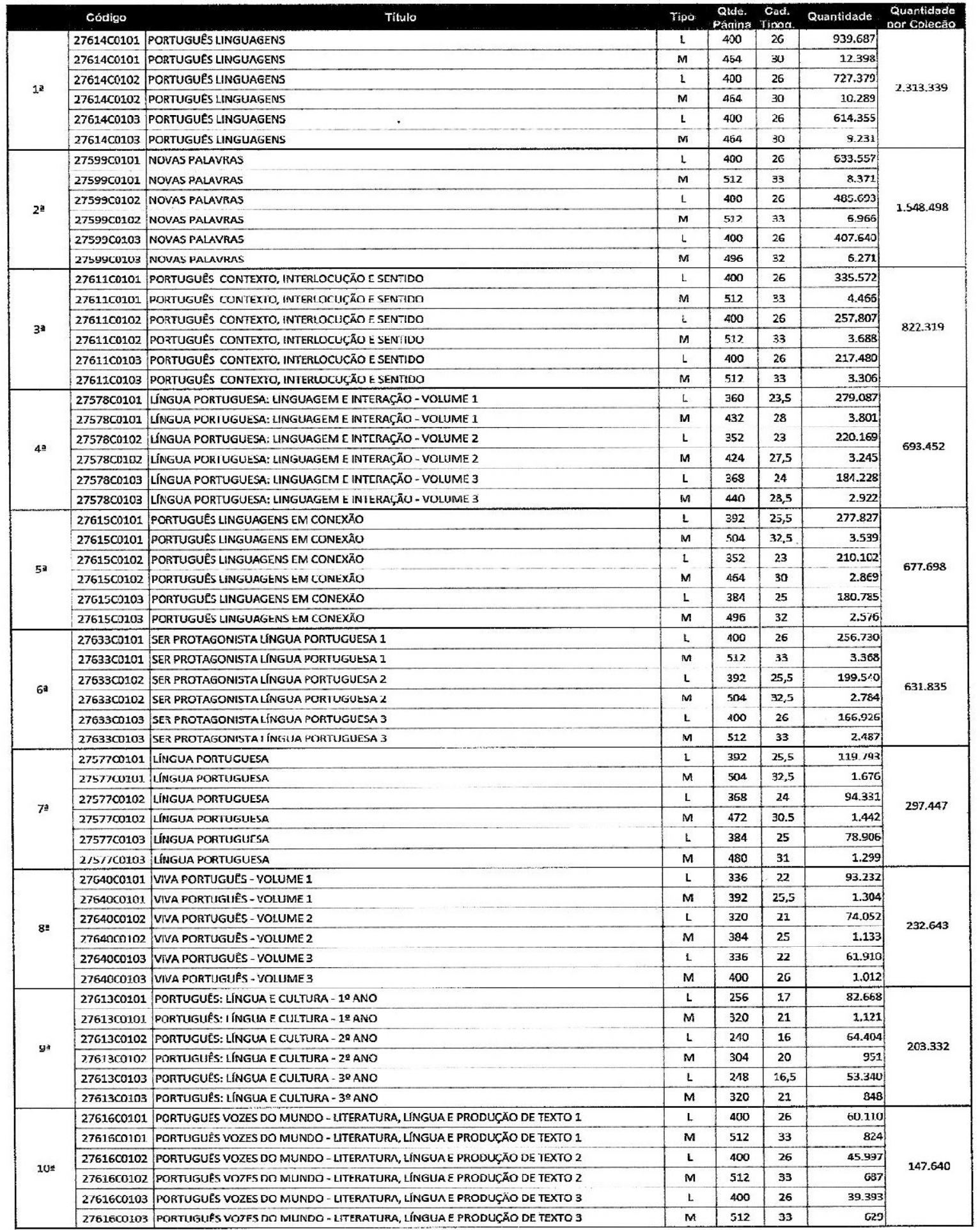

Fonte: FNDE. Arquivo PDF. Disponível em <http://www.fnde.gov.br/programas/programas-dolivro/livro-didatico/dados-estatisticos>. Acesso em 20/03/2016. 
ANEXO 3a - Gêneros orais em Português Linguagens - vol.1

\begin{tabular}{|c|c|c|c|c|c|}
\hline 을 & Capítulo & Eixo & Gênero oral & & Localização \\
\hline \multirow{12}{*}{ 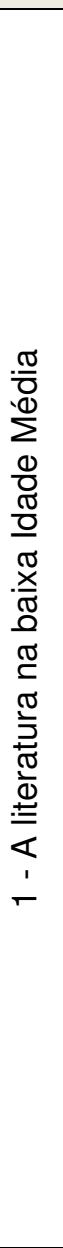 } & 0-Abertura da Unidade & Literatura & Canção & p.11 & $\begin{array}{l}\text { Seção "Fique ligado! } \\
\text { Pesquise!" }\end{array}$ \\
\hline & 1-O que é literatura & Literatura & ----- & ----- & ----- \\
\hline & $\begin{array}{l}\text { 2-Introdução aos gêneros } \\
\text { do discurso }\end{array}$ & $\begin{array}{l}\text { Produção de } \\
\text { Texto }\end{array}$ & ----- & ----- & ----- \\
\hline & $\begin{array}{l}\text { 3-Linguagem, } \\
\text { comunicação e interação }\end{array}$ & $\begin{array}{l}\text { Língua: uso e } \\
\text { reflexão }\end{array}$ & ----- & ----- & ----- \\
\hline & 4-O poema & $\begin{array}{l}\text { Produção de } \\
\text { Texto }\end{array}$ & ----- & ----- & ----- \\
\hline & $\begin{array}{l}\text { 5-A linguagem do } \\
\text { trovadorismo }\end{array}$ & Literatura & ----- & ----- & ----- \\
\hline & $6-0$ texto teatral escrito & $\begin{array}{l}\text { Produção de } \\
\text { Texto }\end{array}$ & ----- & $\begin{array}{l}---- \\
\end{array}$ & ----- \\
\hline & $\begin{array}{l}\text { 7-As variedades } \\
\text { linguísticas }\end{array}$ & $\begin{array}{l}\text { Língua: uso e } \\
\text { reflexão }\end{array}$ & $\begin{array}{l}\text { Roda de } \\
\text { discussão }\end{array}$ & p.79 & $\begin{array}{l}\text { Questão 3b Seção } \\
\text { "Construindo o } \\
\text { conceito" }\end{array}$ \\
\hline & $\begin{array}{l}\text { 8-A produção literária } \\
\text { medieval }\end{array}$ & Literatura & ----- & ----- & ----- \\
\hline & 9-Figuras de linguagem & $\begin{array}{l}\text { Língua: uso e } \\
\text { reflexão }\end{array}$ & $\begin{array}{l}---- \\
\end{array}$ & $\begin{array}{l}---- \\
\end{array}$ & ----- \\
\hline & $\begin{array}{l}\text { 10-Competência leitora e } \\
\text { habilidades de leitura }\end{array}$ & $\begin{array}{l}\text { Interpretação de } \\
\text { texto }\end{array}$ & $\begin{array}{c}---- \\
\end{array}$ & $\begin{array}{l}---- \\
\end{array}$ & $\begin{array}{c}---- \\
\end{array}$ \\
\hline & Vivências & $\begin{array}{l}\text { Literatura/ } \\
\text { Produção de } \\
\text { Texto }\end{array}$ & $\begin{array}{l}\text { Poema / } \\
\text { cordel / fábula } \\
\text { (declamar) } \\
\text { Peça teatral }\end{array}$ & p.123 & Seção "Projeto" \\
\hline \multirow{10}{*}{ 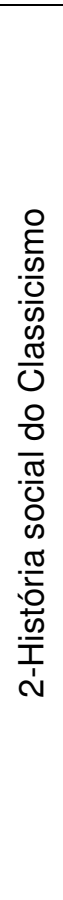 } & 0-Abertura da Unidade & Literatura & Canção & p.125 & $\begin{array}{l}\text { Seção "Fique ligado! } \\
\text { Pesquise!" }\end{array}$ \\
\hline & $\begin{array}{l}\text { 1-A linguagem do } \\
\text { Classicismo renascentista }\end{array}$ & Literatura & ----- & ----- & $\begin{array}{ll}---- \\
\end{array}$ \\
\hline & $2-\mathrm{O}$ relato pessoal & $\begin{array}{l}\text { Produção de } \\
\text { Texto }\end{array}$ & $\begin{array}{l}---- \\
\end{array}$ & $\begin{array}{l}---- \\
\end{array}$ & ----- \\
\hline & $\begin{array}{l}\text { 3-Texto e discurso - } \\
\text { Intertexto e interdiscurso }\end{array}$ & $\begin{array}{l}\text { Língua: uso e } \\
\text { reflexão }\end{array}$ & ----- & ---- & ----- \\
\hline & $\begin{array}{l}\text { 4-O Classicismo em } \\
\text { Portugal }\end{array}$ & Literatura & Canção & p.169 & $\begin{array}{l}\text { Seção "Literatura } \\
\text { Comparada" }\end{array}$ \\
\hline & $\begin{array}{l}\text { 5-Hipertexto e gêneros } \\
\text { digitais: o e-mail, o blog e } \\
\text { o comentário }\end{array}$ & $\begin{array}{l}\text { Produção de } \\
\text { Texto }\end{array}$ & ----- & ----- & ---- \\
\hline & 6-Introdução à semântica & $\begin{array}{l}\text { Língua: uso e } \\
\text { reflexão }\end{array}$ & ----- & $\begin{array}{c}---- \\
\end{array}$ & ----- \\
\hline & $\begin{array}{l}\text { 7-O Quinhentismo no } \\
\text { Brasil }\end{array}$ & Literatura & ---- & ---- & ----- \\
\hline & $\begin{array}{l}\text { 8-A observação, a análise } \\
\text { e a identificação }\end{array}$ & $\begin{array}{l}\text { Interpretação de } \\
\text { texto }\end{array}$ & ---- & --- & $\begin{array}{l}---- \\
\end{array}$ \\
\hline & Vivências & $\begin{array}{l}\text { Literatura / } \\
\text { Produção de } \\
\text { Texto }\end{array}$ & $\begin{array}{l}\text { Canção } \\
\text { Exposição oral }\end{array}$ & $\begin{array}{l}\text { p. } 213 \\
\text { e } 215\end{array}$ & Seção "Projeto" \\
\hline
\end{tabular}




\begin{tabular}{|c|c|c|c|c|c|}
\hline 음 & Capítulo & Eixo & Gênero oral & & Localização \\
\hline \multirow{12}{*}{ 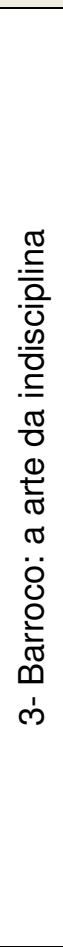 } & 0-Abertura da Unidade & Literatura & Canção & p.217 & $\begin{array}{l}\text { Seção "Fique ligado! } \\
\text { Pesquise!" }\end{array}$ \\
\hline & 1-A linguagem do Barroco & Literatura & ---- & ----- & $\begin{array}{l}---- \\
-\end{array}$ \\
\hline & $\begin{array}{l}\text { 2-Os gêneros } \\
\text { instrucionais }\end{array}$ & $\begin{array}{l}\text { Produção de } \\
\text { Texto }\end{array}$ & ----- & ----- & ----- \\
\hline & 3-Sons e letras & $\begin{array}{l}\text { Língua: uso e } \\
\text { reflexão }\end{array}$ & ----- & ----- & ----- \\
\hline & 4-O Barroco em Portugal & Literatura & ----- & ----- & ----- \\
\hline & 5-O resumo & $\begin{array}{l}\text { Produção de } \\
\text { Texto }\end{array}$ & ----- & ----- & ----- \\
\hline & $\begin{array}{l}\text { 6-A expressão escrita: } \\
\text { ortografia - divisão } \\
\text { silábica }\end{array}$ & $\begin{array}{l}\text { Língua: uso e } \\
\text { reflexão }\end{array}$ & ----- & ----- & ----- \\
\hline & 7-O Barroco no Brasil & Literatura & $\begin{array}{c}---- \\
-9\end{array}$ & ----- & ----- \\
\hline & 8-O seminário & $\begin{array}{l}\text { Produção de } \\
\text { Texto }\end{array}$ & Seminário & $\begin{array}{l}\text { p.287 } \\
\text { a } 295\end{array}$ & Capítulo 8 (íntegra) \\
\hline & $\begin{array}{l}\text { 9-A expressão escrita: } \\
\text { acentuação }\end{array}$ & $\begin{array}{l}\text { Língua: uso e } \\
\text { reflexão }\end{array}$ & ----- & ----- & ----- \\
\hline & $\begin{array}{l}\text { 10-A comparação e a } \\
\text { memorização }\end{array}$ & $\begin{array}{l}\text { Interpretação de } \\
\text { texto }\end{array}$ & ----- & ----- & ----- \\
\hline & Vivências & $\begin{array}{l}\text { Literatura / } \\
\text { Produção de } \\
\text { Texto }\end{array}$ & ---- & ----- & ----- \\
\hline \multirow{11}{*}{ 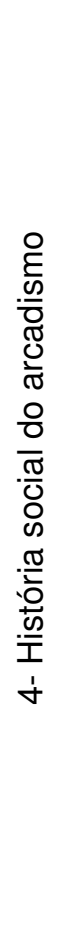 } & 0-Abertura da Unidade & Literatura & Canção & p.317 & $\begin{array}{l}\text { Seção "Fique ligado! } \\
\text { Pesquise!" }\end{array}$ \\
\hline & $\begin{array}{l}\text { 1-A linguagem do } \\
\text { Arcadismo }\end{array}$ & Literatura & $\begin{array}{l}\text { Roda de } \\
\text { conversa }\end{array}$ & p.326 & $\begin{array}{l}\text { Box "Roteiro de } \\
\text { estudo" }\end{array}$ \\
\hline & $\begin{array}{l}\text { 2-O debate regrado } \\
\text { público }\end{array}$ & $\begin{array}{l}\text { Produção de } \\
\text { Texto }\end{array}$ & $\begin{array}{l}\text { Debate } \\
\text { regrado } \\
\text { público }\end{array}$ & $\begin{array}{l}\text { p.327 } \\
\text { a } 333\end{array}$ & Capítulo 2 (íntegra) \\
\hline & 3-Estrutura de palavras & $\begin{array}{l}\text { Língua: uso e } \\
\text { reflexão }\end{array}$ & ----- & ----- & ----- \\
\hline & $\begin{array}{l}\text { 4-O Arcadismo em } \\
\text { Portugal }\end{array}$ & Literatura & ----- & $\begin{array}{l}---- \\
\end{array}$ & ----- \\
\hline & 5-O artigo de opinião & $\begin{array}{l}\text { Produção de } \\
\text { Texto }\end{array}$ & ----- & ----- & ----- \\
\hline & 6-Formação de palavras & $\begin{array}{l}\text { Língua: uso e } \\
\text { reflexão }\end{array}$ & ----- & ----- & ----- \\
\hline & 7-O Arcadismo no Brasil & Literatura & ----- & ----- & ----- \\
\hline & $\begin{array}{l}\text { 8-O texto dissertativo- } \\
\text { argumentativo }\end{array}$ & $\begin{array}{l}\text { Produção de } \\
\text { Texto }\end{array}$ & ----- & ----- & ----- \\
\hline & $\begin{array}{l}\text { 9-A explicação e a } \\
\text { demonstração }\end{array}$ & $\begin{array}{l}\text { Interpretação de } \\
\text { texto }\end{array}$ & ---- & ----- & ----- \\
\hline & Vivências & $\begin{array}{l}\text { Literatura / } \\
\text { Produção de } \\
\text { Texto }\end{array}$ & $\begin{array}{l}\text { Poema } \\
\text { (declamar) } \\
\text { Exposição oral }\end{array}$ & p.397 & Seção "Projeto" \\
\hline
\end{tabular}

(Continuação: Anexo 3a - Gêneros orais em Português Linguagens - vol.1) 
ANEXO 3b - Gêneros orais em Português Linguagens- vol.2

\begin{tabular}{|c|c|c|c|c|c|}
\hline 을 & Capítulo & Eixo & Gênero & \multicolumn{2}{|c|}{ Localização } \\
\hline \multirow{15}{*}{ 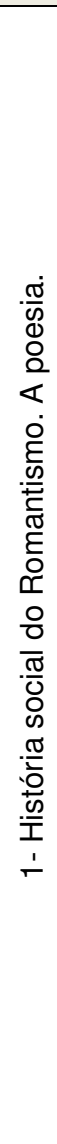 } & 0-Abertura da Unidade & Literatura & Canção & p.11 & $\begin{array}{l}\text { Seção "Fique } \\
\text { ligado! Pesquise!" }\end{array}$ \\
\hline & 1-A linguagem do romantismo & Literatura & $\begin{array}{l}\text { Roda de } \\
\text { conversa }\end{array}$ & p.21 & $\begin{array}{l}\text { Box "Roteiro de } \\
\text { estudo" }\end{array}$ \\
\hline & 2-O cartaz e o anúncio publicitário & $\begin{array}{l}\text { Produção de } \\
\text { Texto }\end{array}$ & $\begin{array}{ll}---- \\
\end{array}$ & $\begin{array}{ll}---- \\
\end{array}$ & $\begin{array}{ll}---- \\
\end{array}$ \\
\hline & 3-O substantivo & $\begin{array}{l}\text { Língua: uso e } \\
\text { reflexão }\end{array}$ & $-\cdots$ & ----- & ----- \\
\hline & 4-O Romantismo em Portugal & Literatura & $\begin{array}{ll}---- \\
\end{array}$ & $\begin{array}{ll}---- \\
\end{array}$ & $\begin{array}{ll}---- \\
\end{array}$ \\
\hline & 5- $\mathrm{O}$ adjetivo & $\begin{array}{l}\text { Língua: uso e } \\
\text { reflexão }\end{array}$ & $\begin{array}{l}\text { Roda de } \\
\text { conversa }\end{array}$ & p.51 & $\begin{array}{l}\text { Questão 3b Seção } \\
\text { "Semântica e } \\
\text { discurso" }\end{array}$ \\
\hline & $\begin{array}{l}\text { 6- O Romantismo no Brasil: primeira } \\
\text { geração }\end{array}$ & Literatura & ----- & $\begin{array}{c}---- \\
\end{array}$ & $\begin{array}{ll}---- \\
\end{array}$ \\
\hline & 7-O texto de campanha comunitária & $\begin{array}{l}\text { Produção de } \\
\text { Texto }\end{array}$ & $\begin{array}{l}\text { Roda de } \\
\text { conversa }\end{array}$ & p.58 & $\begin{array}{l}\text { Questão 3b } \\
\text { Seção"Trabalhando } \\
\text { o gênero" }\end{array}$ \\
\hline & $8-\mathrm{O}$ artigo e o numeral & $\begin{array}{l}\text { Língua: uso e } \\
\text { reflexão }\end{array}$ & ----- & $\begin{array}{c}---- \\
\end{array}$ & $\begin{array}{ll}---- \\
\end{array}$ \\
\hline & $9-\mathrm{O}$ conto & $\begin{array}{l}\text { Produção de } \\
\text { Texto }\end{array}$ & ---- & ----- & 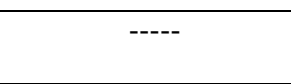 \\
\hline & 10-O Ultrarromantismo & Literatura & 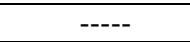 & $\begin{array}{c}---- \\
-1\end{array}$ & 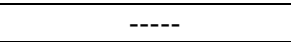 \\
\hline & 11-O pronome & $\begin{array}{l}\text { Língua: uso e } \\
\text { reflexão }\end{array}$ & $\begin{array}{ll}---- \\
\end{array}$ & $\begin{array}{c}---- \\
\end{array}$ & $\begin{array}{ll}---- \\
\end{array}$ \\
\hline & $12-\mathrm{O}$ condoreirismo & Literatura & ----- & ----- & ----- \\
\hline & 13-Justificação e conclusão & $\begin{array}{l}\text { Interpretação } \\
\text { de texto }\end{array}$ & ----- & ----- & ----- \\
\hline & Vivências & $\begin{array}{l}\text { Literatura / } \\
\text { Produção de } \\
\text { Texto }\end{array}$ & $\begin{array}{c}---- \\
-1\end{array}$ & $\begin{array}{ll}---- \\
\end{array}$ & ----- \\
\hline \multirow{13}{*}{ 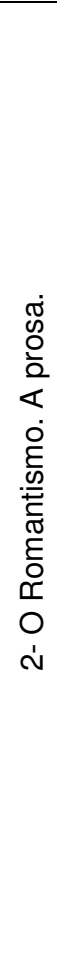 } & 0-Abertura da Unidade & Literatura & Canção & p.127 & $\begin{array}{l}\text { Seção "Fique } \\
\text { ligado! Pesquise!" }\end{array}$ \\
\hline & $\begin{array}{l}\text { 1-O romance romântico e a identidade } \\
\text { nacional. O romance indianista }\end{array}$ & Literatura & ----- & $\begin{array}{l}---- \\
\end{array}$ & $\begin{array}{ll}---- \\
\end{array}$ \\
\hline & $2-\mathrm{O}$ verbo & $\begin{array}{l}\text { Língua: uso e } \\
\text { reflexão }\end{array}$ & $\begin{array}{l}---- \\
\end{array}$ & $\begin{array}{ll}---- \\
\end{array}$ & $\begin{array}{ll}---- \\
\end{array}$ \\
\hline & 3-O romance regional & Literatura & ----- & ----- & ----- \\
\hline & 4-A mesa-redonda & $\begin{array}{l}\text { Produção de } \\
\text { Texto }\end{array}$ & $\begin{array}{l}\text { Mesa- } \\
\text { redonda }\end{array}$ & $\begin{array}{l}\text { p.155a } \\
164\end{array}$ & Capítulo 4 (íntegra) \\
\hline & 5-O advérbio & $\begin{array}{l}\text { Língua: uso e } \\
\text { reflexão }\end{array}$ & ----- & ----- & ----- \\
\hline & 6-O romance urbano & Literatura & $\begin{array}{ll}---- \\
\end{array}$ & ----- & $\begin{array}{ll}---- \\
\end{array}$ \\
\hline & $\begin{array}{l}\text { 7-Palavras relacionais: a preposição e } \\
\text { a conjunção }\end{array}$ & $\begin{array}{l}\text { Língua: uso e } \\
\text { reflexão }\end{array}$ & ----- & ----- & $\begin{array}{ll}---- \\
\end{array}$ \\
\hline & 8-A prosa gótica & Literatura & ----- & ----- & ----- \\
\hline & 9-A notícia & $\begin{array}{l}\text { Produção de } \\
\text { Texto }\end{array}$ & ----- & ----- & ----- \\
\hline & 10-A interjeição & $\begin{array}{l}\text { Língua: uso e } \\
\text { reflexão }\end{array}$ & ----- & ----- & ----- \\
\hline & $\begin{array}{l}\text { 11-Habilidades de leitura e suas } \\
\text { operações: levantamento de hipóteses } \\
\text { e relação }\end{array}$ & $\begin{array}{l}\text { Interpretação } \\
\text { de texto }\end{array}$ & ----- & ----- & ----- \\
\hline & Vivências & $\begin{array}{l}\text { Literatura / } \\
\text { Produção de } \\
\text { Texto }\end{array}$ & $\begin{array}{l}\text { Peça teatral } \\
\text { Canção } \\
\text { Poema } \\
\text { (declamar) }\end{array}$ & $\begin{array}{l}\text { p.214a } \\
217\end{array}$ & Seção "Projeto" \\
\hline
\end{tabular}




\begin{tabular}{|c|c|c|c|c|c|}
\hline 을 & Capítulo & Eixo & Gênero & \multicolumn{2}{|c|}{ Localização } \\
\hline \multirow{12}{*}{ 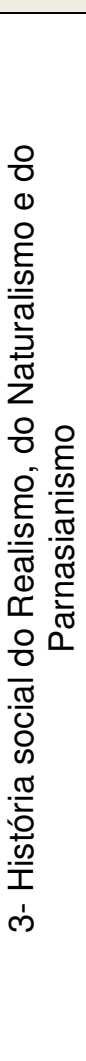 } & 0-Abertura da Unidade & Literatura & ----- & ----- & ----- \\
\hline & $\begin{array}{l}\text { 1-A linguagem do Realismo, do } \\
\text { Naturalismo e do Parnasianismo }\end{array}$ & Literatura & $\begin{array}{l}\text { Roda de } \\
\text { conversa }\end{array}$ & p.238 & $\begin{array}{l}\text { Box "Roteiro de } \\
\text { estudo" }\end{array}$ \\
\hline & 2-A entrevista & $\begin{array}{l}\text { Produção de } \\
\text { Texto }\end{array}$ & Entrevista & $\begin{array}{l}\text { p.239 } \\
\text { a } 248\end{array}$ & $\begin{array}{l}\text { Capítulo } 2 \\
\text { (íntegra) }\end{array}$ \\
\hline & $\begin{array}{l}\text { 3-O modelo morfossintátivo - } 0 \\
\text { sujeito e o predicado }\end{array}$ & $\begin{array}{l}\text { Língua: uso e } \\
\text { reflexão }\end{array}$ & ----- & ----- & ---- \\
\hline & 4-O Realismo em Portugal & Literatura & ----- & ----- & ----- \\
\hline & 5-A reportagem & $\begin{array}{l}\text { Produção de } \\
\text { Texto }\end{array}$ & ---- & ---- & ---- \\
\hline & $\begin{array}{l}\text { 6-Termos ligados ao verbo: objeto } \\
\text { direto, objeto indireto, adjunto } \\
\text { adverbial }\end{array}$ & $\begin{array}{l}\text { Língua: uso e } \\
\text { reflexão }\end{array}$ & $\begin{array}{c}---- \\
-1\end{array}$ & ---- & $\begin{array}{c}---- \\
-\cdots\end{array}$ \\
\hline & $\begin{array}{l}\text { 7-O Realismo e o Naturalismo no } \\
\text { Brasil }\end{array}$ & Literatura & ----- & ---- & ----- \\
\hline & 8-O predicado. Tipos de predicado & $\begin{array}{l}\text { Língua: uso e } \\
\text { reflexão }\end{array}$ & $\begin{array}{c}---- \\
\end{array}$ & $\begin{array}{c}---- \\
\end{array}$ & $\begin{array}{c}---- \\
\end{array}$ \\
\hline & 9-O Parnasianismo no Brasil & Literatura & ----- & ----- & ----- \\
\hline & $\begin{array}{l}\text { 10-Habilidades de leitura e suas } \\
\text { operações: a inferência e a } \\
\text { interpretação }\end{array}$ & $\begin{array}{l}\text { Interpretação } \\
\text { de texto }\end{array}$ & ---- & ---- & ---- \\
\hline & Vivências & $\begin{array}{l}\text { Literatura / } \\
\text { Produção de } \\
\text { Texto }\end{array}$ & $\begin{array}{c}---- \\
-1\end{array}$ & $\begin{array}{c}---- \\
\end{array}$ & $\begin{array}{c}---- \\
\end{array}$ \\
\hline \multirow{13}{*}{ 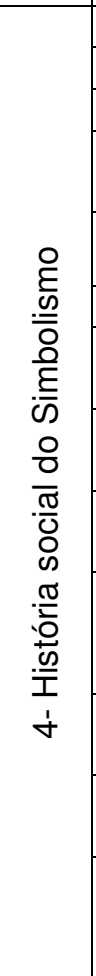 } & 0-Abertura da Unidade & Literatura & ----- & ----- & ----- \\
\hline & 1-A linguagem do Simbolismo & Literatura & ----- & ----- & ----- \\
\hline & 2-O Simbolismo em Portugal & Literatura & ----- & ----- & ----- \\
\hline & 3-A crítica & $\begin{array}{l}\text { Produção de } \\
\text { Texto }\end{array}$ & ----- & ----- & ----- \\
\hline & 4-Tipos de sujeito & $\begin{array}{l}\text { Língua: uso e } \\
\text { reflexão }\end{array}$ & $\begin{array}{c}---- \\
-1\end{array}$ & $\begin{array}{c}---- \\
\end{array}$ & $\begin{array}{ll}---- \\
\end{array}$ \\
\hline & 5-O Simbolismo no Brasil & Literatura & ----- & ----- & ----- \\
\hline & 6-O editorial & $\begin{array}{l}\text { Produção de } \\
\text { Texto }\end{array}$ & $\begin{array}{c}---- \\
-1\end{array}$ & $\begin{array}{c}---- \\
-1\end{array}$ & $\begin{array}{c}---- \\
-1\end{array}$ \\
\hline & $\begin{array}{l}\text { 7-Termos ligados ao nome: adjunto } \\
\text { adnominal e complemento nominal }\end{array}$ & $\begin{array}{l}\text { Língua: uso e } \\
\text { reflexão }\end{array}$ & ----- & $\begin{array}{c}---- \\
-1\end{array}$ & $\begin{array}{c}---- \\
-1\end{array}$ \\
\hline & 8-O teatro brasileiro no século XIX & Literatura & ----- & ----- & ----- \\
\hline & $\begin{array}{l}\text { 9-O texto dissertativo- } \\
\text { argumentativo: redação a partir de } \\
\text { um painel de textos }\end{array}$ & $\begin{array}{l}\text { Produção de } \\
\text { Texto }\end{array}$ & $\begin{array}{c}---- \\
-1\end{array}$ & ---- & $\begin{array}{c}---- \\
\end{array}$ \\
\hline & $\begin{array}{l}\text { 10-Termos ligados ao nome: } \\
\text { aposto e vocativo }\end{array}$ & $\begin{array}{l}\text { Língua: uso e } \\
\text { reflexão }\end{array}$ & $\begin{array}{c}---- \\
\end{array}$ & $\begin{array}{c}---- \\
\end{array}$ & $\begin{array}{c}---- \\
-1\end{array}$ \\
\hline & $\begin{array}{l}\text { 11-As situações-problema nas } \\
\text { provas do Enem e dos vestibulares }\end{array}$ & $\begin{array}{l}\text { Interpretação } \\
\text { de texto }\end{array}$ & $\begin{array}{c}---- \\
\end{array}$ & $\begin{array}{c}---- \\
\end{array}$ & $\begin{array}{c}---- \\
\end{array}$ \\
\hline & Vivências & $\begin{array}{l}\text { Literatura } \\
\text { /Produção de } \\
\text { Texto }\end{array}$ & $\begin{array}{l}\text { Poema } \\
\text { (declamar) }\end{array}$ & p.396 & Seção "Projeto" \\
\hline
\end{tabular}

(Continuação: Anexo 3b - Gêneros orais em Português Linguagens - vol.2) 
ANEXO 3c - Gêneros orais em Português Linguagens - vol.3

\begin{tabular}{|c|c|c|c|c|c|}
\hline 을 & Capítulo & Eixo & Gênero & \multicolumn{2}{|c|}{ Localização } \\
\hline \multirow{13}{*}{ 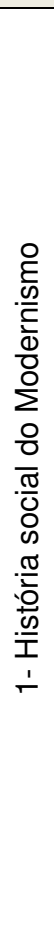 } & 0-Abertura da Unidade & Literatura & Canção & p.11 & $\begin{array}{l}\text { Seção "Fique } \\
\text { ligado! Pesquise!" }\end{array}$ \\
\hline & 1-O Pré-Modernismo & Literatura & ----- & $\begin{array}{ll}---- \\
\end{array}$ & $\begin{array}{cc}---- \\
---1\end{array}$ \\
\hline & 2-A linguagem do Modernismo & Literatura & $\begin{array}{l}\text { Roda de } \\
\text { conversa }\end{array}$ & p.36 & $\begin{array}{l}\text { Box "Roteiro de } \\
\text { estudo" }\end{array}$ \\
\hline & 3-A crônica & $\begin{array}{l}\text { Produção de } \\
\text { Texto }\end{array}$ & ----- & ----- & ----- \\
\hline & 4-Vanguardas em ação & Literatura & ----- & ----- & ----- \\
\hline & $\begin{array}{l}\text { 5-Período composto por subordinação: } \\
\text { as orações substantivas }\end{array}$ & $\begin{array}{l}\text { Língua: uso e } \\
\text { reflexão }\end{array}$ & ----- & ----- & ----- \\
\hline & $\begin{array}{l}\text { 6-O Modernismo em Portugal: a } \\
\text { primeira geração }\end{array}$ & Literatura & $\begin{array}{ll}---- \\
\end{array}$ & $\begin{array}{ll}---- \\
\end{array}$ & $\begin{array}{ll}---- \\
\end{array}$ \\
\hline & $\begin{array}{l}\text { 7- Período composto por subordinação: } \\
\text { as orações adjetivas }\end{array}$ & $\begin{array}{l}\text { Língua: uso e } \\
\text { reflexão }\end{array}$ & ---- & ----- & ----- \\
\hline & $\begin{array}{l}\text { 8-A primeira fase do Modernismo: Os } \\
\text { Andrades }\end{array}$ & Literatura & ----- & ----- & ----- \\
\hline & 9- O texto de divulgação científica & $\begin{array}{l}\text { Produção de } \\
\text { Texto }\end{array}$ & ----- & $\begin{array}{ll}---- \\
\end{array}$ & $\begin{array}{ll}---- \\
\end{array}$ \\
\hline & $\begin{array}{l}\text { 10-Manuel Bandeira e Alcântara } \\
\text { Machado }\end{array}$ & Literatura & ----- & ----- & ----- \\
\hline & 11-O Enem e os cinco eixos cognitivos & $\begin{array}{l}\text { Interpretação } \\
\text { de texto }\end{array}$ & ---- & ----- & ----- \\
\hline & Vivências & $\begin{array}{l}\text { Literatura / } \\
\text { Produção de } \\
\text { Texto }\end{array}$ & ----- & ----- & ----- \\
\hline \multirow{12}{*}{ 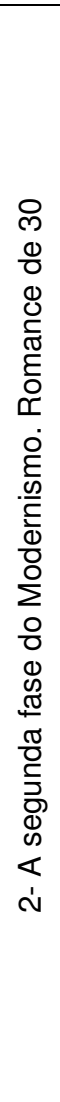 } & 0-Abertura da Unidade. & Literatura & Canção & p.133 & $\begin{array}{l}\text { Seção "Fique } \\
\text { ligado! Pesquise!" }\end{array}$ \\
\hline & $\begin{array}{l}\text { 1- O romance de } 30 . \text { Rachel de } \\
\text { Queiroz }\end{array}$ & Literatura & $\begin{array}{l}\text { Roda de } \\
\text { conversa }\end{array}$ & p.138 & $\begin{array}{l}\text { Box "Roteiro de } \\
\text { estudo" }\end{array}$ \\
\hline & 2-A carta de leitor & $\begin{array}{l}\text { Produção de } \\
\text { Texto }\end{array}$ & ---- & ---- & ---- \\
\hline & $\begin{array}{l}\text { 3- Período composto por subordinação: } \\
\text { as orações adverbiais }\end{array}$ & $\begin{array}{l}\text { Língua: uso e } \\
\text { reflexão }\end{array}$ & ----- & $\begin{array}{c}---- \\
\end{array}$ & ----- \\
\hline & $\begin{array}{l}\text { 4-O Nordeste no romance de } 30 . \\
\text { Graciliano Ramos, José Lins do Rego e } \\
\text { Jorge Amado }\end{array}$ & Literatura & ----- & ----- & ----- \\
\hline & $\begin{array}{l}\text { 5-As cartas argumentativas de } \\
\text { reclamação e de solicitação }\end{array}$ & $\begin{array}{l}\text { Produção de } \\
\text { Texto }\end{array}$ & ----- & ----- & ----- \\
\hline & $\begin{array}{l}\text { 6- Período composto por coordenação: } \\
\text { as orações coordenadas }\end{array}$ & $\begin{array}{l}\text { Língua: uso e } \\
\text { reflexão }\end{array}$ & ---- & ----- & $-\cdots$ \\
\hline & $\begin{array}{l}\text { 7-O Sul no romance de } 30 \text {. Érico } \\
\text { Veríssimo e Dionélio Machado }\end{array}$ & Literatura & ----- & ----- & ----- \\
\hline & 8-A pontuação & $\begin{array}{l}\text { Língua: uso e } \\
\text { reflexão }\end{array}$ & ---- & ----- & ---- \\
\hline & $\begin{array}{l}\text { 9-O Modernismo em Portugal: a } \\
\text { segunda geração }\end{array}$ & Literatura & ----- & ----- & ----- \\
\hline & $\begin{array}{l}\text { 10-Competências e habilidades do } \\
\text { Enem (I) }\end{array}$ & $\begin{array}{l}\text { Interpretação } \\
\text { de texto }\end{array}$ & ----- & ----- & ----- \\
\hline & Vivências & $\begin{array}{l}\text { Literatura / } \\
\text { Produção de } \\
\text { Texto }\end{array}$ & $\begin{array}{l}\text { Debate } \\
\text { Esquete } \\
\text { teatral } \\
\text { Manifesto } \\
\text { futurista } \\
\text { (declamar - } \\
\text { jogral) }\end{array}$ & $\begin{array}{l}\text { p.223a } \\
225\end{array}$ & Seção "Projeto" \\
\hline
\end{tabular}




\begin{tabular}{|c|c|c|c|c|c|}
\hline 을 & Capítulo & Eixo & Gênero & \multicolumn{2}{|c|}{ Localização } \\
\hline \multirow{10}{*}{ 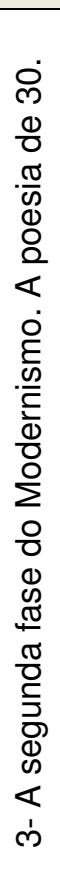 } & 0-Abertura da Unidade & Literatura & Canção & p.227 & $\begin{array}{l}\text { Seção "Fique } \\
\text { ligado! Pesquise!" }\end{array}$ \\
\hline & $\begin{array}{l}\text { 1-A poesia de } 30 . \text { Carlos } \\
\text { Drummond de Andrade }\end{array}$ & Literatura & $\begin{array}{c}---- \\
\end{array}$ & $\begin{array}{l}---- \\
\end{array}$ & $\begin{array}{c}---- \\
\end{array}$ \\
\hline & $\begin{array}{l}\text { 2-Concordância. Concordância } \\
\text { verbal }\end{array}$ & $\begin{array}{l}\text { Língua: uso e } \\
\text { reflexão }\end{array}$ & ----- & ----- & ----- \\
\hline & $\begin{array}{l}\text { 3-O debate regrado público: } \\
\text { estratégias de contra- } \\
\text { argumentação }\end{array}$ & $\begin{array}{l}\text { Produção de } \\
\text { Texto }\end{array}$ & $\begin{array}{l}\text { Debate } \\
\text { regrado } \\
\text { público }\end{array}$ & $\begin{array}{l}\text { p.251 } \\
\text { a } 258\end{array}$ & $\begin{array}{l}\text { Capítulo } 3 \\
\text { (parcial) }\end{array}$ \\
\hline & 4-Concordância nominal & $\begin{array}{l}\text { Língua: uso e } \\
\text { reflexão }\end{array}$ & ---- & $\begin{array}{l}---- \\
\end{array}$ & ----- \\
\hline & $\begin{array}{l}\text { 5-Cecília Meireles e Vinícius de } \\
\text { Morais }\end{array}$ & Literatura & ----- & $\begin{array}{ll}---- \\
\end{array}$ & ----- \\
\hline & $\begin{array}{l}\text { 6-O teatro brasileiro nos séculos } \\
X X-X X I\end{array}$ & Literatura & ----- & $\begin{array}{l}---- \\
\end{array}$ & ----- \\
\hline & $\begin{array}{l}\text { 7-Do Neorrealismo ao } \\
\text { Existencialismo em Portugal }\end{array}$ & Literatura & ----- & ----- & ----- \\
\hline & $\begin{array}{l}\text { 8-Competências e habilidades do } \\
\text { Enem (II) }\end{array}$ & $\begin{array}{l}\text { Interpretação } \\
\text { de texto }\end{array}$ & $\begin{array}{c}---- \\
\end{array}$ & $\begin{array}{ll}---- \\
\end{array}$ & ----- \\
\hline & Vivências & $\begin{array}{l}\text { Literatura } \\
\text { /Produção de } \\
\text { Texto }\end{array}$ & $\begin{array}{l}\text { Debate } \\
\text { regrado } \\
\text { público }\end{array}$ & p.295 & Seção "Projeto" \\
\hline \multirow{12}{*}{ 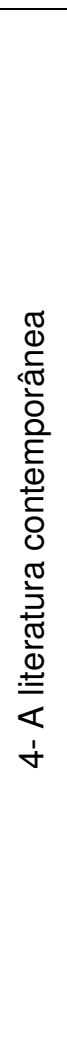 } & 0-Abertura da Unidade & Literatura & Canção & p.297 & $\begin{array}{l}\text { Seção "Fique } \\
\text { ligado! Pesquise!" }\end{array}$ \\
\hline & $\begin{array}{l}\text { 1-Os anos 1940-50. Clarice } \\
\text { Lispector }\end{array}$ & Literatura & ----- & $\begin{array}{c}---- \\
\end{array}$ & ----- \\
\hline & 2-O textodissertativo-argumentativo & $\begin{array}{l}\text { Produção de } \\
\text { Texto }\end{array}$ & ----- & ----- & ----- \\
\hline & $\begin{array}{l}\text { 3-Regência verbal e regência } \\
\text { nominal }\end{array}$ & $\begin{array}{l}\text { Língua: uso e } \\
\text { reflexão }\end{array}$ & $\begin{array}{c}---- \\
\end{array}$ & ----- & ----- \\
\hline & $\begin{array}{l}\text { 4-Guimarães Rosa: a linguagem } \\
\text { reinventada }\end{array}$ & Literatura & ----- & $\begin{array}{l}---- \\
\end{array}$ & $\begin{array}{c}---- \\
\end{array}$ \\
\hline & $\begin{array}{l}\text { 5-João Cabral de Melo Neto: a } \\
\text { linguagem objeto }\end{array}$ & Literatura & ----- & $\begin{array}{l}---- \\
\end{array}$ & ----- \\
\hline & $\begin{array}{l}\text { 6-A colocação. Colocação } \\
\text { pronominal }\end{array}$ & $\begin{array}{l}\text { Língua: uso e } \\
\text { reflexão }\end{array}$ & ----- & ---- & ----- \\
\hline & $\begin{array}{l}\text { 7-A } \\
\text { literaturaportuguesacontemporânea }\end{array}$ & Literatura & $\begin{array}{l}---- \\
\end{array}$ & $\begin{array}{l}---- \\
\end{array}$ & ----- \\
\hline & $\begin{array}{l}\text { 8-Tendências da literatura } \\
\text { brasileira contemporânea }\end{array}$ & Literatura & ----- & ----- & ----- \\
\hline & $\begin{array}{l}\text { 9-Panorama das literaturas } \\
\text { africanas de língua portuguesa }\end{array}$ & Literatura & ----- & ----- & ----- \\
\hline & $\begin{array}{l}\text { 10-Competências e habilidades do } \\
\text { Enem (III) }\end{array}$ & $\begin{array}{l}\text { Interpretação } \\
\text { de texto }\end{array}$ & ---- & ----- & ---- \\
\hline & Vivências & $\begin{array}{l}\text { Literatura } \\
\text { /Produção de } \\
\text { Texto }\end{array}$ & $\begin{array}{l}\text { Canção } \\
\text { Poema } \\
\text { (declamar - } \\
\text { jogral) }\end{array}$ & $\begin{array}{l}\text { p.394 } \\
\text { a } 397\end{array}$ & Seção "Projeto" \\
\hline
\end{tabular}

(Continuação: Anexo 3c - Gêneros orais em Português Linguagens - vol.3) 
ANEXO 4a - Gêneros orais em Novas Palavras - vol.1

\begin{tabular}{|c|c|c|c|c|}
\hline$\stackrel{x}{x}$ & Capítulo & Gênero oral & & Localização \\
\hline \multirow{17}{*}{ 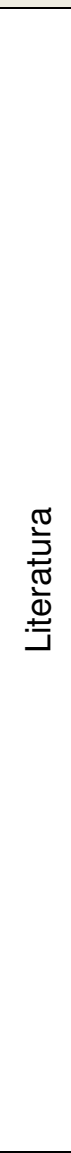 } & \multirow[t]{2}{*}{ 1-Literatura: a arte da palavra } & Roda de conversa & p.11 & $\begin{array}{l}\text { Seção "Em tom de } \\
\text { conversa" }\end{array}$ \\
\hline & & Apresentação oral & p.13 & Seção “E mais...” \\
\hline & \multirow[t]{3}{*}{ 2-O texto literário } & Roda de conversa & p.25 & $\begin{array}{l}\text { Seção "Em tom de } \\
\text { conversa" }\end{array}$ \\
\hline & & Debate & p.31 & Seção "E mais..." \\
\hline & & Roda de discussão & p.36 & Seção "E mais..." \\
\hline & \multirow[t]{2}{*}{ 3-O Trovadorismo } & Roda de conversa & $\begin{array}{l}\text { p. } 41 \text { e } \\
42\end{array}$ & $\begin{array}{l}\text { Seção "Em tom de } \\
\text { conversa" }\end{array}$ \\
\hline & & Apresentação oral & $\begin{array}{l}\text { p.51- } \\
52\end{array}$ & Seção “E mais...” \\
\hline & \multirow[t]{2}{*}{ 4-O Humanismo } & Roda de conversa & p.56 & $\begin{array}{l}\text { Seção "Em tom de } \\
\text { conversa" }\end{array}$ \\
\hline & & Peça teatral & p.67 & Seção "E mais..." \\
\hline & 5-O Renascimento & Roda de conversa & p.75 & $\begin{array}{l}\text { Seção "Em tom de } \\
\text { conversa" }\end{array}$ \\
\hline & 6-O Quinhentismo brasileiro & Roda de conversa & $\begin{array}{l}\text { p.97 e } \\
98\end{array}$ & $\begin{array}{l}\text { Seção "Em tom de } \\
\text { conversa" }\end{array}$ \\
\hline & 7-O Barroco português & Roda de conversa & p.107 & $\begin{array}{l}\text { Seção "Em tom de } \\
\text { conversa" }\end{array}$ \\
\hline & & Debate & p.108 & Seção “E mais...” \\
\hline & 8- O Barroco brasileiro & Roda de conversa & p.123 & $\begin{array}{l}\text { Seção "Em tom de } \\
\text { conversa" }\end{array}$ \\
\hline & 9- O Neoclassicismo português & Apresentação oral & p.141 & Seção “E mais...” \\
\hline & 10- O Neoclassicismo brasileiro & Roda de conversa & p.146 & $\begin{array}{l}\text { Seção "Em tom de } \\
\text { conversa" }\end{array}$ \\
\hline & & Apresentação oral & p.149 & Seção "E mais..." \\
\hline \multirow{8}{*}{ 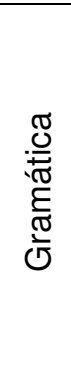 } & 1-Gramática, gramáticas... & Apresentação oral & p.184 & Seção "E mais..." \\
\hline & 2-Noções de variações linguísticas & Apresentação oral & p.198 & Seção "E mais..." \\
\hline & 3-Figuras de linguagem & Apresentação oral & p.224 & Seção "E mais..." \\
\hline & 4-Noções de semântica & ----- & $\begin{array}{l}---- \\
--1\end{array}$ & ----- \\
\hline & 5-Acentuação gráfica & ----- & ----- & $\begin{array}{c}---- \\
-1\end{array}$ \\
\hline & 6-Estrutura e formação de palavras & Apresentação oral & p.276 & Seção "E mais..." \\
\hline & 7-Substantivo / Adjetivo & ----- & $\begin{array}{c}---- \\
-1\end{array}$ & ----- \\
\hline & 8-Artigo / Numeral & ----- & ----- & ----- \\
\hline
\end{tabular}




\begin{tabular}{|c|c|c|c|c|}
\hline$\underline{\text { Px }}$ & Capítulo & Gênero oral & \multicolumn{2}{|r|}{ Localização } \\
\hline \multirow{18}{*}{ 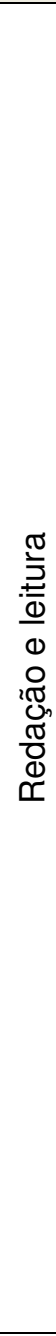 } & \multirow[t]{2}{*}{$\begin{array}{l}\text { 1-Liberação da linguagem e do } \\
\text { pensamento }\end{array}$} & Roda de conversa & p.318 & $\begin{array}{l}\text { Seção "Em tom de } \\
\text { conversa" }\end{array}$ \\
\hline & & Roda de discussão & p.322 & Seção "E mais..." \\
\hline & $\begin{array}{l}\text { 2-Linguagens: entre textos, entre } \\
\text { linhas }\end{array}$ & Debate & p.326 & Seção "E mais..." \\
\hline & 3-Experiências de enumeração & ----- & ---- & ---- \\
\hline & $\begin{array}{l}\text { 4-As modalidades clássicas: } \\
\text { descrever, narrar, dissertar }\end{array}$ & Roda de conversa & p.340 & $\begin{array}{l}\text { Seção "Em tom de } \\
\text { conversa" }\end{array}$ \\
\hline & & Apresentação oral & p.343 & Seção "E mais..." \\
\hline & $\begin{array}{l}\text { 5-Leitura: interpretação e análise de } \\
\text { texto }\end{array}$ & Roda de discussão & p.351 & Seção "E mais..." \\
\hline & 6-O que é descrever? & Roda de conversa & p.357 & $\begin{array}{l}\text { Seção "Em tom de } \\
\text { conversa" }\end{array}$ \\
\hline & & Roda de conversa & $\begin{array}{l}\text { p.359- } \\
360\end{array}$ & $\begin{array}{l}\text { Seção "Em tom de } \\
\text { conversa" }\end{array}$ \\
\hline & $\begin{array}{l}\text { 7-Descrição: subjetiva e objetiva; } \\
\text { estática e dinâmica }\end{array}$ & Roda de conversa & p.364 & $\begin{array}{l}\text { Seção "Em tom de } \\
\text { conversa" }\end{array}$ \\
\hline & & Roda de conversa & p.366 & $\begin{array}{l}\text { Seção "Em tom de } \\
\text { conversa" }\end{array}$ \\
\hline & & Entrevista & p.366 & Seção "E mais..." \\
\hline & & Roda de conversa & p.367 & $\begin{array}{l}\text { Seção "Em tom de } \\
\text { conversa" }\end{array}$ \\
\hline & 8- O que é narrar? & Roda de conversa & p.372 & $\begin{array}{l}\text { Seção "Em tom de } \\
\text { conversa" }\end{array}$ \\
\hline & 9-O mundo narrado & Roda de conversa & p.379 & $\begin{array}{l}\text { Seção "Em tom de } \\
\text { conversa" }\end{array}$ \\
\hline & & Roda de conversa & p.381 & $\begin{array}{l}\text { Seção "Em tom de } \\
\text { conversa" }\end{array}$ \\
\hline & & $\begin{array}{l}\text { Piada } \\
\text { Roda de discussão }\end{array}$ & p.382 & Seção “E mais..." \\
\hline & 10-O que é dissertar? & Roda de conversa & $\begin{array}{l}\text { p.386- } \\
387\end{array}$ & $\begin{array}{l}\text { Seção "Em tom de } \\
\text { conversa" }\end{array}$ \\
\hline
\end{tabular}

(Continuação: Anexo 4a - Gêneros orais em Novas palavras- vol.1) 
ANEXO 4b - Gêneros orais em Novas Palavras- vol.2

\begin{tabular}{|c|c|c|c|c|}
\hline 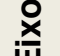 & Capítulo & Gênero oral & & Localização \\
\hline \multirow{18}{*}{ 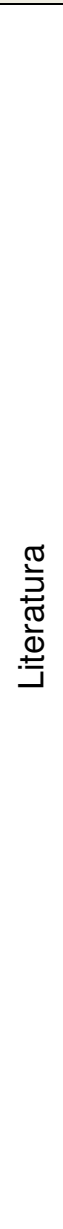 } & \multirow[t]{3}{*}{ 1-O Romantismo em Portugal } & Roda de conversa & p.10 & $\begin{array}{l}\text { Seção "Em tom de } \\
\text { conversa" }\end{array}$ \\
\hline & & Apresentação oral & p.11 & Seção "E mais" \\
\hline & & Roda de conversa & p.25 & $\begin{array}{l}\text { Seção "Em tom de } \\
\text { conversa" }\end{array}$ \\
\hline & \multirow[t]{2}{*}{ 2-O Romantismo no Brasil } & Roda de conversa & p.36 & $\begin{array}{l}\text { Seção "Em tom de } \\
\text { conversa" }\end{array}$ \\
\hline & & Roda de conversa & p.45 & $\begin{array}{l}\text { Seção "Em tom de } \\
\text { conversa" }\end{array}$ \\
\hline & \multirow[t]{4}{*}{ 3-A prosa romântica brasileira } & Roda de conversa & p.64 & $\begin{array}{l}\text { Seção "Em tom de } \\
\text { conversa" }\end{array}$ \\
\hline & & Roda de conversa & p.69 & $\begin{array}{l}\text { Seção "Em tom de } \\
\text { conversa" }\end{array}$ \\
\hline & & Roda de conversa & p.75 & $\begin{array}{l}\text { Seção "Em tom de } \\
\text { conversa" }\end{array}$ \\
\hline & & Peça teatral & $\begin{array}{l}\text { p.75- } \\
76\end{array}$ & Seção “E mais" \\
\hline & \multirow[t]{2}{*}{$\begin{array}{l}\text { 4-O Realismo e o Naturalismo em } \\
\text { Portugal }\end{array}$} & Roda de conversa & p.80 & $\begin{array}{l}\text { Seção "Em tom de } \\
\text { conversa" }\end{array}$ \\
\hline & & Roda de discussão & p.86 & Seção "E mais" \\
\hline & \multirow[t]{2}{*}{$\begin{array}{l}\text { 5-O Realismo e o Naturalismo no } \\
\text { Brasil }\end{array}$} & Roda de conversa & p.98 & $\begin{array}{l}\text { Seção "Em tom de } \\
\text { conversa" }\end{array}$ \\
\hline & & Roda de discussão & p.107 & Seção "E mais" \\
\hline & \multirow[t]{2}{*}{$\begin{array}{l}\text { 6-O Realismo psicológico de Machado } \\
\text { de Assis }\end{array}$} & Roda de conversa & $\begin{array}{l}\text { p.124- } \\
125\end{array}$ & $\begin{array}{l}\text { Seção "Em tom de } \\
\text { conversa" }\end{array}$ \\
\hline & & Documentário & p.127 & Seção "E mais" \\
\hline & 7-O Parnasianismo no Brasil & Roda de discussão & p.143 & Seção "E mais" \\
\hline & 8-O Simbolismo em Portugal & Debate & p.157 & Seção "E mais" \\
\hline & 9-O Simbolismo no Brasil & Roda de conversa & p.164 & Seção "E mais" \\
\hline \multirow{8}{*}{ 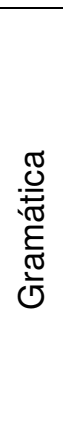 } & 1-Pronome (1 $\stackrel{a}{a}$ parte $)$ & Roda de discussão & p.190 & Seção "E mais" \\
\hline & 2-Pronome (2 ${ }^{\mathrm{a}}$ parte) & Roda de discussão & p.204 & Seção "E mais" \\
\hline & 3-Verbo (1 $\stackrel{\text { a }}{\text { parte }})$ & ----- & ----- & ----- \\
\hline & 4-Verbo (2 ${ }^{\mathrm{a}}$ parte $)$ & Roda de discussão & p.239 & Seção "E mais" \\
\hline & 5-Palavras invariáveis & ----- & $\begin{array}{c}---- \\
\end{array}$ & ----- \\
\hline & 6-A sintaxe / Sujeito e predicado & Roda de discussão & p.274 & Seção "E mais" \\
\hline & $\begin{array}{l}\text { 7-Os verbos no predicado / Termos } \\
\text { associados ao verbo }\end{array}$ & $\begin{array}{c}---- \\
\end{array}$ & 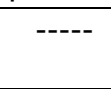 & $\begin{array}{c}---- \\
\end{array}$ \\
\hline & $\begin{array}{l}\text { 8-Termos associados a nomes / } \\
\text { Vocativo }\end{array}$ & ----- & $\begin{array}{l}---- \\
\end{array}$ & ----- \\
\hline
\end{tabular}




\begin{tabular}{|c|c|c|c|c|}
\hline$\stackrel{\circ}{x}$ & Capítulo & Gênero oral & & Localização \\
\hline \multirow{16}{*}{ 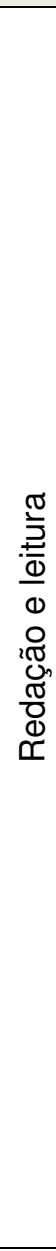 } & $\begin{array}{l}\text { 1-Linguagens: entre textos, entre } \\
\text { linhas }\end{array}$ & Recado telefônico & p.317 & $\begin{array}{l}\text { Seção "Atividades" - } \\
\text { ex. } 1\end{array}$ \\
\hline & \multirow[t]{2}{*}{ 2-O diário pessoal } & Roda de conversa & p.324 & $\begin{array}{l}\text { Seção "Em tom de } \\
\text { conversa" }\end{array}$ \\
\hline & & Debate & $\begin{array}{l}\text { p.324- } \\
325\end{array}$ & Seção "E mais" \\
\hline & \multirow[t]{3}{*}{ 3-O relatório } & Roda de conversa & p.332 & $\begin{array}{l}\text { Seção "Em tom de } \\
\text { conversa" }\end{array}$ \\
\hline & & Roda de conversa & p.334 & $\begin{array}{l}\text { Seção "Em tom de } \\
\text { conversa" }\end{array}$ \\
\hline & & Apresentação oral & p.335 & Seção "E mais" \\
\hline & \multirow[t]{2}{*}{ 4-A resenha } & Roda de conversa & p.343 & $\begin{array}{l}\text { Seção "Em tom de } \\
\text { conversa" }\end{array}$ \\
\hline & & Roda de conversa & p.348 & $\begin{array}{l}\text { Seção "Em tom de } \\
\text { conversa" }\end{array}$ \\
\hline & $\begin{array}{l}\text { 5-Do relato à narrativa ficcional: } \\
\text { modos de apresentação de } \\
\text { personagens }\end{array}$ & Roda de conversa & p.351 & $\begin{array}{l}\text { Seção "Em tom de } \\
\text { conversa" }\end{array}$ \\
\hline & \multirow[t]{3}{*}{ 6-Enredo linear e enredo não linear } & Roda de conversa & p.364 & $\begin{array}{l}\text { Seção "Em tom de } \\
\text { conversa" }\end{array}$ \\
\hline & & Roda de conversa & p.368 & $\begin{array}{l}\text { Seção "Em tom de } \\
\text { conversa" }\end{array}$ \\
\hline & & Apresentação oral & p.371 & Seção "E mais" \\
\hline & \multirow[t]{2}{*}{ 7-Narrador: a voz que conta a história } & Roda de conversa & p.374 & $\begin{array}{l}\text { Seção "Em tom de } \\
\text { conversa" }\end{array}$ \\
\hline & & $\begin{array}{l}\text { Apresentação oral } \\
\text { Encenação }\end{array}$ & p.381 & Seção "E mais" \\
\hline & \multirow[t]{2}{*}{ 8-A dissertação } & Roda de conversa & p.386 & $\begin{array}{l}\text { Seção "Em tom de } \\
\text { conversa" }\end{array}$ \\
\hline & & Debate & p.389 & Seção "E mais" \\
\hline
\end{tabular}

(Continuação: Anexo 4b - Gêneros orais em Novas palavras- vol.2) 
ANEXO 4c - Gêneros orais em Novas Palavras- vol.3

\begin{tabular}{|c|c|c|c|c|}
\hline$\stackrel{x}{x}$ & Capítulo & Gênero oral & & Localização \\
\hline \multirow{18}{*}{ 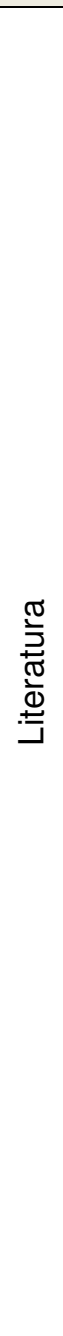 } & 1-O Pré-Modernismo no Brasil & Debate & p.21 & Seção "E mais" \\
\hline & \multirow[t]{2}{*}{$\begin{array}{l}\text { 2-As vanguardas artísticas europeias e } \\
\text { o Modernismo no Brasil }\end{array}$} & Roda de conversa & $\begin{array}{l}\text { p.36- } \\
37\end{array}$ & $\begin{array}{l}\text { Seção "Em tom de } \\
\text { conversa" }\end{array}$ \\
\hline & & Debate & p.38 & Seção "E mais" \\
\hline & \multirow[t]{3}{*}{ 3-Semana de Arte Moderna } & Roda de conversa & $\begin{array}{l}\text { p.43- } \\
44\end{array}$ & $\begin{array}{l}\text { Seção "Em tom de } \\
\text { conversa" }\end{array}$ \\
\hline & & Debate & p.50 & Seção "E mais" \\
\hline & & Roda de conversa & $\begin{array}{l}\text { p.50- } \\
51\end{array}$ & $\begin{array}{l}\text { Seção "Em tom de } \\
\text { conversa" }\end{array}$ \\
\hline & \multirow[t]{3}{*}{$\begin{array}{l}\text { 4-A primeira geração modernista } \\
\text { brasileira }\end{array}$} & Roda de conversa & p.57 & $\begin{array}{l}\text { Seção "Em tom de } \\
\text { conversa" }\end{array}$ \\
\hline & & Roda de conversa & $\begin{array}{l}\text { p.67- } \\
68\end{array}$ & $\begin{array}{l}\text { Seção "Em tom de } \\
\text { conversa" }\end{array}$ \\
\hline & & Debate & $\begin{array}{l}\text { p.68- } \\
69\end{array}$ & $\begin{array}{l}\text { Seção "E mais" (ex. } \\
\text { 3d) }\end{array}$ \\
\hline & $\begin{array}{l}\text { 5-O Modernismo em Portugal e a } \\
\text { poesia de Fernando Pessoa }\end{array}$ & $\begin{array}{l}\text { Peça teatral } \\
\text { Debate }\end{array}$ & $\begin{array}{l}\text { p.86 a } \\
88\end{array}$ & Seção "E mais" \\
\hline & $\begin{array}{l}\text { 6-A segunda geração modernista } \\
\text { brasileira: poesia }\end{array}$ & Roda de discussão & p.93 & Seção "E mais" \\
\hline & \multirow[t]{2}{*}{$\begin{array}{l}\text { 7-A segunda geração modernista } \\
\text { brasileira: prosa }\end{array}$} & Roda de conversa & p.111 & $\begin{array}{l}\text { Seção "Em tom de } \\
\text { conversa" }\end{array}$ \\
\hline & & Debate & p.120 & Seção "E mais" \\
\hline & \multirow[t]{2}{*}{$\begin{array}{l}\text { 8-A terceira geração modernista } \\
\text { brasileira }\end{array}$} & Roda de conversa & p.127 & $\begin{array}{l}\text { Seção "Em tom de } \\
\text { conversa" }\end{array}$ \\
\hline & & Roda de conversa & p.137 & $\begin{array}{l}\text { Seção "E mais" (ex. } \\
\text { 3) }\end{array}$ \\
\hline & \multirow[t]{2}{*}{$\begin{array}{l}\text { 9-Tendências contemporâneas da } \\
\text { literatura de expressão portuguesa }\end{array}$} & Roda de conversa & p.144 & $\begin{array}{l}\text { Seção "Em tom de } \\
\text { conversa" }\end{array}$ \\
\hline & & Roda de discussão & $\begin{array}{l}\text { p.156- } \\
157\end{array}$ & Seção "E mais" \\
\hline & $\begin{array}{l}\text { 10-Tendências contemporâneas da } \\
\text { literatura brasileira }\end{array}$ & Debate & p.167 & Seção "E mais" \\
\hline \multirow{8}{*}{ 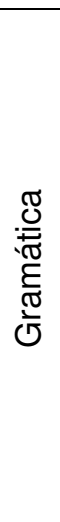 } & $\begin{array}{l}\text { 1-Período composto por subordinação } \\
\text { / Orações subordinadas substantivas }\end{array}$ & ----- & $\begin{array}{l}---- \\
\end{array}$ & ----- \\
\hline & 2-Orações subordinadas adjetivas & ----- & $\begin{array}{ll}---- \\
\end{array}$ & $-\cdots---$ \\
\hline & 3-Orações subordinadas adverbiais & ----- & $\begin{array}{ll}---- \\
\end{array}$ & ----- \\
\hline & $\begin{array}{l}\text { 4-Período composto por coordenação / } \\
\text { Período composto por coordenação e } \\
\text { subordinação }\end{array}$ & Apresentação oral & p.232 & Seção "E mais" \\
\hline & 5-Concordância nominal & $\begin{array}{c}---- \\
\end{array}$ & 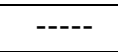 & ----- \\
\hline & 6-Concordância verbal & Roda de discussão & p.269 & $\begin{array}{l}\text { Seção "E mais" (ex. } \\
\text { 3b) }\end{array}$ \\
\hline & 7-Regência verbal / Crase & ----- & ----- & ----- \\
\hline & 8-Colocação pronominal & ----- & ----- & ----- \\
\hline
\end{tabular}




\begin{tabular}{|c|c|c|c|c|}
\hline$\stackrel{\circ}{x}$ & Capítulo & Gênero oral & & Localização \\
\hline \multirow{15}{*}{ 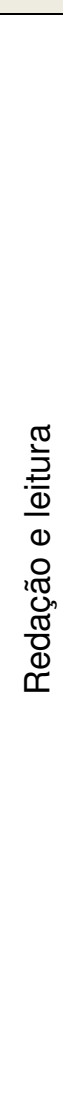 } & \multirow[t]{2}{*}{ 1-O mundo dissertativo } & Roda de conversa & p.310 & $\begin{array}{l}\text { Seção "Em tom de } \\
\text { conversa" }\end{array}$ \\
\hline & & Debate & p.315 & Seção "E mais" \\
\hline & \multirow[t]{3}{*}{$\begin{array}{l}\text { 2-Dissertar e descrever: a delimitação } \\
\text { do tema }\end{array}$} & Roda de conversa & p.319 & $\begin{array}{l}\text { Seção "Em tom de } \\
\text { conversa" }\end{array}$ \\
\hline & & Roda de discussão & $\begin{array}{l}\text { p.321- } \\
322\end{array}$ & Seção "E mais" \\
\hline & & Roda de discussão & p.329 & Seção "E mais" \\
\hline & \multirow{6}{*}{$\begin{array}{l}\text { 3-Dissertar e narrar: assuminc } \\
\text { ponto de vista } \\
\text { 4-A argumentação causal / A } \\
\text { importância dos exemplos }\end{array}$} & Roda de discussão & p.334 & Seção "E mais" \\
\hline & & Roda de conversa & p.342 & $\begin{array}{l}\text { Seção "Em tom de } \\
\text { conversa" }\end{array}$ \\
\hline & & Debate & p.343 & Seção "E mais" \\
\hline & & Roda de conversa & p.347 & $\begin{array}{l}\text { Seção "Em tom de } \\
\text { conversa" }\end{array}$ \\
\hline & & Roda de discussão & p.348 & $\begin{array}{l}\text { Seção "A } \\
\text { importância dos } \\
\text { exemplos" }\end{array}$ \\
\hline & & Roda de conversa & p.349 & $\begin{array}{l}\text { Seção "Em tom de } \\
\text { conversa" }\end{array}$ \\
\hline & \multirow[t]{2}{*}{ 5-A estrutura do texto dissertativo } & Roda de conversa & p.356 & $\begin{array}{l}\text { Seção "Em tom de } \\
\text { conversa" }\end{array}$ \\
\hline & & Roda de discussão & p.357 & Seção "E mais" \\
\hline & 6-Estratégias lógico-expositivas & Debate & $\begin{array}{l}\text { p.379- } \\
380\end{array}$ & Seção "E mais" \\
\hline & 7-Revisão geral & ----- & ----- & ---- \\
\hline
\end{tabular}

(Continuação: Anexo 4c - Gêneros orais em Novas palavras- vol.3) 


\section{ANEXO 5a - Gêneros orais em Português: contexto, interlocução e sentido -} vol.1

\begin{tabular}{|c|c|c|c|c|c|}
\hline$\stackrel{p}{x}$ & .를 & Capítulo & Gênero oral & \multicolumn{2}{|r|}{ Localização } \\
\hline \multirow{25}{*}{ 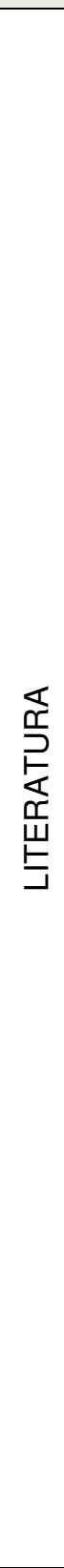 } & \multirow{10}{*}{ 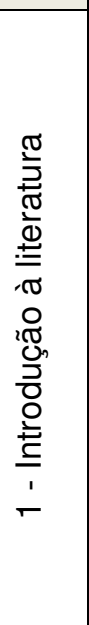 } & \multirow{2}{*}{$\begin{array}{l}\text { 1-Arte literatura e } \\
\text { seus agentes }\end{array}$} & Roda de conversa & p.11 & Seção "Leitura da imagem”. \\
\hline & & & Roda de discussão & p.17 & Seção "Leituras". \\
\hline & & $\begin{array}{l}\text { 2-Literatura é uma } \\
\text { linguagem }\end{array}$ & Roda de conversa & p.24 & Seção "Leitura da imagem" \\
\hline & & 3-Literatura é & Roda de discussão & p.30 & Abertura de capítulo \\
\hline & & gênero I: o épico e & Roda de conversa & p.31 & Seção "Leitura da imagem". \\
\hline & & & Roda de discussão & p.35 & Boxe "Trilha sonora". \\
\hline & & & Roda de discussão & p.40 & Boxe "De olho no filme". \\
\hline & & $\begin{array}{lll}\text { 4-Literatura } & \text { é } \\
\text { gênero II: } & \text { o } \\
\text { dramático } & & \end{array}$ & Roda de conversa & p.46 & Seção "Leitura da imagem". \\
\hline & & 5-Literatura é & Roda de conversa & p.53 & Seção "Leitura da imagem". \\
\hline & & $\begin{array}{l}\text { expressao de uma } \\
\text { época }\end{array}$ & Mesa redonda & p.61 & Seção “Jogo de ideias". \\
\hline & & 6-Literatura & Roda de con & p.65 & Seção "Leitura da imagem". \\
\hline & & Idade Média & $\begin{array}{l}\text { Roda de discussão } \\
\text { Canção }\end{array}$ & p.78 & Seção "Interações" \\
\hline & $\underset{\mathscr{0}}{\mathbb{0}}$ & 7-Humanismo & Roda de conversa & p.80 & Seção "Leitura da imagem". \\
\hline & $\bar{\varpi}$ & & Roda de discussão & p.89 & Seção "Interações" \\
\hline & 을 & 8-Classicismo & Roda de conversa & p.91 & Seção "Leitura da imagem". \\
\hline & $\begin{array}{l}\overline{0} \\
0 \\
\stackrel{D}{\Phi} \\
\Phi\end{array}$ & & $\begin{array}{l}\text { Roda de discussão } \\
\text { Canção }\end{array}$ & p.103 & Seção "Interações" \\
\hline & Oু & & Exposição oral & p.104 & Seção “Jogo de ideias". \\
\hline & $\stackrel{\sim}{N}$ & & $\begin{array}{l}\text { Roda de discussão } \\
\text { Canção }\end{array}$ & p.105 & $\begin{array}{l}\text { Seção "Conexões: encontro de } \\
\text { linguagens" }\end{array}$ \\
\hline & & & Canção & p.106 & $\begin{array}{l}\text { Seção "Conexões: encontro de } \\
\text { linguagens" }\end{array}$ \\
\hline & ㅇ..$\underline{\underline{\sigma}}$ & $\begin{array}{l}\text { 9-Primeiras visões } \\
\text { do Brasil }\end{array}$ & Roda de conversa & p.109 & Seção "Leitura da imagem". \\
\hline & $\stackrel{\widetilde{\sigma}}{=}$ 흐 & 10-Barroco & Roda de conversa & p.120 & Seção "Leitura da imagem". \\
\hline & 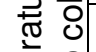 & 11-Arcadismo & Roda de conversa & p.137 & Seção "Leitura da imagem". \\
\hline & $\stackrel{\bar{\Phi}}{ \pm}$ 응 & & Debate & p.154 & Seção "Jogo de ideias". \\
\hline & $\begin{array}{ll}1 \\
1\end{array}$ & & Canção & p.155 & $\begin{array}{l}\text { Seção "Conexões: encontro de } \\
\text { linguagens" }\end{array}$ \\
\hline & & & Canção & p.156 & $\begin{array}{l}\text { Seção "Conexões: encontro de } \\
\text { linguagens" }\end{array}$ \\
\hline
\end{tabular}




\begin{tabular}{|c|c|c|c|c|c|}
\hline$\stackrel{0}{x}$ & 을 & Capítulo & Gênero oral & Loca & ação \\
\hline \multirow{10}{*}{ 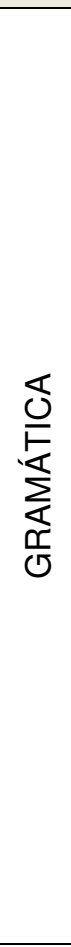 } & \multirow{3}{*}{ 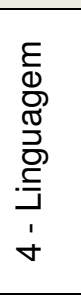 } & $\begin{array}{l}\text { 12-Linguagem e } \\
\text { variação linguística }\end{array}$ & ----- & ----- & ----- \\
\hline & & $\begin{array}{ll}\text { 13-Oralidade } & \mathrm{e} \\
\text { escrita } & \end{array}$ & ----- & ----- & ----- \\
\hline & & $\begin{array}{lr}14-\mathrm{A} & \text { dimensão } \\
\text { discursiva } & \text { da } \\
\text { linguagem } & \end{array}$ & ----- & $\begin{array}{c}---- \\
\end{array}$ & $\begin{array}{c}---- \\
\end{array}$ \\
\hline & \multirow{3}{*}{ 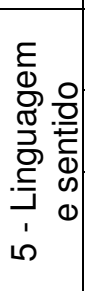 } & $\begin{array}{l}15-A \text { construção do } \\
\text { sentido }\end{array}$ & ----- & ----- & ----- \\
\hline & & $\begin{array}{l}\text { 16-Efeitos de } \\
\text { sentido }\end{array}$ & ---- & ---- & $\begin{array}{c}---- \\
-1\end{array}$ \\
\hline & & $\begin{array}{l}\text { 17-Recursos } \\
\text { estilísticos: figuras } \\
\text { de linguagem }\end{array}$ & ----- & ----- & ----- \\
\hline & \multirow{4}{*}{ 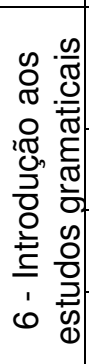 } & $\begin{array}{l}\text { 18-A gramática } \mathrm{e} \\
\text { suas partes }\end{array}$ & ----- & $\begin{array}{c}---- \\
-1\end{array}$ & $\begin{array}{c}---- \\
-1\end{array}$ \\
\hline & & $\begin{array}{l}\text { 19-A estrutura das } \\
\text { palavras }\end{array}$ & $-\cdots--$ & ---- & 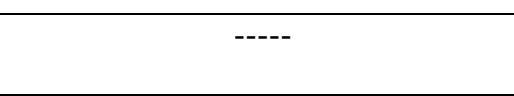 \\
\hline & & $\begin{array}{l}\text { 20-Formação de } \\
\text { palavras I }\end{array}$ & ----- & ----- & ----- \\
\hline & & $\begin{array}{l}\text { 21-Formação de } \\
\text { palavras II }\end{array}$ & ----- & $\begin{array}{c}---- \\
\end{array}$ & $\begin{array}{c}---- \\
\end{array}$ \\
\hline \multirow{15}{*}{ 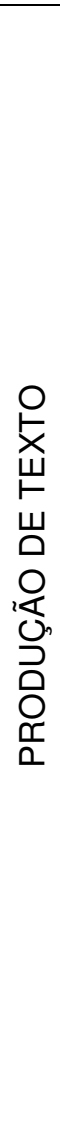 } & \multirow{5}{*}{ 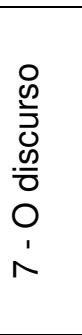 } & 22-Discurso e texto & $\begin{array}{l}\text { Roda de discussão } \\
\text { Canção }\end{array}$ & p.280 & Seção "Sugestão de trabalho" \\
\hline & & & Roda de discussão & p.282 & Seção "De olho no filme" \\
\hline & & & Apresentação oral & p.282 & Seção "Sugestão de trabalho" \\
\hline & & $\begin{array}{l}\text { 23-A interlocução e } \\
\text { o contexto }\end{array}$ & Roda de discussão & p.301 & Seção "Procedimentos" \\
\hline & & $\begin{array}{l}\text { 24-Os gêneros do } \\
\text { discurso }\end{array}$ & ----- & $\begin{array}{c}---- \\
\end{array}$ & $\begin{array}{c}---- \\
\end{array}$ \\
\hline & \multirow{4}{*}{ 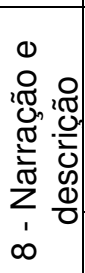 } & \multirow{3}{*}{$\begin{array}{l}\text { 25-Relato, carta } \\
\text { pessoal, e-mail e } \\
\text { diário }\end{array}$} & Debate & p.328 & Seção "De olho no filme". \\
\hline & & & Relato oral & p.335 & Seção "Sugestão de trabalho" \\
\hline & & & Canção & p.393 & $\begin{array}{l}\text { Seção "Conexões: encontro de } \\
\text { linguagens" }\end{array}$ \\
\hline & & 26-Notícia & $\begin{array}{ll}---- \\
--1\end{array}$ & $\begin{array}{ll}---- \\
\end{array}$ & $\begin{array}{ll}---- \\
\end{array}$ \\
\hline & \multirow{3}{*}{ 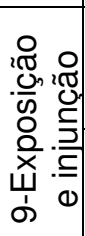 } & 27-Reportagem & ----- & ----- & ----- \\
\hline & & & & & \\
\hline & & $\begin{array}{l}\text { 28-Textos } \\
\text { instrucionais }\end{array}$ & Canção & p.396 & $\begin{array}{l}\text { Seção "Conexões: encontro de } \\
\text { linguagens" }\end{array}$ \\
\hline & \multirow{3}{*}{ 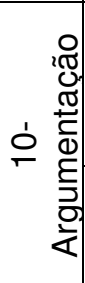 } & \multirow{2}{*}{$\begin{array}{l}\text { 29-Textos } \\
\text { publicitários }\end{array}$} & Spot de rádio & p.372 & Boxe "Produção oral" \\
\hline & & & Debate & p.378 & Boxe "Produção oral" \\
\hline & & 30-Resenha & $\begin{array}{c}---- \\
\end{array}$ & $\begin{array}{c}---- \\
\end{array}$ & $\begin{array}{c}---- \\
\end{array}$ \\
\hline
\end{tabular}

(Continuação: Anexo 5a - Gêneros orais em Português: contexto, interlocução e sentido - vol.1) 


\section{ANEXO 5b - Gêneros orais em Português: contexto, interlocução e sentido -} vol.2

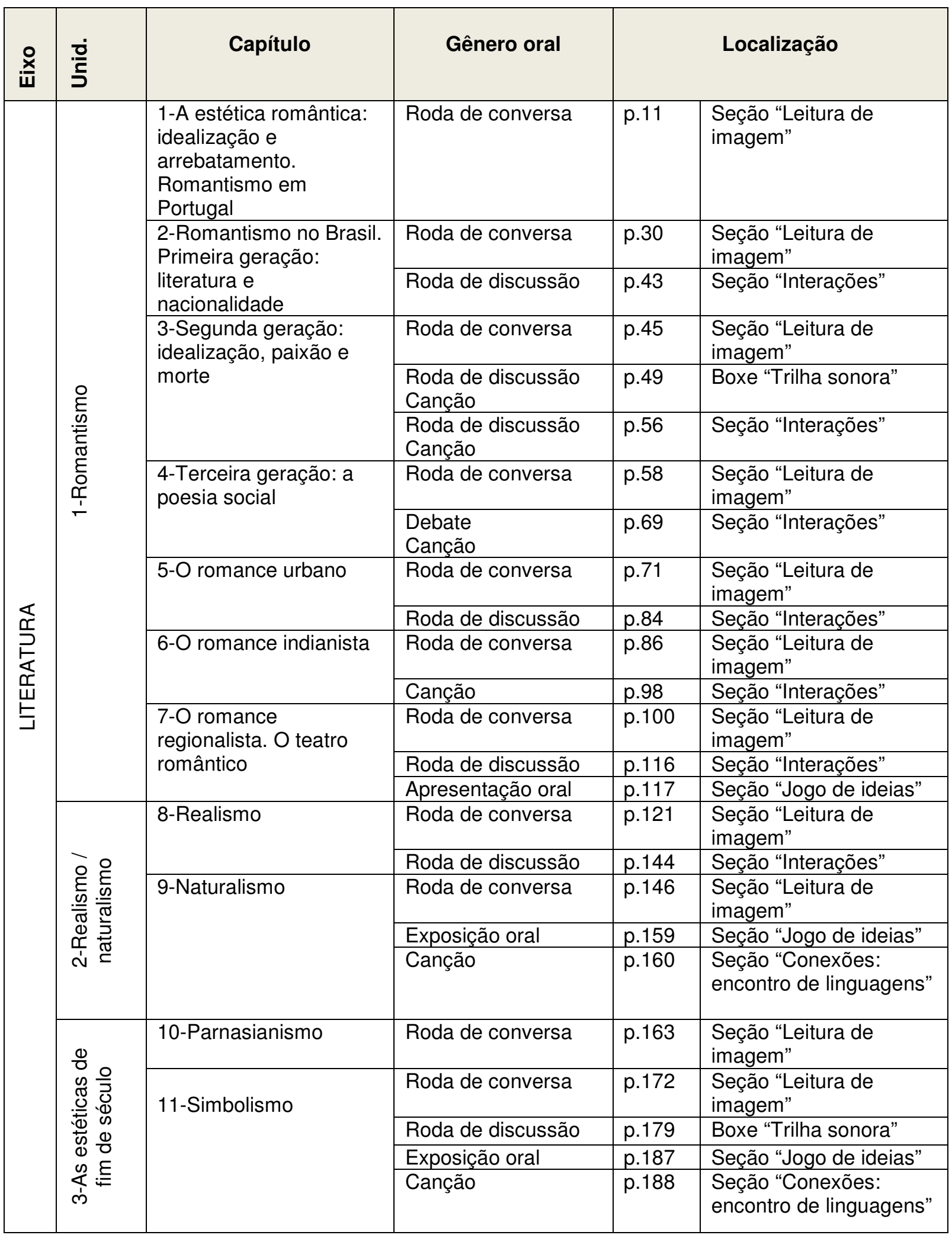




\begin{tabular}{|c|c|c|c|c|c|}
\hline$\stackrel{0}{x}$ & .ृ一 & Capítulo & Gênero oral & & Localização \\
\hline \multirow{12}{*}{ 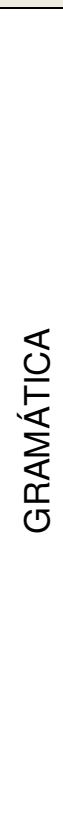 } & \multirow{10}{*}{ 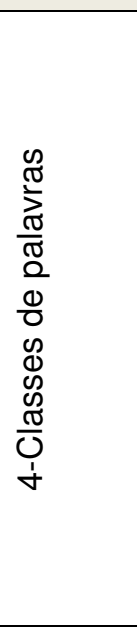 } & $\begin{array}{l}\text { 12-Relações } \\
\text { morfossintáticas }\end{array}$ & ---- & $-\cdots$ & ----- \\
\hline & & 13-Substantivo & ---- & ---- & ----- \\
\hline & & 14-Adjetivo & ----- & $\overline{-----}$ & $\begin{array}{ll}---- \\
\end{array}$ \\
\hline & & 15-Pronome I & $\begin{array}{c}---- \\
-\end{array}$ & $\begin{array}{cl}---- \\
\end{array}$ & ----- \\
\hline & & 16-Pronome II & ---- & ---- & ----- \\
\hline & & $\begin{array}{l}\text { 17-Artigo, numeral e } \\
\text { interjeição }\end{array}$ & ----- & ----- & ----- \\
\hline & & 18-Verbo I & $\begin{array}{ll}---- \\
-\end{array}$ & $---{ }_{-}$ & $-\cdots--$ \\
\hline & & 19-Verbo II & $\begin{array}{ll}---- \\
\end{array}$ & $\begin{array}{cl}---- \\
\end{array}$ & ----- \\
\hline & & 20-Advérbio & ---- & ---- & ----- \\
\hline & & $\begin{array}{l}\text { 21-Preposição e } \\
\text { conjunção }\end{array}$ & ----- & $\begin{array}{c}---- \\
\end{array}$ & $\begin{array}{ll}----- \\
\end{array}$ \\
\hline & \multirow{2}{*}{ 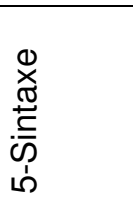 } & $\begin{array}{l}\text { 22-Introdução ao estudo } \\
\text { da sintaxe }\end{array}$ & ----- & $\begin{array}{ll}---- \\
\end{array}$ & $\begin{array}{ll}---- \\
\end{array}$ \\
\hline & & $\begin{array}{l}\text { 23-Sintaxe do período } \\
\text { simples }\end{array}$ & ----- & ---- & ----- \\
\hline \multirow{5}{*}{ 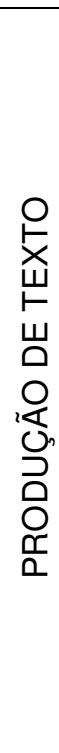 } & \multirow{2}{*}{ 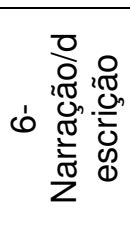 } & \multirow[t]{2}{*}{ 24-Crônica } & Canção & p.359 & Boxe "Produção oral" \\
\hline & & & Canção & p.396 & $\begin{array}{l}\text { Seção "Conexões: } \\
\text { encontro de linguagens" }\end{array}$ \\
\hline & 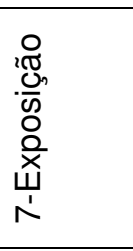 & 25-Texto enciclopédico & Canção & p.397 & $\begin{array}{l}\text { Seção "Conexões: } \\
\text { encontro de linguagens" }\end{array}$ \\
\hline & \multirow{2}{*}{ 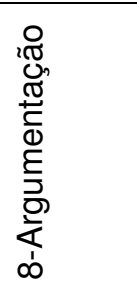 } & 26-Carta aberta & ----- & $\begin{array}{ll}---- \\
\end{array}$ & $\begin{array}{ll}---- \\
\end{array}$ \\
\hline & & $\begin{array}{l}\text { 27-Artigo de opinião e } \\
\text { editorial }\end{array}$ & Debate & p.396 & $\begin{array}{l}\text { Seção "Conexões: } \\
\text { encontro de linguagens" }\end{array}$ \\
\hline
\end{tabular}

(Continuação: Anexo 5b - Gêneros orais em Português: contexto, interlocução e sentido - vol.2) 
ANEXO 5c - Gêneros orais em Português: contexto, interlocução e sentidovol.3

\begin{tabular}{|c|c|c|c|c|c|}
\hline & & Capítulo & Gênero oral & & Localização \\
\hline \multirow{18}{*}{ 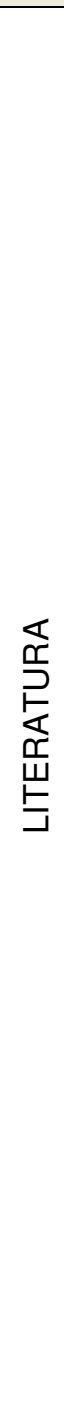 } & \multirow{9}{*}{ 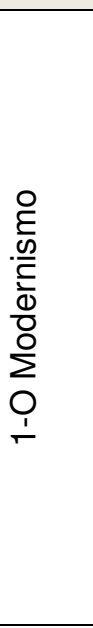 } & 1-Pré-Modernismo & Roda de conversa & p.11 & $\begin{array}{l}\text { Seção "Leitura de } \\
\text { imagem" }\end{array}$ \\
\hline & & \multirow{2}{*}{$\begin{array}{l}\text { 2-Vanguardas culturais } \\
\text { europeias. Modernismo } \\
\text { em Portugal }\end{array}$} & Roda de conversa & p.28 & $\begin{array}{l}\text { Seção "Leitura de } \\
\text { imagem" }\end{array}$ \\
\hline & & & Roda de discussão & p.54 & Seção "Interações" \\
\hline & & \multirow{2}{*}{$\begin{array}{l}\text { 3-Modernismo no Brasil. } \\
\text { Primeira geração: ousadia } \\
\text { e inovação }\end{array}$} & Roda de conversa & p.56 & $\begin{array}{l}\text { Seção "Leitura de } \\
\text { imagem" }\end{array}$ \\
\hline & & & Roda de discussão & p.74 & Seção "Interações" \\
\hline & & $\begin{array}{l}\text { 4-Segunda geração: } \\
\text { misticismo e consciência } \\
\text { social }\end{array}$ & Roda de conversa & p.76 & $\begin{array}{l}\text { Seção "Leitura de } \\
\text { imagem" }\end{array}$ \\
\hline & & $5-0$ romance de 1930 & Roda de conversa & p.95 & $\begin{array}{l}\text { Seção "Leitura de } \\
\text { imagem" }\end{array}$ \\
\hline & & & Roda de discussão & p.110 & Seção "Interações" \\
\hline & & & Apresentação oral & p.111 & Seção "Jogo de ideias" \\
\hline & \multirow{7}{*}{ 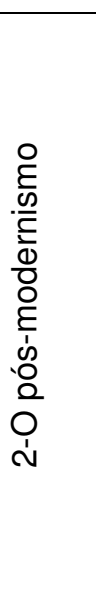 } & \multirow[t]{3}{*}{$\begin{array}{l}\text { 6-A geração de } 1945 \text { e o } \\
\text { Concretismo }\end{array}$} & Roda de conversa & p.115 & $\begin{array}{l}\text { Seção "Leitura de } \\
\text { imagem" }\end{array}$ \\
\hline & & & Roda de discussão & p.130 & Seção "Interações" \\
\hline & & & Canção & p.171 & $\begin{array}{l}\text { Seção "Seção } \\
\text { "Conexões: encontro de } \\
\text { linguagens"”" }\end{array}$ \\
\hline & & \multirow[t]{2}{*}{ 7-A prosa pós-moderna } & Roda de conversa & p.132 & $\begin{array}{l}\text { Seção "Leitura de } \\
\text { imagem" }\end{array}$ \\
\hline & & & Roda de discussão & p.145 & Seção "Interações" \\
\hline & & \multirow{2}{*}{$\begin{array}{l}\text { 8-Tendências } \\
\text { contemporâneas. O teatro } \\
\text { no século XX }\end{array}$} & Roda de conversa & p.147 & $\begin{array}{l}\text { Seção "Leitura de } \\
\text { imagem" }\end{array}$ \\
\hline & & & Canção & p.172 & $\begin{array}{l}\text { Seção "Seção } \\
\text { "Conexões: encontro de } \\
\text { linguagens"”" }\end{array}$ \\
\hline & \multirow{2}{*}{ 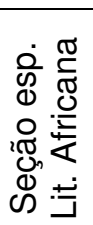 } & $\begin{array}{l}\text { A poesia africana de } \\
\text { Língua Portuguesa }\end{array}$ & ----- & ----- & ----- \\
\hline & & $\begin{array}{l}\text { A narrativa africana de } \\
\text { Língua Portuguesa }\end{array}$ & Canção & p.204 & $\begin{array}{l}\text { Seção "Seção } \\
\text { "Conexões: encontro de } \\
\text { linguagens"” }\end{array}$ \\
\hline
\end{tabular}




\begin{tabular}{|c|c|c|c|c|c|}
\hline 임 & :o & Capítulo & Gênero oral & & Localização \\
\hline \multirow{8}{*}{ 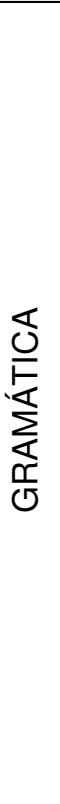 } & \multirow{4}{*}{ 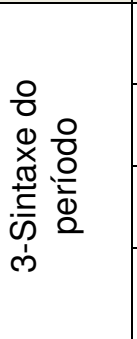 } & $\begin{array}{l}\text { 9-O estudo do período } \\
\text { composto }\end{array}$ & ----- & ----- & ----- \\
\hline & & $\begin{array}{l}\text { 10-Período composto } \\
\text { por coordenação }\end{array}$ & ----- & $\begin{array}{l}---- \\
\end{array}$ & ----- \\
\hline & & $\begin{array}{l}\text { 11-Período composto } \\
\text { por subordinação I }\end{array}$ & ----- & $\begin{array}{l}---- \\
-1\end{array}$ & ----- \\
\hline & & $\begin{array}{l}\text { 12- Período composto } \\
\text { por subordinação II }\end{array}$ & ----- & ----- & ----- \\
\hline & \multirow{2}{*}{ 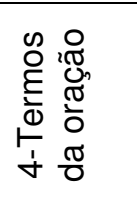 } & $\begin{array}{l}\text { 13-Concordância e } \\
\text { regência }\end{array}$ & ----- & ----- & ----- \\
\hline & & $\begin{array}{l}\text { 14-Colocação } \\
\text { pronominal }\end{array}$ & ----- & ----- & ---- \\
\hline & \multirow{2}{*}{ 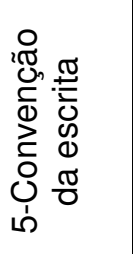 } & $15-A$ crase e seu uso & ----- & $-\cdots--$ & ---- \\
\hline & & 16-Pontuação & ----- & ----- & $\begin{array}{l}---- \\
\end{array}$ \\
\hline \multirow{6}{*}{ 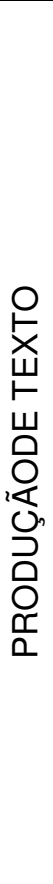 } & \multirow{2}{*}{ 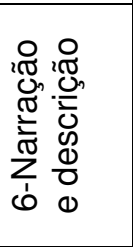 } & 17-Biografia & Canção & p.395 & $\begin{array}{l}\text { Seção "Seção } \\
\text { "Conexões: encontro de } \\
\text { linguagens"”" }\end{array}$ \\
\hline & & 18-Conto & Canção & p.396 & $\begin{array}{l}\text { Seção "Seção } \\
\text { "Conexões: encontro de } \\
\text { linguagens"”" }\end{array}$ \\
\hline & \multirow{2}{*}{ 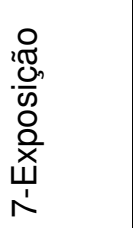 } & $\begin{array}{l}\text { 19-Texto de divulgação } \\
\text { científica }\end{array}$ & ----- & ---- & ---- \\
\hline & & 20-Relatório & $\begin{array}{l}---- \\
\end{array}$ & $\begin{array}{l}---- \\
-1\end{array}$ & ----- \\
\hline & \multirow{2}{*}{ 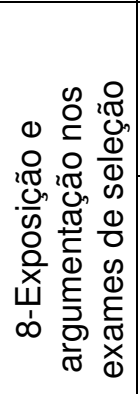 } & $\begin{array}{l}\text { 21-Texto dissertativo- } \\
\text { argumentativo I }\end{array}$ & $\begin{array}{l}---- \\
\end{array}$ & ----- & ----- \\
\hline & & $\begin{array}{l}\text { 22-Texto dissertativo- } \\
\text { argumentativo II: } \\
\text { elaboração de um } \\
\text { projeto }\end{array}$ & ----- & ----- & ----- \\
\hline
\end{tabular}

(Continuação: Anexo 5c - Gêneros orais em Português: contexto, interlocução e sentido - vol.3) 
ANEXO 6a - Gêneros orais em Língua Portuguesa: linguagem e interação vol.1

\begin{tabular}{|c|c|c|c|c|}
\hline$\frac{\text { o }}{\underline{s}}$ & Capítulo & Gênero oral & & Localização \\
\hline- & $\begin{array}{l}\text { Linguagens, textos e } \\
\text { literatura }\end{array}$ & Roda de conversa & p.9 & $\begin{array}{l}\text { Introdução do capítulo que } \\
\text { inicia o livro }\end{array}$ \\
\hline \multirow{6}{*}{ 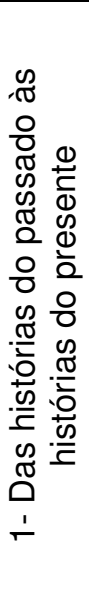 } & Abertura da Unidade & Roda de conversa & p.20-21 & $\begin{array}{l}\text { Seção "Para começo de } \\
\text { conversa" }\end{array}$ \\
\hline & 1- Conto & $\begin{array}{l}\text { Conto de fada } \\
\text { Conto maravilhoso }\end{array}$ & p.36 & Seção "Linguagem oral" \\
\hline & \multirow[t]{2}{*}{ 2- Novela } & Roda de conversa & p.64 & $\begin{array}{l}\text { Seção "Literatura: teoria e } \\
\text { história". Ex. } 16\end{array}$ \\
\hline & & $\begin{array}{l}\text { Lenda; mito; } \\
\text { parlenda; anedota; } \\
\text { máxima; provérbio; } \\
\text { conto de fada; } \\
\text { conto maravilhoso; } \\
\text { xácara; romance }\end{array}$ & p.65-66 & Seção “Linguagem oral” \\
\hline & \multirow[t]{2}{*}{ 3- Crônica } & Lenda urbana & p.85-90 & Seção "Linguagem oral" \\
\hline & & $\begin{array}{l}\text { Peça teatral } \\
\text { Telenovela }\end{array}$ & p.96-97 & $\begin{array}{l}\text { Seção "E a conversa chega } \\
\text { ao fim" }\end{array}$ \\
\hline \multirow{7}{*}{ 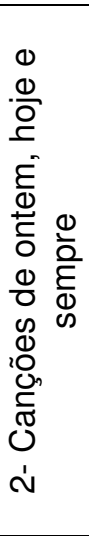 } & Abertura da Unidade & Roda de conversa & p.99 & $\begin{array}{l}\text { Seção "Para começo de } \\
\text { conversa". Item c }\end{array}$ \\
\hline & \multirow[t]{2}{*}{ 4- Narrativa histórica } & Roda de discussão & p.103 & $\begin{array}{l}\text { Seção "Para entender o } \\
\text { texto". Ex.8 }\end{array}$ \\
\hline & & Roda de conversa & p.114-117 & $\begin{array}{l}\text { Seção "Linguagem oral". } \\
\text { Ex. } 1,2 \text { e } 3 \text {. }\end{array}$ \\
\hline & \multirow[t]{3}{*}{ 5- Canção popular } & $\begin{array}{l}\text { Canção } \\
\text { Roda de discussão }\end{array}$ & p.134 & $\begin{array}{l}\text { Seção "Para entender os } \\
\text { textos". Ex.7 }\end{array}$ \\
\hline & & Discurso político & p.148 & $\begin{array}{l}\text { Seção "Linguagem oral". } \\
\text { Ex.3 }\end{array}$ \\
\hline & & Canção & p.156 & $\begin{array}{l}\text { Seção "Produção escrita". } \\
\text { Item F }\end{array}$ \\
\hline & 6- Textos icônico-verbais & Canção & p.181 & Seção “Agora é com você!” \\
\hline \multirow{7}{*}{ 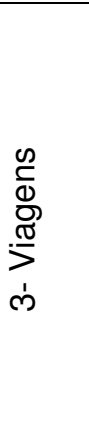 } & Abertura da Unidade & Roda de conversa & p.184 & $\begin{array}{l}\text { Seção "Para começo de } \\
\text { conversa". Item c }\end{array}$ \\
\hline & \multirow[t]{2}{*}{ 7- Relato de viagem } & Exposição oral & p.204-205 & Seção "Linguagem oral" \\
\hline & & $\begin{array}{l}\text { Exposição oral } \\
\text { Roda de discussão }\end{array}$ & p.215 & $\begin{array}{l}\text { Seção "Para ir mais longe". } \\
\text { Ex. b / c }\end{array}$ \\
\hline & \multirow[t]{2}{*}{ 8- Diário pessoal } & Exposição oral & p.229-230 & Seção "Linguagem oral" \\
\hline & & Roda de discussão & p.235 & $\begin{array}{l}\text { Seção "Para ir mais longe" } \\
\text { Ex. } 2\end{array}$ \\
\hline & \multirow[t]{2}{*}{ 9- Notícia } & Exposição oral & p.246-247 & Seção "Linguagem oral" \\
\hline & & Canção & p.257 & Seção "Agora é com você!" \\
\hline \multirow{7}{*}{ 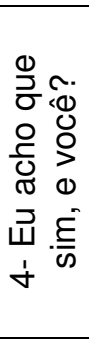 } & Abertura da Unidade & ----- & $-\cdots---$ & ----- \\
\hline & 10- Artigo de opinião & Debate & p.279-280 & Seção "Linguagem oral" \\
\hline & \multirow[t]{2}{*}{ 11- Editorial } & Debate & p.302 & Seção "Linguagem oral" \\
\hline & & Sermão & p.309 & Seção "Para ir mais longe" \\
\hline & \multirow[t]{3}{*}{ 12- Carta do leitor } & Roda de discussão & p.311 & $\begin{array}{l}\text { Seção "Para entender o } \\
\text { texto". Ex. } 6\end{array}$ \\
\hline & & Debate & p.326-329 & Seção "Linguagem oral" \\
\hline & & Canção & p.335 & Seção "Agora é com você" \\
\hline
\end{tabular}




\section{ANEXO 6b - Gêneros orais em Língua Portuguesa: linguagem e interação- vol.2}

\begin{tabular}{|c|c|c|c|c|}
\hline 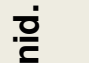 & Capítulo & Gênero oral & & Localização \\
\hline- & $\begin{array}{l}\text { Textos, coesão e } \\
\text { coerência }\end{array}$ & ----- & ----- & ----- \\
\hline \multirow{9}{*}{ 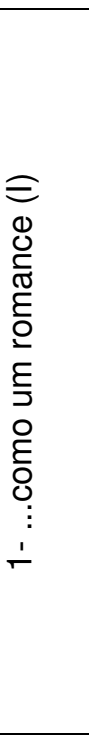 } & Abertura da Unidade & Roda de conversa & p.15 & $\begin{array}{l}\text { Seção "Para começo de } \\
\text { conversa". Ex. 1, } 2 \text { e } 3\end{array}$ \\
\hline & \multirow[t]{2}{*}{ 1- Romance (I) } & $\begin{array}{l}\text { Conversa cotidiana } \\
\text { Debate regrado }\end{array}$ & p. 37 & $\begin{array}{l}\text { Seção "Linguagem oral". } \\
\text { Item c }\end{array}$ \\
\hline & & $\begin{array}{l}\text { Conversa cotidiana } \\
\text { Debate televisivo }\end{array}$ & p.49 & Seção "Para ir mais longe" \\
\hline & \multirow[t]{2}{*}{ 2- Romance (II) } & Roda de conversa & p.62 & $\begin{array}{l}\text { Seção "Literatura: teoria e } \\
\text { história". Ex.11 }\end{array}$ \\
\hline & & $\begin{array}{l}\text { Entrevista } \\
\text { Conversa telefônica }\end{array}$ & p.67-69 & Seção "Linguagem oral" \\
\hline & \multirow[t]{4}{*}{$\begin{array}{l}\text { 3- Suspense na } \\
\text { narrativa }\end{array}$} & $\begin{array}{l}\text { Conto } \\
\text { Peça teatral }\end{array}$ & p.99 & Seção "Linguagem oral" \\
\hline & & Peça teatral & p.107 & $\begin{array}{l}\text { Seção "Para ir mais longe". } \\
\text { Ex. 3b. }\end{array}$ \\
\hline & & Canção & p.109 & Secão "Agora é com você!" \\
\hline & & Roda de discussão & p.111 & $\begin{array}{l}\text { Seção "E a conversa chega } \\
\text { ao fim". Ex. } 2 .\end{array}$ \\
\hline \multirow{4}{*}{ 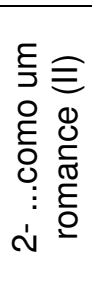 } & Abertura da Unidade & ----- & ----- & ---- \\
\hline & 4- Romance (III) & Conversa telefônica & p.126 & Seção "Linguagem oral" \\
\hline & 5- Romance (IV) & --.-- & --.-- & ----- \\
\hline & 6- Texto instrucional & ----- & ----- & ----- \\
\hline \multirow{7}{*}{ 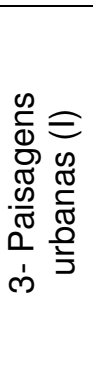 } & Abertura da Unidade & ----- & ----- & ---- \\
\hline & 7- Artigo científico & Entrevista oral & p.210 & Seção "Linguagem oral" \\
\hline & \multirow[t]{2}{*}{$\begin{array}{l}\text { 8- Texto de vulgarização } \\
\text { científica }\end{array}$} & Roda de discussão & p. 228 & $\begin{array}{l}\text { Seção "Literatura: teoria e } \\
\text { história" }\end{array}$ \\
\hline & & Entrevista oral & p.229-230 & Seção "Linguagem oral" \\
\hline & \multirow[t]{3}{*}{ 9- Reportagem } & Exposição oral & p.240 & $\begin{array}{l}\text { Seção "Para entender o } \\
\text { texto" }\end{array}$ \\
\hline & & Entrevista oral & p.252-253 & Seção "Linguagem oral" \\
\hline & & Roda de conversa & p.260 & Seção "Para ir mais longe" \\
\hline \multirow{8}{*}{ 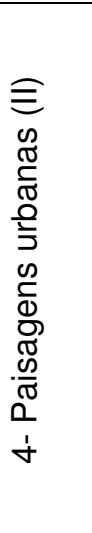 } & Abertura da Unidade & $\begin{array}{l}\text { Canção } \\
\text { Roda de discussão }\end{array}$ & p.266-267 & $\begin{array}{l}\text { Seção "Para começo de } \\
\text { conversa" }\end{array}$ \\
\hline & 10- Ensaio & ----- & $\begin{array}{ll}---- \\
\end{array}$ & $\begin{array}{c}---- \\
\end{array}$ \\
\hline & \multirow[t]{3}{*}{$\begin{array}{l}\text { 11- Imagem e palavra } \\
\text { (I): anúncio publicitário }\end{array}$} & Roda de conversa & p.299 & $\begin{array}{l}\text { Seção "Literatura: teoria e } \\
\text { história" }\end{array}$ \\
\hline & & $\begin{array}{l}\text { Exposição oral } \\
\text { Roda de discussão }\end{array}$ & p.304 & Seção "Linguagem oral" \\
\hline & & Exposição oral & p.311 & Seção "Para ir mais longe" \\
\hline & \multirow{3}{*}{$\begin{array}{l}\text { 12- Imagem e palavra } \\
\text { (II): desenho de } \\
\text { imprensa }\end{array}$} & Roda de conversa & p.314 & $\begin{array}{l}\text { Seção "Para entender os } \\
\text { textos". Ex.3f }\end{array}$ \\
\hline & & Exposição oral & p.325 & Seção "Linguagem oral" \\
\hline & & Exposição oral & p.337 & $\begin{array}{l}\text { Seção "E a conversa chega } \\
\text { ao fim". Ex. } 3 .\end{array}$ \\
\hline
\end{tabular}


ANEXO 6c - Gêneros orais em Língua Portuguesa: linguagem e interaçãovol.3

\begin{tabular}{|c|c|c|c|c|}
\hline 을 & Capítulo & Gênero oral & & Localização \\
\hline- & $\begin{array}{l}\text { Os textos e os graus de } \\
\text { formalidade da linguagem }\end{array}$ & $\begin{array}{l}---- \\
\end{array}$ & $\begin{array}{l}---- \\
\end{array}$ & ----- \\
\hline \multirow{9}{*}{ 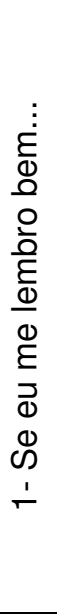 } & Abertura da Unidade & ----- & ----- & ---- \\
\hline & 1- Relato mítico & Exposição oral & p.34 & $\begin{array}{l}\text { Seção "Literatura: teoria e } \\
\text { história" }\end{array}$ \\
\hline & \multirow[t]{4}{*}{ 2- Lenda } & Roda de conversa & p.60 & $\begin{array}{l}\text { Seção "Literatura: teoria e } \\
\text { história" }\end{array}$ \\
\hline & & Aula & p.61 & Seção "Linguagem oral" \\
\hline & & $\begin{array}{l}\text { Exposição oral } \\
\text { Entrevista } \\
\text { Debate }\end{array}$ & p.65 & $\begin{array}{l}\text { Seção "Prática de } \\
\text { linguagem" }\end{array}$ \\
\hline & & $\begin{array}{l}\text { Lenda } \\
\text { Roda de discussão }\end{array}$ & p.66 & Seção "Produção escrita" \\
\hline & \multirow[t]{3}{*}{ 3- Memórias } & Roda de conversa & p.70 & Seção "Gramática textual" \\
\hline & & Roda de discussão & p.75 & Seção "Linguagem oral” \\
\hline & & Canção & p.95 & $\begin{array}{l}\text { Seção "Agora é com } \\
\text { você!" }\end{array}$ \\
\hline \multirow{10}{*}{ 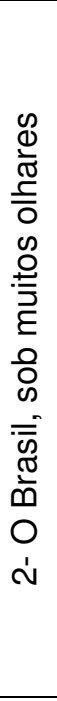 } & Abertura da Unidade & Roda de conversa & p.99 & $\begin{array}{l}\text { Seção "Para começo de } \\
\text { conversa" }\end{array}$ \\
\hline & \multirow[t]{3}{*}{ 4- Canções } & Canção & p.105 & $\begin{array}{l}\text { Seção "Gramática } \\
\text { textual". Ex. } 6\end{array}$ \\
\hline & & $\begin{array}{l}\text { Conto } \\
\text { Roda de discussão }\end{array}$ & p.111 & Seção "Linguagem oral" \\
\hline & & Canção & p.117 & Seção "Produção escrita" \\
\hline & 5- Micro-histórias & ---- & ---- & ---- \\
\hline & \multirow[t]{5}{*}{ 6- Gêneros dramáticos } & $\begin{array}{l}\text { Peça teatral } \\
\text { Exposição oral }\end{array}$ & p.155-156 & $\begin{array}{l}\text { Seção "Literatura: teoria e } \\
\text { história". Ex. } 13 \text { e } 14\end{array}$ \\
\hline & & Telenovela & p.156 & Seção "Linguagem oral" \\
\hline & & $\begin{array}{l}\text { Roda de conversa } \\
\text { Conto }\end{array}$ & p.162-163 & $\begin{array}{l}\text { Seção "Produção escrita". } \\
\text { Ex. } 3 \text { e } 5\end{array}$ \\
\hline & & Exposição oral & p.165 & $\begin{array}{l}\text { Seção "Para ir mais } \\
\text { longel". Ex. 2c }\end{array}$ \\
\hline & & Canção & p.167 & $\begin{array}{l}\text { Seção "Agora é com } \\
\text { você!" }\end{array}$ \\
\hline \multirow{7}{*}{ 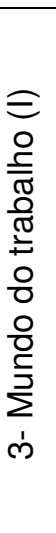 } & Abertura da Unidade & Roda de discussão & p.171 & $\begin{array}{l}\text { Seção "Para começo de } \\
\text { conversa" }\end{array}$ \\
\hline & $\begin{array}{l}\text { 7- Biografias e relatos de } \\
\text { vida }\end{array}$ & $\begin{array}{l}\text { Telejornal } \\
\text { Propaganda (rádio) } \\
\text { Conversa telefônica }\end{array}$ & p.188 & Seção "Linguagem oral" \\
\hline & 8- Carta pessoal & Roda de discussão & p.218 & Seção "Linguagem oral" \\
\hline & \multirow[t]{4}{*}{$\begin{array}{l}\text { 9- Entrevista concedida } \\
\text { por especialista }\end{array}$} & $\begin{array}{l}\text { Entrevista } \\
\text { (transcrição) }\end{array}$ & p.230-235 & $\begin{array}{l}\text { Seção "Texto 1"; "Para } \\
\text { entender o texto"; "As } \\
\text { palavras no contexto" }\end{array}$ \\
\hline & & Conversa telefônica & p.246-247 & Seção "Linguagem oral" \\
\hline & & Entrevista & p.251 & Seção "Produção escrita" \\
\hline & & Roda de conversa & p.257 & $\begin{array}{l}\text { Seção "E a conversa } \\
\text { chega ao fim". Ex.2 }\end{array}$ \\
\hline
\end{tabular}




\begin{tabular}{|c|c|c|c|c|}
\hline$\frac{7}{2}$ & Capítulo & Gênero oral & & Localização \\
\hline \multirow{9}{*}{ 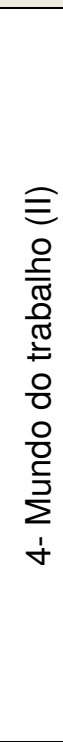 } & Abertura da Unidade & Roda de discussão & p.261 & $\begin{array}{l}\text { Seção "Para começo de } \\
\text { conversa" }\end{array}$ \\
\hline & $\begin{array}{l}\text { 10- Correspondência } \\
\text { formal argumentativa }\end{array}$ & $\begin{array}{l}\text { Mesa redonda } \\
\text { Exposição oral } \\
\text { Debate regrado }\end{array}$ & p.280-281 & Seção "Linguagem oral" \\
\hline & \multirow[t]{2}{*}{ 11- Dissertação em prosa } & Roda de conversa & p.290 & $\begin{array}{l}\text { Seção "Para entender o } \\
\text { texto" }\end{array}$ \\
\hline & & $\begin{array}{l}\text { Mesa redonda } \\
\text { Exposição oral } \\
\text { Debate regrado }\end{array}$ & p.314-315 & Seção "Linguagem oral" \\
\hline & \multirow[t]{5}{*}{ 12- Discurso político } & Roda de discussão & p.323 & $\begin{array}{l}\text { Seção "Para começo de } \\
\text { conversa" }\end{array}$ \\
\hline & & Mesa redonda & p.347 & Seção "Linguagem oral" \\
\hline & & $\begin{array}{l}\text { Debate } \\
\text { Mesa redonda }\end{array}$ & p.351 & $\begin{array}{l}\text { Seção "Para ir mais } \\
\text { longel" }\end{array}$ \\
\hline & & Canção & p.353 & Seção "Agora é com você! \\
\hline & & Mesa redonda & p.355 & $\begin{array}{l}\text { Seção "E a conversa } \\
\text { chega ao fim" }\end{array}$ \\
\hline
\end{tabular}

(Continuação: Anexo 6c - Gêneros orais em Língua Portuguesa: linguagem e interação - vol.3) 